\title{
$I-1527$
}

$2^{23}$ SANDIA REPORT SAND82-0309・ Unlimited Release

Printed January 1982

$$
\text { CONF-820218--(absts) }
$$

\section{Photovoltaic Systems and Applications}

Third Project Integration Meeting Albuquerque, New Mexico

February 9, 10, 11, 1982

Prepared by

Sandia National Laboratories

Albuquerque, New Mexico 87185 and Livermore, California 94550

for the United States Department of Energy

f under Contract DE-AC04-76DP00789

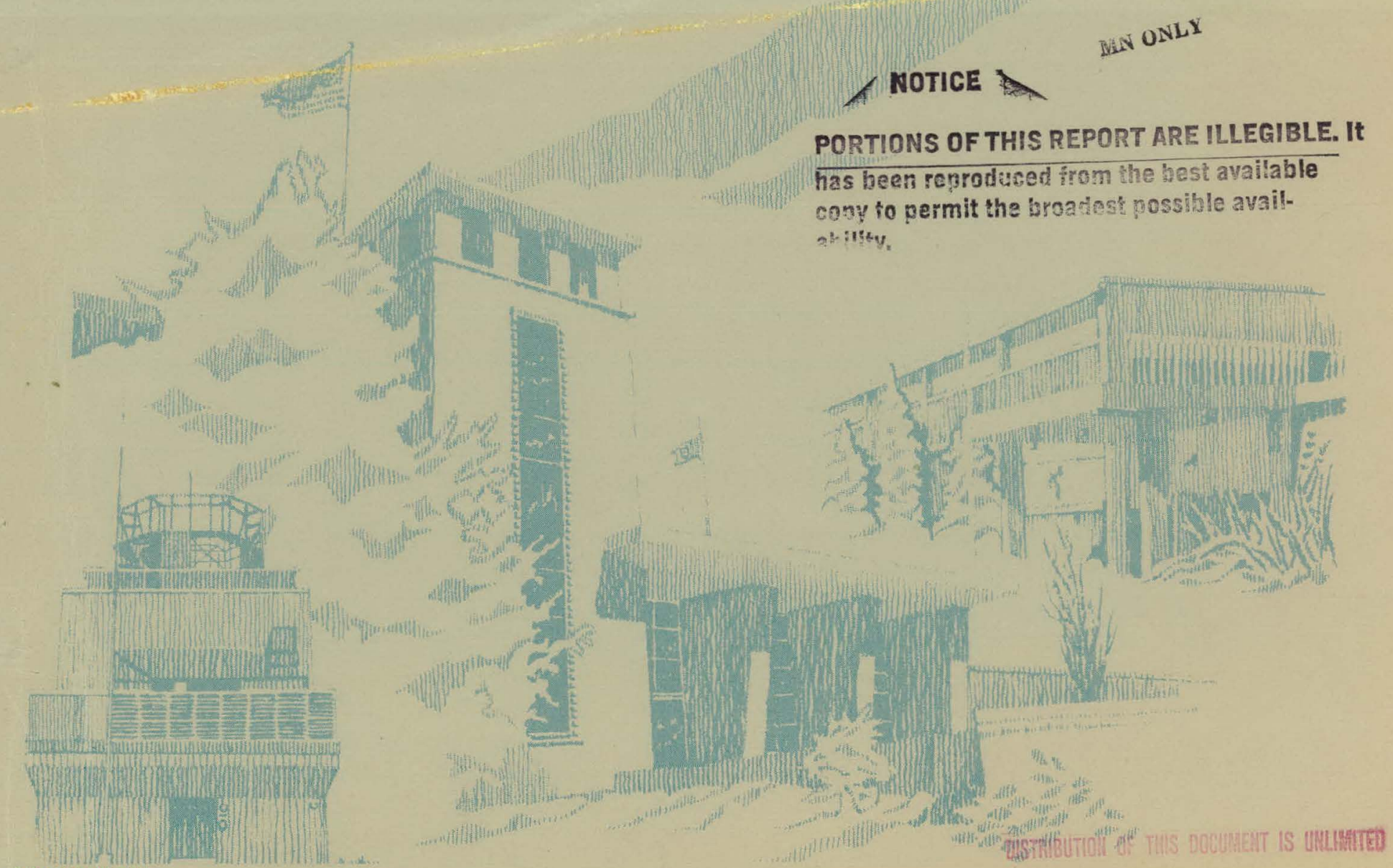




\section{DISCLAIMER}

This report was prepared as an account of work sponsored by an agency of the United States Government. Neither the United States Government nor any agency Thereof, nor any of their employees, makes any warranty, express or implied, or assumes any legal liability or responsibility for the accuracy, completeness, or usefulness of any information, apparatus, product, or process disclosed, or represents that its use would not infringe privately owned rights. Reference herein to any specific commercial product, process, or service by trade name, trademark, manufacturer, or otherwise does not necessarily constitute or imply its endorsement, recommendation, or favoring by the United States Government or any agency thereof. The views and opinions of authors expressed herein do not necessarily state or reflect those of the United States Government or any agency thereof. 


\section{DISCLAIMER}

Portions of this document may be illegible in electronic image products. Images are produced from the best available original document. 
Issued by Sandia National Laboratories, operated for the United States Department of Energy by Sandia Corporation.

NOTICE: This report was prepared as an account of work sponsored by an agency of the United States Government. Neither the United States Government nor any agency thereof, nor any of their employees, nor any of their contractors, subcontractors, or their employees, makes any warranty, express or implied, or assumes any legal liability or responsibility for the accuracy completeness, or usefulness of any information, apparatus, product, or procompleteness, or usefulness of any information, apparatus, product, or process disclosed, or represents that its use would not infringe privately owned
rights. Reference herein to any specific commercial product, process, of service by trade name, trademark, manufacturer, or otherwise, does not necessarily constitute or imply its endorsement, recommendation, or favorin by the United States Government, any agency thereof or any of their contractors or subcontractors 政 not necessarily state or reflect those of the United States Government, any agency thereof or any of their contractors or subcontractors.

\author{
Printed in the United States of Americe \\ Available from \\ National Technical Information Service \\ U.S. Department of Commerce \\ 5285 Port Royal Road \\ Springfield, VA 22161 \\ NTIS price codes \\ Printed copy:
}

Microfiche copy: A01 


\section{PAGES $\mathrm{i}$ to $\mathrm{ii}$ WERE INTENTIONALLY LEFT BLANK}


Unlimited Release

Printed January 1982

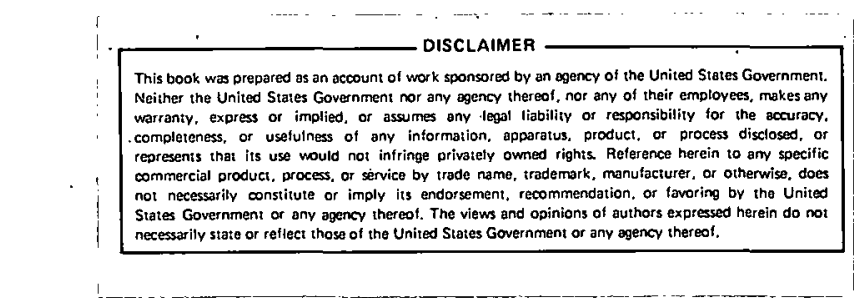

SANDIA PHOTOVOLTAIC SYSTEMS DEFINITION AND APPLICATION EXPERIMENT PROJECTS

Third Project Integration Meeting

February 9, 10, 11, 1982

Albuquerque, NM

Photovoltaic Systems Development Division 4723

Sandia National Laboratories

Albuquerque, NM 87185
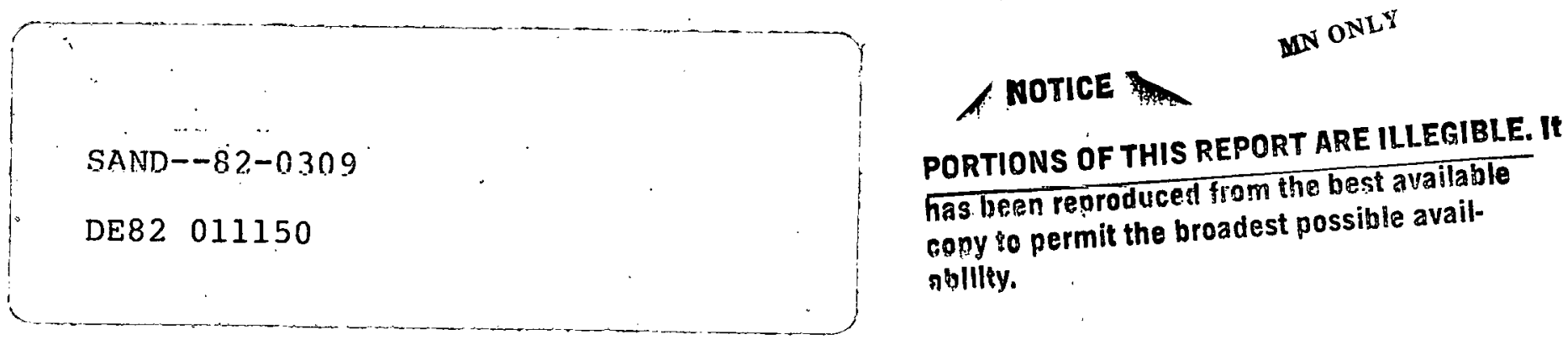

\section{ABSTRACT}

This report contains abstracts of presentations given at a project review meeting held at Albuquerque, NM. The proceedings cover the past accomplishmerts and current activities of the Photovoltaic Systems Research, Balancc-of-System Technolngy Development and System Application Experiments Projects at Sandia National Laboratories. The status of intermediate system application experiments and residential system analysis is emphasized. Some discussion of the future of the Photovoltaic Program in general, and the Sandia projects in particular is also presented. 
Meeting objectives........................ 1

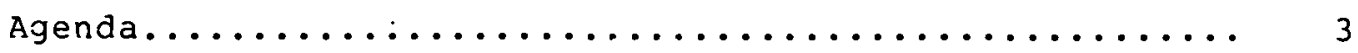

Line organization Chart.................... 7

Project Personnel List...................... 8

Present and Future Federal Role In Photovoltaics....... l'0

Sandia Photovoltaic Activities.................... 11

Systems and Applications Overview................. 12

MIT Intermediate-Sized Field Experiments........... 13

ORNL Photovoltaic Projects.................... 18

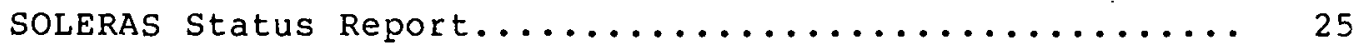

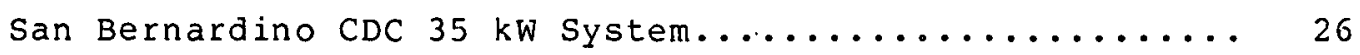

NMSEI/El Paso Electric $20 \mathrm{~kW}$ System............... 27

Lea County Electric $100 \mathrm{kw}$ system................ 36

Beverly High School $100 \mathrm{~kW}$ system............... 43

Oklahoma City $135 \mathrm{kw}$ system....................... 50

Ilawaii Hospital $35 \mathrm{kw}$ system.................. 63

Commercial Application of Photovoltaic Concentrator

systeilis.............................. 74

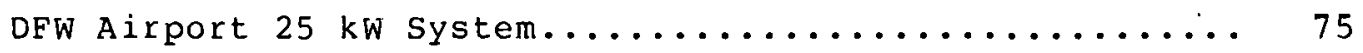

Phoenix Airport $225 \mathrm{kw}$ system................. 86

Systems Activity Overview.................... 91

Solar PV kesidential Project at MIT/LL............ 95

Sandia Residential project................... 96

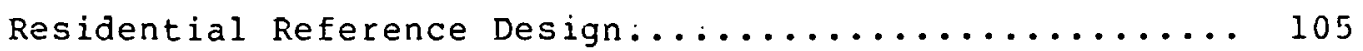

Photovoltaic Retrofit Analysis................. ll6

Residential Load Characterization............... 123 
Investigation of Load Management Strategies For

Residential Photovoltaic systems................. 128

Photovoltaic Energy scenario study............... 132

Activity overview......................... 133

Array Field Optimization................... 138

Array Field Optimization................... 147

Concentrator Array Field Optimization............. 157

Integrated structure Design.................. 171

Automated Installation Methods................. 181

Flat-Plate Array Characterization................ 194

PV Modelling For Utility Simulations............. 202

Case STudies of Distribution Line/PV.............. 210

Power-Conditioning Subsystem Evaluation Test

Requirements............................. 221

Power Conditioning Subsystems Engineering Evaluation

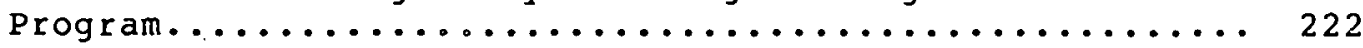

Advanced Design for Intermediate-size Power

Conditioning subsystem...................... 228

Investigation of A Family of Power Conditioners Integrated

In To The Utility Grid..................... 236

CONTRACT SMATUS SUMMARIES

Design Modification And Production Engineering For The

Abacus Sunverter

Abacus Controls, Inc........................ 245

Design And Construction of A $75 \mathrm{~kW}$ Photovoltaic Array Simulator

Abacus Controls Inc......................... 247

Design And Construction of A Concentrating photovoltaic Total Energy System In Hawai

Acurex Corporation.......................... 249

Photovoltaic off-Farm Agricultural Applications

Advanced Technology, Inc.................... 250 
Phoenix Sky Harbor Airport Photovoltaic Concentrator Project

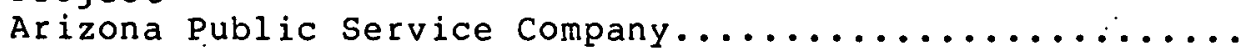

Study of Photovoltaic Intermediate Sector

Retrofits

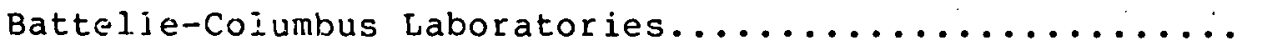

Photomitaic Flat-Panel Array Field Optimization

And Mociulazity sturiy

Battolle-Coiun! :

Photovoltaic : juicentrator Array Field

Optinization And Modularity Study

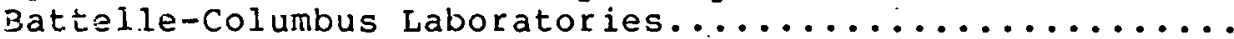

Development of A Photovoltaic Systems Reliability

Analysis Methodology And Reliability-Econonics

Assessment

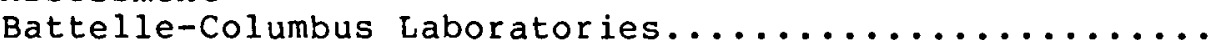

Detailed Residential Electric Load Determination

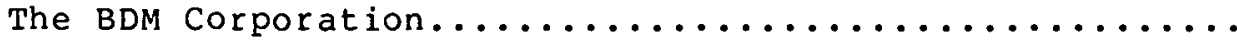

Analysis of concentrating PV/T Systems For The Commercial/Industrial SEctor

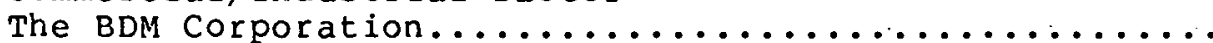

Integrated Structure Designs For Photovoltaic Arrays

Bechtel Group, Inc.........................

The Data Reduction Center For Photovoltaic

Applications Experiments

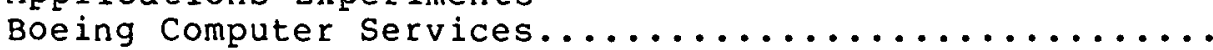

Investigation $O F$ Load Manageinent Strategies For

Residential Photovoltaic systems

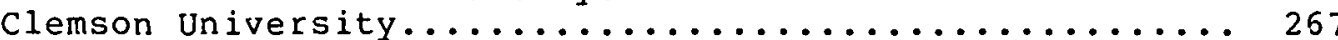

Investiyation of A Family of fower conattioners' Integrated Into The Utility Grid

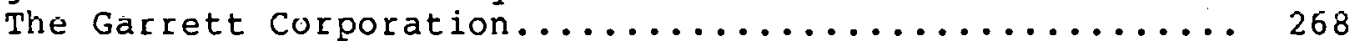

Initial Detailed Designs For Intermediate PV Systems

General Electric Company........................ 269

Analysis of Small Commercial PV Applications

General Electric Company........................ 270

Detailed Residential Photovoltaic preferred Designc

General Electric Company....................... 271 
Photovoltaic Array Field Optimization And Modularity Study

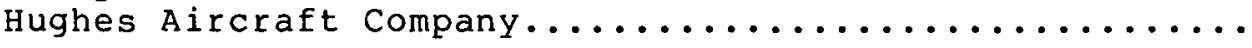

Power-Conditioning Subsystem Evaluation Test Requirements Massachusetts Institute of Technology..............

Electrical Overstress Damage In Silicon Solar Cells

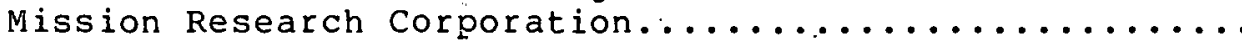

DOE Photovoltaic Grant Projects

Mississippi County Community College............. 276

Analysis of Low Energy Density Photovoltaic

Applications

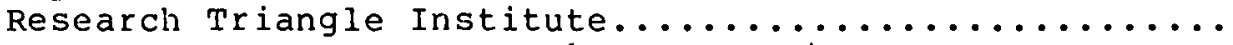

135 k.W Photovoltaic system For The oklahoma Center For Science \& Arts

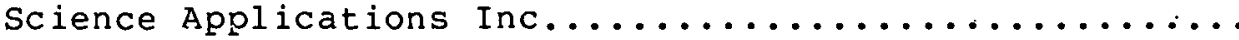

A 100 Kilowatt Solar Photovoltaic Flat Panel power

System For The Beverly High School, Beverly, MA

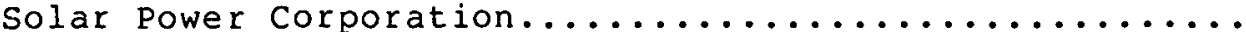

Photovoltaic Power Processing Unit For Line Interface Using $20 \mathrm{kHz}$ PWM Techniques

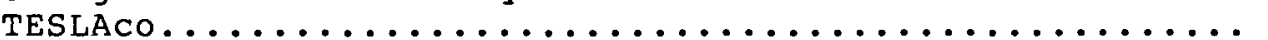

Photovoltaic Residential Retrofits

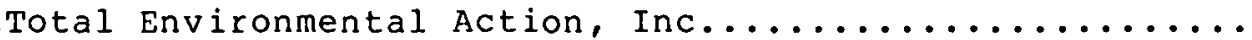

Investigation of A Family of Power Conditioners

Integrated Into The Utility Grid

United Technologies Corporation..................

Photovoltaic Energy Scenario Study

General Electric Company..................... 286 
THIRD PROJECT INTEGRATION MEETING

OF THE

SANDIA PHOTOVOLTAIC SYSTEMS DEFINITION AND

APPLICATION EXPERIMENT PROJECTS

Meeting Objectives

This is the Third Project Integration Meeting for the Sandia Photovoltaic Systems Definition and Application Experiment Projects. The objectives of this meeting are:

To review the current understanding of photovoltaics system design and development, assisting in the transfer of this technology to industry.

To exchange information on on-going work and system-related activities.

To provide a means of coordinating project and program activities.

This meeting will emphasize the experience gained in the intermediate application experiments, and the current state of residential systems research activities. Presentations will also cover array field engineering, power conditioning interface analysis, and intermediate-size power conditioning design research. 


\section{THIRD SYSTEM AND APPLICATIONS}

\section{PROJECT INTEGRATION MEETING.}

FEBRUARY $9,10,11,1982$

\section{TUESDAY FEBRUARY 9}

SESSION I

Chairman: E. L. Burgess

$7: 45-8: 45$

Registration

$8: 45-8: 55$

Welcome

G. J. Jones, Sandia National Laboratories

$8: 55-9: 20$

National projram Overview

L. Sarrett, DOE Headquarters

$9: 20-9: 4: 0$

Sandia Fhotovoltaic Activities

D. Schueler, Sandia National Laboratories

9:40-10:00 Systens \& Applications Overview

R. V. Powell, Jet Propulsion Laboratory

$10: 00-10: 30$

BREAK

SESSION IB

Chairman: E. L. Burgess

10:30-10:50 MIT Intermediate-sized Field Experiments

John Solman; MIT

10:50-11:10 OKNL Photovoltaic Projects

Steve Kaplan, Oak Ridge National Laboratory

$11: 10-11: 30 \quad$ SOLERAS status Report.

Fahad Huraib, Saudia Arabian Government

1.1:30-11:50 San Bernardino CDC $35 \mathrm{~kW}$ System

Marvin Stary, San Bernardino 
SESSION II

Chairman:

C. Rogers

$1: 30-1: 50$

NMSEI/El Paso Electric $20 \mathrm{~kW}$ system

Vern Risser, NMSEI

$1: 50-2: 10$

Lea County Electric $100 \mathrm{kw}$ system

Pete Felfe, Lea County Electric Co-op

$2: 10-2: 30$

Beverly High School $100 \mathrm{kw}$ System

Lick Addiss, Solar Power

$2: 30-2: 50$

Oklahoma City $135 \mathrm{~kW}$ System

Yudi Gupta, Science Applications Inc.

SESGION IIE

Chairman: K. Biringer

$3: 15-3: 35$

Hawail Hospital $35 \mathrm{~kW}$ System

Dariush Rafinejad, Acurex

$3: 35-3: 55$

BDM Office Building $50 \mathrm{~kW}$ system

Wayne Kaufman, BDM

$3: 55-4: 15$

DFW Airport $25 \mathrm{~kW}$ System

Mark O'Neill, E-Systems

$4: 15-4: 35$

Phoenix Airport $225 \mathrm{~kW}$ System

Joe McGuirk, Arizona Public Service Co.

\section{WEDNESDAY FEBRUARY 10}

\section{SESSION III}

Chairman: G. J. Jones

Fesidential system Definition \& Development

$8: 30-8: 55$

Systems Activity Overview

J. L. Jackson, Sandia National Laboratories

$8: 55-9: 15$

Solar PV Residential project at MIT/LL

E. Kern, MIT/LL

$9: 15-9: 35$

Sandia Residential Project

K. Biringer, Sancia National Laboratories

$9: 35-10: 00$

Residential Reference Design

E. Mehalick, General Electric 
$10: 00-10: 30$

$10: 30-10: 55$

$10: 55-11: 20$

$11: 20-11: 45$

$11: 45-12: 00$

\section{BREAK}

Photovoltaic Retrofit Analysis

D. Mahone, TEA

Residential Load Characterization

G. Collaros, BDM

J. Lathrop, Clemson University

Energy Scenario Effects

G. Bonk, General Electric

Summary \& Conclusions

G. Jones, Sandia National Laboratories

SESSION IV

Chairman: H. Post

Array Subsystem Development

$1: 30-1: 45 \quad$ Activity Overview

H. N. Post, Sandia National Laboratories

$1: 45-2: 20$ Array Field optimization

D. C. Carmichael, Battelle-Columbus Labs

2:20-2:55 Array Field Optinization

J. A. Castle, Hughes Aircraft Company

\section{BREAK}

$3: 25-3: 45$

$3: 45-4: 05$

$4: 05-4: 30$
Concentrator Array Field optinization

D. C. Carmichael, Eattelle-Columbus Labs

Integrated structure Design

H. A. Franklin, Bechtel. Group

Automated Installation Methoàs

J. R. Oster, Jr. Burt Hill Kosar Rittelmann Assoc. 


\section{THURSDAY FEBRUARY 11}

\section{SESSION $V$}

Chairman: T. key and $C$. Cox

Power Conditioning and control

$8: 30-8: 40$

Session Introduction

T. Key, Sandia National Laboratories

$8: 40-9: 10$

Flat-Plate Array Characterization

C. Gonzales, JPL/LSA

$9: 10-9: 40$

P.V. Modelling For Utility Simulations

o. Wasynczuk, Purdue University

$9: 40-10: 10$

Case Studies of Distribution Line/PV

Interactions

J. Solman, MIT/LL

J. Fitzer, University of Texas, Arlington

$10: 30-10: 50$

$10: 50-11: 10$

$11: 10-11: 50$

$11: 50-12: 00$

$1: 00-2: 00$
PCS Evaluation Test Requirements

C. CoX, MIT/LL

Engineering Evaluation Status/Plans

w. Bower, Sandia National Laboratories

Advanced Design for Intermediate-size power Conditioning Subsystem

J. King, United Technologies Corporation

T. Prouty, Garrett Air Research

Closing Comments and Adjournment

G. Jones, Sandia National Laboratories

Tour of BDM System

(Optional) 
ThP P PACKLET

ORGANIZATIONAL STRUCTURE OF THE SANDIA SOLAR PROGRAMS

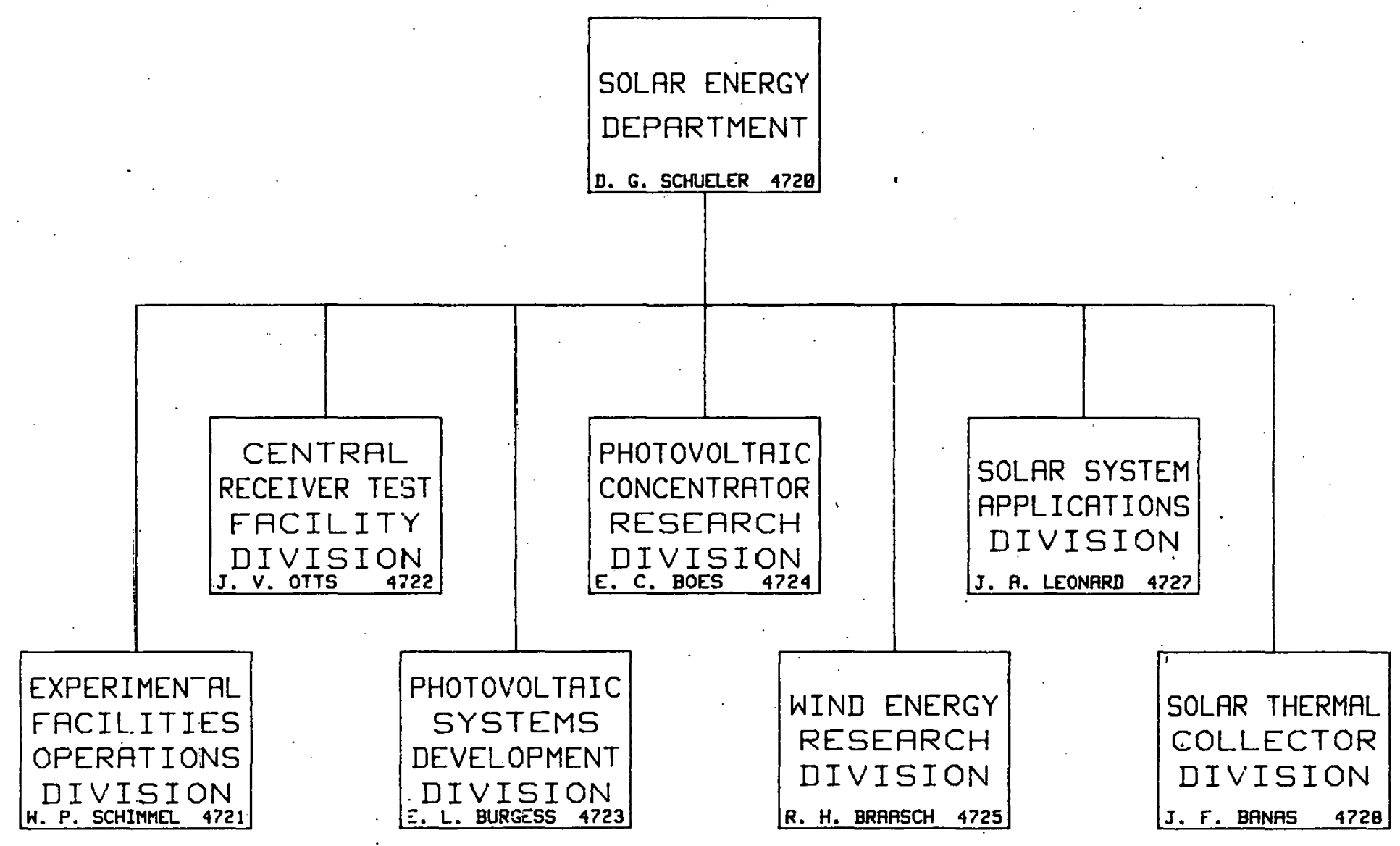


SANDIA PHOTOVOLTAIC PROJECTS

$$
1-5-82
$$

\begin{tabular}{|c|c|c|c|}
\hline - & & $\begin{array}{l}\text { Oryanization } \\
\text { Number }\end{array}$ & $\begin{array}{l}\text { Phone } \\
8 \underline{844}\end{array}$ \\
\hline rojects Manager: & SCHUELER， DON & 4720 & 4041 \\
\hline
\end{tabular}

Systems Definition \& Development Project

$\begin{array}{llrr}\text { Project Leader: } & \text { JONES, Gary } & 4723 & 2433 \\ \text { Systems Analysis: } & \text { CASKEY, Dave } & 2525 & 7704 \\ & \begin{array}{l}\text { JACKSCN, Jack } \\ \text { Array Subsystems: }\end{array} & 4723 & 7825 \\ \text { Power Conditioning: Hal } & 4723 & 2154 \\ & \text { BOWER, Ward } & -2157 & 5206 \\ & \begin{array}{l}\text { CHU, Dahwey } \\ \text { COATS, Mo }\end{array} & 4723 & 5-2457 \\ & \text { KEY, TOm } & 4165 & 5206 \\ & & 4723 & 3043\end{array}$

System_\& Component Test Project

\begin{tabular}{|c|c|c|c|}
\hline ject Leader: & SCHIMMEL, walt & 4721 & 9904 \\
\hline & $\begin{array}{l}\text { CANNON, Jack } \\
\text { GERWIN, HOWard } \\
\text { LUNDGREN, Ron } \\
\text { PETTERSON, Ben } \\
\text { PRITCHARD, Dan } \\
\text { TORKELSON, Leroy } \\
\text { WORKHOVEN, Bob }\end{array}$ & $\begin{array}{l}4721 \\
4721 \\
4721 \\
4721 \\
4721 \\
4721 \\
4721\end{array}$ & $\begin{array}{r}\sigma-0621 \\
0112 \\
6-0782 \\
3733 \\
0026 \\
6-0027 \\
5427\end{array}$ \\
\hline
\end{tabular}

Concentrator Technology Project

Project Leader:

BOES, Eldon

4724

5634

Cell Developinent:

(Silicon)

WEAVER, Harry

2146

8979

GAKNEK, Mike

2146

2351

NASBY, Robert

2146

RODRIGUEZ, Jose 2146

6137

ROSE, B. H.

2146

6137

4300

(Ađ̃vanced)

CHAFFIN, Roge $r$

5133

2609

DAWSON, Fialph

HAMMONS, B. E.

5154

WICZER, Jami?

5132

5133 
SANDIA PHOTOVOLTAIC PROJECTS (Continued)

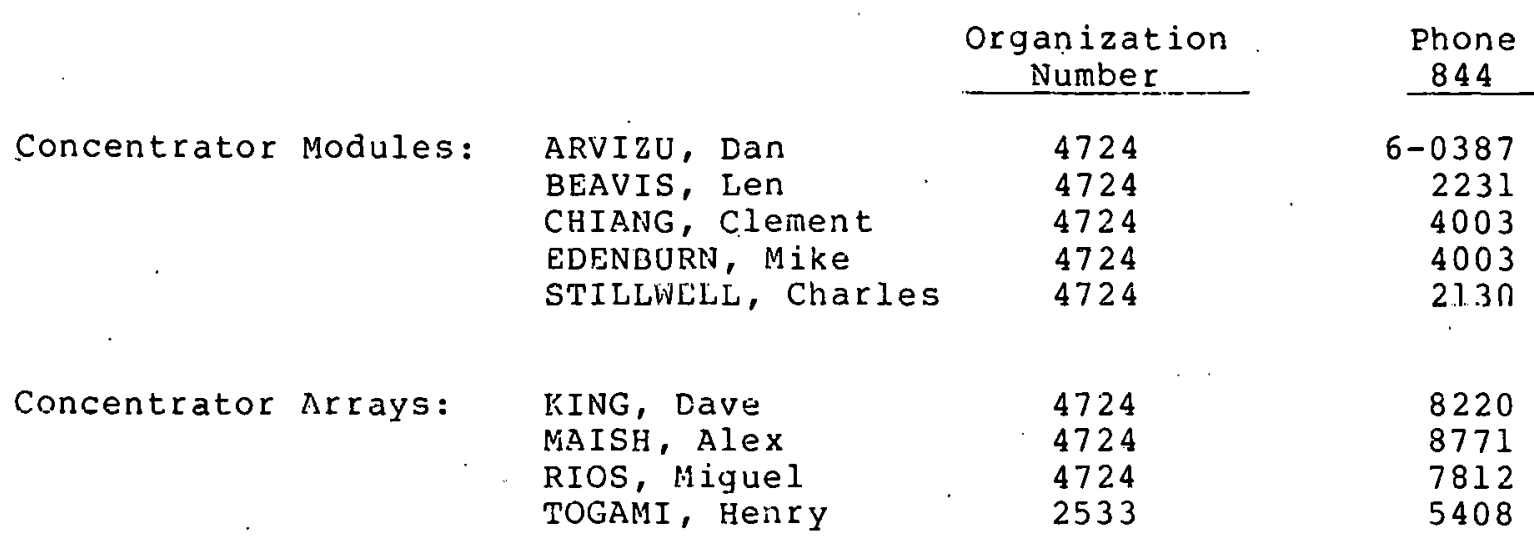

\section{System Applications Project}

\begin{tabular}{|c|c|c|c|}
\hline Project Manager: & BURGESS, Ed & 4726 & 2178 \\
\hline \multicolumn{4}{|l|}{ Data \& Information } \\
\hline & $\begin{array}{l}\text { EVANS, Tom } \\
\text { NAKAOKI, Cal } \\
\text { PRUETT, Hal }\end{array}$ & $\begin{array}{l}2532 \\
2532 \\
2532\end{array}$ & $\begin{array}{l}8867 \\
6257 \\
2807\end{array}$ \\
\hline \multicolumn{4}{|c|}{ Experimental projects: } \\
\hline : & $\begin{array}{l}\text { BAXTER, Hal } \\
\text { BIRINGER, Kent } \\
\text { HARRIGON, Tom } \\
\text { ROGERS, Cal }\end{array}$ & $\begin{array}{l}4726 \\
4726 \\
4726 \\
4726\end{array}$ & $\begin{array}{r}6-0781 \\
2387 \\
6394 \\
2387\end{array}$ \\
\hline
\end{tabular}

Other

DOE/ALO Solar Projects

Division

WALKER, Ethan

ALO/SPD

$6-5209$ 
PRESENT \& FUTURE FEDERAL ROLE. IN PHOTOVOLTAICS

A. Lee Barrett

U.S. Departinent of Energy

Photovoltaics, in scaled-down budget, is entering an era in which Federal support shall be focused on longer-term, high risk, high-payorf R\&D which private industry can not reasonably be expected to undertake. DOE's role shall be to work with industry and universities supporting critical research and development of potentially low-cost, reliable PV materials, collectors and components to the point of technical feasibility.

Industry's role in the continuing evolution of photovoltaics will also change. In the next few years, activities such as technology and engineering development, demonstrations, commercial production and operation, in which the Federal Government played a major role in the past, shall be shifted in responsibility solely to that of private industry.

The Federal Government, nevertheless, shall continue in its role as the focal point for basic and apolied research. The FY82 budget appropriations for the photovoltaic program has been scaled-down to reflect this new philosophy. Changes in organizational structure at DOE's Photovoltaic Division have already been effected to implement its new role. In this new era, launched in FY82, private industry will be expected to assume full responsibility for system development, marketing and deployment. 
FEDERAL PHOTOVOLTAICS PROGRAM OVERVIEW

\section{PHOTOVOLTAICS PROGRAM ORGANIZATION}

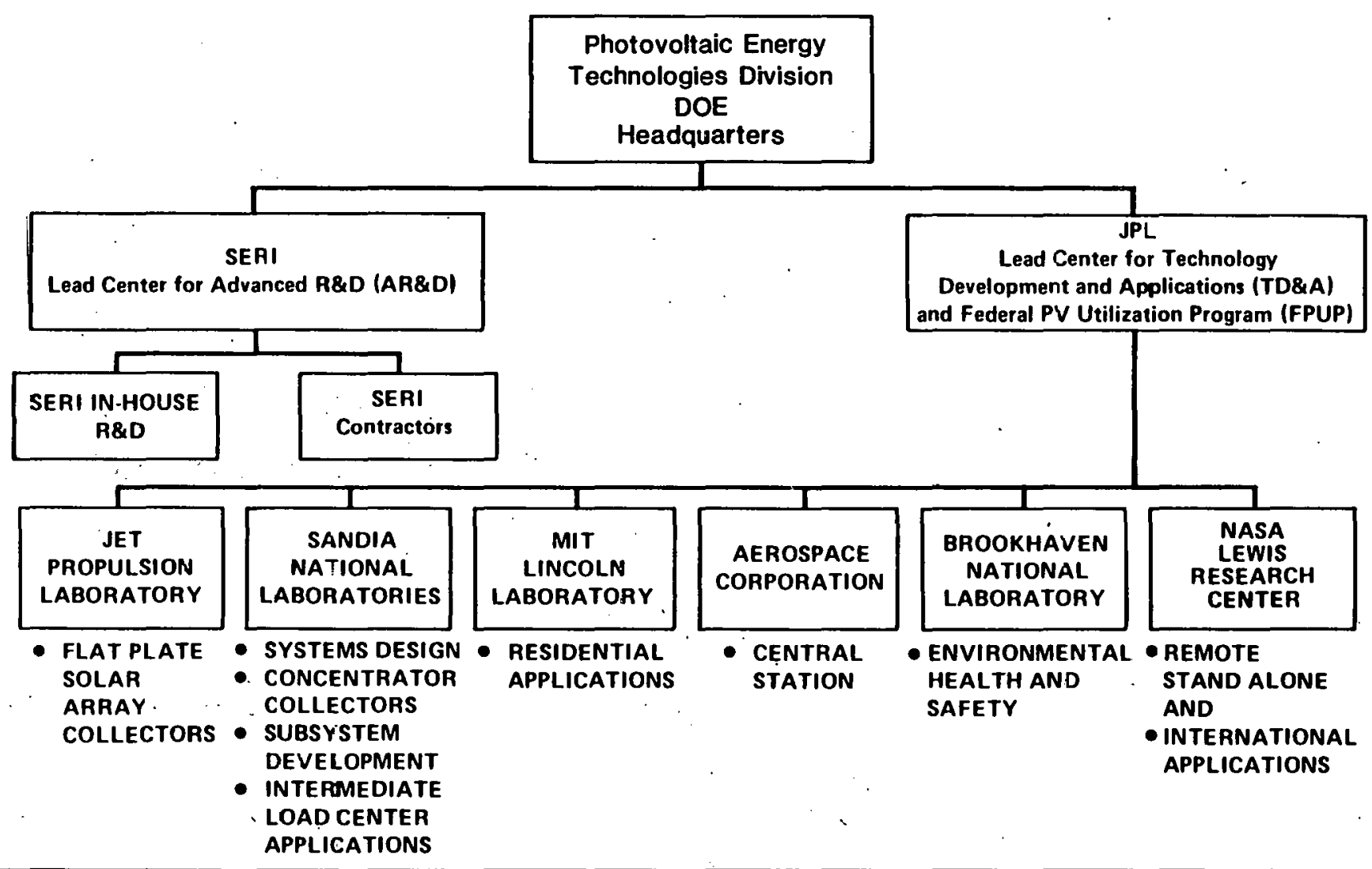

INDUSTRY AND UNIVERSITY CONTRACTORS 


\section{NATIONAL PHOTOVOLTAICS PROGRAM PROGRAM OBJECTIVES}

The objectives of the National Photovoltaics Program are:

(1) To focus support on longer-term, high-risk, high-payoff R\&D which private industry cannot reasonably be expected to undertake to advance scientific understanding and establish a technology base.

(2) To work with industry and universities supporting critical research and development of potentially low-cost, reliable PV materials, collectors and components to the point of technical feasibility. 


\section{NATIONAL PHOTOVOLTAICS PROGRAM PROGRAM STRUCTURE}

\begin{tabular}{|c|c|c|c|c|c|c|}
\hline $\begin{array}{l}\text { Stage of } \\
\text { Development } \\
\text { PV } \\
\text { Program } \\
\text { Category }\end{array}$ & $\begin{array}{l}\text { Basic } \\
\text { and } \\
\text { Applied } \\
\text { Research }\end{array}$ & $\begin{array}{l}\text { Exploratory } \\
\text { Development }\end{array}$ & $\begin{array}{l}\text { Technology } \\
\text { Development }\end{array}$ & $\begin{array}{l}\text { Engineering } \\
\text { Development }\end{array}$ & Demonstration & $\begin{array}{l}\text { Commercial } \\
\text { Production } \\
\text { and } \\
\text { Operation }\end{array}$ \\
\hline $\begin{array}{l}\text { Material, } \\
\text { Cell, } \\
\text { Device R\&D }\end{array}$ & & LTF & & & & \\
\hline $\begin{array}{l}\text { High-Risk } \\
\text { Collector } \\
\text { R\&D }\end{array}$ & & $\begin{array}{r}v \$ 0 \\
\$ 0 .\end{array}$ & $\begin{array}{l}70 / w_{p} T^{T}= \\
40 / w_{p} \nabla\end{array}$ & & sTh. & \\
\hline $\begin{array}{l}\text { High-Risk } \\
\text { Sub.System } \\
\text { R\&D }\end{array}$ & & & $\stackrel{\text { TF }}{\nabla}$ & ande & & \\
\hline $\begin{array}{l}\text { High-Risk } \\
\text { System } \\
\text { R\&D }\end{array}$ & & $\begin{array}{l}\text { mplete } \\
\text { igoing } \\
\text { tivities }\end{array}$ & & & & \\
\hline
\end{tabular}




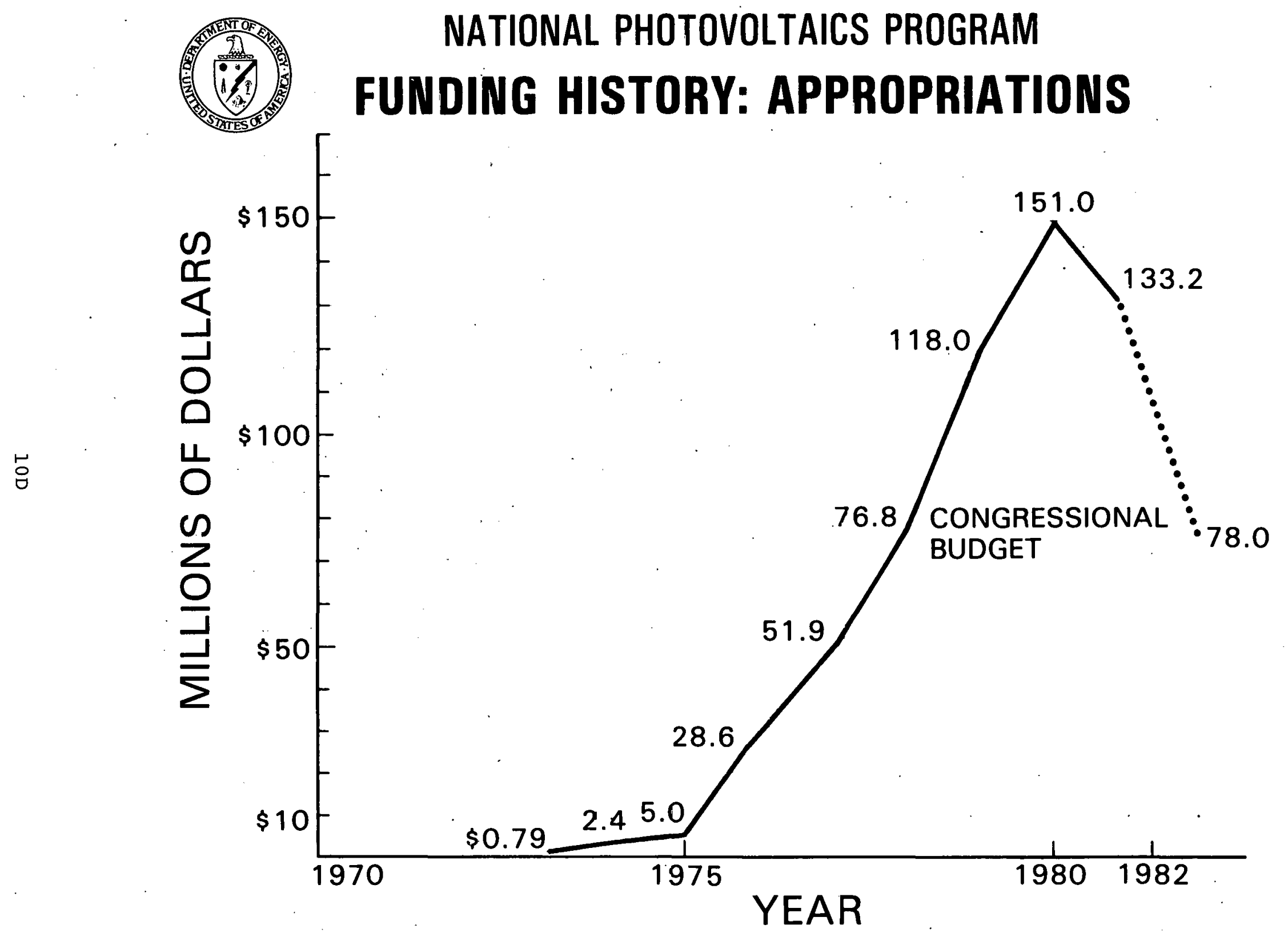




\section{NATIONAL PHOTOVOLTAICS PROGRAM SUMMARY OF THE FEDERAL ROLE}

(1) Market development and industry development activities and commercial availability goals are deleted

(2) Research and Development will emphasize highrisk PV technology and components that will aid industry in development of cost-competitive photovoltaics

(3) Emphasis placed on broadening the technology base not on system development or deployment

(4) Lay ground-work for further private industry development and commercial production 


\section{NATIONAL PHOTOVOLTAICS PROGRAM CHALLENGE TO INDUSTRY}

(1) Evolution of Federal Program challenges private industry to shoulder the burden of photovoltaic system development, marketing and deployment

(2) Industry must continue successful expansion of existing photovoltaic markets

(3) Industry is challenged to build and monitor system experiments and continue to pursue the industrial development of DOE R\&D activities to the point where photovoltaics can compete in U.S. utility markets 
D. G. Schueler

Sandia National Laboratories

Albuquerque, NM 87185

Sandia National Laboratories is responsible for the planning, implementation, and management of a number of activities which are part of the DOE National Photovoltaic Program. These activities include systems and subsystems research, system application experiments, concentrating collector research, and test facility operation. A new responsibility beginning in the current fiscal year is management of the photovoltaic residential project. The organization of these activities into projects and associated tasks, along with the responsible sandia manager, is shown in the accompanying organization chart.

During the current fiscal year, a number of changes in the scope and objectives of the Sandia photovoltaic activities will be made. These changes reflect the new emphasis of the DOE Photovoltaic Program on long-range, high-risk research and development and de-emphasis of commercialization and market development. System and subsystem (balance-of-system) research will be reduced to a minimum critical level consistent with bringing on-going activities to logical conclusion and documenting the significant results of the work. Photovoltaic system application experiments will continue to be operated during the fiscai year with their disposition determined on a case-by-case basis. Photovoltaic concentrator research will continue at a reduced scope with emphasis on improvement in module conversion efficiency. 


\section{PROJECT STRUCTURE OF THE SANDIA PHOTOVOLTAIC ACTIVITIES}

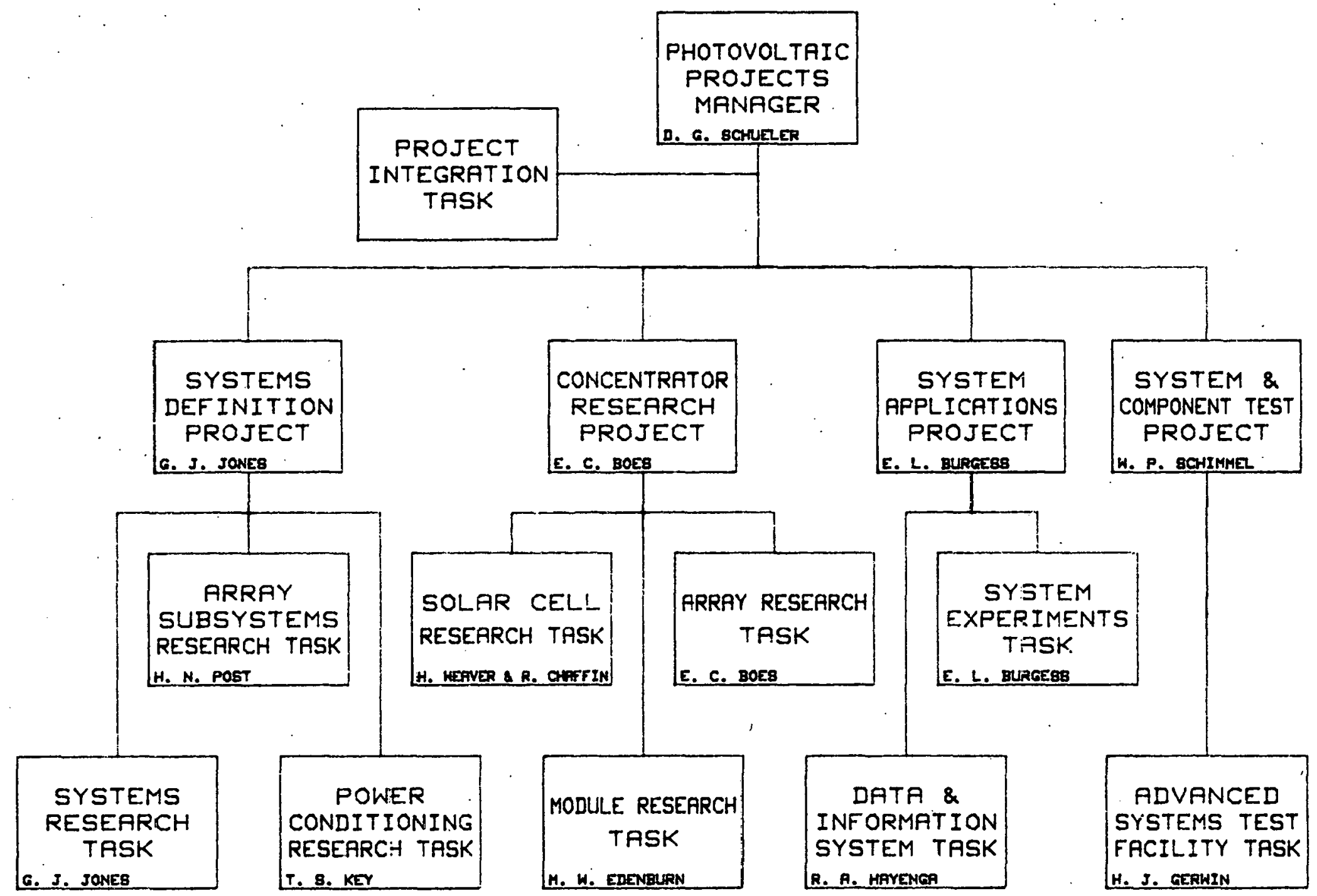


Third Systems and Applications

Project Integration Meeting

February $9-11,1982$

Systems and Applications Overview

R.V. Powe 11

Jet Propulsion Laboratory

The disciplines of Systems Research, Subsystems Development, and Systems Tests have recently been consolidated into a single subprogram called "Systems Research and Technology". It is this consolidated subprogram which we will overview here. Field center assignments are commented on. Comment is also made on the current DOE/PV Headquarters Organization as well as the JPL/LC Organization which reflect that consolidation.

The trend as we 11 as the scope of the Systems Research and Technology Subprogram is indicated by a review of funding history and a brief summary of achievement highlights in each of the discipline areas. Notable progress in each of the discipline areas is evident. What is also conspicuous in these highlights is the existence of a large heritage of PV systems level test experience complimented by a comparable body of system design methodology currently being validated by that experience.

A major thrust of the current program is to achieve a transition from the strong subsystem development, systems research and systems level test orientation to a high risk research orientation. That transition will be accompanied by technology transfer effort that will assure continuing access by the PV industry and PV users to the substantial heritage which results from the DOE/PV.Program. Attendant to the technology transfer is the planned completion of on-going tasks which contribute significantly to the technology base to be transferred.

This transition is also expected to result in a core systems research activity supported at a modest level which will compliment the high risk/long term photovoltaic research tasks. This core systems activity will provide systems analysis to support research target selection and resource relocation decisions as well as some component test and evaluation to valid the research results.

As a closing remark, we should observe that despite a somewhat earlier phase out of the PV System Research and Test Activities than planned, we expect to to achieve a major, documemented contribution to the PV technology base. 


\title{
SYSTEMS AND APPLICATIONS OVERVIEW
}

\author{
by \\ R.V. Powell \\ Jet Propulsion Laboratory
}

February 9, 10, 11, 1982

Albuquerque, New Mexico 


\section{SYSTEMS AND APPLICATIONS OVERVIEW}

DOE PHOTOVOLTAICS PROGRAM

DOE'CONSERVATION AND SOLAR ENERGY

ORG ANIZATION WITH EMPHASIS ON

SOLAR PV ENERGY SYSTEMS

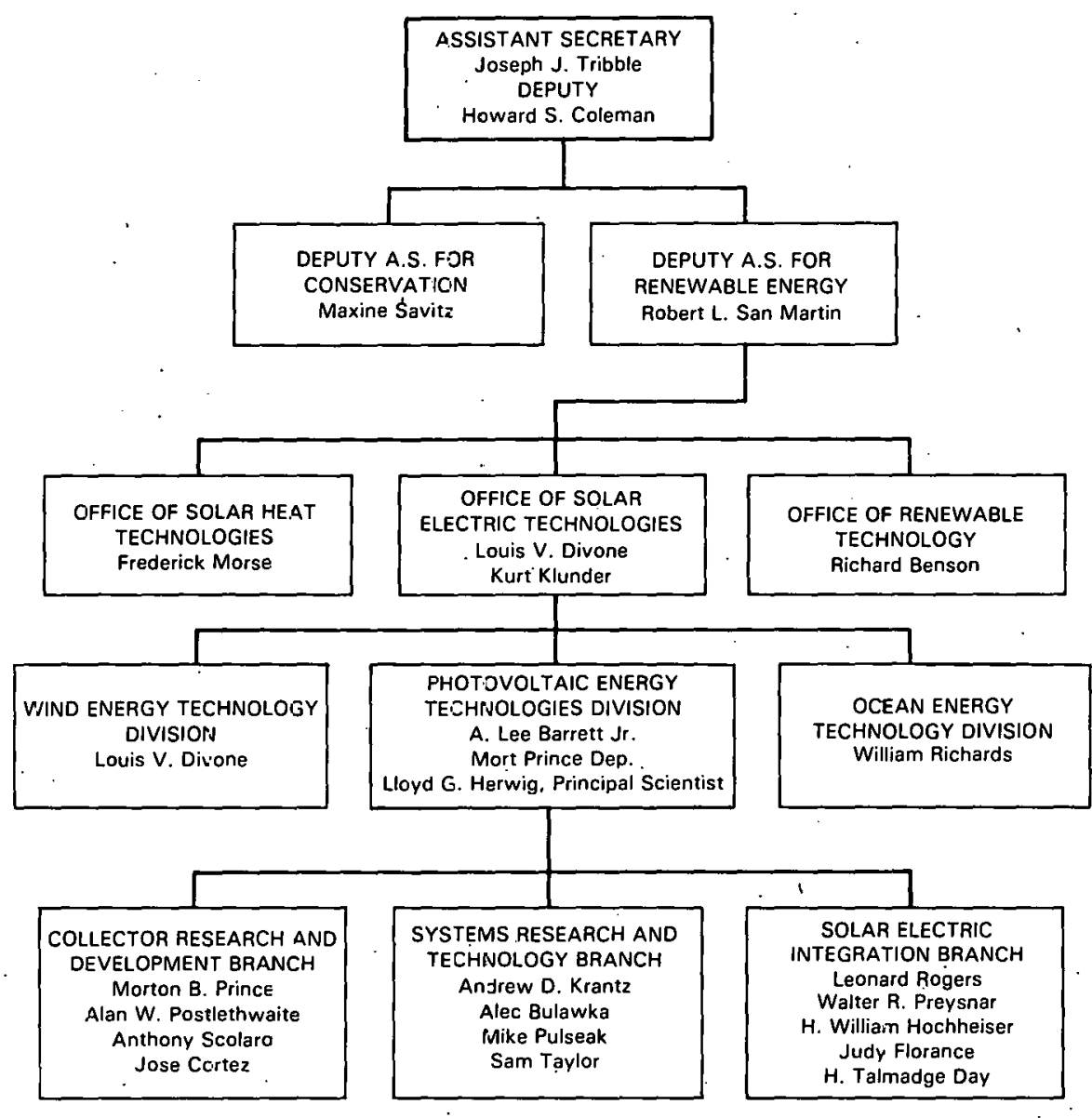




\section{SYSTEMS AND APPLICATIONS OVERVIEW}

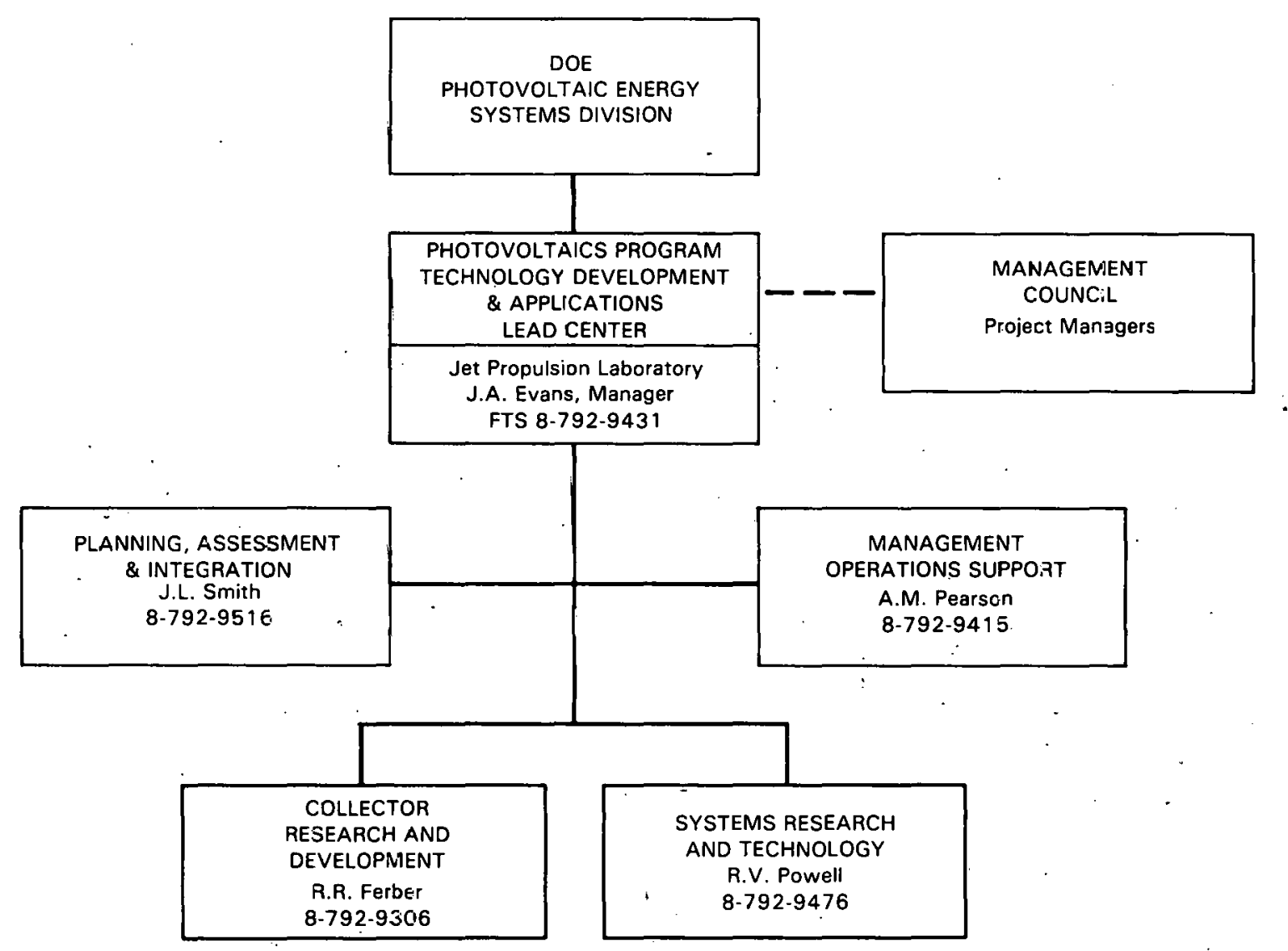




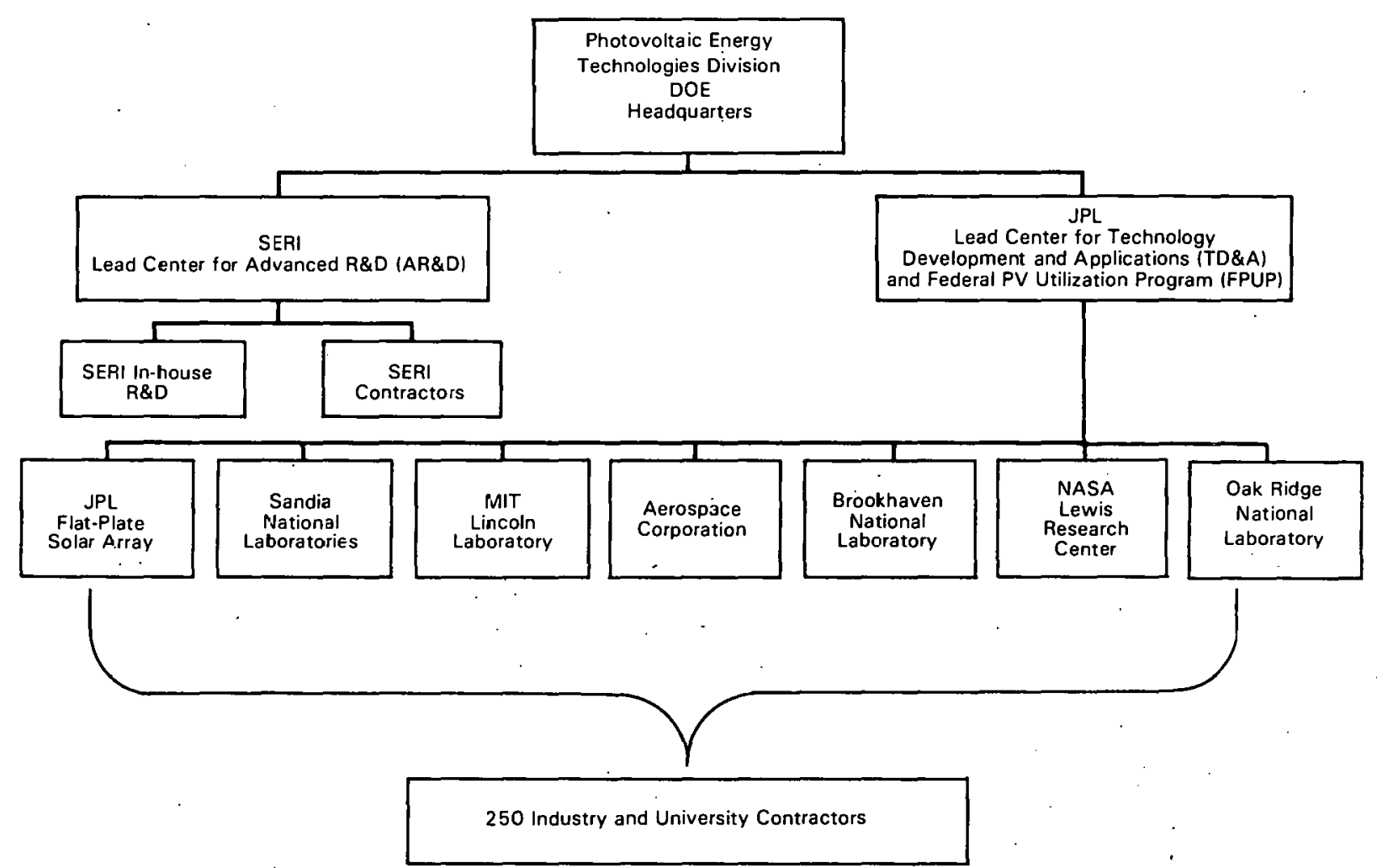


SYSTEMS AND APPLICATIONS OVERVIEW

\section{FUNDING HISTORY}

$\begin{array}{lccccc} & \text { FY 79 } & \text { FY } 80 & \text { FY } 81 & \text { FY } 82 & \text { FY } 83 \\ \text { SYSTEMS ENGINEERING } & 6.5 & 14.5 & 15.0 & 2.9 & \\ \text { SUBSYSTEMS DEVELOPMENT } & 0 & 13.0 & 13.0 & 5.4 & \text { TBD } \\ \text { TESTS AND APPLICATIONS } & 23.7 & 24.5 & 15.0 & 21.7 & \end{array}$




\section{SYSTEMS AND APPLICATIONS OVERVIEW HIGHLIGHTS OF SYSTEMS RESEARCH}

- RESs operational; 13 prototype under test

- Residential "preferred" designs complete

- Subsystem optimization and trade-off study complete (Bechtel)

- PRDA 35/38 designs documented

- Utility interface issues characterized; analysis in progress

- Design "handbooks" published for remote stand-alone and utility-connected systems 


\section{HIGHLIGHTS OF SYSTEMS RESEARCH (cont'd)}

- Interim performance criteria document published

- Residential retrofit study complete

- Intermediate reference designs complete (GE)

- Central station reference designs in progress (Martin Marietta)

- Photovoltaic cost elements model complete (TB\&A) 


\section{HIGHLIGHTS OF SUBSYSSTEM DEVELLPMENT}

- Array optimization and modularity studies complete (Battelle, Hughes)

- Integrated residential array designs developed and optimized (AIA, GE)

- Array electrical characterization completed

- Array electrical safety investigation complete 


\section{SYSTEMS AND APPLICATIONS OVERVIEW HIGHLIGHTS OF SUBSYSTEM DEVELOPMENT (Cont'd)}

- Interim working guidelines for small dispersed PV Systems with utilities

- Completed advanced concept designs for PV power conditioners

- Assessment of state-of-the-art power conditioners for residential applications complete 


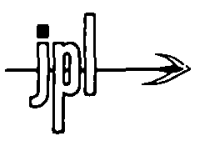

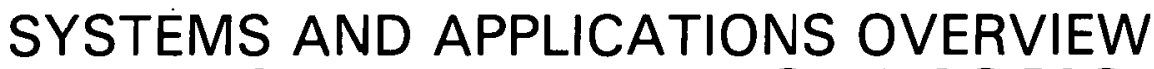 TESTS AND APPLICATIONS EXPERIMENT SUMMARY}

\section{APPLICATION}

Small, Roof-Integrated Systems

John F. Long House, AZ

Florida Solar Energy Ctr., FL

Northeast RES, MA

Southwest RES, NM

Carlisle, MA

Hawaiian Islands
NAMEPLATE

RATING, kW

4.9

5.0

25.5 (5 systems)

37.8 (8 systems)

7.1

8.0 (3 systems)
STATUS

First direct mounted roof

Performing as predicted

3 systems operational

4 systems operational

Operational: house to be sold, lived in

Recently installed 


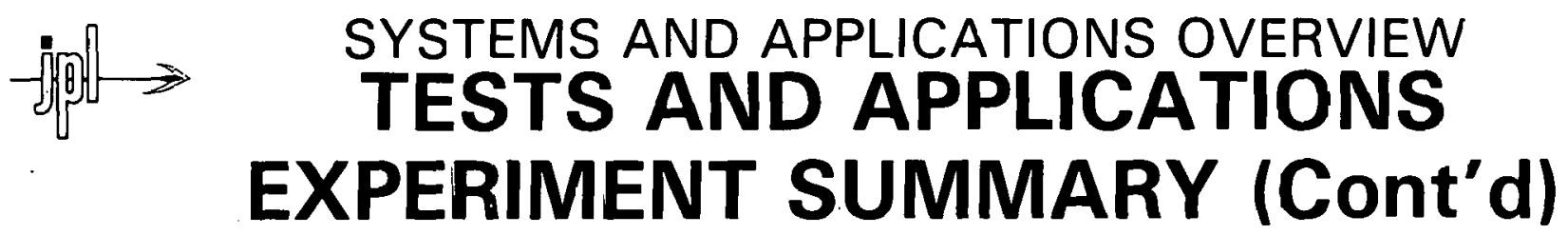

APPLICATION

NAMEPLATE

RATING, kW

STATUS

Medium-Size Systems (Majority Ground Mounted)

Dallas-Ft. Worth Airport, TX

BDM Bldg., Albuquerque, NM

Wilcox Hospital, Kauai

Sky Harbor Airport. Phoenix, AZ

El Paso Electric, TX

Oklahoma City Science, Art Ctr.

Shopping Ctr., Lovington, NM

High School, Beverly, MA

Light Mfg. Facility, San Berdno., CA

Mt. Laguna, Radar, CA

WBND Radio, Bryan, $\mathrm{OH}$

Agricultural, Mead, NE

Natural Bridges, UT

Miss. Cnty. Comm. College, AR

N.W. Miss. J.C., MS

Soleras, Saudi, Arabia
27.0

47.0

35.0

225.0

15.5

135.0

90.4

90.4

35.0

65.0

15.3

29.3

105.6

240.0

101.0

300.0
Operation expected July '82

Construction Phase;

Operations April '82

Testing began September ' 82

Operation expected June ' 82

Operational January ' 81

Operation expected March '82

Operational March '81

Operational April '81

Testing began September ' 81

Approx. 2 years operation

Approx. 2 years operation

4 years of operation

Full year of operation

Power lower than expected

Construction; operation

uncertain

Testing began September ' 81 


\section{SYSTEMS AND APPLICATIONS OVERVIEW TESTS AND APPLICATIONS EXPERIMENT SUMMARY (Cont'd)}

APPLICATION

Small Remote Systems

Indian Village, Schuchuli, AZ

Naval Center, China Lake, CA

Numerous, Remote
NAMEPLATE

RATING, kW

3.5

8.1

$0.07-0.33$
STATUS

Approx. 2-1/2 years operation

Over 4 years of operation

17 Installations - High

Reliability 


\section{SYSTIEMS AND APPLICATIONS OVERVIEW PROGRAM STATUS SUMMARY}

\begin{tabular}{|c|c|c|c|}
\hline & DEPARTMENT & APPLICATIONS & OPERATIONAL \\
\hline & AGRICULTURE & 332 & 20 \\
\hline & COMMERCE & 56 & 3 \\
\hline & DEFENSE & 218 & 23 \\
\hline & ENERGY & 52 & 1 \\
\hline$\stackrel{L}{N}$ & GENERAL SERVICES ADMINISTRATION & 1 & 0 \\
\hline$\tilde{z}$ & HEALTH \& HUMAN SERVICES & 249 & 2 \\
\hline & INTERIOR & 314 & 155 \\
\hline & STATE & 1 & 0 \\
\hline & TRANSPORTATION & 1457 & 8 \\
\hline & TREASURY & 1 & 0 \\
\hline & $\begin{array}{l}\text { ENVIRONMENTAL } \\
\text { PROTECTION AGENCY }\end{array}$ & 47 & 12 \\
\hline & $\begin{array}{l}\text { TENNESSEE VALLEY } \\
\text { AUTHORITY }\end{array}$ & 24. & 9 \\
\hline & TOTALS & 2752 & 233 \\
\hline
\end{tabular}




\section{SYSTEMS AND APPLICATIONS OVERVIEW CURRENT PROGRAM}

- Transition phase

- Mandated experiments

- Technology transfer

- Core systems program 


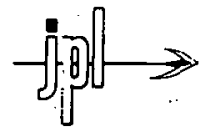

SYSTEMS AND APPLICATIONS OVERVIEW

TRANSITION PHASE

- Shift in emphasis to high-risk research and development

- Completion of contracted development tasks

- Closeout of DOE participation in system-level testing

- Effect technology transfer

- Establish Core Systems Program 


\section{SYSTEMS AND APPLICATIONS OVERVIEW MANDATED EXPERIMENT SET}

- 100-MW Photovoltaic Power Plant (First

$1 \mathrm{MW}$ ) Sacramento Municipal Utility

District

- Higher Education Exemplar Photovoltaic Facility Georgetown University

- Southeast/Residential Experiment Station 


\section{SYSTEMS AND APPLICATIONS OVERVIEW CORE SYSTEMS PROGRAM}

- Overall AR\&D Allocation Guidelines

- Advanced Systems Options.

- System Interface. Definition

- Advanced Technology Performance Evaluation 
SYSTEMS AND APPLICATIONS OVERVIEW

TECHNOLOGY TRANSFER

- Design Overview

- Topical Reports

- Design Handbooks

- Candidate Designs

- Test Results

- Workshops 
MIT LINCOLN LABORATORY INTERMEDIATE-SIZE FIELD EXPERIMENTS FATURAI, BRIDGES NATIONAL MONUMENT PHOTOVOLTAIC SYSTEM

\author{
F. J. Solman, III \\ Massachusetts Institure of Technology \\ Lincoln Laboratory \\ Lexington, Massachusetts 02173
}

A large, stand-alone photovoltaic (PV) power system with energy storage has been in operation since June 1980 at Natural Bridges National Monument in southeastern Ltah. Operating results for the system are in substantial agreement with simulations done before construction. Measured data are now available for the battery performance over this period. The design cunsiderations and how they were realized are reviewed as are the departures from predicted performance.

The goal of this project is to demonstrate the technical feasibility of a large PV system in a remote stand-alore application. The system is providing experience in solving a number of the problems in supporting sich a system in a remote location. These include documentation of the system and its performance, training aids for operators and maintenance personnel, and the introduction of a local radio service shop as a maintenance contractor. Good telephone liason between National Park Service personnel and technical support personnel for the system has solved many minor system malfunctions.

Table I lists an operating time summary for the NBNM system since June 1980. During 17 months of continuous operation, the PV system unscheduled downtime amounted to approximately $7 \%$ of the total operating period. The inverters have been responsible for almost all unscheduled system downtime.

Almost all of the scheduled dowrtime of the PV system was due to battery specific gravity readings. For safety reasons, these are done with the battery off-line and the PV system shut down. During the first six months of operation, measurements were taken after each battery equilization. In recent months specific gravity measurements have been made less frequently.

In Table II it will be noted that the sum of the energy produced by the diesel generator and the PV system is greater than the load. This is due to the energy required for battery equilization and the efficiency of the battery charger battery and main inverter.

The heating and cooling of the PV building places an overhead load on the PV power system. This load averages about $11 \%$ of the site load and has been higher in the summer months due to cooling-blower energy requirements. In winter, waste heat is used to heat the building and large fans are used only to dump excess heat outside as required.

Table III presents a summary of average efficiencies measured during the period JuIy 1980 to Octuber 1981 .

Before measured data were actually acquired at the NBNM site, the PV power system was sinulated on a computer using analytical models of the array, battery, auxiliary power and inverter. Figure 1 presents a comparison between simulated monthly load data and actual load data collected at NBNM during the January chrough July 1981 time period. According to the results of the simulation, the actual loads measured during this time interval should fall into the low load region, except for the January load. (The January load is categorized as a medium.) A load 1s designed as a low load if it is never necessary to use the auxillary power to boos: the battery state of charge (SOC). During the months of February through July, the auxiliary power was never used to boost the battery SOC (it was used only for equalization). in January, however, auxillary power was occasionally used to boost the SOC as well as for equalization. Thus, January fits into the defintition of medium load.

*Th1s work was sponsured by the U.S. Department of Energy.

tihe U.S. Government assumes no responsibility for the work presented.

HSubmitted to the Third Photovoltalc Systems and Applications Project Integration Meeting,

9-11 February 1982, Albuquerque, NM. 
TABLE I

OPERATING TIME SUMMARY

$\begin{array}{lrrr} & 1980 & 1981 & \text { Total } \\ \text { Total Months } & 7 & 10 & 17 \\ \text { Total Hours } & 5179 & 7320 & 12,499 \\ \text { PV System } & 80 & 99 & 91 \\ \text { Diesel Generator Use } & 26 & 8 & 16 \\ \text { Battery } & & & 0.8 \\ \text { Boost } & & 0.6 & 7 \\ \text { Equal. } & 0.3 & 6.6 & 7 \\ \text { Site } & 8 & & 1 \\ \text { Unsched. } & & 0.1 & \\ \text { Sched. } & 17 & 1.1 & \end{array}$

*Figures are given as $\%$ of total hours in period. 
TABLE II

AC ENERGY SUMMARY

1980

54499

Sitc Ac Load (kWh)

Diesel Generation*

PV System Generation *

PV Building Load ${ }^{*}$

UPS Load*

*As percent of site ac load
77

8
1981

Total

67454

16

99

11

8
120844

23

90

11

8 
TABLE III

MEASURED AVERAGE COMPONENT AND SYSTEM ENERGY EFFICIENCIES

(July 1980 through October 1981)

Average Value

(\%)

Battery Charger

Main Inverter

UPS Inverter

Battery $^{*}$

Array ${ }^{+}$

System $^{++}$
85

75

61

85

5.4

67
Variation

(\%)

$\pm 1$

$+4$

$+3$

$\pm 5$

$\pm 1.3$

$\pm 4.5$

* Battery efficiency is the ratio of energy released on all discharges to the energy stored on all charges.

+ Array efficiency is the ratio of the solar energy falling on the cell area to the array dc-energy output. Due to shedding, this efficiency is less than the cell efficiency and will vary seasonally and with the site load.

++System efficiency is defined as ac-load energy delivered

by the UPS and main inverters to the dc energy generated by the array and battery charger. 


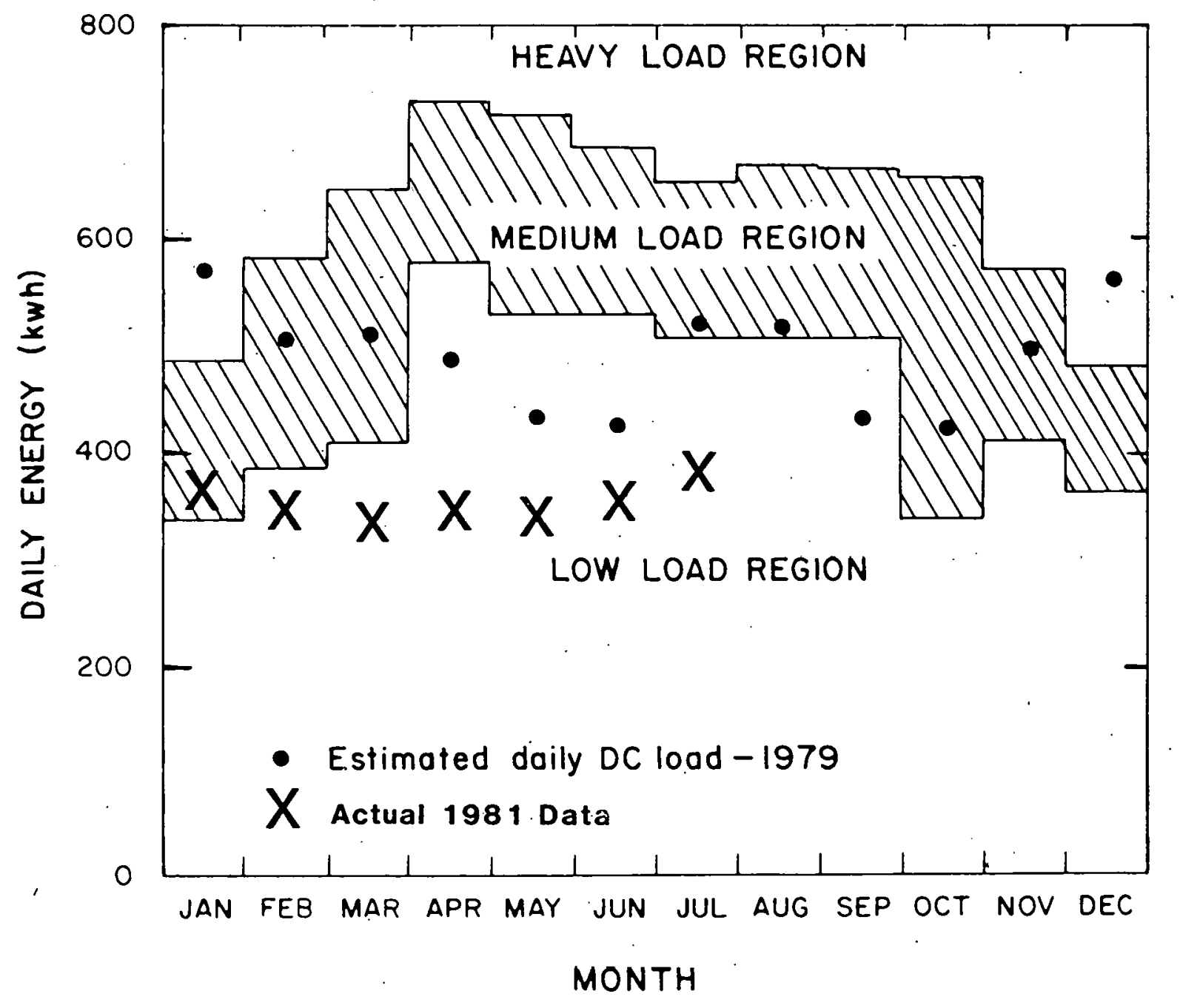

Fig. 1. Monthly load category boundaries and actual loads. 


\section{Abstract}

DOE PHOTOVOLTAIC GRANT PROJECTS

S. I. Kaplan, ORNL

ORNL coordinates technical assistance and provides technical monitoring for three photovoltaic (PV) projects funded by DOE grants: Mississippi County Community College (MCCC), Northwest Mississippi Junior College (NMJC) and Georgetown University (GU). Post-startup testing is now underway at MCCC; the power output in November reached about $45 \%$ of design rated output after correcting for seasonal variations. Considerable additional improvement is anticipated as optical alignment is further adjusted and malfunctioning diodes are identified and replaced. Optical reflectivity is also a limiting factor.

The startup of the NMJC project is presently under review by the school, and all work is presently suspended. Erection of the PV components is incomplete and none are now in service.

The GU Intercultural Center building, which will support the rooftop PV array, is erected and undergoing interior finishing. The RFP for design and erection of the $\sim 300 \mathrm{kWp}$ PV system was issued on December 11, 1981, and bids will be opened January 31, 1982. 
THERE ARE THREE DUE PHOTOVOLTAIC GRANT PROJECTS:

* ILC SIZE

* associated with higher educational INSTITUTIONS

* \$5-8 MILLION RANGE

* WIDELY VARYing STAGES UF COMPLETION 


\begin{tabular}{|c|c|c|c|}
\hline PROJECT & $\begin{array}{l}\text { PV CELLS AND } \\
\text { CONCENTRATION }\end{array}$ & $\begin{array}{l}\text { DESIGN } \\
\text { OUTPUT }\end{array}$ & STATUS \\
\hline $\begin{array}{l}\text { MISS. COUNTY COMMUNITY } \\
\text { COLLEGE (MCCC) } \\
\text { BLYTHEVILLE, ARK. }\end{array}$ & SI $40 x$ & $240 \mathrm{~kW}$ & $\begin{array}{l}\text { COMPLETE IN START- } \\
\text { UP PHASE }\end{array}$ \\
\hline $\begin{array}{l}\text { NORTHWEST MISS. JUNIOR } \\
\text { COLIEGE (NMJC) } \\
\text { SENATURIA, MISS. }\end{array}$ & $\begin{aligned} & \text { CDS/CUS Ix } \\
& \text { SI } 5 x \\
& \text { - SI } 40 x \\
& \text { GAAS } 400 x\end{aligned}$ & $\begin{array}{l}1 \\
50 \\
50 \\
50\end{array}$ & PROJECT SUSPENDED \\
\hline $\begin{array}{l}\text { GEORGETOWN UNIVERSITY (GU) } \\
\text { WASHINGTON, D.C. }\end{array}$ & SI $l x$ & 300 & $\begin{array}{l}6 \text { BIDUERS SELECTED } \\
\text { RFP FOR DESIGN } \\
\text { AND POSSIBLE CON- } \\
\text { STRUCTION TO BE } \\
\text { ISSUED ON DEC. } \\
\text { I981 }\end{array}$ \\
\hline
\end{tabular}




\section{MISSISSIPPI COUNTY COMMUNITY COLLEGE · MCCC)}

ITS IA AR SOLAR PV SYSTEM FEATURES INCLUDE:

* N-S PARABOLIC TROUGHS 3OX (NET)

* SINGLE CRYSTAL Si IN 703-CELL STRINGS

* $240 \mathrm{~kW}$ AT 845 W/M2 (AUGUST DESIGN DAY)

* $11.5 \times 10^{6}$ BTU/DAY (JANUARY DESIGN DAY)

* UTILITY GRID-INTERACTIVE 
THE STATUS OF MCCC IS:

* PRESENTLY UNDERGOING POST-STARTUP TESTING AND ADJUSTMENT

* PROVIDING USEFUl GENERIC EXPERIENCE IN:

REFLECTOR CONSTRLCTION AND TESTING

RECEIVER CONSTRUCTION AND TESTING

TRACKER HEAD REQUIREMENTS FOR CLIMATES WITH HIGH INDIRECT INSOLATION FRACTION 


\section{NMU}

GRANT AWARUED

BIOIASS BUILER ANU HEATING LOOP BUILT \& TESTEU

$12 / 80$

LAST PV ARRAY ERECTION ACTIVITY

$2 / 81$

TEAM OF VIRGIHIA, INC. SOLU TO NATIONAL ENERGY TECHNOLOGY IHC.

$4 / 81$

NINC GRAHT EXPIRED

$5 / 31 / 81$

NHIJC'BUARE VOTES TO TRAMSFER RESIDUAL GRAHT

FUNUS INTO NEW CO-OP AGREENENT WITH DOE

$7 / 27 / 81$

NEW UUE/NMIJC COOPERATIVE AGREEIIENT SUBMITTED

TU INUC FOR APPROVAL

$9 / 24 / 81$

NHIC DECLINES COUPERATIVE. AGREEMENT, THUS LOSING ACCESS TO FY-1981 FUNDS

$9 / 30 / 81$ 


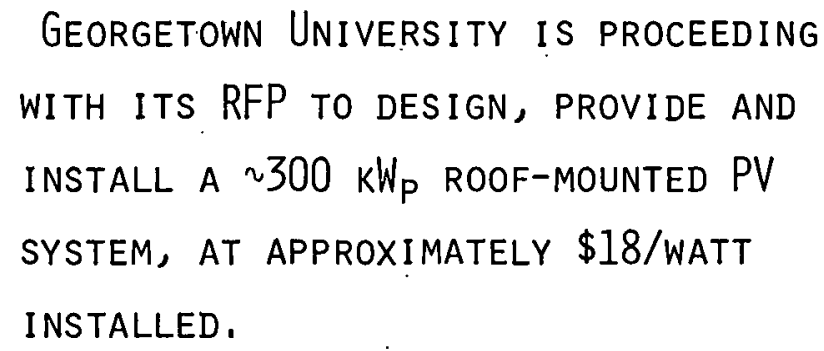

BIDS ARE DUE BY JANUARY 31, 1982.

Cóntract award is expected on April 30. 
PAPER NOT AVAILABLE AT TIME OF PRINTING 
PAPER NOT AVAILABLE AT TIME OF PRINTING 
THE EL PASO 20-KIJ,OWATT SYSTEM OPERATION

\author{
V. Vernon Risser \\ New Mexico Solar Energy Institute \\ Box 3 SOL \\ Las Cruces, NM 88003
}

This 20-kilowatt, flat-plate photovoltaic system was designed, constructed, and integrated onto an existing uninterruptible power supply (UPS) at E1 Paso Electric Company's Newman Power Station, E1 Paso, Texas. The New Mexico Solar Energy Tnstitute (NMSEI) is prime contractor.

The system consists of 64 parallel-connected panels, each panel containing nine series-connected modules. The 279 square meters of panels face due south and are tilted at a fixed 26 degrees from horizontal. The electrical output from the array is supplied directly to the load at a fixed voltage of 134 volts dc.. The PV system, operating unattended since January 1981, provided more than 32,000 kilowatt-hours to the load during the first year.

As part of the Phase III contract, NMSEI is collecting and analyzing system performance data, conducting special testing, and supporting El Paso Electric in system maintenance. Special tests and analyses are underway on the economic feasibility of array washing, the suitability of fixed voltage operation for this application, and the intrastring voltage variation across the individual modules: These results will be dịcussed.

Records of all system maintenance have been kept and analyzed. They show that reliability of prime system components has been high, but the reliability of the data acquisition system needs to improve. The number of required maintenance "interventions" for each subsystem will be presented. 
EL PASO PV SYSTEM

MILESTONES

- PHASE I CONTRACT

- PHASE II cONTRACT

- PHASE III CONTRACT

- CONSTRUCTION STARTED

- panel fabrication complete

- FIRST SYSTEM TEST

- aUtOMATIC OpERATION.

- PASSED 10 MWH MARK

- PASSED 20 MHiH MARK

- PASSED 30 MWH MARK
OCTOBER 1978 - HARCH 1979 OCTOBER 1979 - MAY 1981 JUNE 1981 - MAY 1983 JUNE 2,1980 OCTOBER 3, 1990 DECEMBER 4, 1980 JANUARY 27, 1981 MAY 22, 1981 SEPTEMBER 4, 1981 DECEMBER 30, 1981 


\section{EL PASO PV SYSTEM}

\section{PV ARRAY}

- $278 M^{2}$ PANEL AREA

- 168 $M^{2}$ ACTIVE SILICON AREA

- FIXED $26^{\circ}$ TILT - DUE SOUTH

- 64 PARALLEL-CONNECTED STRINGS

- 9 SERIES-CONNECTED MODULES PER STRING

- FIXED VOLTAGE OPERATION - 135 VOLTS

- 150 AMPERES MAXIMUM 


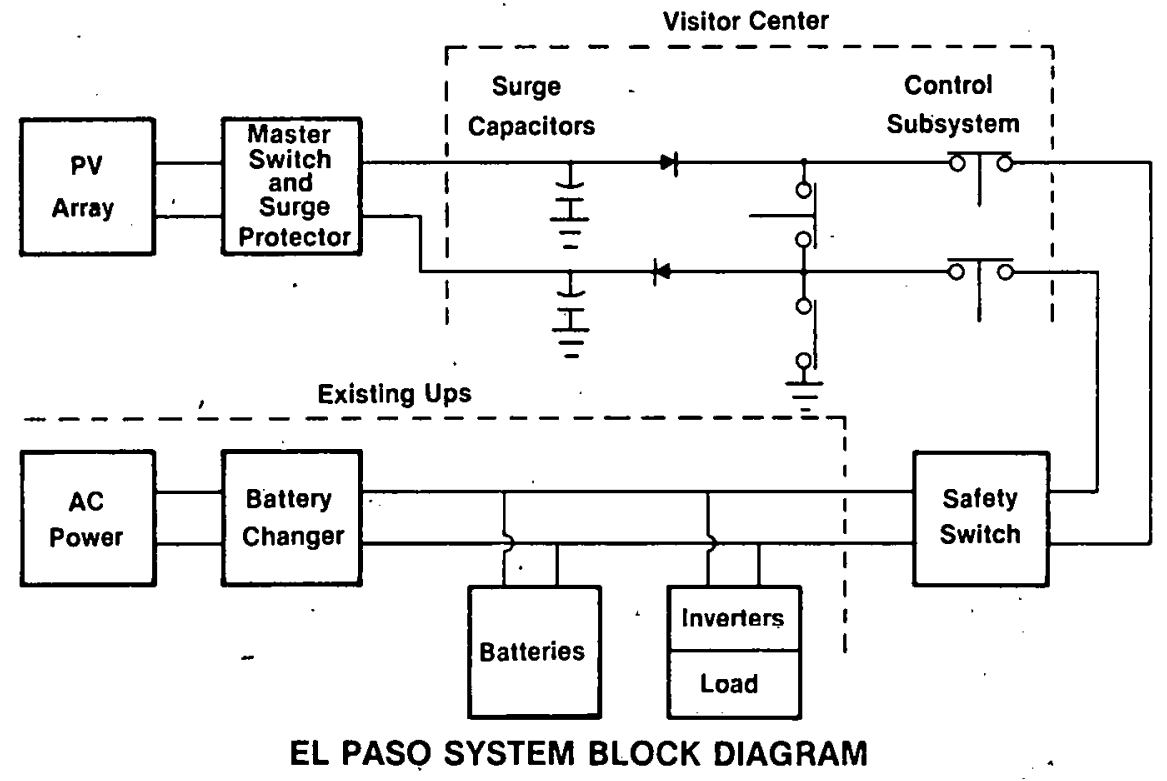




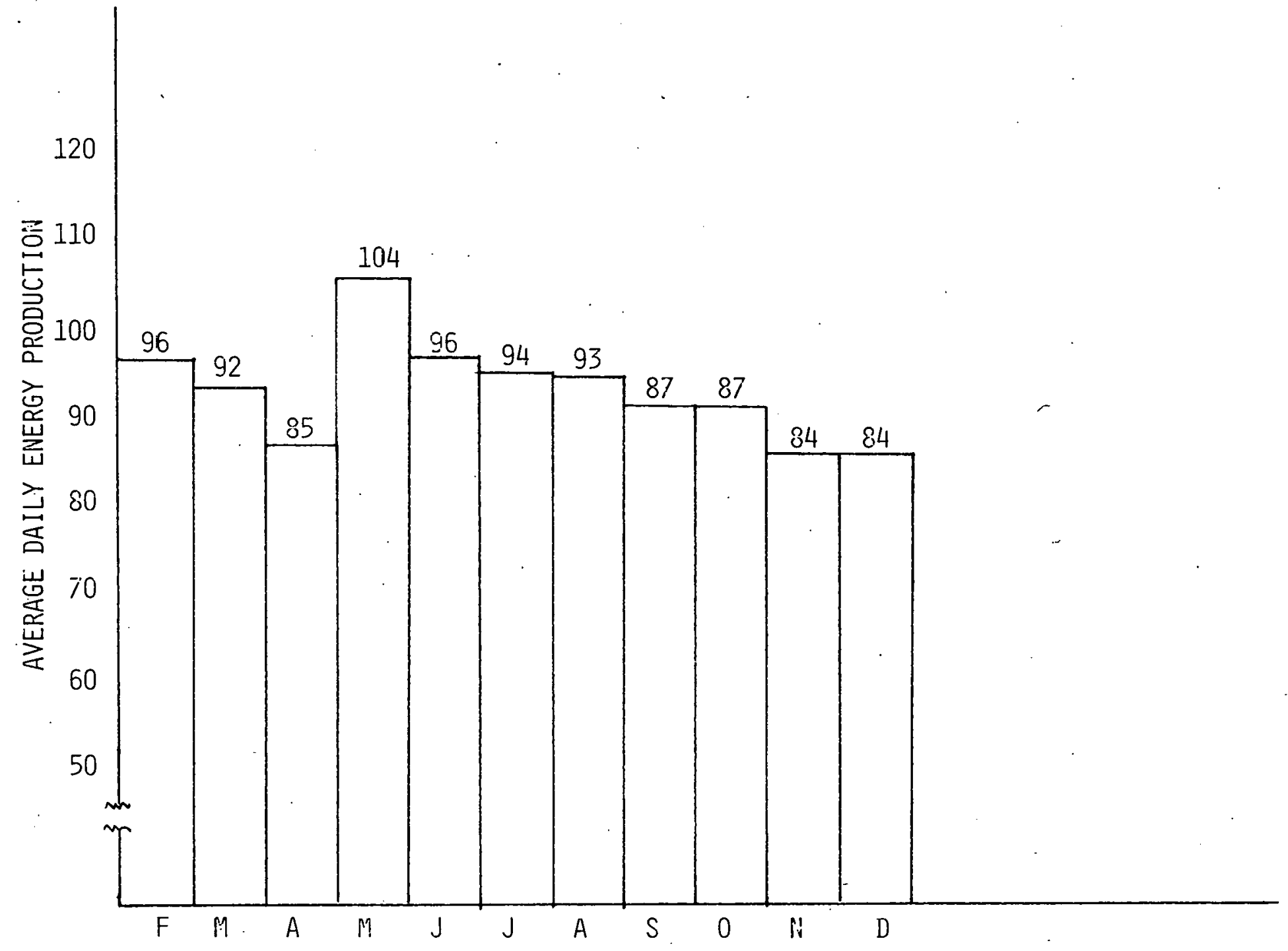




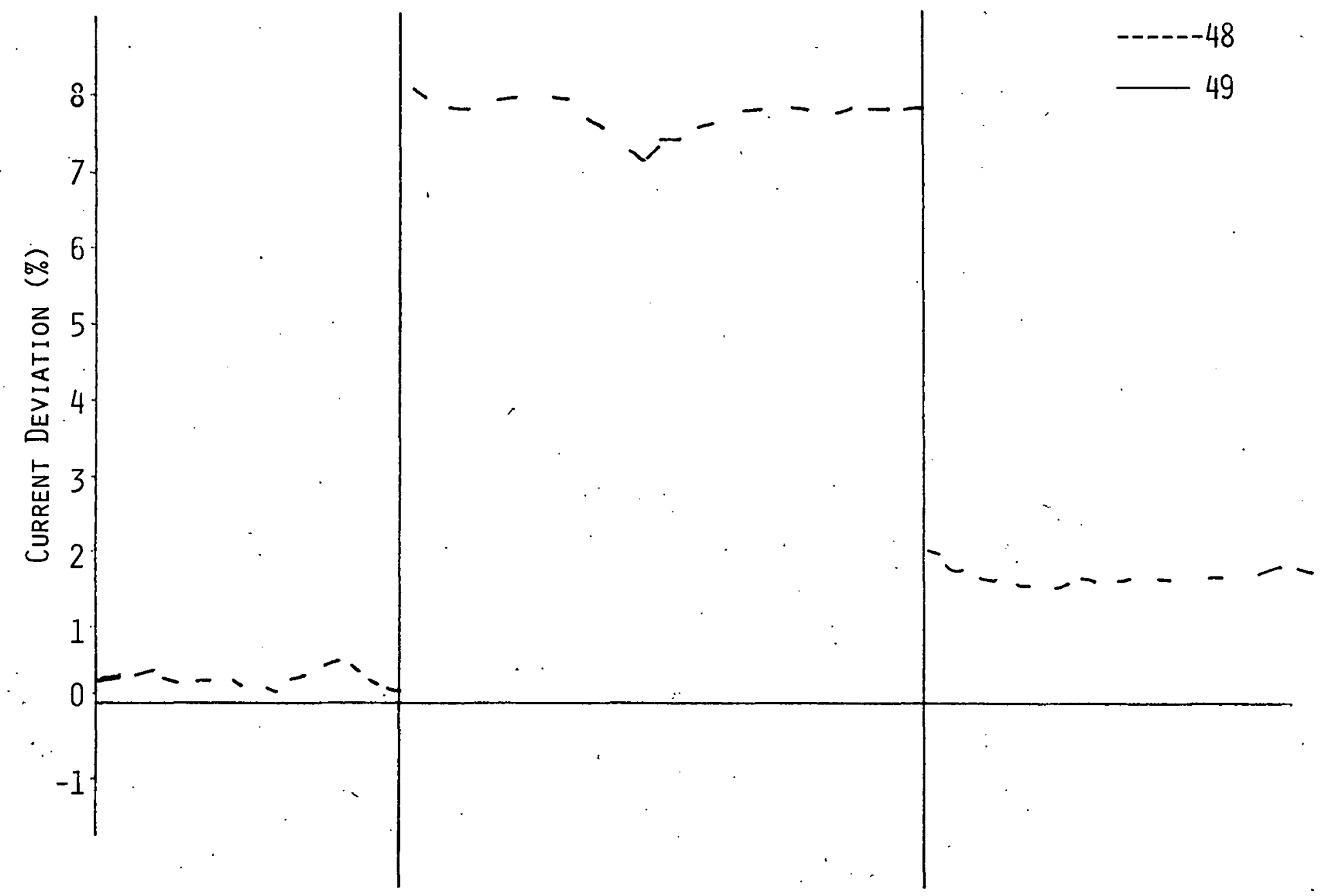

$\begin{array}{lllllllll}11 / 1 & 11 / 6 & 11 / 12 \quad 11 / 16 & 11 / 21 & 11 / 26 & 12 / 1 & 12 / 6 & 12 / 11 \\ & & & & \text { RaIN } & & & \\ \text { WARAY } & & & & & & & & \end{array}$




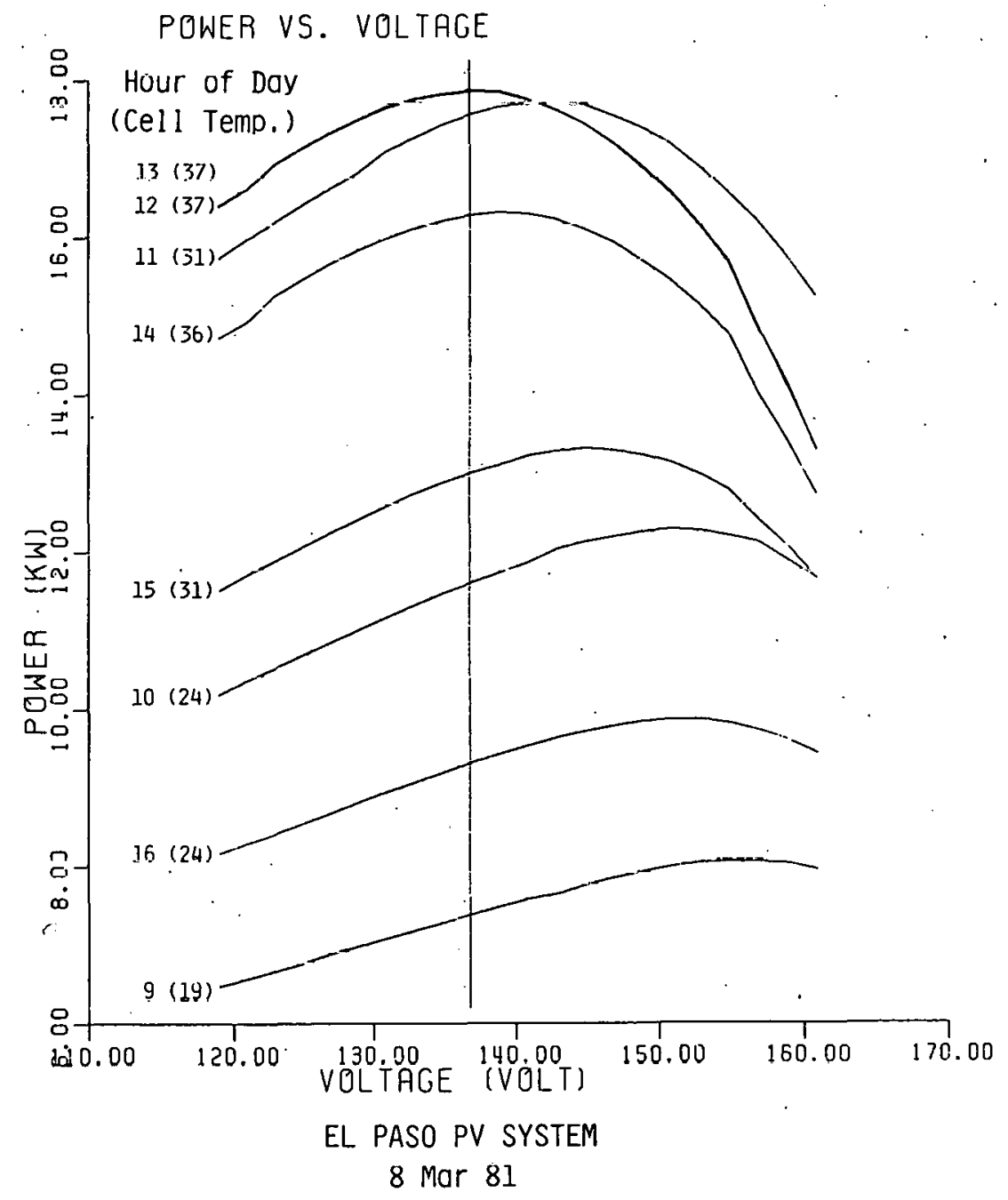




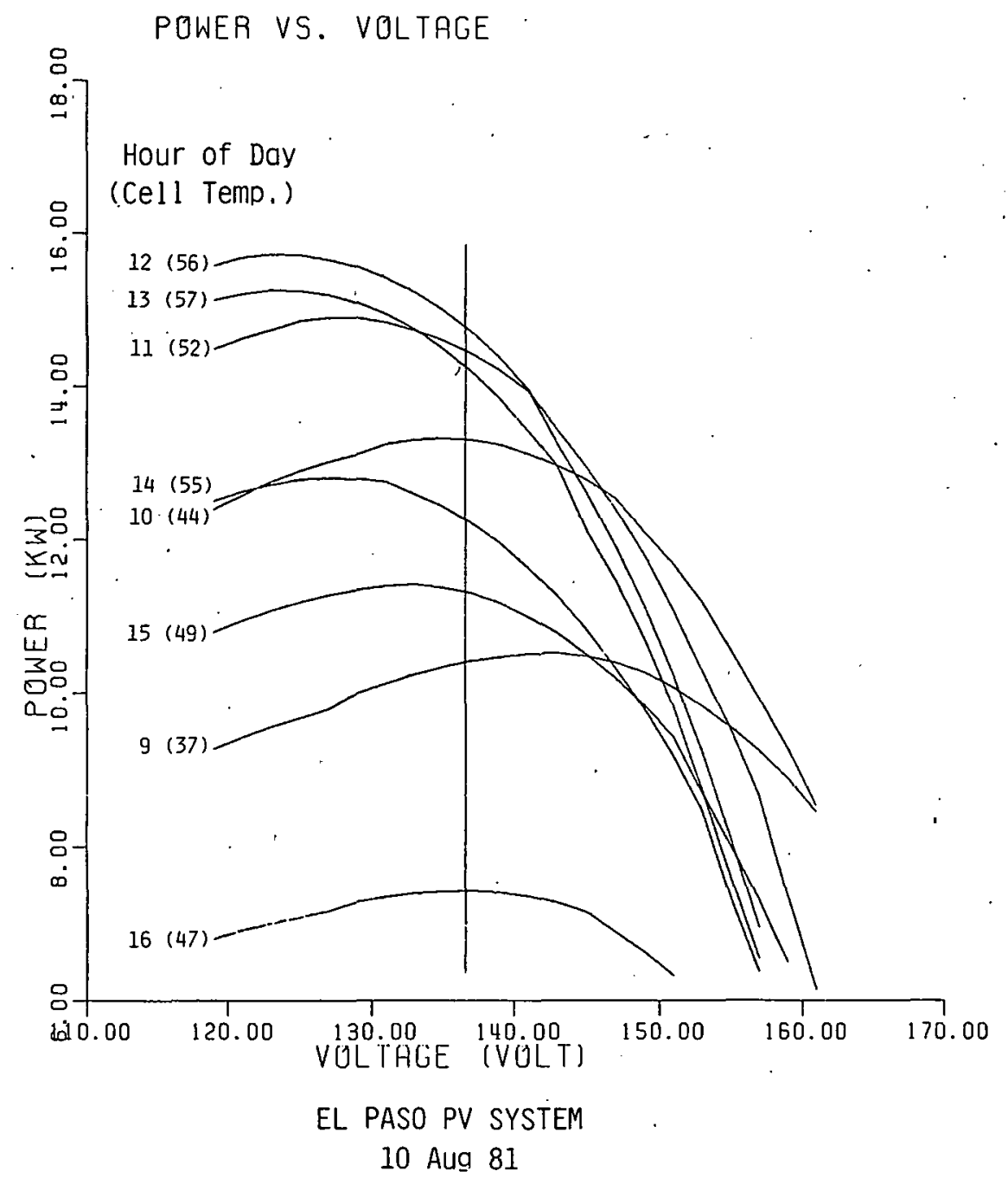



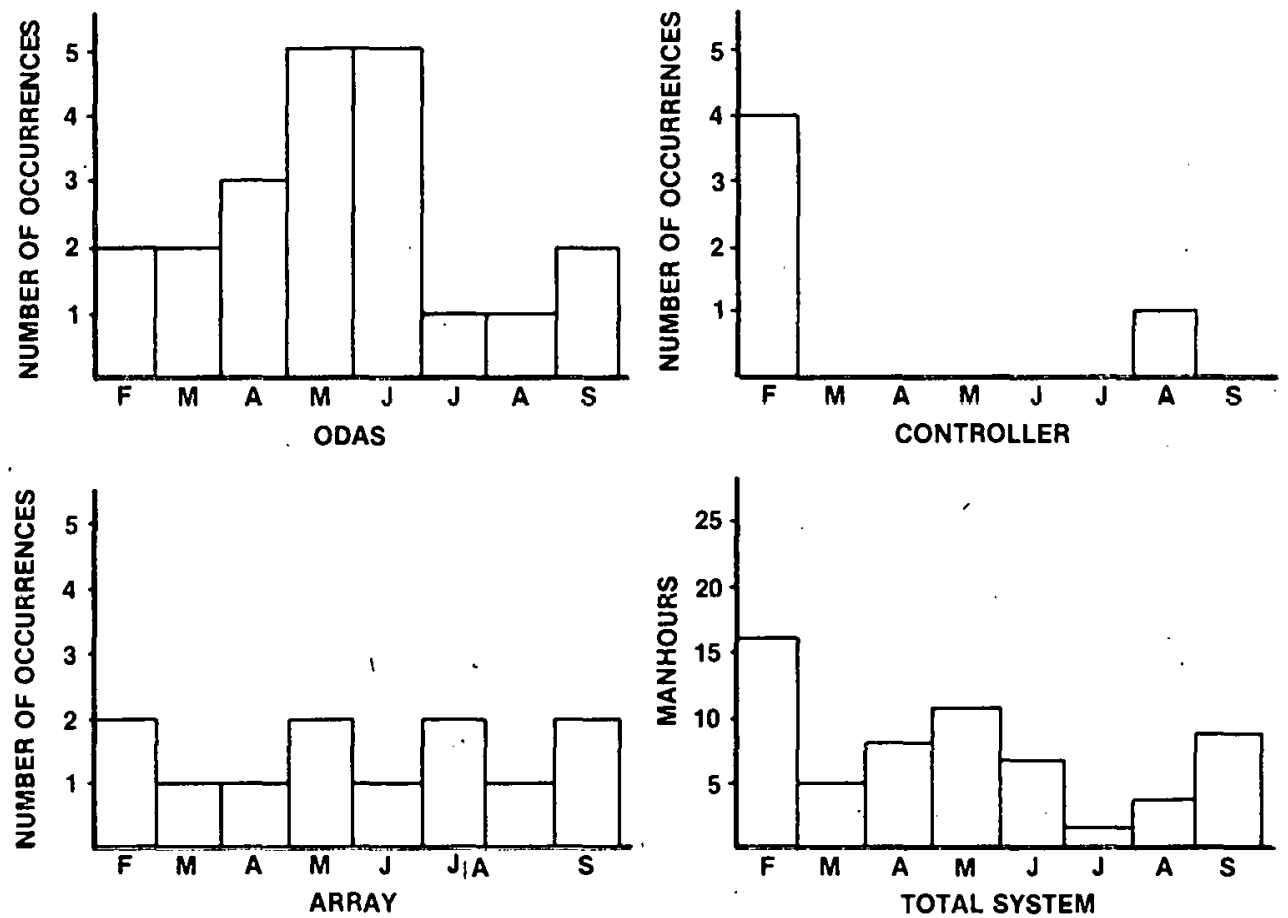

EL PASO SYSTEM MAINTENANCE ACTIVITY 


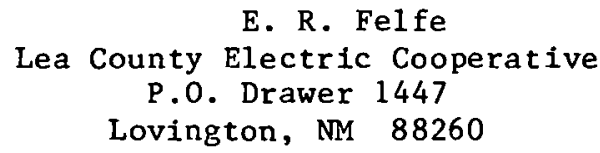

\author{
V. Vernon Risser \\ New Mexico Solar Energy Institute \\ Box 3 SOL \\ Las Cruces, NM 88003
}

A 100-kilowatt flat-plate grid-connected photovoltaic system has been installed in Lovington, New Mexico, and has operated automatically since March 17, 1981. The system consists of two 50-kilowatt subfields, each with a dedicated power conditioning unit. Each subfield contains 21 subarrays, with each subarray having 16 series-connected groups of 5 modules connected in parallel. Oriented due south, the total panel area of 1,685 square meters may be adjusted manually to 10 , 30 , or 40 degrees from horizontal.

The output of the array is inverted to 480 volts $3 \phi$, transformed to 12,480 volts and applied to the Lea County Electric Cooperative power grid. The primary user is the Lovington Square Shopping Center located just 0.3 miles east of the array. The system is expected to provide 8 percent of the annual energy requirements of the shopping center.

System performance and weather information is collected and analyzed by New Mexico Solar Energy Institute, where performance data is checked daily and fault detection techniques are used if string current degradation is noted. System operation and maintenance are performed by Lea County Electric Cooperative. The reliability of the prime system components has been high. Maintenance requirements have been low and are decreasing on all subsystems except the data acquisition sys tem.

Since August 1981, the two subfields have been operated at different angles--one at 30 degrees and the other at 40 degrees. The diffexence in energy production is being monitored and will be used as a basis to determine the economic feasibility of periodically adjusting the panel tilt. This data and other experience gained from the first year of operation will be discussed. 
THE LOVINGTON $100 \mathrm{KII} \mathrm{PV} \mathrm{SYSTEM}$

\section{MILESTONES}

- GROUNDBREAKING

- FOUNDATIOINS COMPLETED

- underground CABLing COMPLETED

- panel installation completed

- pCU installation

- INSTRUMENTATION SYSTEM

- INITIAL SYSTEM TESTING

- initial enERgization

- system dEDICATION

- PASSER 100.0ก0 KWH MARK
15 AUGLST 1930

15 OCTOBER 1980

30 OCTOBER 1930

15 NIOVEMEER 1980

1 MARCH 1981

15 MARCH 1981

FEBRUARY-MARCH 1981

1.7 MARCH 1981

5 MAY 1981

20 SEPTEMBER 1981 
THE LOVINGTON 100 KW PV SYSTEPI

PV SUBSYSTEM

- $50 \mathrm{KW}$ SUBFIELD

$842 M^{2}$ MODULE AREA

$490 M^{2}$ ACTIVE SILICON AREA

21 SUBARRAYS IN PARALLEL

30 MODULES

SP $X$ I6S ELECTRICAL CONNECTION

220 - 260 VOLTS DC

230 AMPS MAXIMUM 


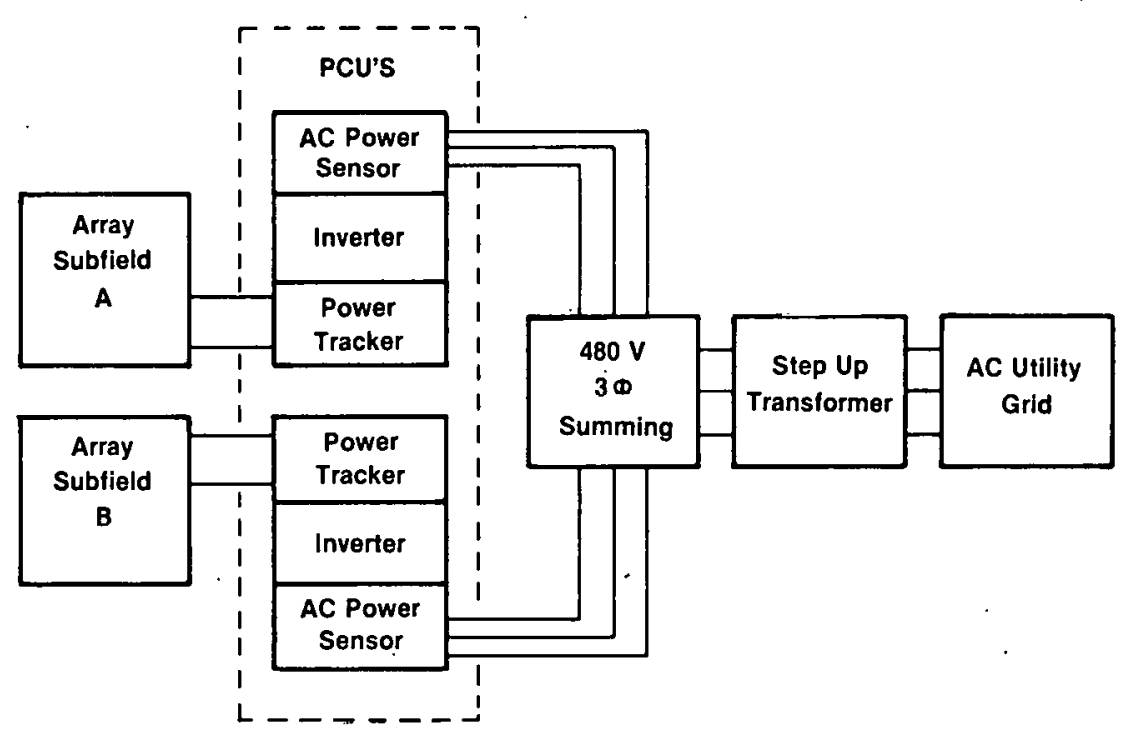

LOVINGTON SYSTEM BLOCK DIAGRAM 


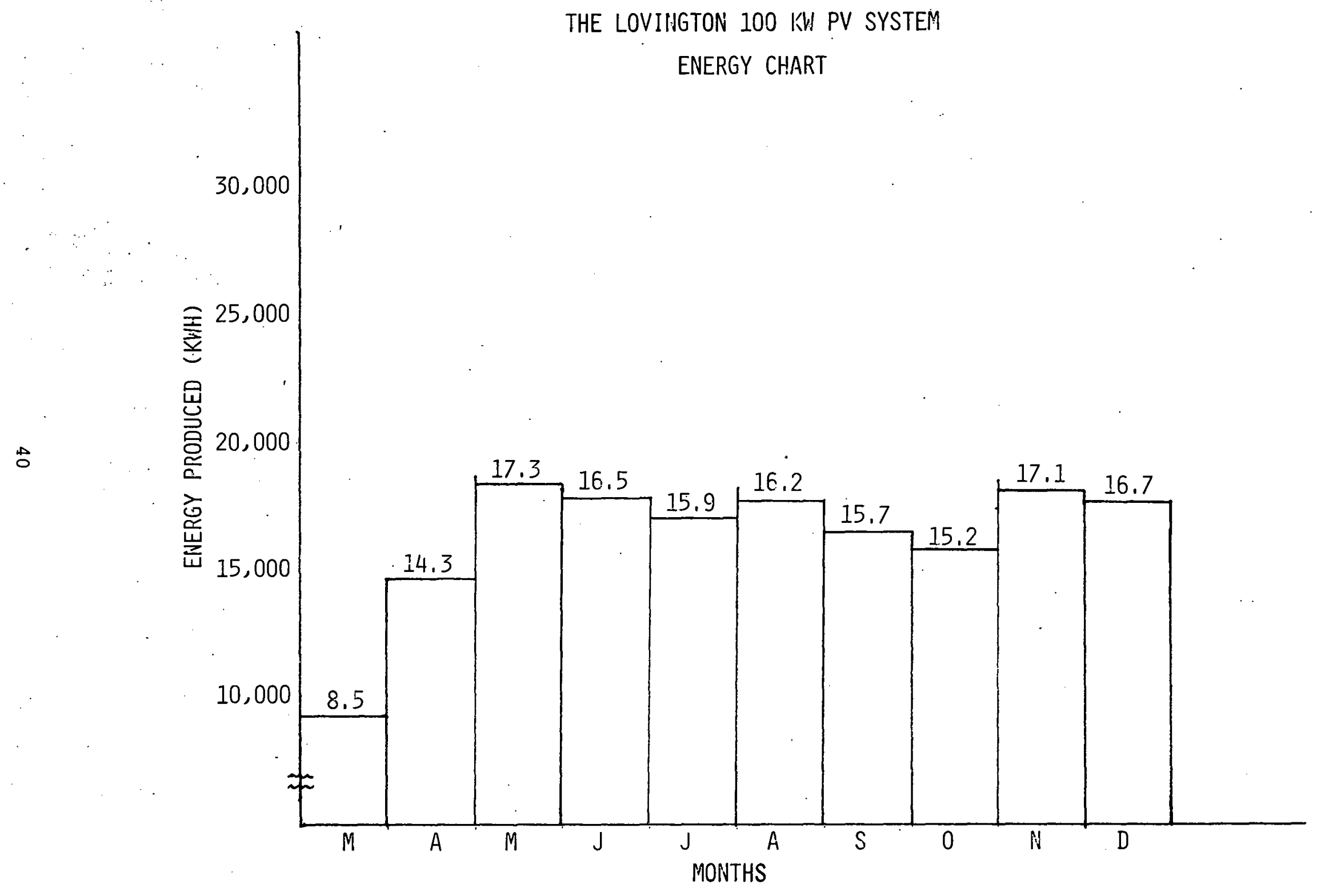




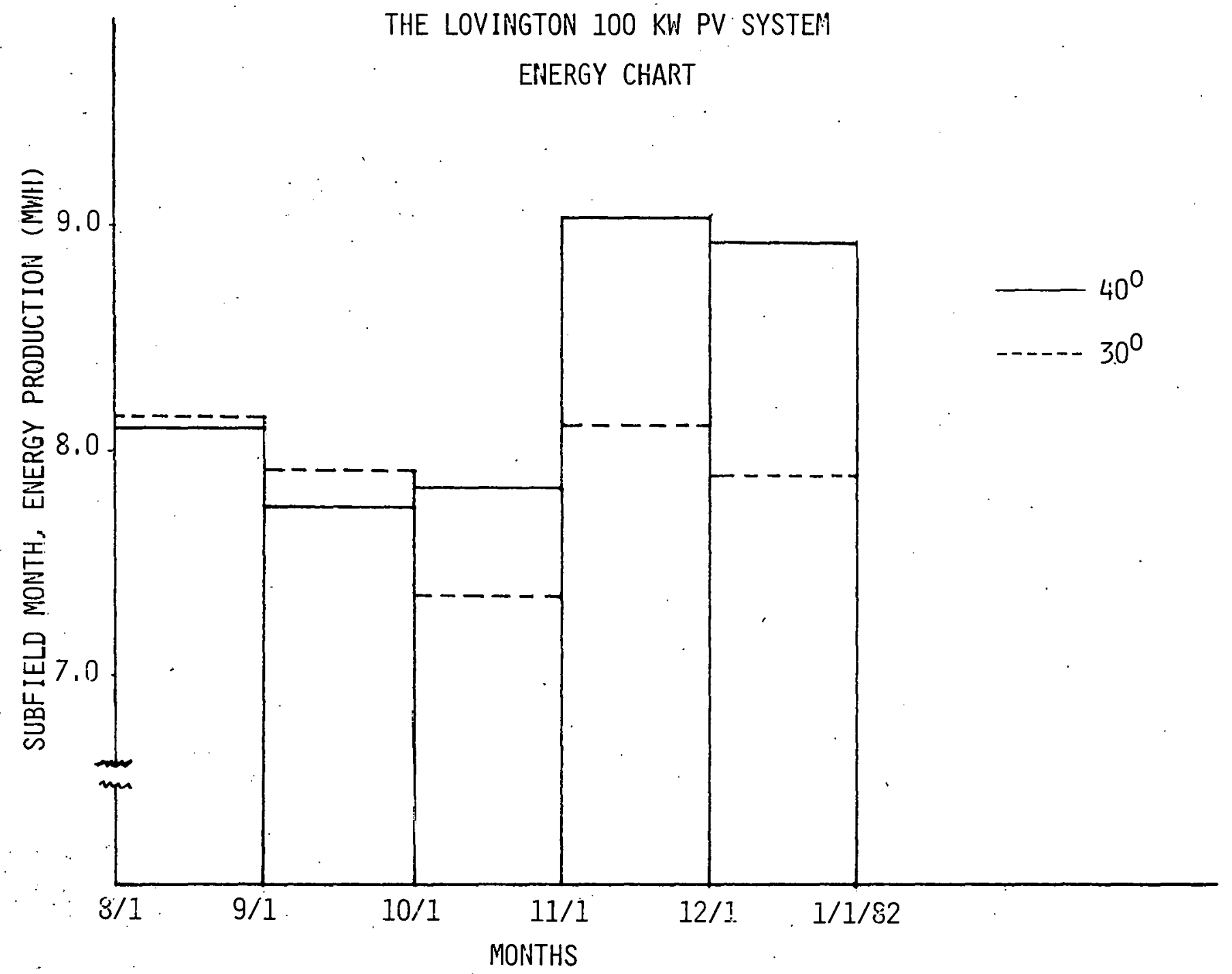




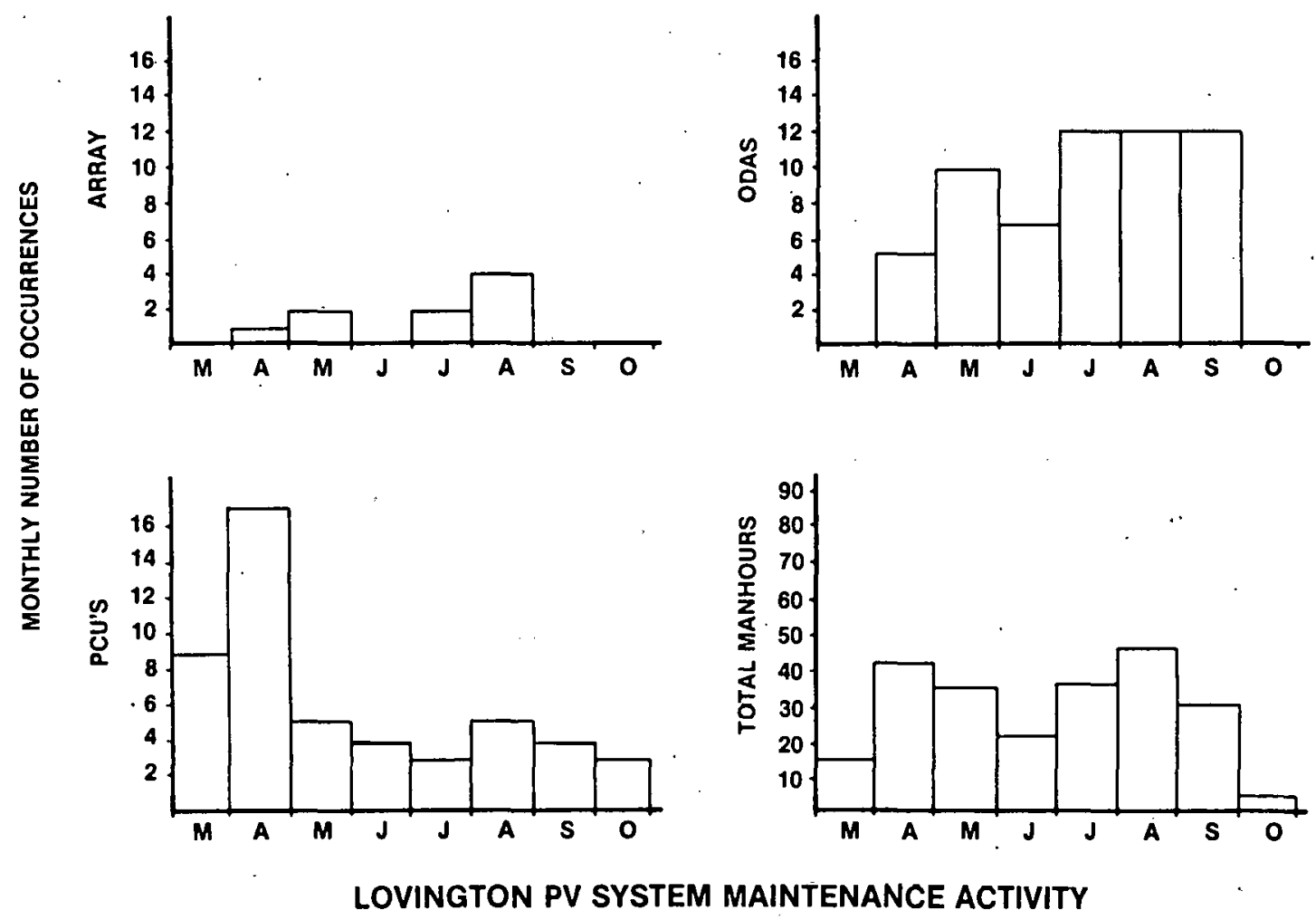


R.R. Addiss, Jr, and F.J. Marchese

Solar Power Corporation

20 Cabot Road

Woburn, MA 01801

This system was first energized in February of 1981. Following a two month period of checkout and debugging, the system became operational. As of December 14th, a total of $53.44 \mathrm{MWh}$ of $\mathrm{AC}$ energy have been produced. Of this, $2.40 \mathrm{MWh}$ were sold to the utility, all of which was generated during the summer.

Except fur a defective circuit which developed in one of the two inverters, resulting in its outage for most of two months, the system has performed as designed. A detailed analysis of one typical day's energy output profile showed an almost exact match between the actual system output and that predicted from a computer simulation model. Inputs to the simulation model included the performance specifications of an average module, the total number of modules, the specified inverter efficiency characteristics, and the actually measured values of cell temperature and insolation on a tilted surface. Only one such analysis of a typical day output profile has been done to date because it involves changing the computer program, with resultant loss of data, and because Phase III plans for detailed computer analyses have not been implemented yet. However, compilation of meter data over an extended period (mid August to mid December) shows the average operating DC power level to be $43 \mathrm{~kW}$. Considering that this average includes total operating t1me from dawn to dusk, fair weather and foul, $43 \mathrm{~kW}$ average is about what one might expect from a system rated $100 \mathrm{~kW}$ peak. The system performance simulation carried out during the Phase I contract predicts an average power of about $40 \mathrm{~kW} \mathrm{during}$ this period. The average inverter efficiency during this same period was $83.4 \%$ compared to a predicted $83.3 \%$. However, total system operating hours averaged on 1 y $56 \%$ of the predicted number, and this "downtime" completely accounts for the less than expected system output.

The main problem responsible for the reduced operating time is the tripout of inverters due to ground fault signals. As a safety feature, automatic shut down upon defection of excessive ground leakage current was included in system design. But experience slows that most, if not all, tripouts are caused by sporadic. ground current pulses of unknown origin rather than by true ground leakage. Because manual reset is required, inverters may be shut down for days before site personnel become aware of a tripout and effect a restart. This situation is clearly unacceptable, and ways to circumvent this problem without compromising safety are under investigation. 


\section{REVIEW OF PROJECT HISTORY}

\section{PHASE I - DESIGN \\ System Design and Performance Simulation:}

PHASE II - INSTALLATION

Design Modifications and Construction Plans:

FULL AUTHORIZATION TO INSTALL SYSTEM:

Site Activated:

SYSTEM ENERGIZED:

Checkout, Debugging, Verification of Operation:

SYSTEM Fully OPERATIONAL:

Total AC Energy Produced (12/14/81): $53.44 \mathrm{MWH}$

Total SOLd to Utility: $2,40 \mathrm{MWH}$
Ост, 78 - MaY 79

$$
\begin{aligned}
& \text { OCT, } 79-\text { JULY } 80 \\
& \text { AUGUST 4, } 1980 \\
& \text { AUgUST 15, } 1980 \\
& \text { FEBRUARY 11, } 1981 \\
& \text { MAR. } 81-\text { MAY } 81 \\
& \text { JUNE } 1981
\end{aligned}
$$

\section{PHASE III - OPERATION AND EVALUATION}

BEgIN:

DeCEMBer 1, 1981 


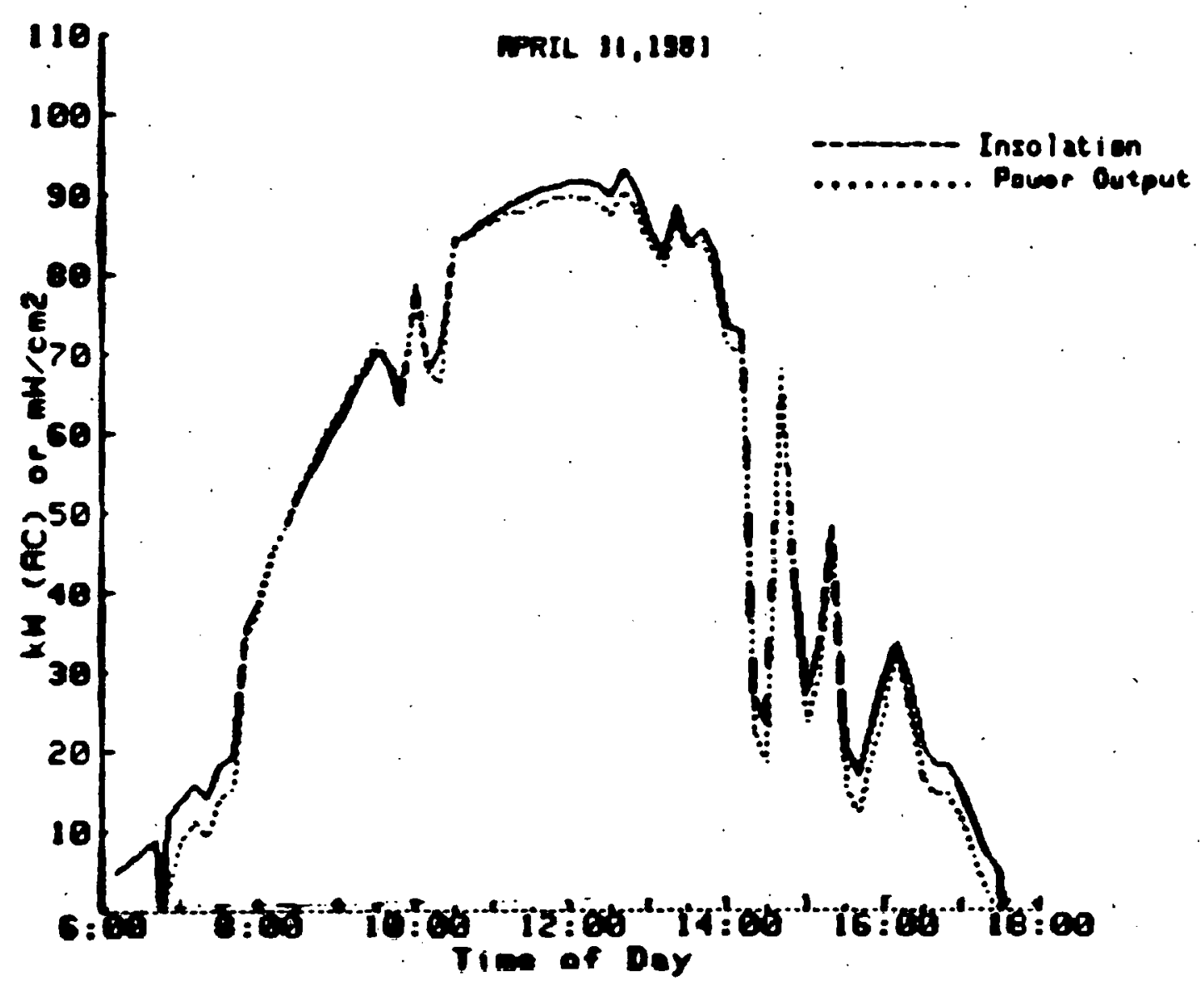

SYSTEH OUTPUT - IYPICAL DAY 


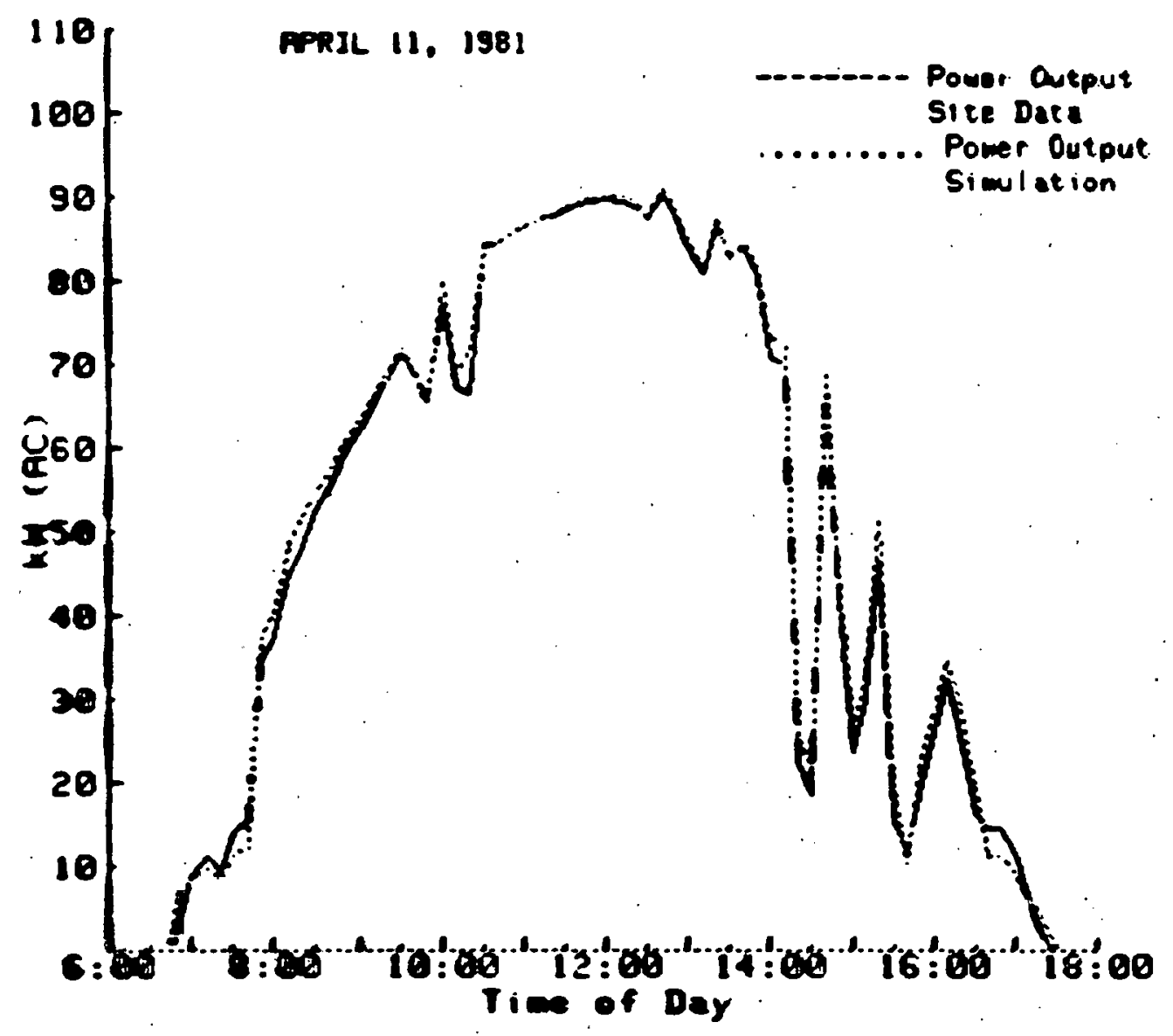

reASURED SYSTER PERFOPRANICE

vs

COMPUTER SIMULATION RESULTS 
SUMMARY OF SYSTEM PERFORMANCE

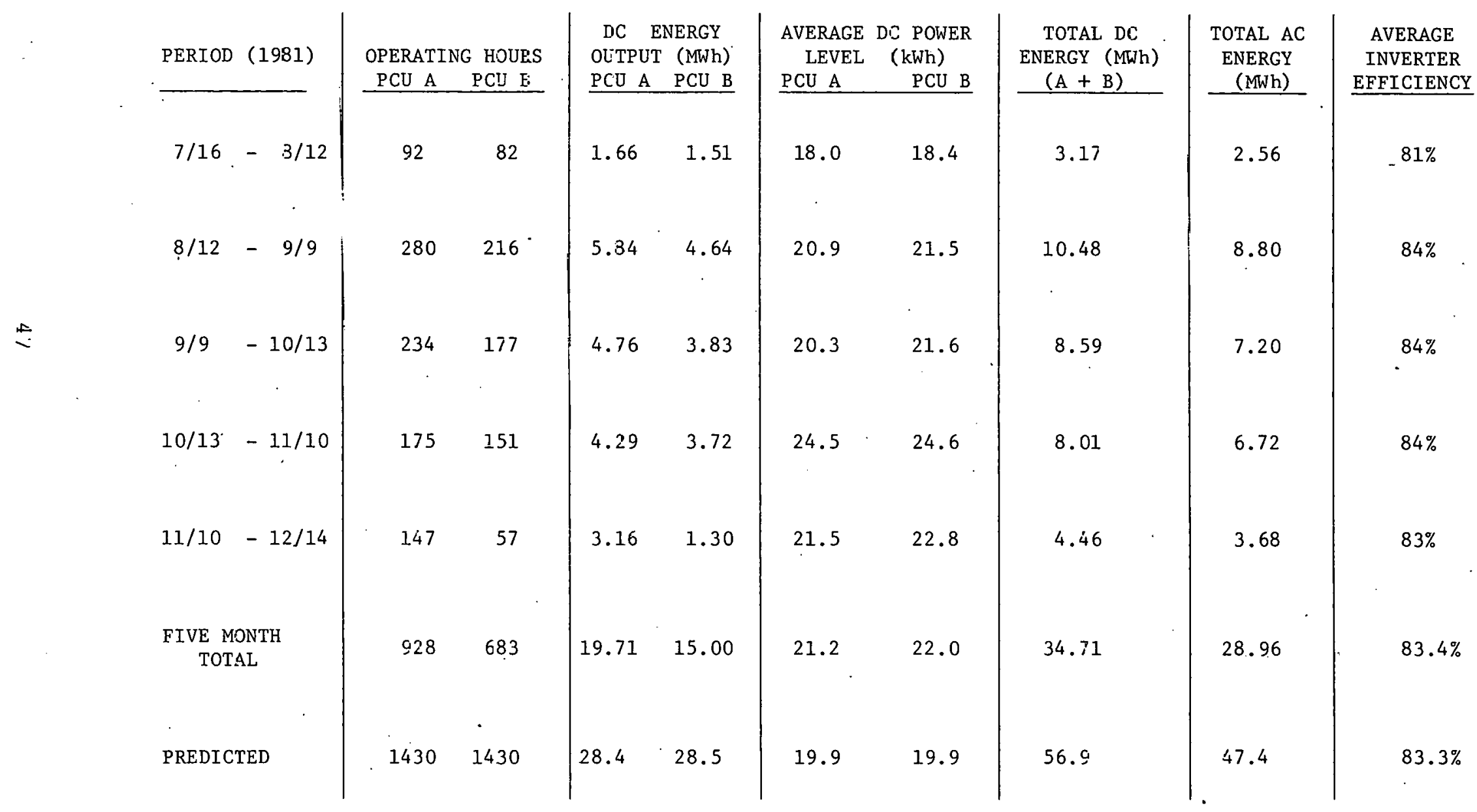




\section{MAIN PROBLEMS TO DATE}

I. LOSS OF OPERATING HOURS DUE TO GROUND FAULT TRIPOUTS OF INVERTERS

- REQUIRES MANUAL RESET

- DOWN TIME UNKNOWN (MAY VARY FROM HOURS TO DAYS BEFORE NOTICED BY SITE PERSONNEL)

- NOT CAUSED BY TRUE GROUND LEAKAGE

- SPURIOUS CURRENT PULSES OF UNKNOWN ORIGIN

II. LOSS OF COMPUTER DATA ACQUISITION DUE TO COMPUTER ERROR SHUTDOWNS

- REQUIRES MANUAL RESTART

- DOWN TIME UNKNOWN (MAY VARY FROM HOURS TO DAYS BEFORE NOT ICED BY SITE PERSONNEL)

- CAUSE UNKNNOWN (HARDWARE? SOFTWARE? BOTH?)

- DRAMATIC IMPROVEMENT FOLLOWING HARDWARE CHECKOUT AND INSTALLATION OF NEW SOFTWARE PACKAGE 


\section{OTHER PROBLEMS}

I. CIRCUIT FAULT DEVELOPED IN ONE INVERTER

- ONE INVERTER DOWN MOST OF TWO MONTHS

- NO SPARE PARTS ON HAND

II. ENERGY METERS PULSE INITIATORS TO ODAS COMPUTER

- TOO INFREQUENT ON SYSTEM OUTPUT AND INVERTER HOUSE LOAD METERS (32 $\mathrm{kWh} / \mathrm{PULSE})$

- OK ON UTILITY INTERFACE METERS $(0.96 \mathrm{kWh} /$ PULSE $)$

III. SUN TRACKER ON NIP NOT OPERATIONAL. .

- HARDWARE REPAIRED

- SOFTWARE PROBLEM SUSPECTED (FIRST TRY REJECTED BY COMPUTER)

IV. EXCESSIVE EROSION ON ROADS BETWEEN SUBARRAYS

- DEEP GULLIES FORMED

- WASHED OUT MATERIAL FILLING CATCH BASINS

- REPAIRS AUTHORIZED (BUT NOT EFFECTED BEFORE SNOW) 
DR. YUDI P. GUPTA

SCIENCE APPLICATIONS, INC.

1710 GOODRIDGE DRIVE

MCLEAN, VIRGINIA 22102

The OCSA PV system is a demonstration project for an intermediate size utility connected system serving an institutional or commercial load center. The major objectives, common to all such systems, are to verify the technical feasibility and acceptability of a utility parralled PV power source for similar faciljties and to acquire experience which will lead to the economic viability of load center PV systems in general. It is fixed, flat plate, roof-molinted array interfaced to the facility $480 \mathrm{~V}$ AC bus through a Windworks inverter.

A number of unique features are-incorporated in the system. They include polycrystalline solar cells, reflcctor augmentation which aids in matching the power output to the annual load profits, and a.module design which maintains high efficlency under non-uniform illumination and which minimizes the effect of included all failures.

The electrical design of the module was accomplished by SAI in 1979. It has features which are now recognized as essential for reliable power systems. Many of these features are evident in the new BLOCK $V$ specifications. The module has no frame, eliminating duplication of module and supporting structure costs. The 12 series by 6 parrallel cell configuration includes $100 \%$ parallel connections to enhance reliability. Integral pigtails and polarized connectors eliminate all branch circuit field wiring except for connection of branch circuit ends to the junction boxes.

System installation was completed in January and it is now undergoing test and checkout. It appears that all objectives will be met.

The power conditioning unit is interfaced to the AC bus thru a transformer. This has two advantages: the array voltage is always less than $600 \mathrm{~V}$ even under open circuit conditions allowing the use of low voltage wiring, and any DC components are completely isolated froin the $A C$ line.

The supporting structures are steel, prefabricated into assemblies that hold eight modules and eight reflectors. The base coiumn has a telescoping feature which permitted precise alignment of the array without regard to irregularities in the roof plane. The telescoping sections were welded in place after alignment. The structure design offers economy in both fabrication and installation. 


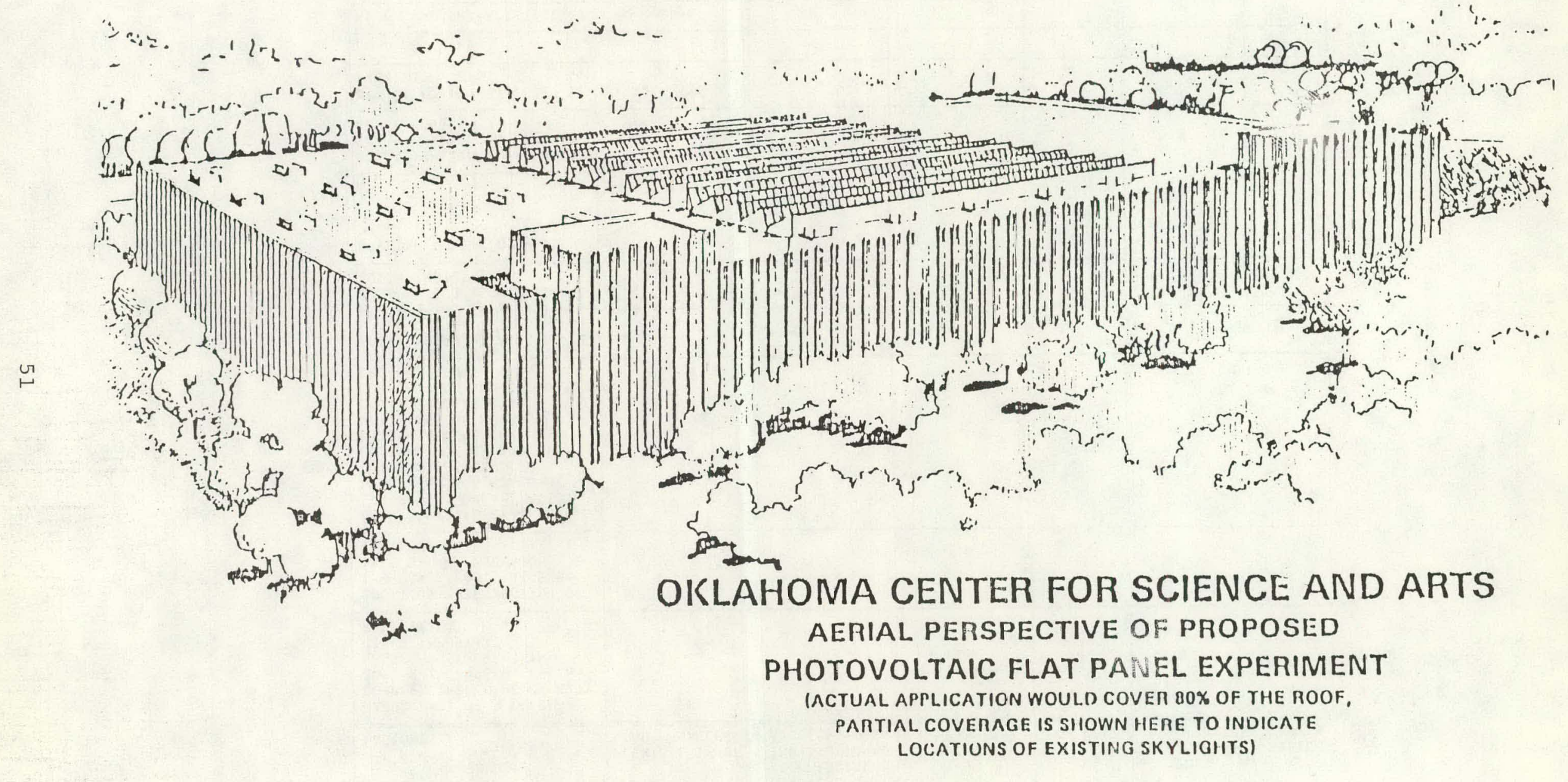




\section{SOME FEATURES OF OCSA EXPERIMENT SITE}

\begin{tabular}{|c|c|c|c|c|c|c|}
\hline FACTORS & $\begin{array}{l}\text { FLEXIBILITY OF } \\
\text { LOAD MANAGEMENT } \\
\end{array}$ & $\begin{array}{l}\text { TYPICAL OF } \\
\text { COMMERCIAL/ } \\
\text { INSTITUTIONAL } \\
\text { APPLI I CATIONS } \\
\end{array}$ & $\begin{array}{r}\text { HIGH } \\
\text { VISIBILITY } \\
\end{array}$ & LOW COST & \begin{tabular}{l}
\multicolumn{1}{c|}{ POST } \\
EXPERIMENT \\
UTILIZATION \\
\end{tabular} & $\begin{array}{l}\text { SYSTEM } \\
\text { GROWTH } \\
\end{array}$ \\
\hline $\begin{array}{l}\text { MAJOR PART OF A CULTURAL } \\
\text { COMPLEX INCLUDING OK CITY } \\
\text { ZOO, RAIN FOREST, GREEN- } \\
\text { HOUSE, RESTAURANT AND } \\
\text { OTHER IMPORTANT } \\
\text { FACILITIES }\end{array}$ & $x$ & & $\begin{array}{c}x \\
>\operatorname{lM} V 1 S I T O R S \\
\text { IN } 1980\end{array}$ & & 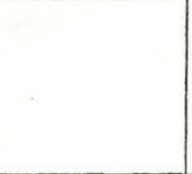 & $x$ \\
\hline $\begin{array}{l}\text { LOCATION INTERSECTION OF } \\
\text { I- } 35 \text { AND } 1-40 \text {, ACCESS- } \\
\text { IBLE BY ALL MODES OF } \\
\text { TRANSPORTATION }\end{array}$ & & & - & & & \\
\hline $\begin{array}{l}\text { OCSA-OPERATED BY A PUBLIC, } \\
\text { NON-PROFIT ORGANIZATION } \\
\text { DIRECTED BY A BOARD OF } \\
\text { GOVERNORS INCLUDING } \\
\text { GORERNOR OF OK AND DIS- } \\
\text { TINGUISHED SENIOR } \\
\text { OFFICIALS OF REGIONAL, } \\
\text { CIVIC, EDUCAT IONAL, } \\
\text { COMMERCIAL, AND CULTURAL } \\
\text { ORGANIZATIONS }\end{array}$ & - & & $x$ & & $x$ & $x$ \\
\hline $\begin{array}{l}\text { PROVIDES ADJUSTABLE AC/DC } \\
\text { LOADS }\end{array}$ & $x$ & & & & & \\
\hline $\begin{array}{l}\text { OCSA ROOF DESIGNED FOR } \\
\text { SOLAR FACILITY }\end{array}$ & & & & $x$ & & \\
\hline SPECIAL PUBLIC DISPLAY & & & $\mathrm{x}$ & $\begin{array}{c}X \\
\text { NO COST } \\
\text { TO } \\
\text { PROUECT }\end{array}$ & $x$ & $\mathrm{x}$ \\
\hline $\begin{array}{l}\text { OPERATION EVERY DAY OF THE } \\
\text { YEAR--MAXIMAL ON-SITE USE } \\
\text { OF PY POWER }\end{array}$ & $x$ & & & & $x$ & \\
\hline $\begin{array}{l}\text { ACTIVE UTILITY INTER- } \\
\text { FACE WITII OGSE }\end{array}$ & $x$ & $x$ & $x$ & $x$ & $x$ & $x$ \\
\hline LOAD MATCHING & $x$ & $x$ & & $x$ & & \\
\hline SITE LOAD CHARACTERISTICS & $\mathrm{x}$ & $x$ & & & & $x$ \\
\hline POLYCRYSTALLINE SI CELLS & & & & $x$ & & \\
\hline POST EXPERIMENT POTENTIAL & $\begin{array}{l}\text { ACT AS A POWER } \\
\text { SOURCE FOR OCSA }\end{array}$ & & $\begin{array}{l}\text { CONTINUE AS } \\
\text { EXHIBIT AND } \\
\text { DISPLAY }\end{array}$ & & $\begin{array}{l}\text { 08M } \\
\text { EXPERIENCE } \\
\text { AND DATA }\end{array}$ & $\begin{array}{l}\quad X \\
\text { IF } \\
\text { PROVEN } \\
\text { ECONOM- } \\
\text { ICALLY } \\
\text { FEASIBLE }\end{array}$ \\
\hline
\end{tabular}




\section{SYSTEM DESIGN CRITERIA}

\begin{tabular}{|c|c|c|}
\hline SITE DEPENDENT CRITERIA & SYSTEM CONSTRAINTS & EXPERIMENTT RELATED CRITERIA \\
\hline 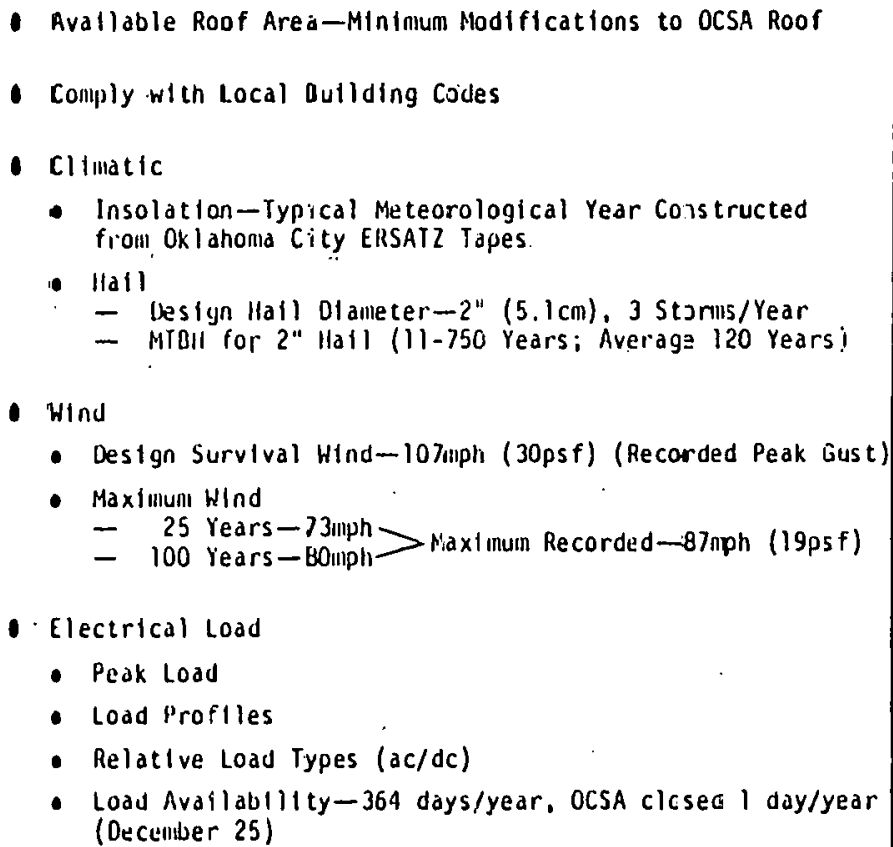 & 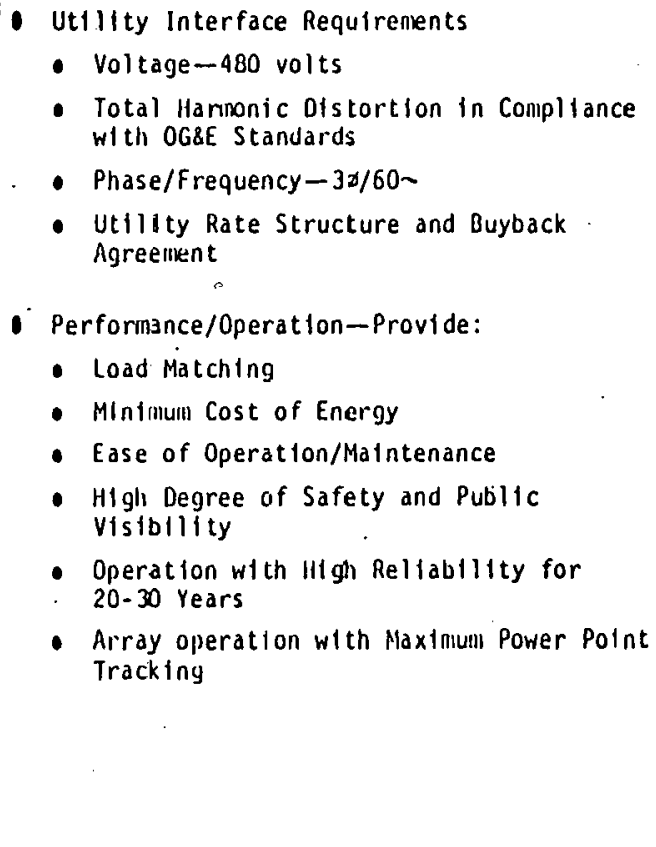 & $\begin{array}{l}\text { - Inccrporate Independent Data } \\
\text { Acquistition. Control. and Sensing } \\
\text { Capcbility for: } \\
\text { - Evaluation of Technical and } \\
\text { Economic Perfornance } \\
\text { - Monitoring and Analysis of System } \\
\text { Operation/Maintenance } \\
\text { - Monitoring and Evaluation of } \\
\text { sulsysteni Perforilance, Operation. } \\
\text { and Failure Modes } \\
\text { - Experiments in Load Managenient } \\
\text { - Monitoring and Evaluation of } \\
\text { Envilronnental and Non-Technical } \\
\text { Issues }\end{array}$ \\
\hline
\end{tabular}


SYSTEM CONCEPT
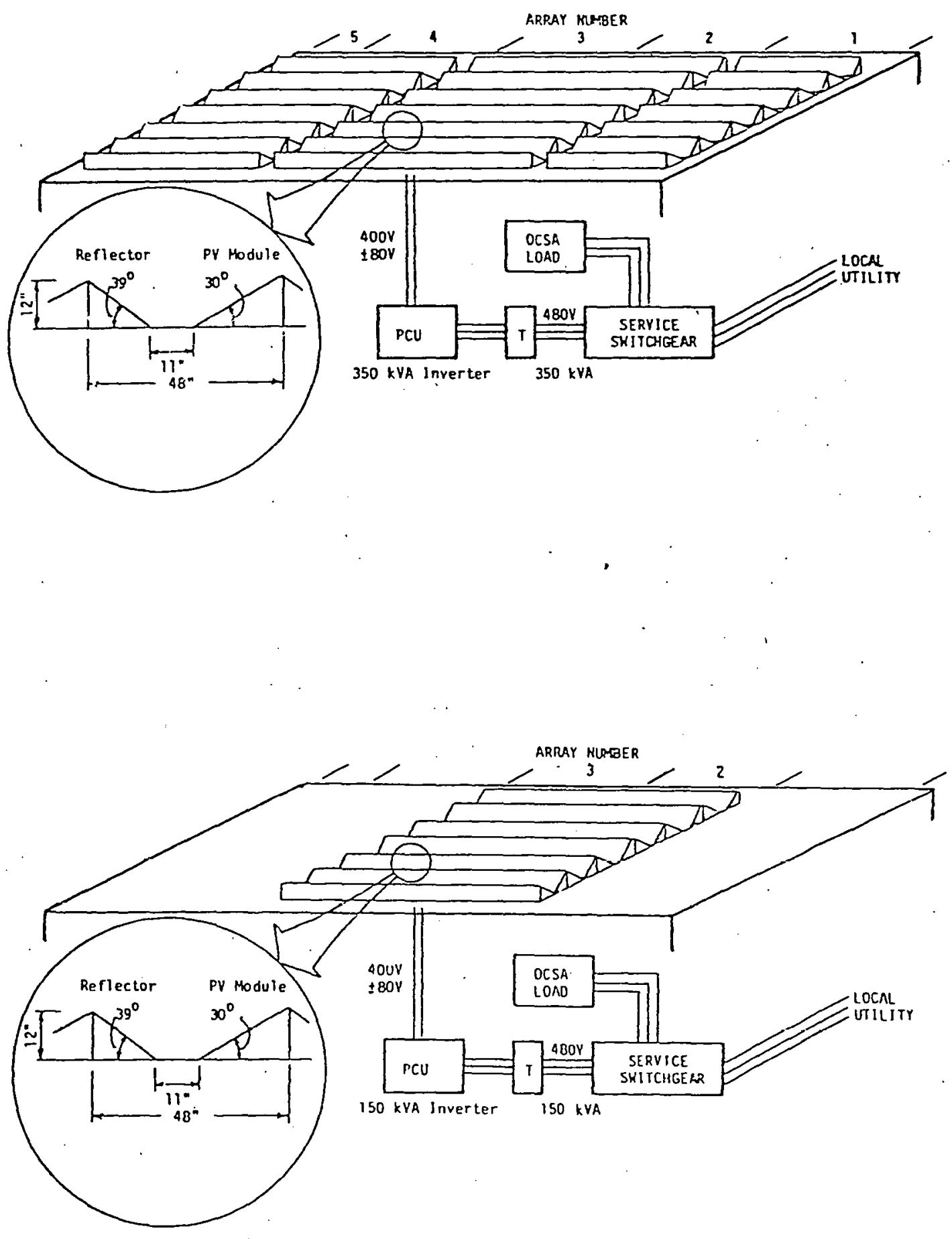
OKLAHIJMA CENTER FOR SCIENCE AND ART TYPICAL DAY LOAD PROFILES

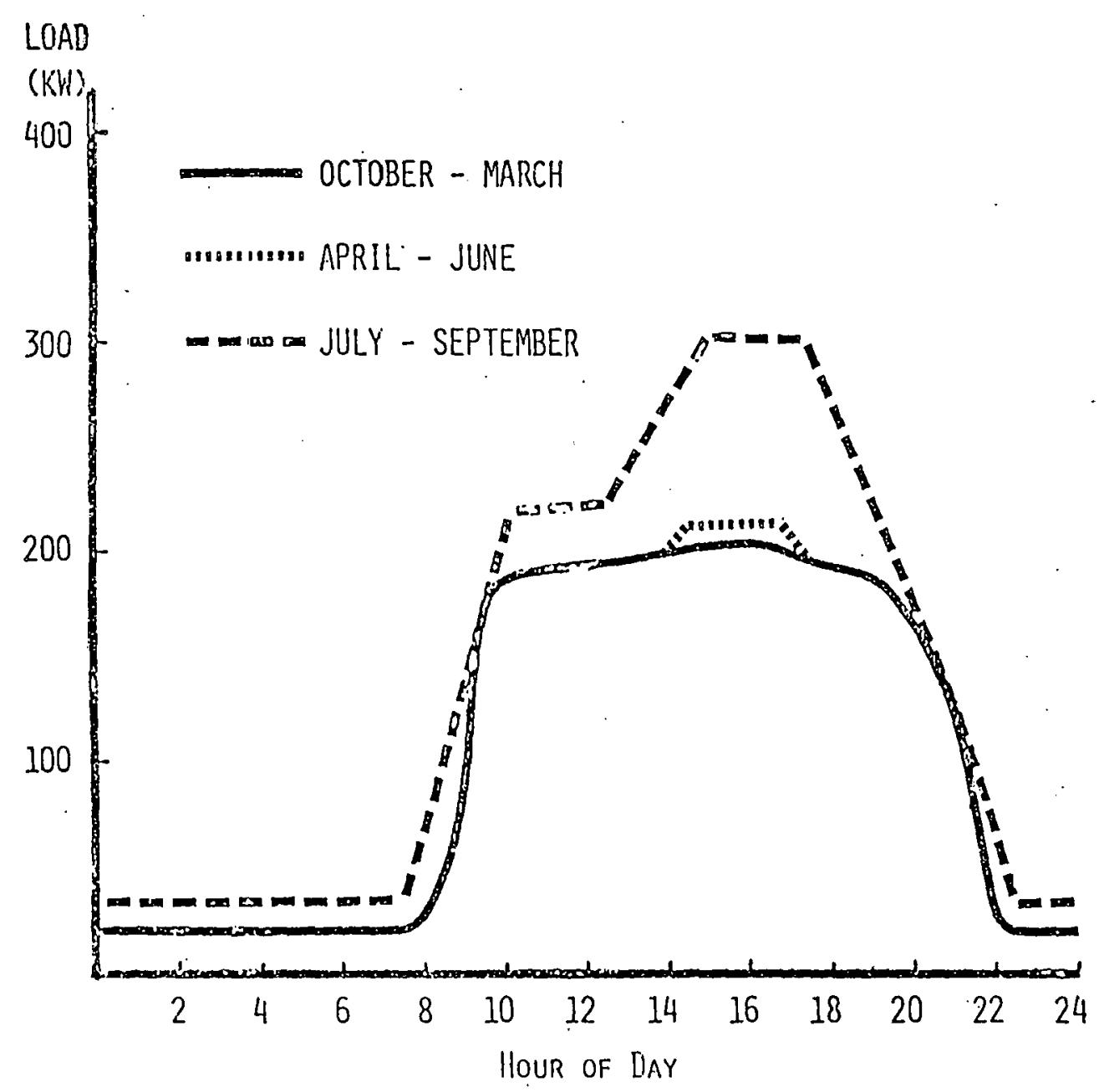




\section{TECHNICAL HIGHLIGHTS}

- SYSTEM hAS LOW PROFILE, EASY' ACCESS FOR 0\&M, SENSORS FOR DATA COLLECTION, AND AN INDEPENDENT PUBLIC DISPLAY

- REFLECTOR AUGMENTION OF MODLLE OIITPUT PROVIDES LOW-COST ENHANCEMENT AND LEVELS OUT THE OUTPIIT PEAK AT NORMAL SLIN ANGLE

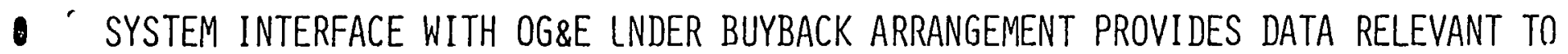
UTILITY ACCEPTANCE OF PV SYSTEMS

- DEVELOPMENT \& TESTING OF $2^{\prime} \times 4^{\prime}$ POLY-Si CELL NODULES WITH $\sim(10 \mathrm{~cm} \times 10 \mathrm{~cm})$ CELLS

- high PaCking DENSITY, high EFFICIENCY MODUI.E WITH LOW VOLTAGE-HIgh CURRENT OPERATION. READY FAUI.T IDENTIFICATION AND SIMPLE. INSTALLATION.

- high MODIILE RELIABILITY dIIE TO MAXIMUM INTERCELL PARALLEL CONNECTIONS

- MODULE RUGGed tO SEVERE ENVIRONMENTAL CONDITIONS

- POLY-SI CELL MODULE OFFERS SIGNIFICANT POTENTIAL FOR COST REDUCTION 
SYSTEM ANALYSIS

ISSUE

Module Series/Parralel INTERCOINECTIONS

Methods to Mitigate Transients
RANGE OF

ALTERNATIVES CONSIDERED

- 72 Cells in series

- 6 Strings of 12 cells each

- 5 Strings of 12 cells with CELL BY CELL PARALLELISM

- Parallelism

- Brpass diodes

- BLocking DIODES

- Module angle $10^{\circ}$ to $55^{\circ}$

- Reflector angle $21^{0}$ to $39^{\circ}$

- Shading angle $21^{0}$ to $31^{\circ}$

\section{PREFERRED ALTERNATIVE}

- 6 Strings of 12 cells with CELL BY CELL PARALLELISM.

- Maximum intramodule PARALLELISM

- Bypass diode integral to MODULE

- Blocking diode at end of STRING

- Module angle $30^{\circ}$

- Reflector angle $39^{\circ}$

c Shading angle $25^{\circ}$

- Array size-3948 modules 
SYSTEM ANALYSIS (CONTINUED)

ISSUE

Power Conditioning

Alternatives

Array Circuit Design

Electrical Energy Storage

Cooling Alternatives

\section{RANGE OF}

ALTERNATIVES CONSIDERED

- Manufacturers:

- WINDWORKS

- Westinghouse

- Garrett

- RANGe LIMIT ON INPUT VOLTAGE $\pm 0 \%$ TO $20 \%$

- String length 54 to 120 MODULES

- No storage to 1000KWH STORAGE

- ONe-Side/TWO-Side NATURAL CONVECTION

- Fins

- Fans

- Fins and Fans

\section{PREFERRED ALTERNATIVE}

- WINDWORKS

- Input voltage range $\pm 20 \%$

- 84 MODULES

- No storage except as EXPERIMENTAL OPTION

- Two-side natural CONVECTION 
MONTILLY ENERGY USAGE AND SYSTEM OUTPUT (150 kW)

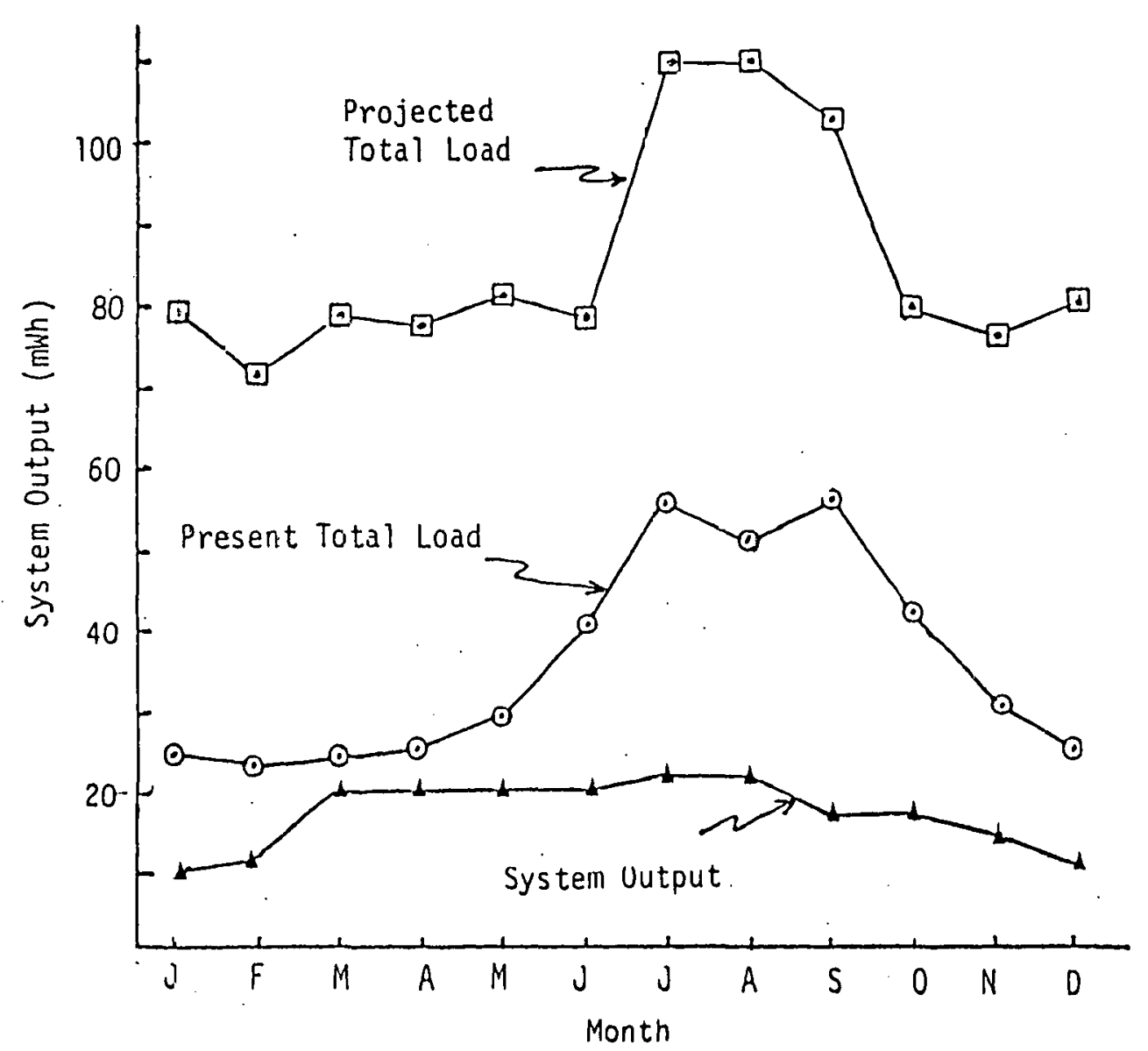


- MAXIMIZE REFLECTOR. BEINEFITS-MAXIMUM PARALLELISM

c MINIMIZE THE EFFECTS OF CELL OR MODULE FAILURE-MAXIMUM PARALLELISM

C MINIMIZE THE REQUIREMENTS FOR PROTECTION DIODES-LOW MODULE VOLTAGE

C REDUCE HARDWARE COSTS-END TO EIND MODULE INTERCONNECTS

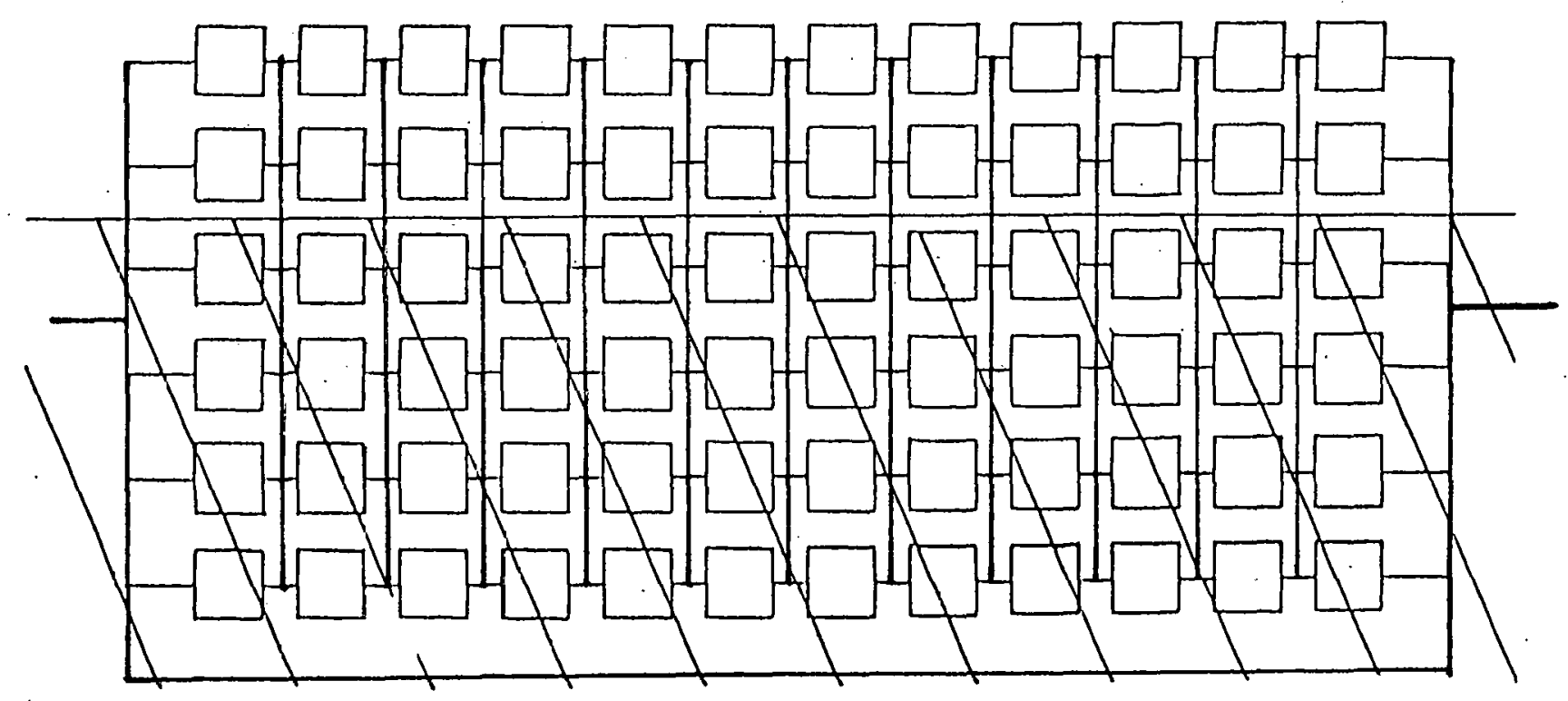




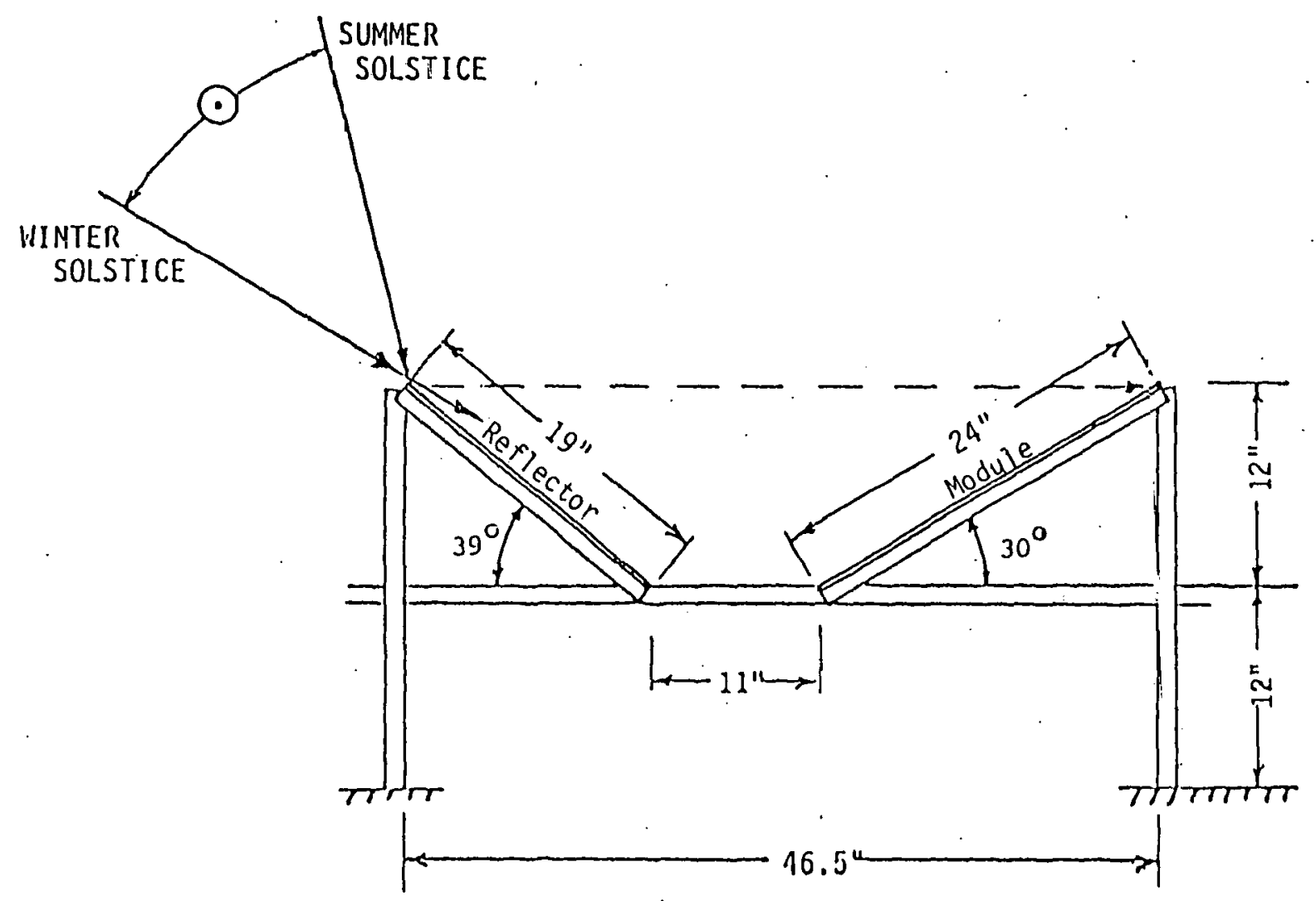




\section{PROJECT TEAM ORGANIZATION AND RESPONSIBILITIES}

DEPARTMENT OF ENERGY

SCIENCE APPLICATIONS, INC,

Prime Contractor

Systems Integrator

Construction Manager

Y. Gupta, Project Manager

\begin{tabular}{|c|c|c|}
\hline OKLNIOMA GAS \& ELECTRIC & $\begin{array}{c}\text { CONSTRUCTION } \\
\text { CONTRACTOR AND } \\
\text { SLBCONTRACTORS, TBS* }\end{array}$ & $\begin{array}{l}\text { SOLAREX } \\
\text { CORPORATION }\end{array}$ \\
\hline $\begin{array}{c}\text { Utillty Interface } \\
\text { Cooperating Organization }\end{array}$ & $\begin{array}{l}\text { Material } \\
\text { Acquisition } \\
\text { Fabrication } \\
\text { Construction } \\
\text { and } \\
\text { Installation }\end{array}$ & $\begin{array}{c}\text { Module } \\
\text { Production } \\
\text { and } \\
\text { Fabrication } \\
\text { W. Lindmayer }\end{array}$ \\
\hline
\end{tabular}

*TBS--to be selected by Competitive oldding 


\title{
DESIGN, CONSTRUCTION AND OPERATION OF A CONCENTRATING PHOTOVOLTAIC TOTAL ENERGY SYSTEM IN HAWAII
}

\author{
By \\ Acurex Corporation \\ 485 Clyde Avenue \\ Mountain View, California 94042 \\ Principal Investigator: Bob Spencer \\ (415) 964-3200 Ext. 3534 \\ Project Manager: Dariush Rafinejad \\ (415) 964-3200 Ext. 3532 \\ Contract Number: DE-AC04-79ET20623 \\ Contract Amount: $\$ 2,234,677$ \\ Contract Duration: 2 years construction, \\ 2 years operation
}

\section{Project Description}

The project is intended to evaluate state-of-the-art system components in an integrated system under actual operating conditions. Photovoltaic concentrator prototype hardware had been developed under a DOE/Sandia contract by a variety of contractors, but no system evaluation had yet been performed. The integration of system components at sufficient scale to allow observation of dynamic interaction is a critical step towards understanding photovoltaic-generated energy. The primary benefit of the entire project will be the long-term operational data generated throughout its early lifetime.

The collector subsystem components are an established design and have been produced for a long time. The photovoltaic receiver for the collector was developed through the design stage, then prototyped and tested in order to gain an extra iteration in the design before system construction. After the successful completion of prototype hardware testing, fabrication of system components began. When long lead items were well into procurement, and all other procurement efforts were underway, we were able to start construction onsite in February 1981. Construction was completed in September 1981.

After the startup in September 1981, two major problem areas were encountered. The first was degradation of the cell modules on the photovoltaic receivers, which we had not experienced in thousands of hours of prototype testing. The PVB material which bonds the cells to their glass superstrate was bubbling. The problem turned out to involve overheating of the PVB caused by a manufacturing quality control problem which we experienced at Acurex. This problem was serious but fairly easy to fix. Repairs were started as soon as the problem was uncovered and are now complete. In the field of 1,458 modules, 32 were damaged enough to replace.

The second problem area was the apparent inability of the PCU to function in the actual field environment. Westinghouse personnel arrived onsite with in 2 days of reporting the problem and made every attempt to get the unit to function. During the period of system shutdown, they were able to make modifications to the unit which allowed it to operate. These changes were effected in a fairly short period, and with in 6 weeks of the original scheduled startup, the system was able to come online and operate within specification.

The system operates whenever the weather permits, producing both electricity and hot water for G.N. Wilcox Memorial Hospital in Lihue, Kauai, Hawaii. Acurex will operate the system for the next 2 years to gather operational data to provide valuable insight into design and construction of future solar electric generation systems. 
CONCEVTRATING PHOTOVOLTAIC PO'NER SYSTEM FT G.N NILCOX MEMOR:AL HOSP ITAL

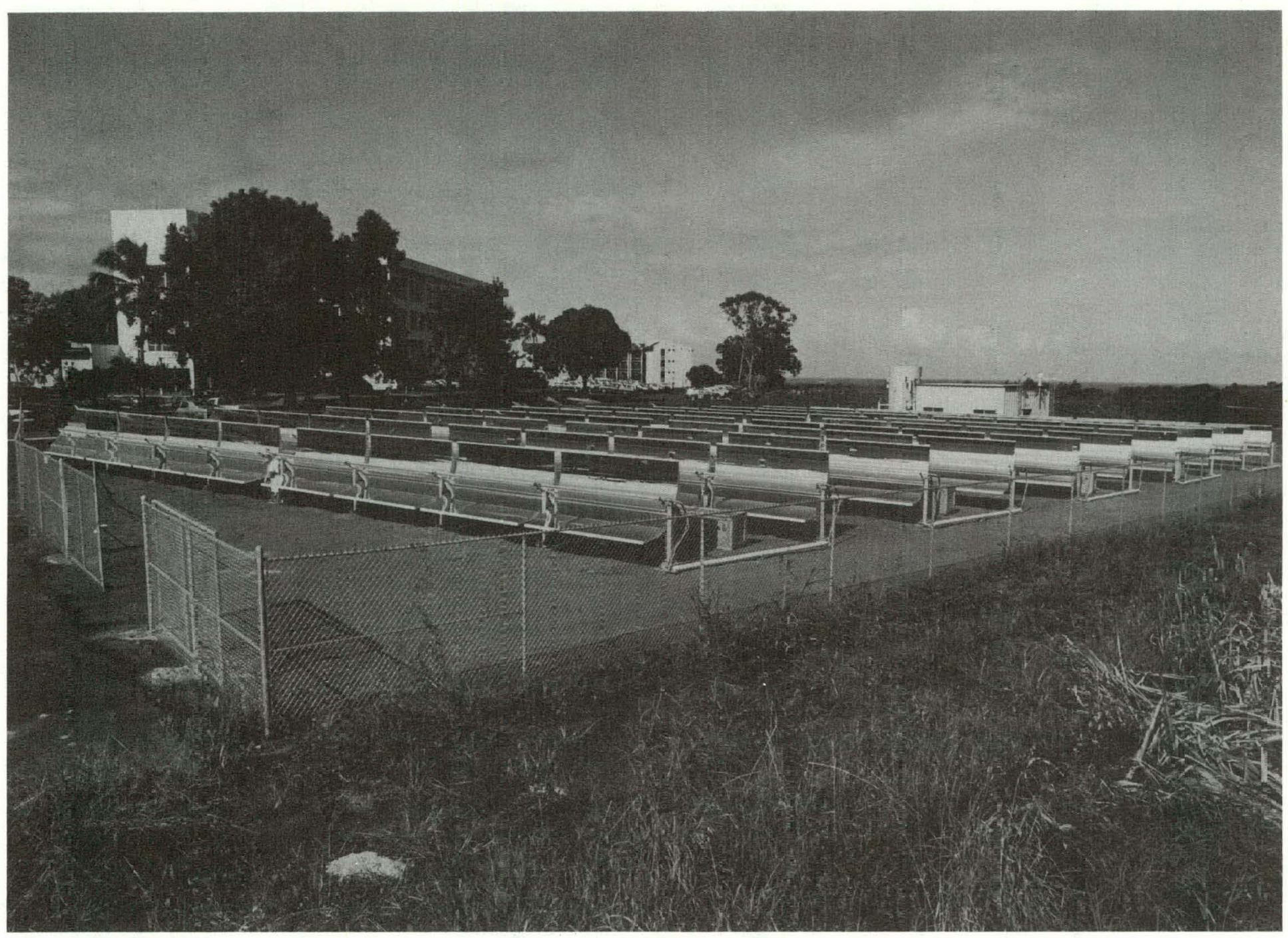


PHOTOVOLTAIC RECEIVER CROSS SECTION

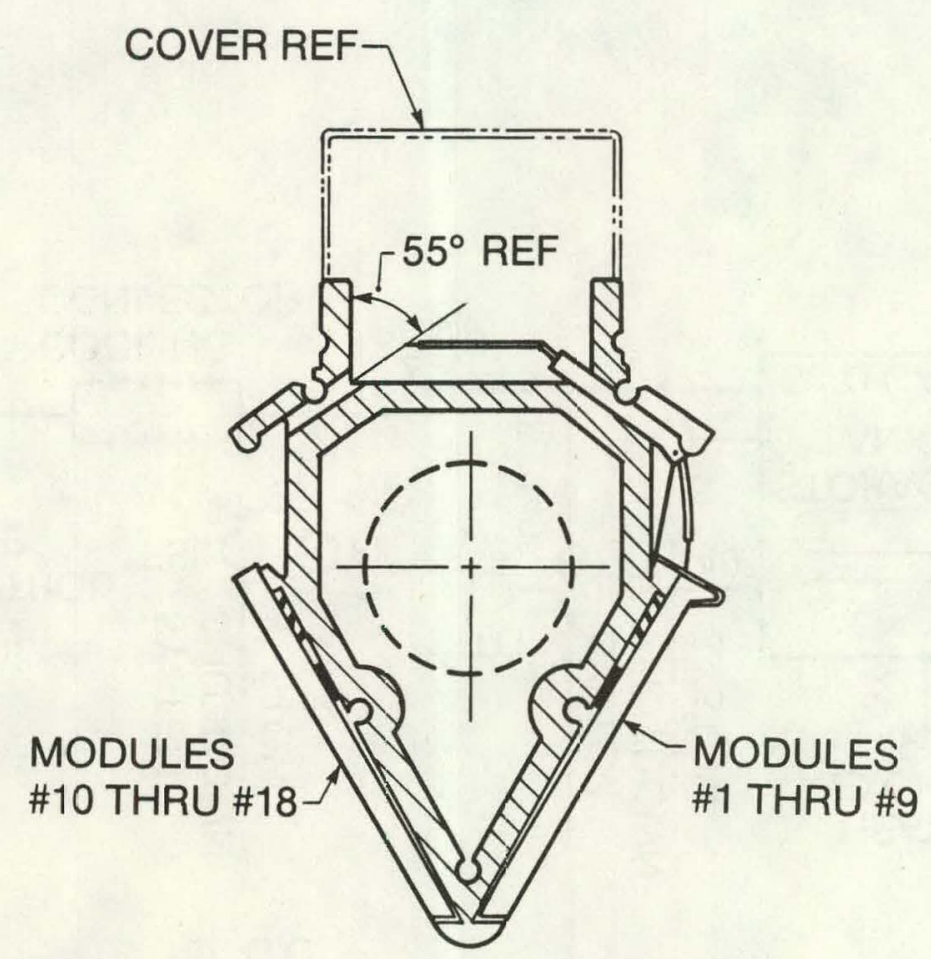


THERMAL SUBSYSTEM

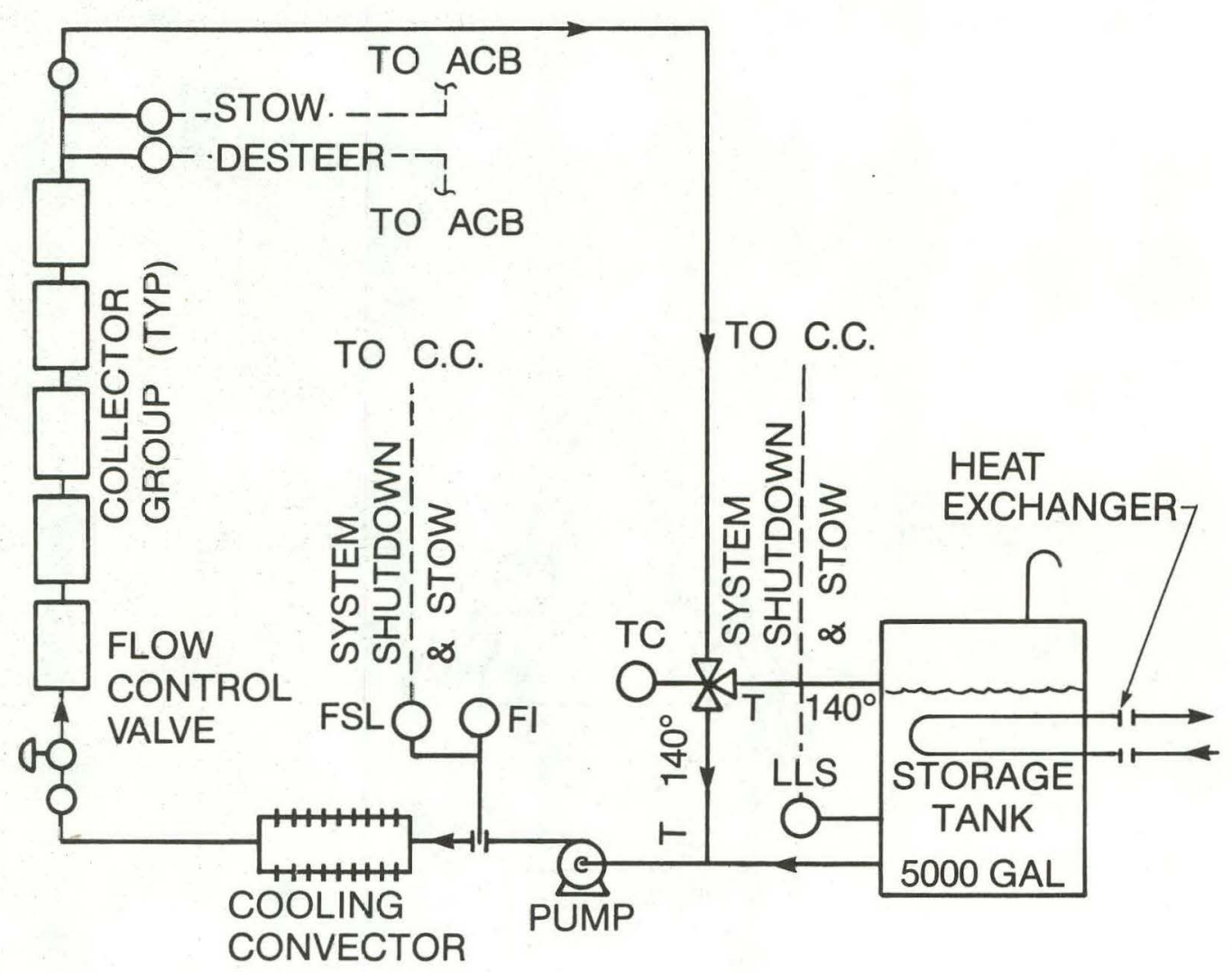


FOUNDATION INSTALLATION

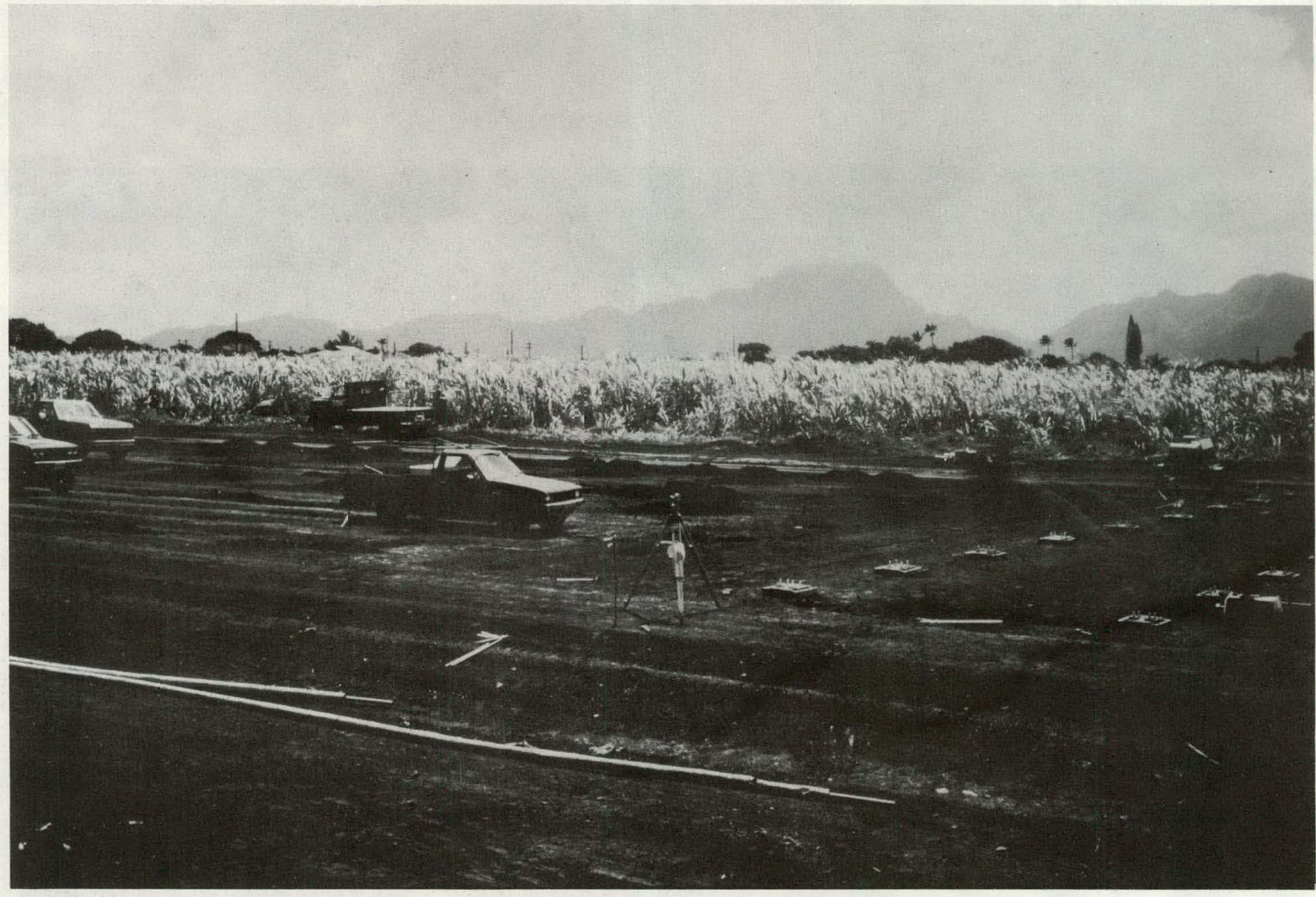


CONCEN'RATOR SHI PF ING ARRANGEYENT

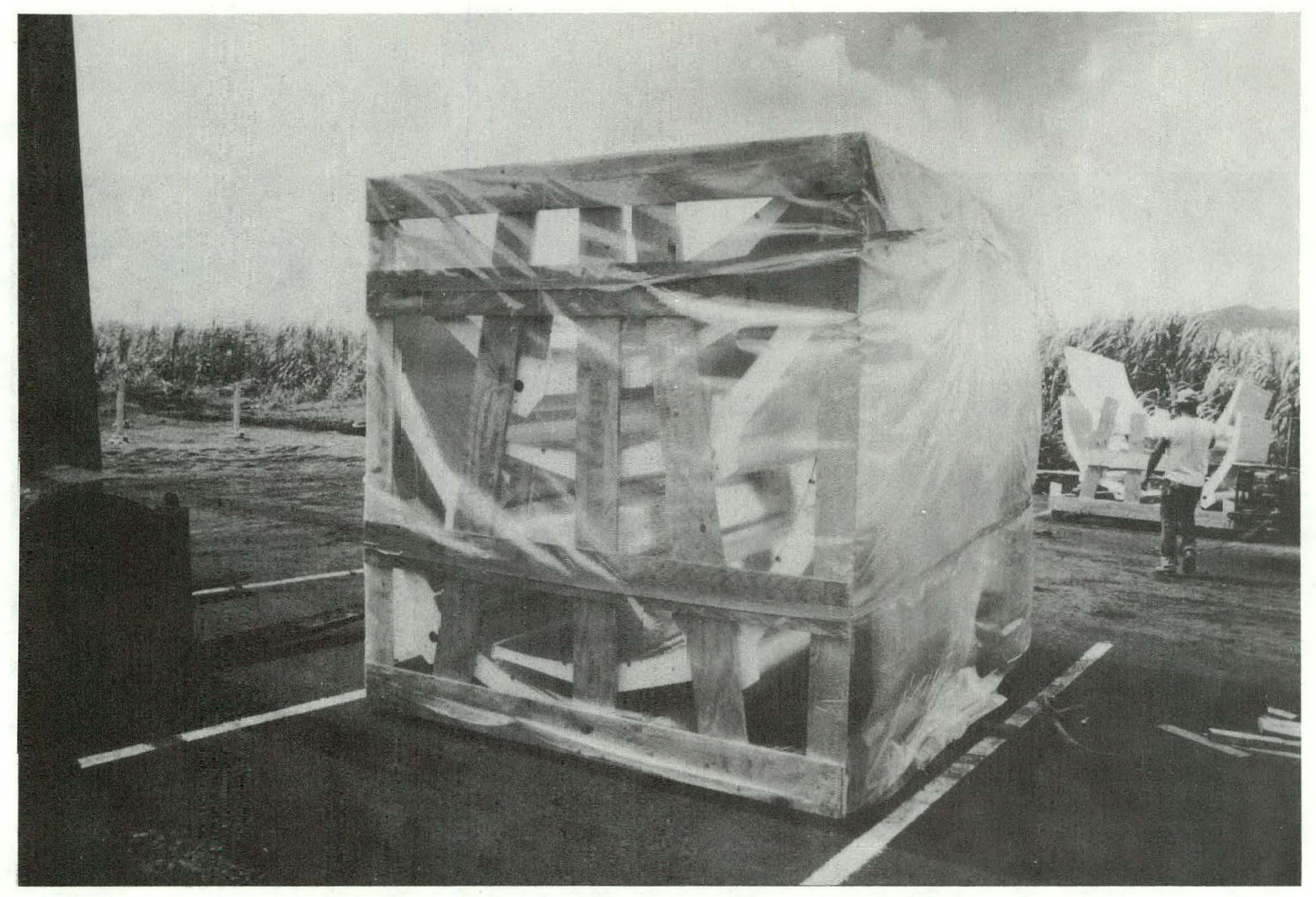


SUPPORT POST INSTA__ATION

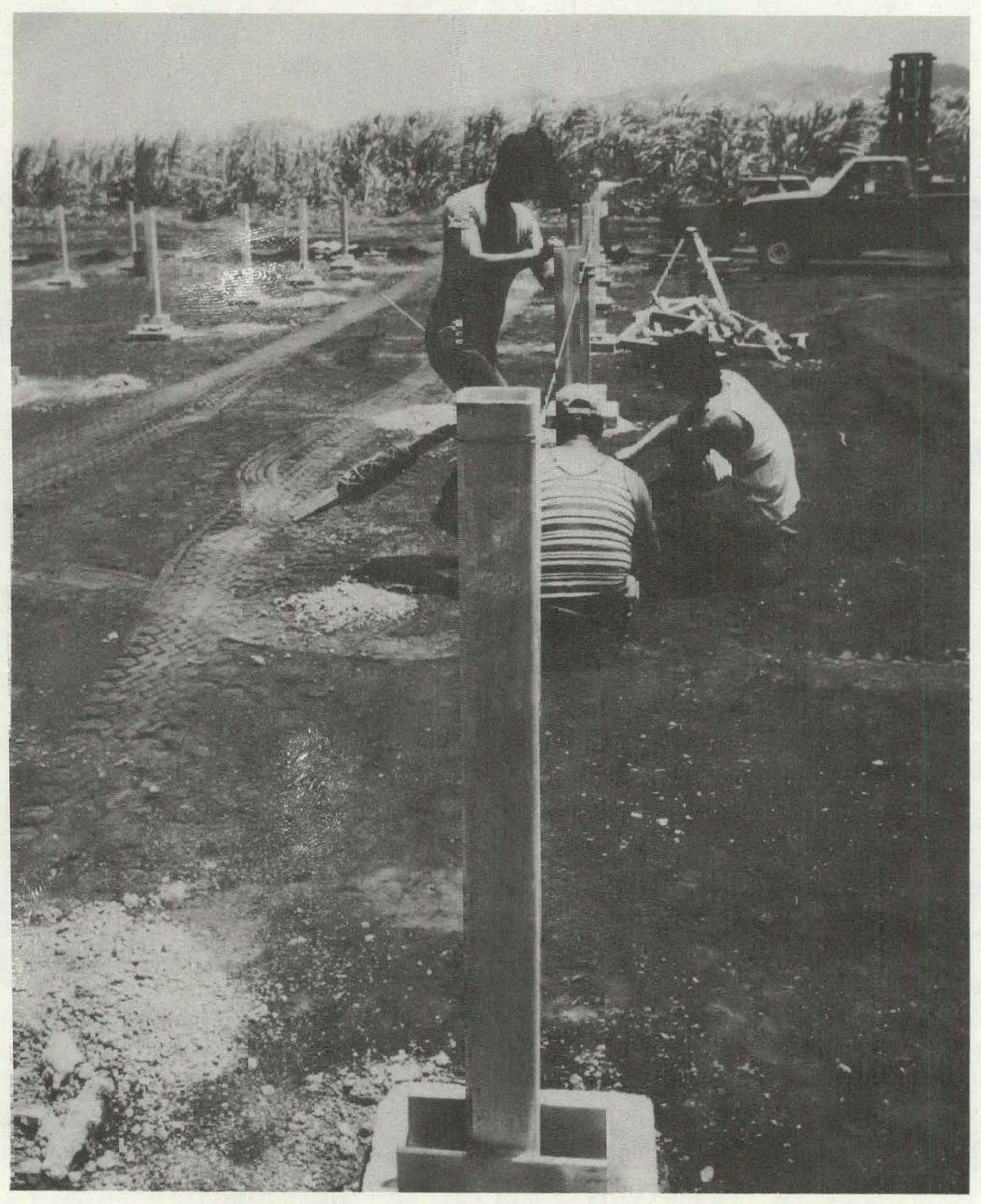


CONCENTRATING COLLECTOR INSTALLATION

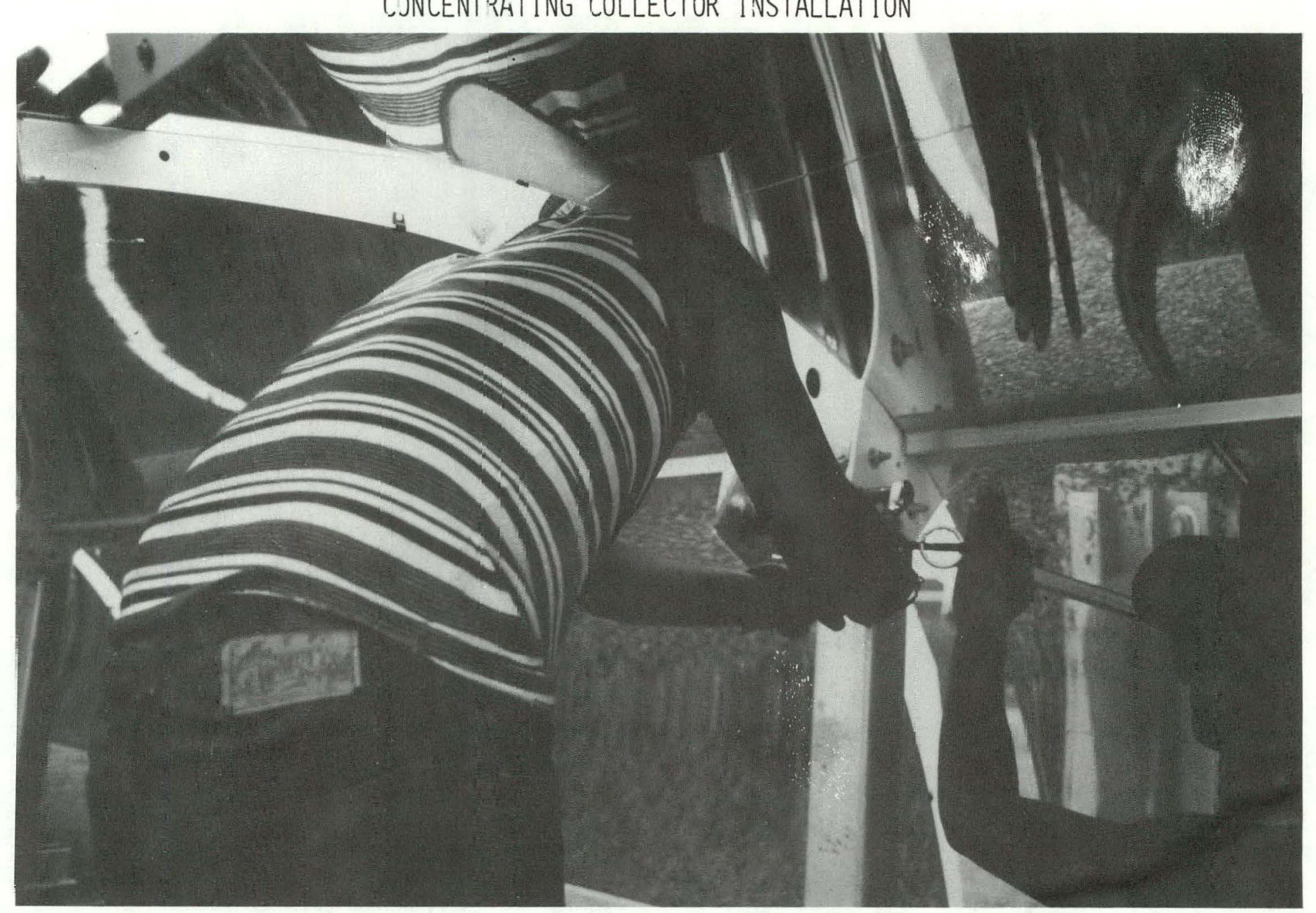




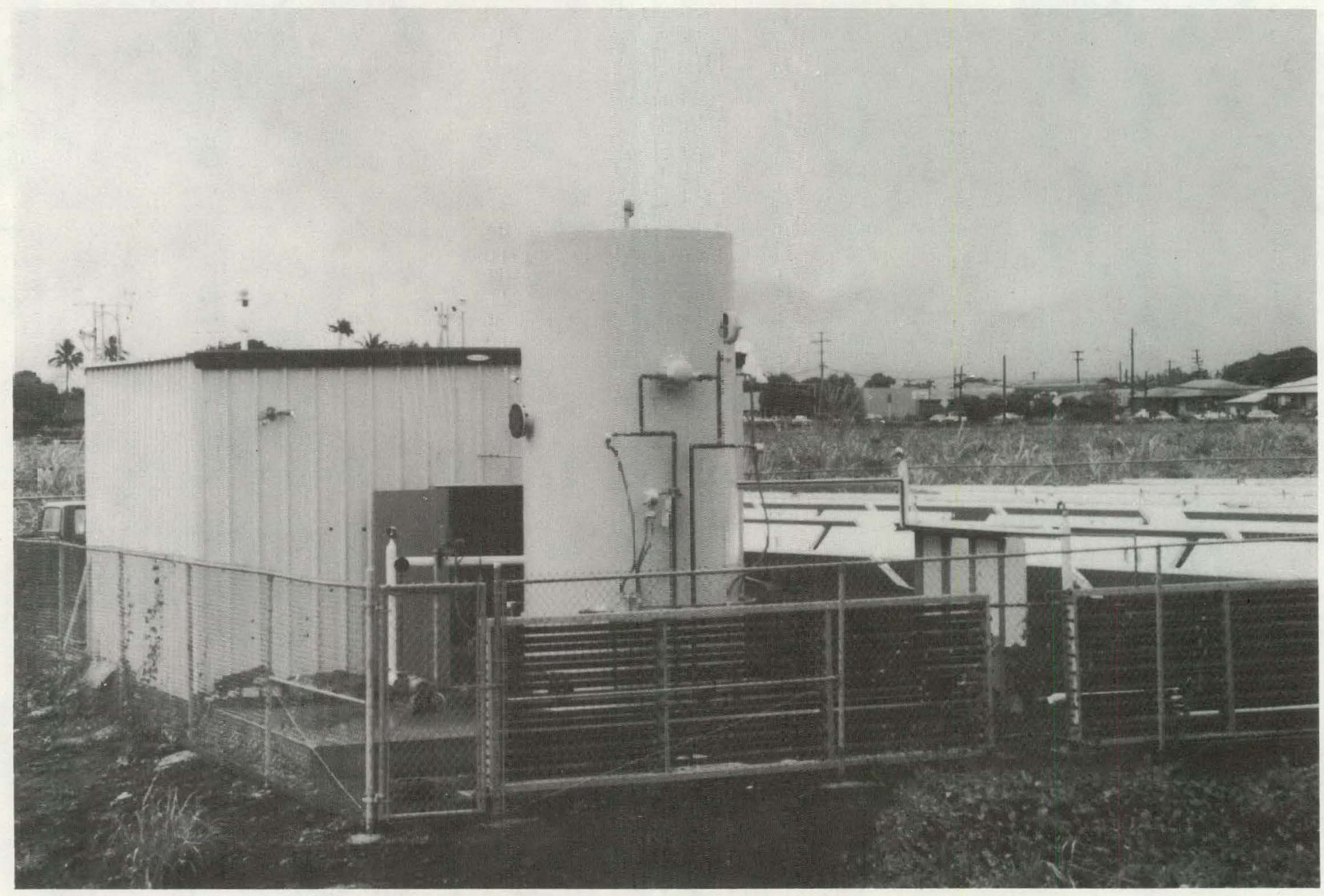


CONTROL CABINET AND PCU
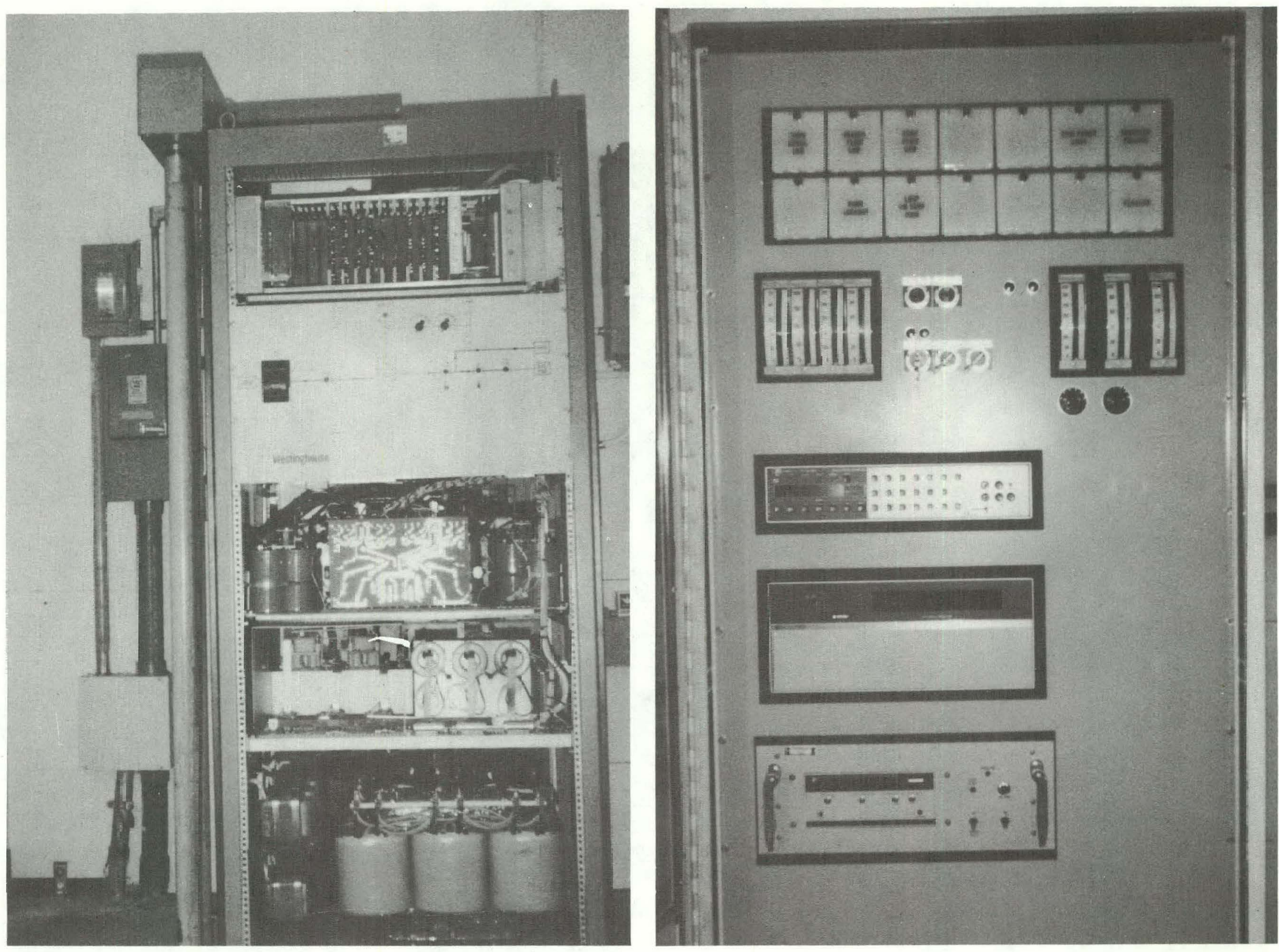
RECEIVER AND FLUID _JOP CONNECTION

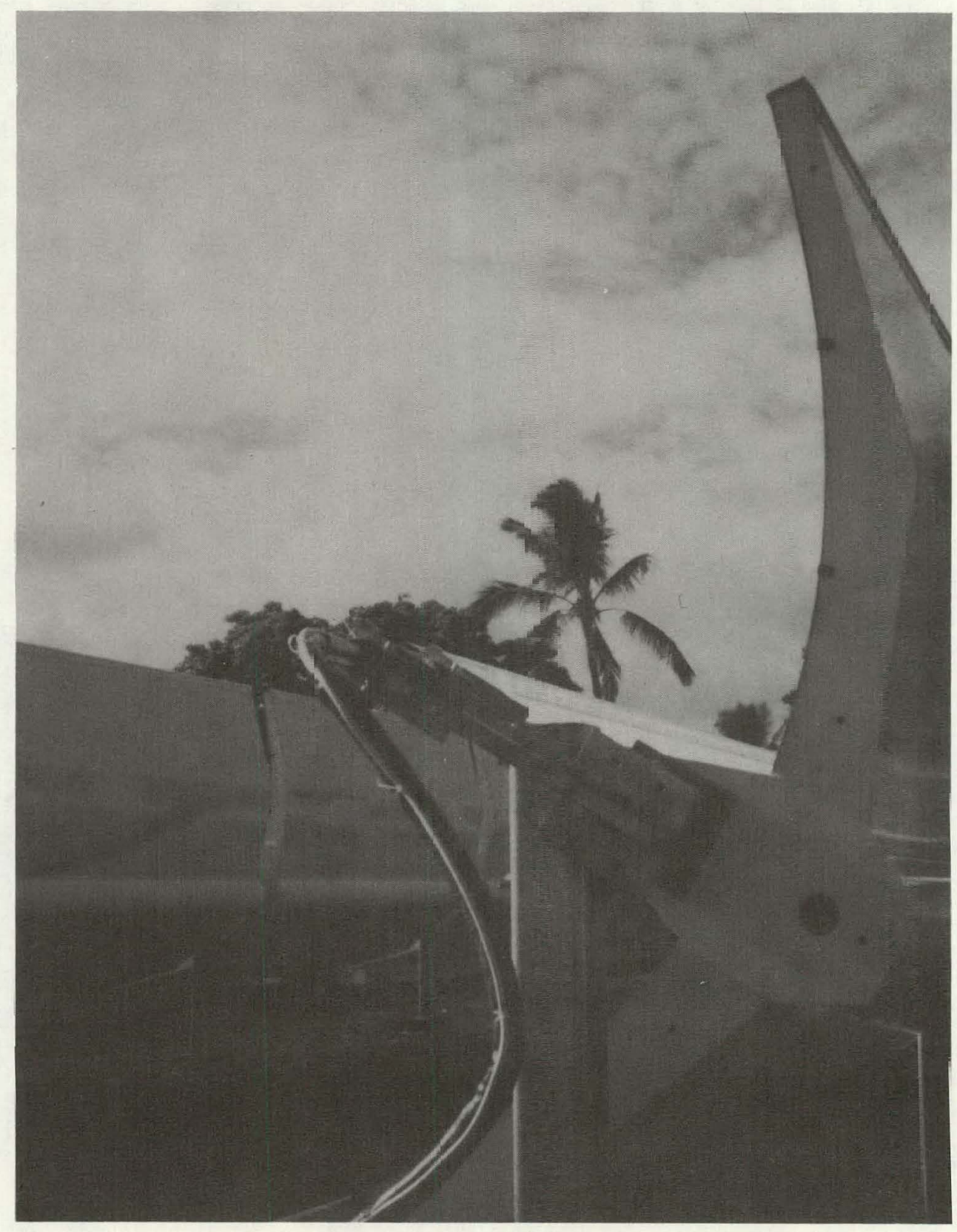


Commercial Application of a Photovoltaic Concentrator System (CAPVC)

\author{
W. R. Kauffman \\ The BDM Corporation \\ 1801 Randolph Road, S.E. \\ Albuquerque, New Mexico 87106
}

The BDM Corporation is nearing the completion of the installation of its photovoltaic concentrator application experiment denoted as CAPVC (Commercial Application of a Photovoltaic Concentrator). This is a nominal 50 kilowatt peak system located on the roof of the BDM facilities in Albuquerque, New Mexico. The photovoltaic concentrating array is a single-axis linear parabolic trough utilizing single crystalline silicon photovoltaic cells under 41.56 suns of net solar concentration. A total of 7,560 square feet of aperture is provided by 54 Solar Kinetics T-700 7-foot aperture mirrors configured in nine north-south oriented rows. A two-piece $90^{\circ} \mathrm{V}$-shape receiver places the cells at the focal point of the mirror and provides cooling utilizing an ethelyne glycol/water mixture. The photovoltaic array is designed to operated in parallel with the local utility in an augmentary load sharing mode. A portion of the thermal energy resulting from the cell cooling is used for building heating during winter months.

The major subsystems of CAPVC are the photovoltaic array, DC and AC power conditioning, thermal system, and the control and data acquisition systems. The array is composed of the concentrating mirror, receiver tube and the PV-cell and module. The power conditioning includes the Westinghouse inverter and the wiring and switchgear. The thermal system involves both a heat rejection circuit and a building heating circuit utilizing ground coupled heat pumps. Components of the control and data acquisition system are the control loops and the instrumentation transducers. The overall control and safety monitoring of the system is accomplished automatically by an AIM-65 micro-computer. The controls and instrumentation equipment are located in a central monitoring area located near the building entrance for easy visitor access. The basis of the data acquisition system is a government furnished HP-9845 computer driven acquisition system.

The system is currently undergoing the final phases of installation. The structural, thermal, electrical and control support hardware has been installed. Work is progressing on the control software for the AIM 65. The single-axis tracking mirror portion of the array has been completed and fabrication of the photovoltaic modules is expected to be finished in late March of 1982. Partial operation of the array began in the month of December 1981 and will be continued through completion of the system installation. 
COMMERCIAL APPLICATION OF A PHOTOVOLTAIC CONCENTRATOR SYSTEM (CAPVC)

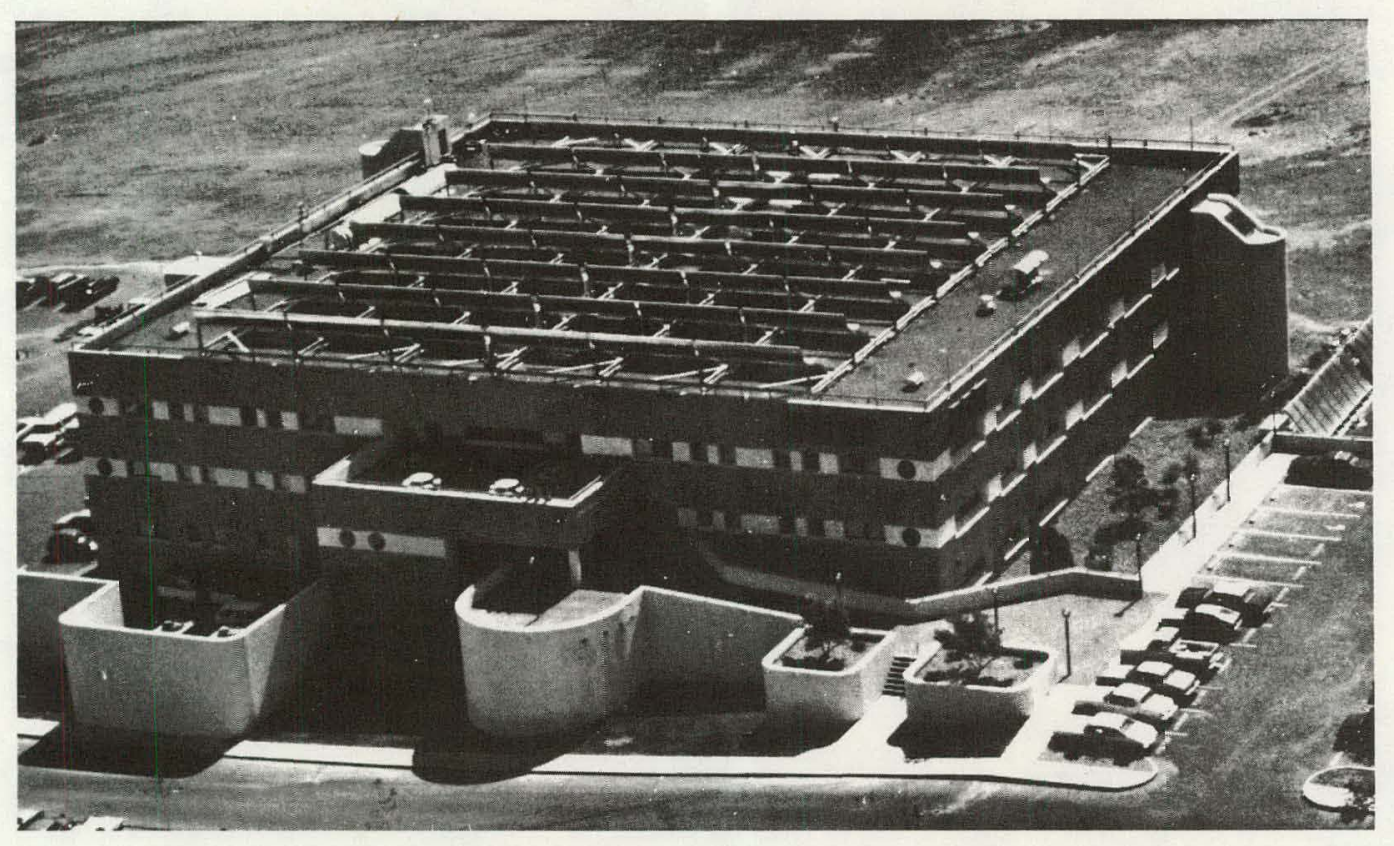




\section{CAPVC DESCRIPTION}

- CONFIGURATION

- ORIENTATION = N/S

- TOTAL APERTURE AREA $=7560 \mathrm{FT}^{2}$

- COLLECTOR NET CONCENTRATION RATIO $=41.56$

- ELECTRICAL ENERGY

- PEAK OUTPUT POWER $=47 \mathrm{~kW}$

- OPERATING VOLTAGE $=230 \mathrm{VDC}$

- OPERATING CURRENT $=205$ AMPS

- thermal ENERGy

- AVAILABLE THERMAL ENERGY $=8 \times 10^{6} \mathrm{BTU} / \mathrm{DAY}$

- BUILDING HEAT SUPPLIED $=50 \%$ OF REQUIREMENT

- BUILDING

$-72,000 \mathrm{FT}^{2}$

-PEAK ELECTRICAL SERVICE $=275 \mathrm{~kW}$ 


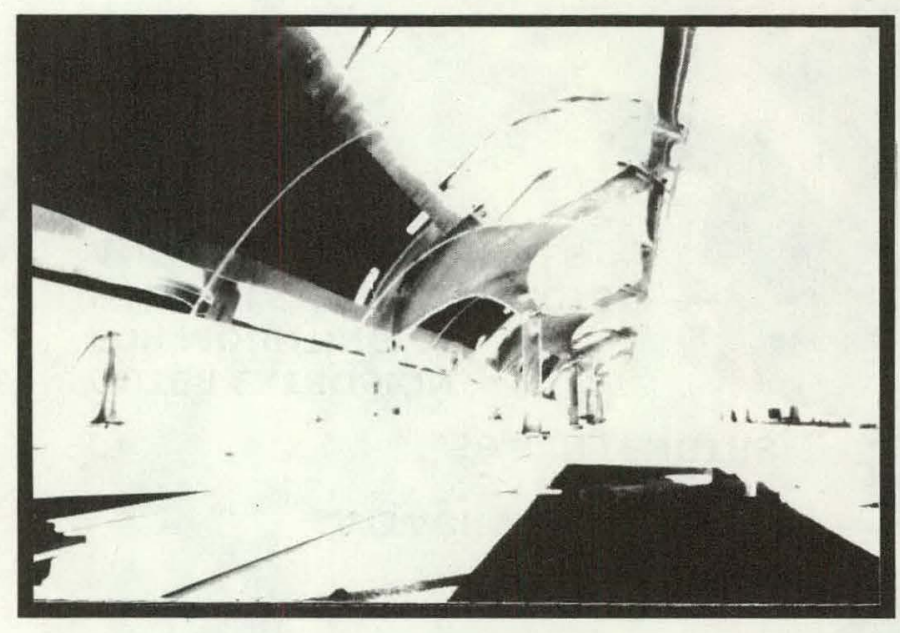

\section{ARRAY SPECIFICATIONS}

ARRAY AREA $\quad 7,560$ SO FT

7 FT APERTURE

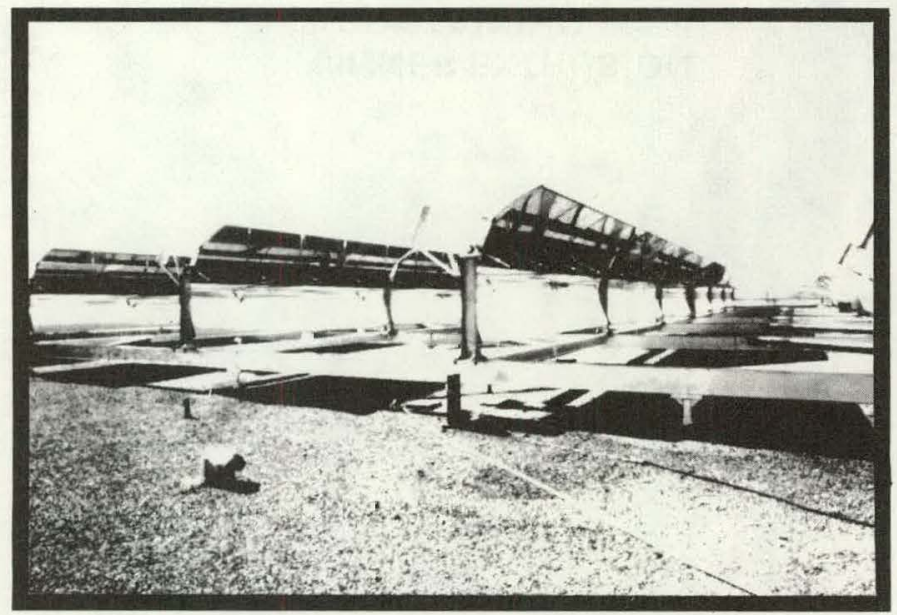

9 ROWS AT $\sim 3$ APERTURE SPACING

FEK-224 REFLECTANCE

ALUMINUM MONCOQUE CONSTRUCTION 


\section{CAPVC RECEIVER TUBE ASSEMBLY}

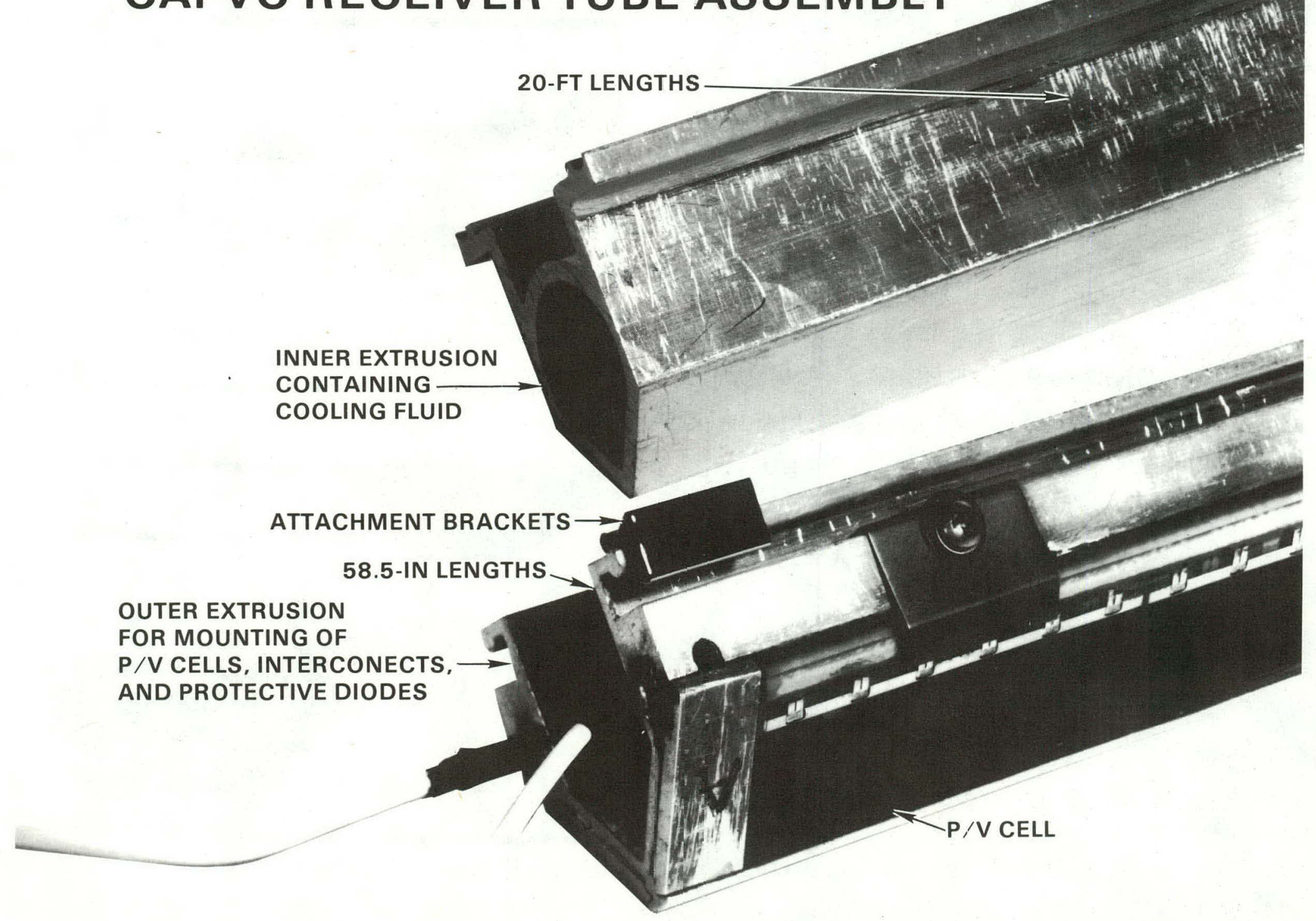




\section{CROSS SECTION}

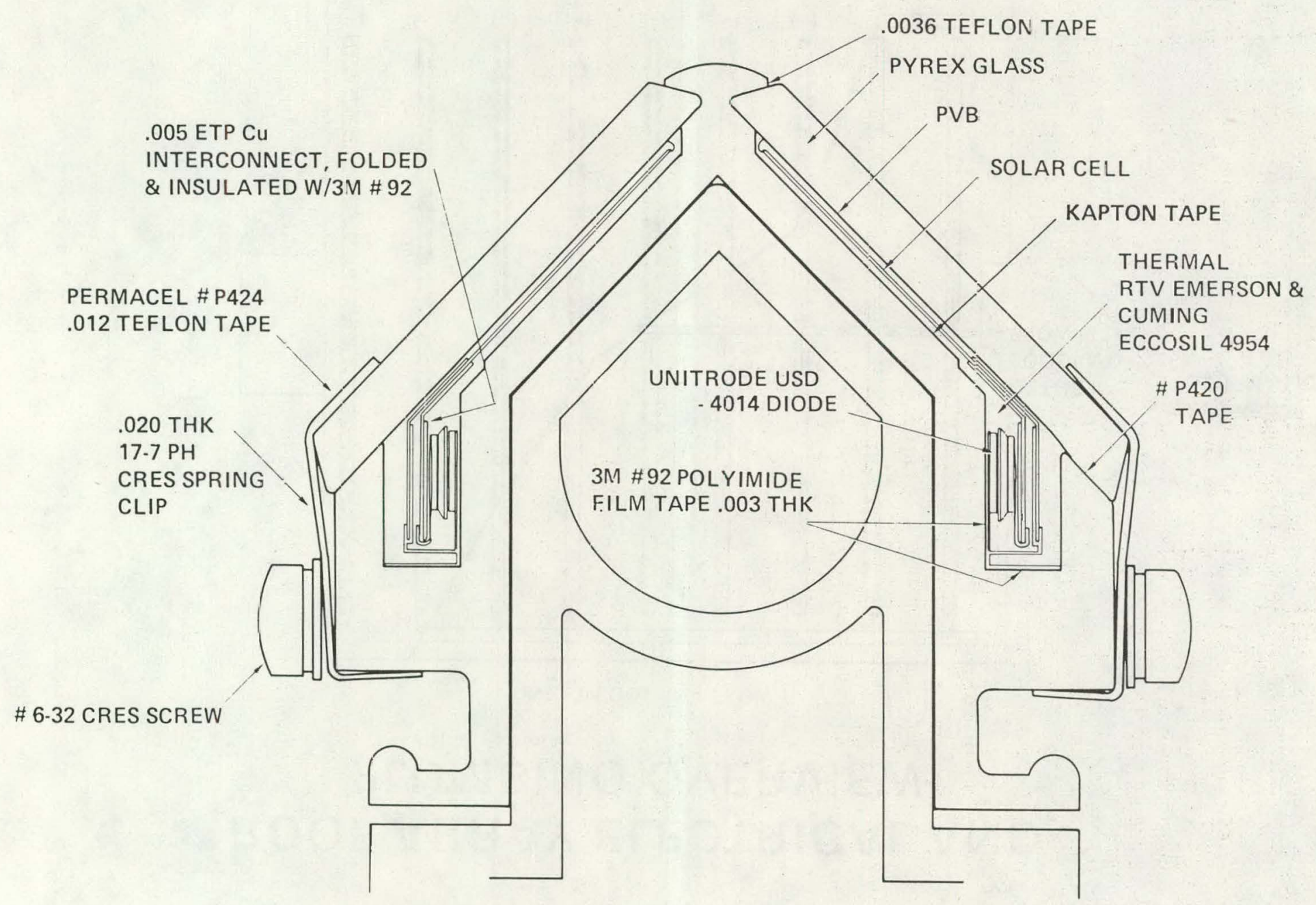




\section{ROOF ARRAY ELECTRICAL AND PLUMBING OVERVIEW}

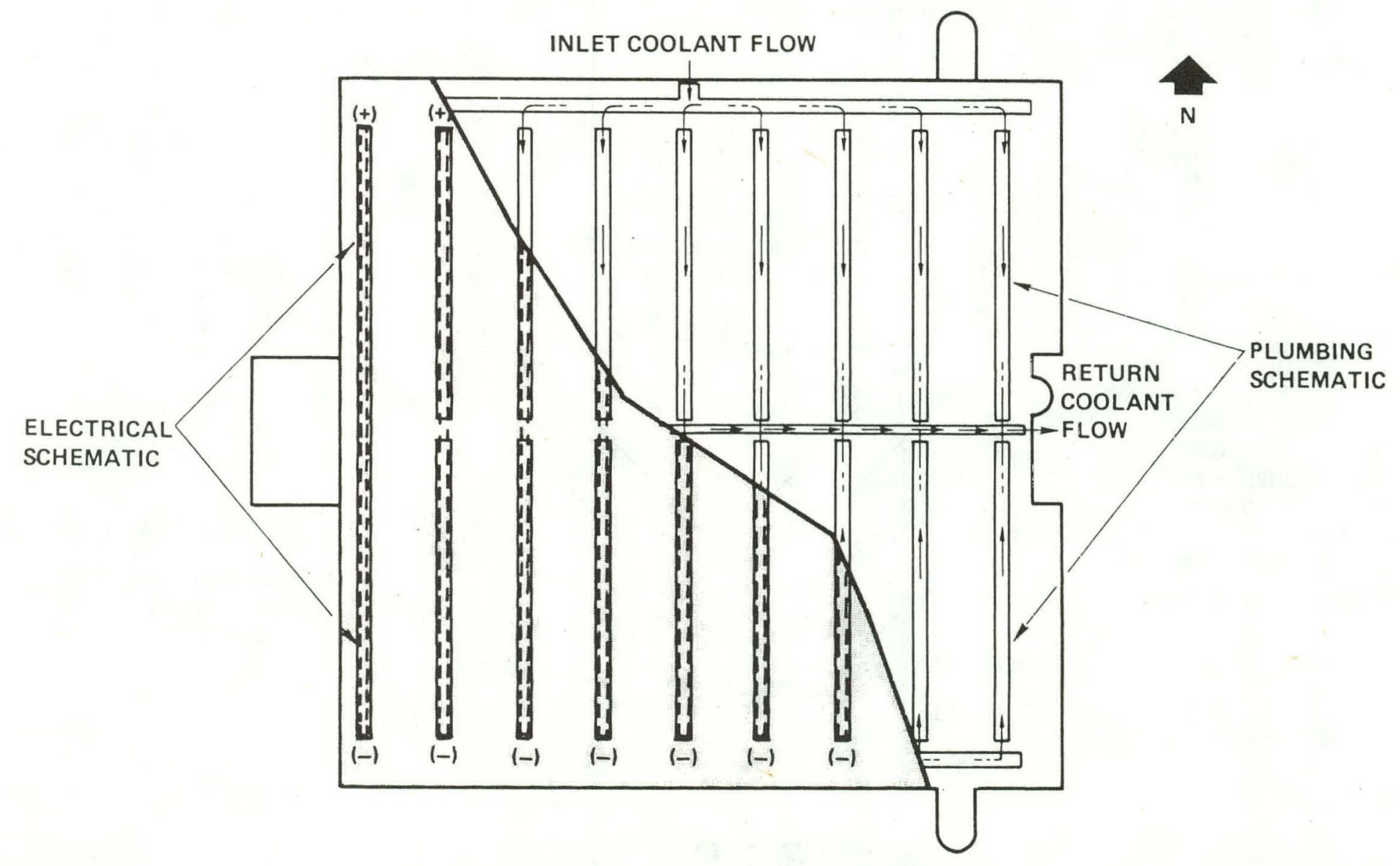




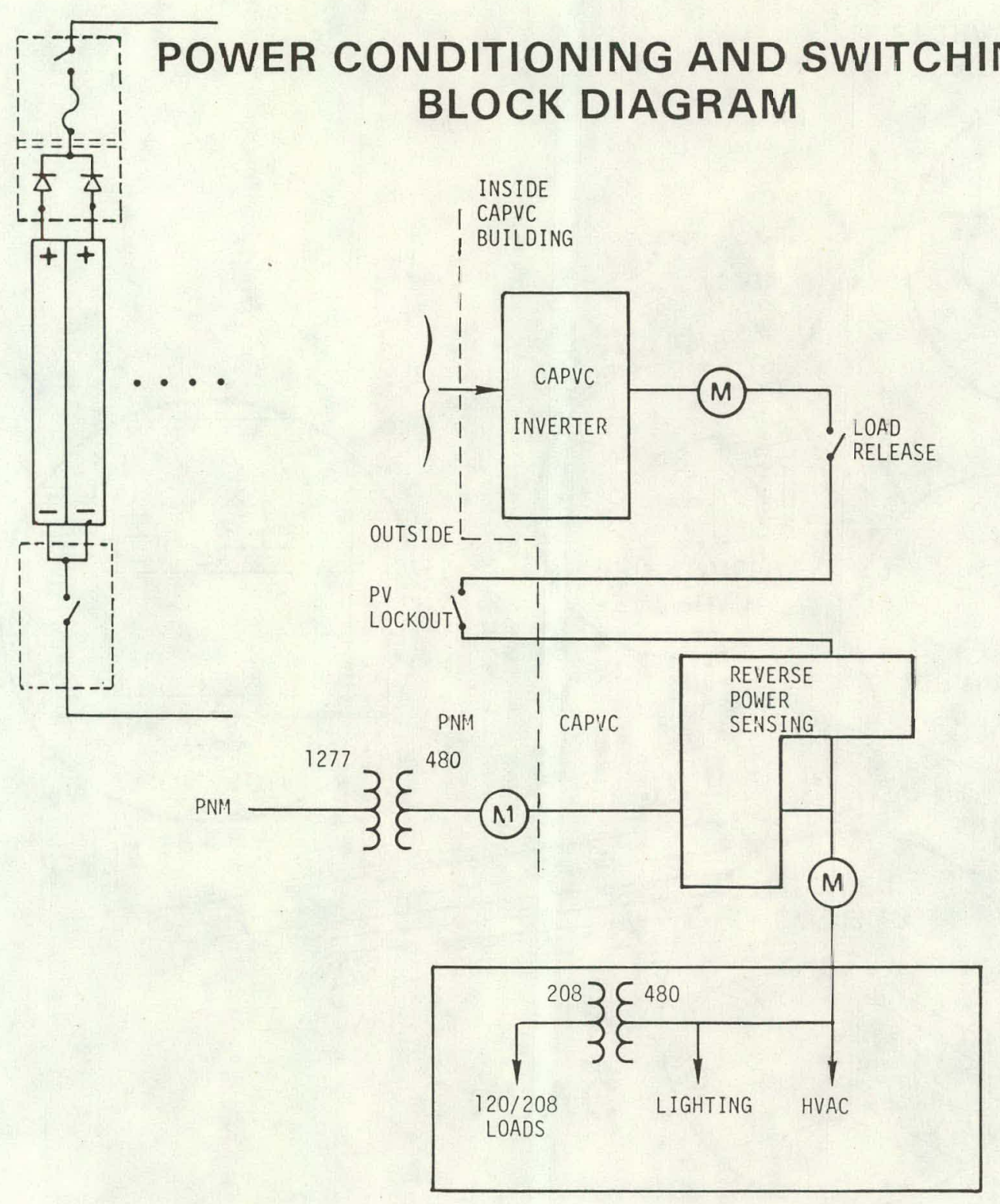




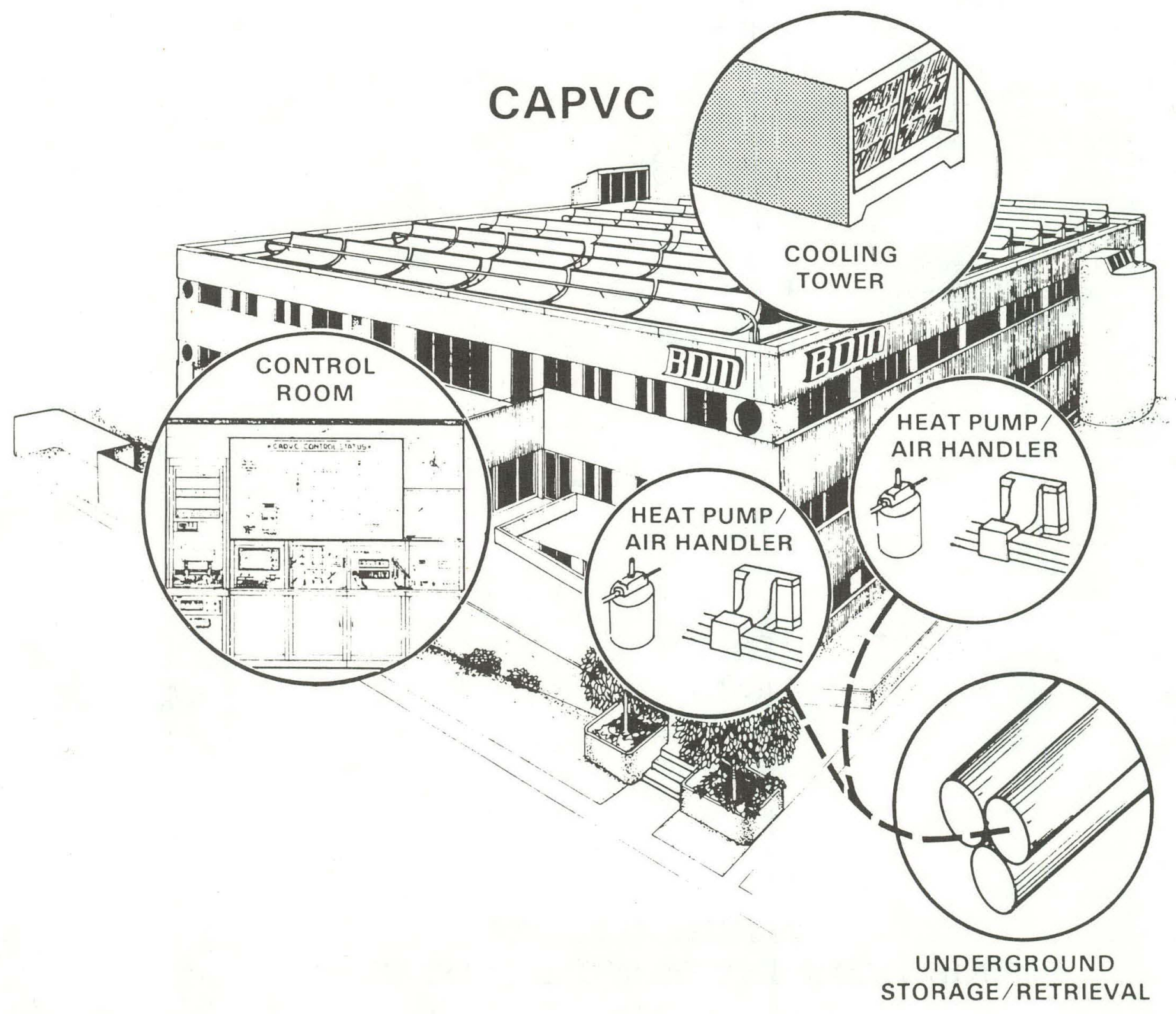




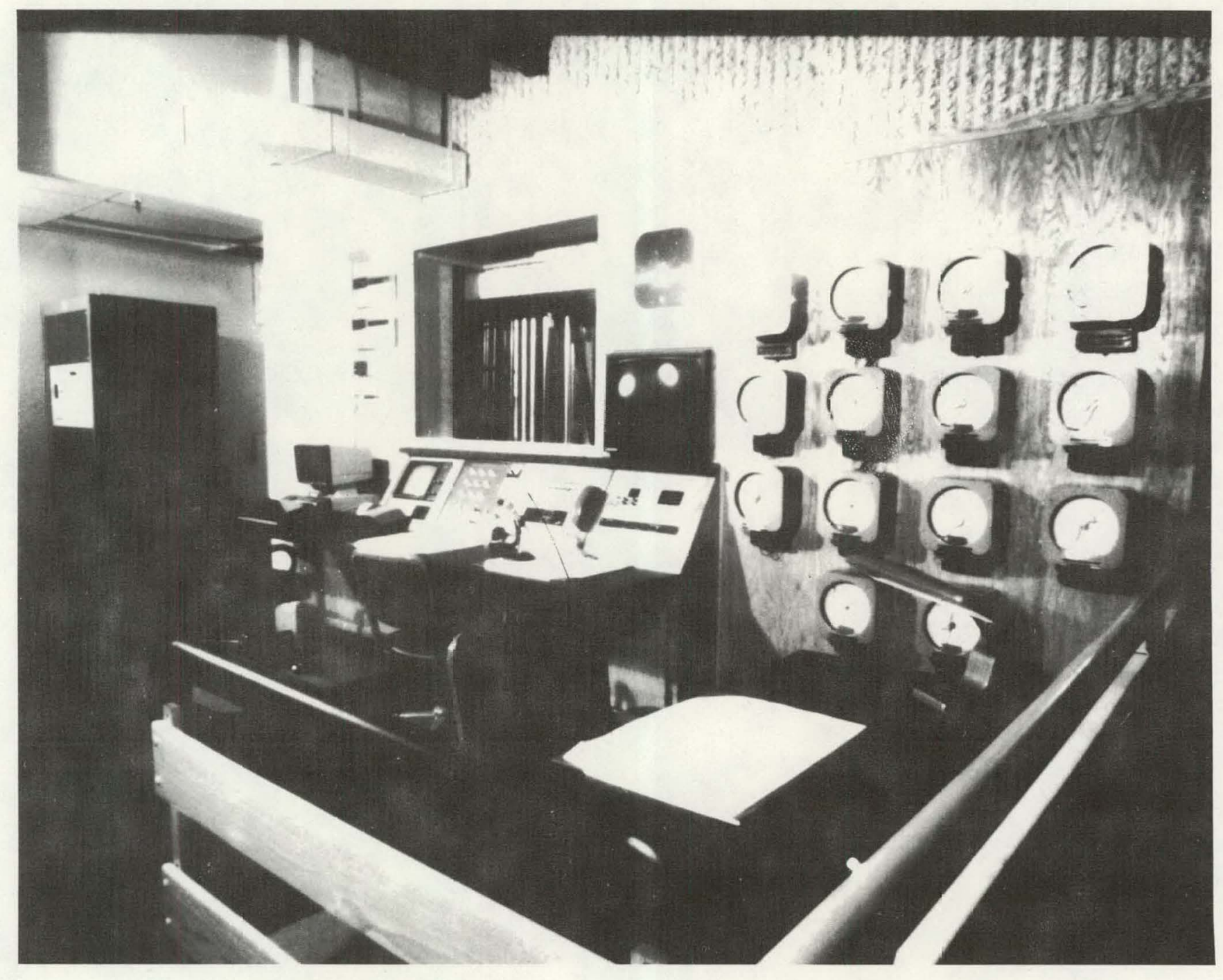


LINEAR FRESNEL LENS PHOTOVOLTAIC AND THERMAL SYSTEM AT THE DALLAS-FORT WORTH AIRPORT

\author{
By \\ M. J. O'Neill \\ E-Systems, Inc. \\ Energy Technology Center \\ P.0. Box 226118 \\ Dallas, Texas 75266
}

Since June 1978, E-Systems has been developing a combined photovoltaic/photothermal (PVT) power system for the Dallas.-Fort Worth (DFW) Airport, under the U.S. Department of Fnergy's Photovoltaic Application Experiments program. In 1978-79, we completed the design of the 27 kw (electric), $140 \mathrm{kw}$ (thermal) system. In 1980, we delivered qualification test collectors to Sandia National Laboratories - Albuquerque, where these collectors were thoroughly tested for performance, durability and lifetime. In 1981-82, we are manufacturing and installing the system, which will be operational by mid-year 1982 .

The Fresnel PVT system is currently being installed on the roof of the Central Utility Plant, which is centrally located at DFW Airport (Figure 1). As shown in Figure 2, the electrical power output will be used to supply a continuous-duty lighting load within the plant, while the thermal power output will be used to preheat low-temperature boiler feedwater used in a Rankine cycle power systern within the plant. The electrical interface utilizes a unique, $95 \%$ efficient, fully transistorized inverter, while the thermal interface utilizes a simple counterflow heat exchanger.

The solar collector field consists of 110 linear Fresnel lens PVT collector modules. Each collector module (Figure 3 ) utilizes a transmittance-optimized, short-focal-length, errortolerant, linear Fresnel lens as the optical concentrator. The single-piece, arched, acrylic lens ( $91 \mathrm{~cm}$ wide by $244 \mathrm{~cm}$ long aperture) focusses incident sunlight onto a seriesconnected string of silicon photovo?taic cells $(3.7 \mathrm{~cm}$ wide). The cells are mounted on an extruded copper, fin-tube heat sink, through which glycol/water coolant is circulated (Figure 4). During prototype collector testing, we discovered that collector electrical performance could be improved by about $10 \%$ by intentionally splitting/defocussing the lens such that each half of the lens provides a separate focal line of reduced concentration (Figure 5 ). Two collector modules (Figure 6) were subjected to a full set of qualification tests at Sandia in 1980. The Sandia-measured electrical efficiency results agreed with E-Systems measurements within about one part in one hundred (Figure 7). The total (electrical plus thermal) collector efficiency curve is shown in Figure 8 . The full qualification test series conducted by Sandia is shown in Figure 9 .

The DFW Airport PVT system will utilize our ten-collector-module array (Figure 10) as the basic building block. Eleven such arrays will be mounted on two levels of roof at the Central Utility Plant (Figure 11) to provide the full $245 \mathrm{~m}^{2}$ coilector field. Within each array of ten modules, hnth the electrical current and the coolant fluid will move in series through all ten collector modules. The eleven independent arrays will then be oardlieled luyether to provide the full system electrical current and fluid flow.

The currint status of the DFW Airport PVT Experiment program is summarized in Figure 12 . The system should be fully operational by this summer. 
E-SYSTEMS

Energy Technclogy Center
Photovoltaic Concentrator Application Experiment

FIGLIPE 1

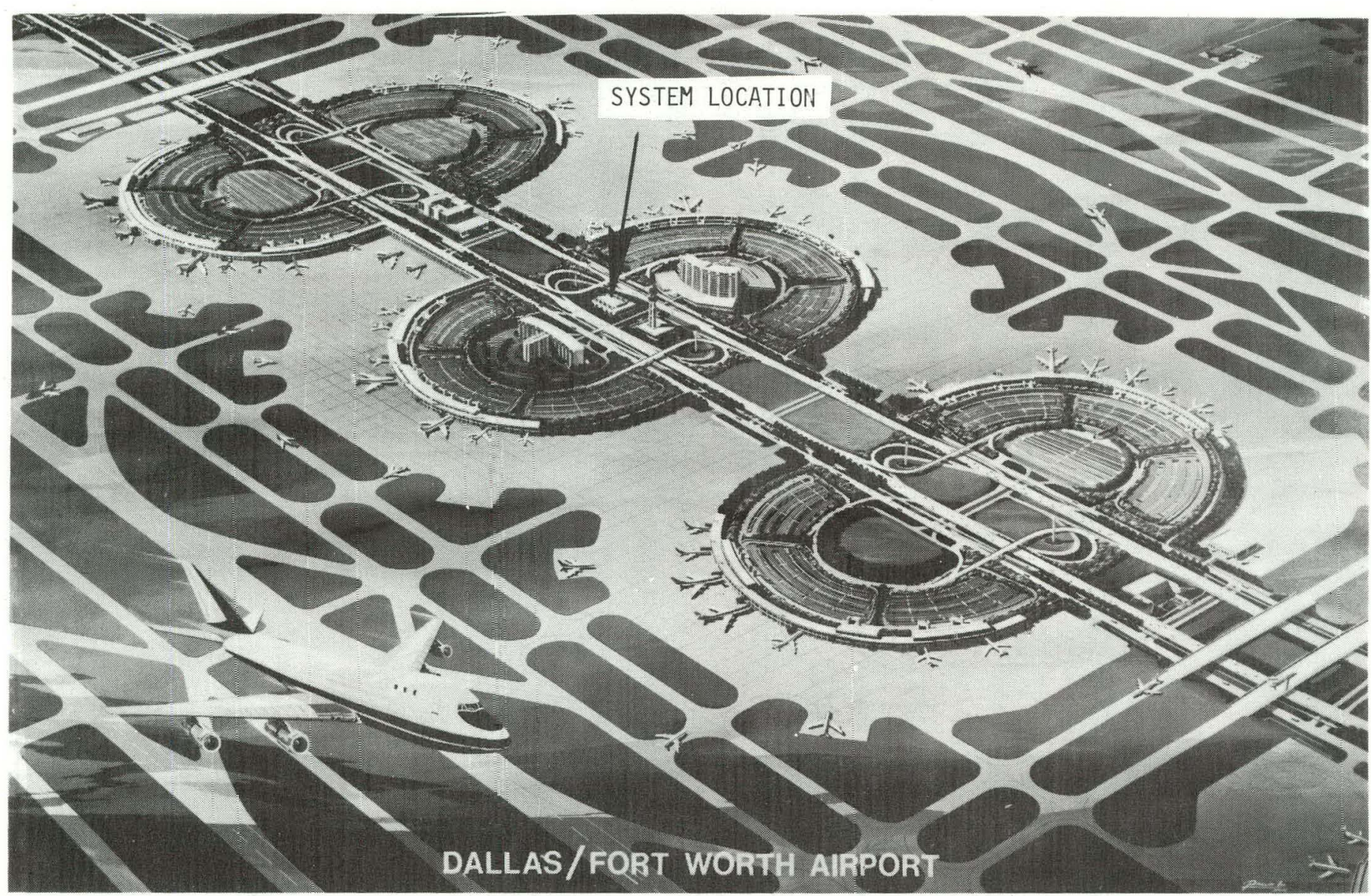


D/FW AIRPORT PHOTOVOLTAIC EXPERIMENT E-SYSTEMS

BLOCK DIAGRAM OF THE FRESNEL/PHOTOVOLTAIC/

Energy Technology Center PHOTOTHERMAL POWER SYSTEM

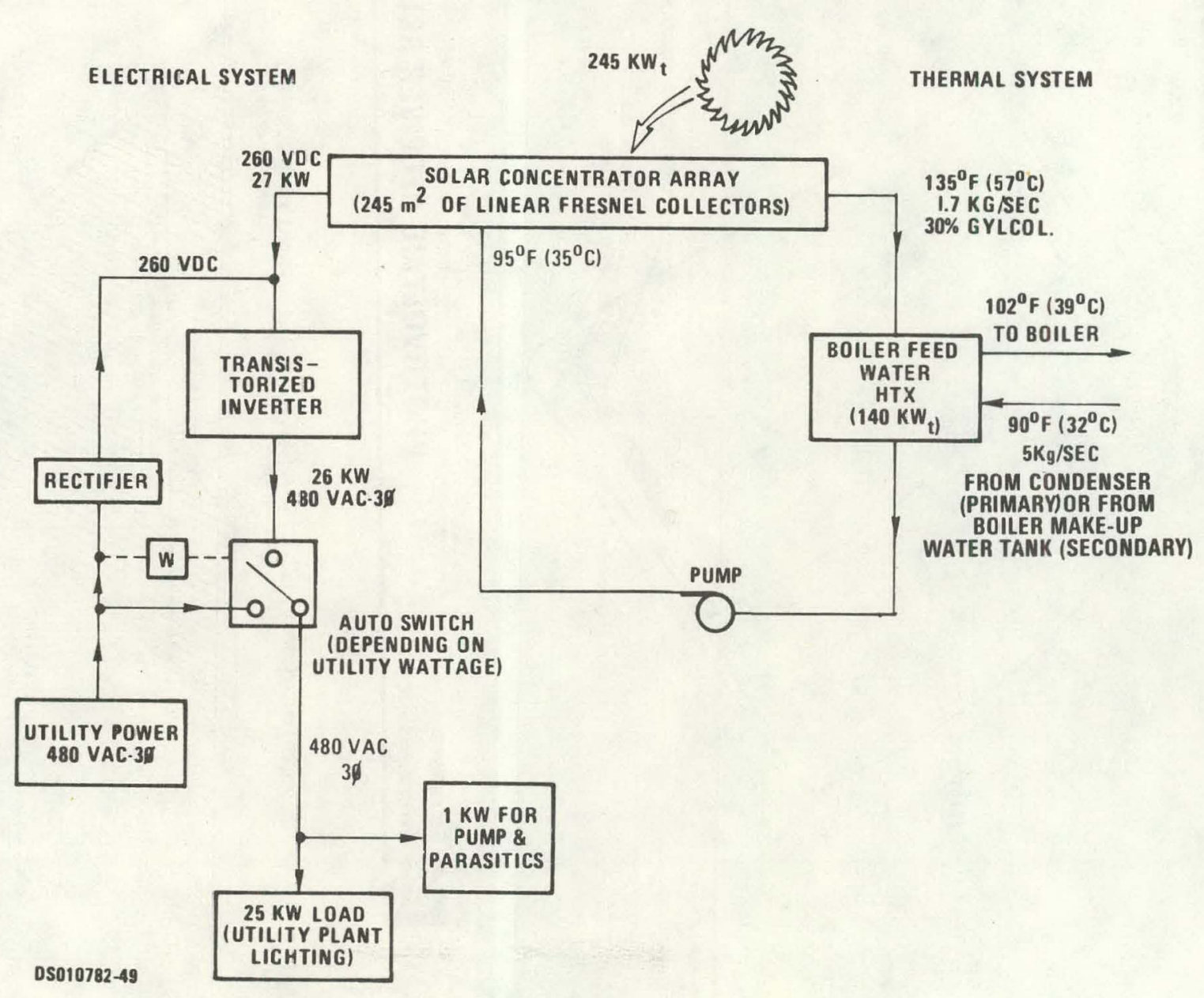

FIGURE 2 
FIGURE 3

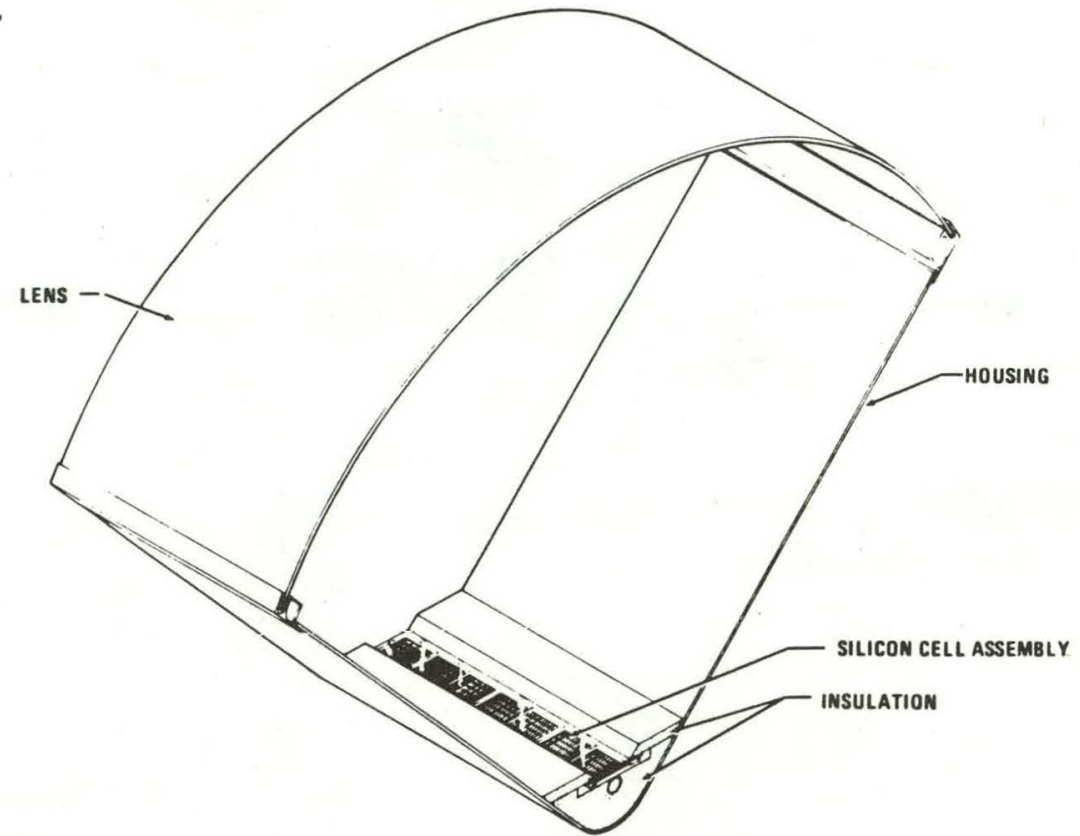

FIGURE 4

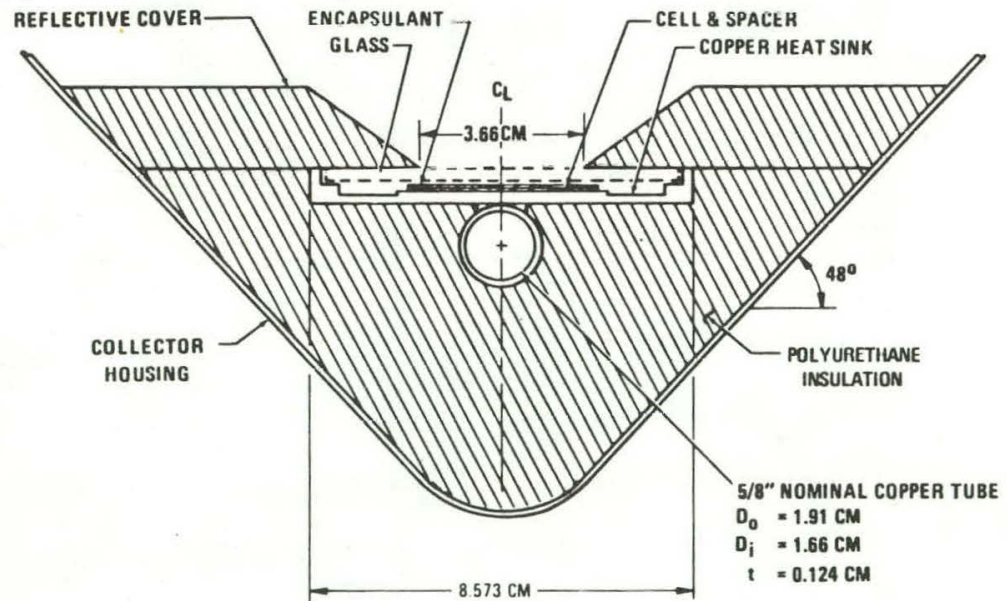




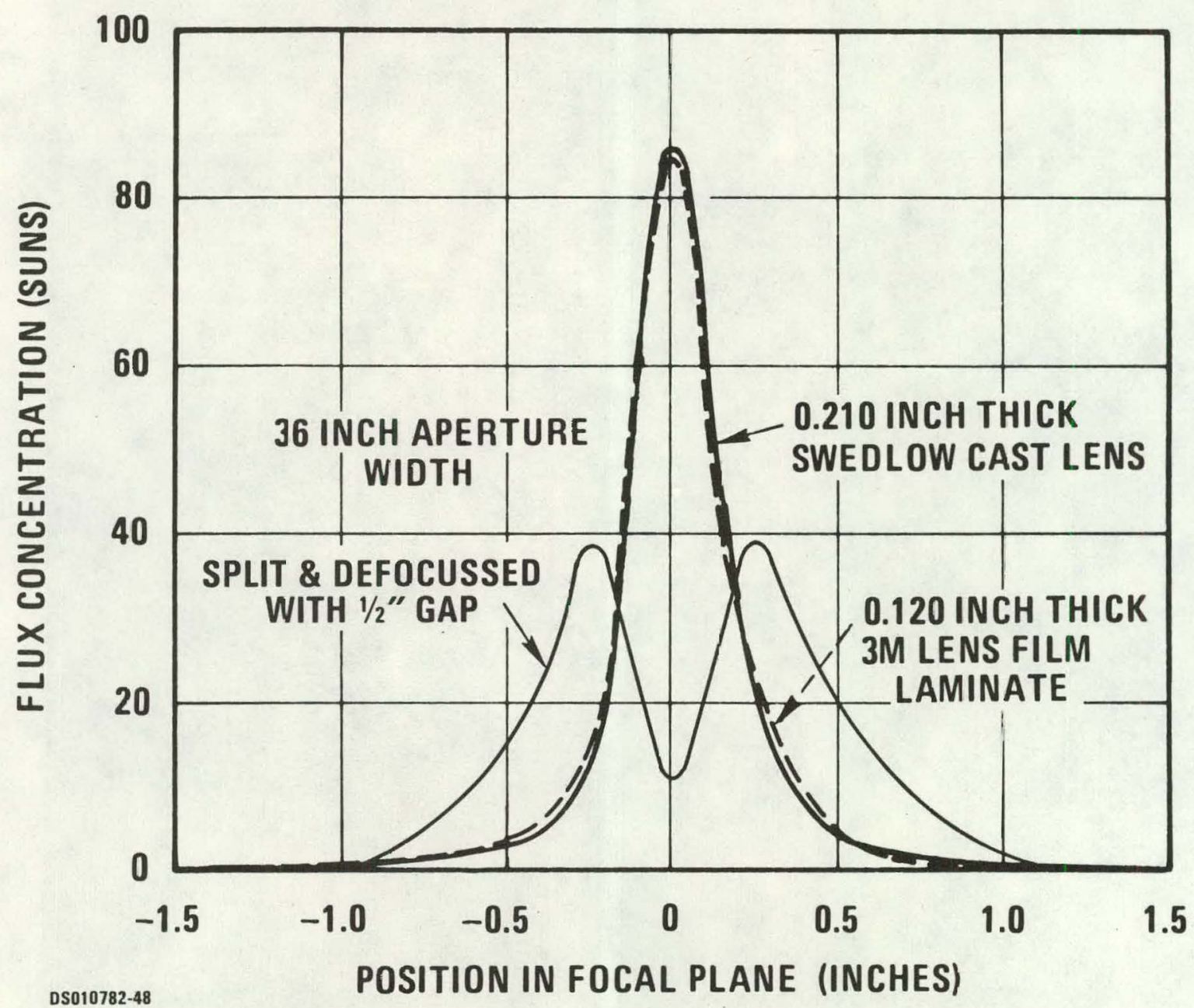

FIGURE 5 


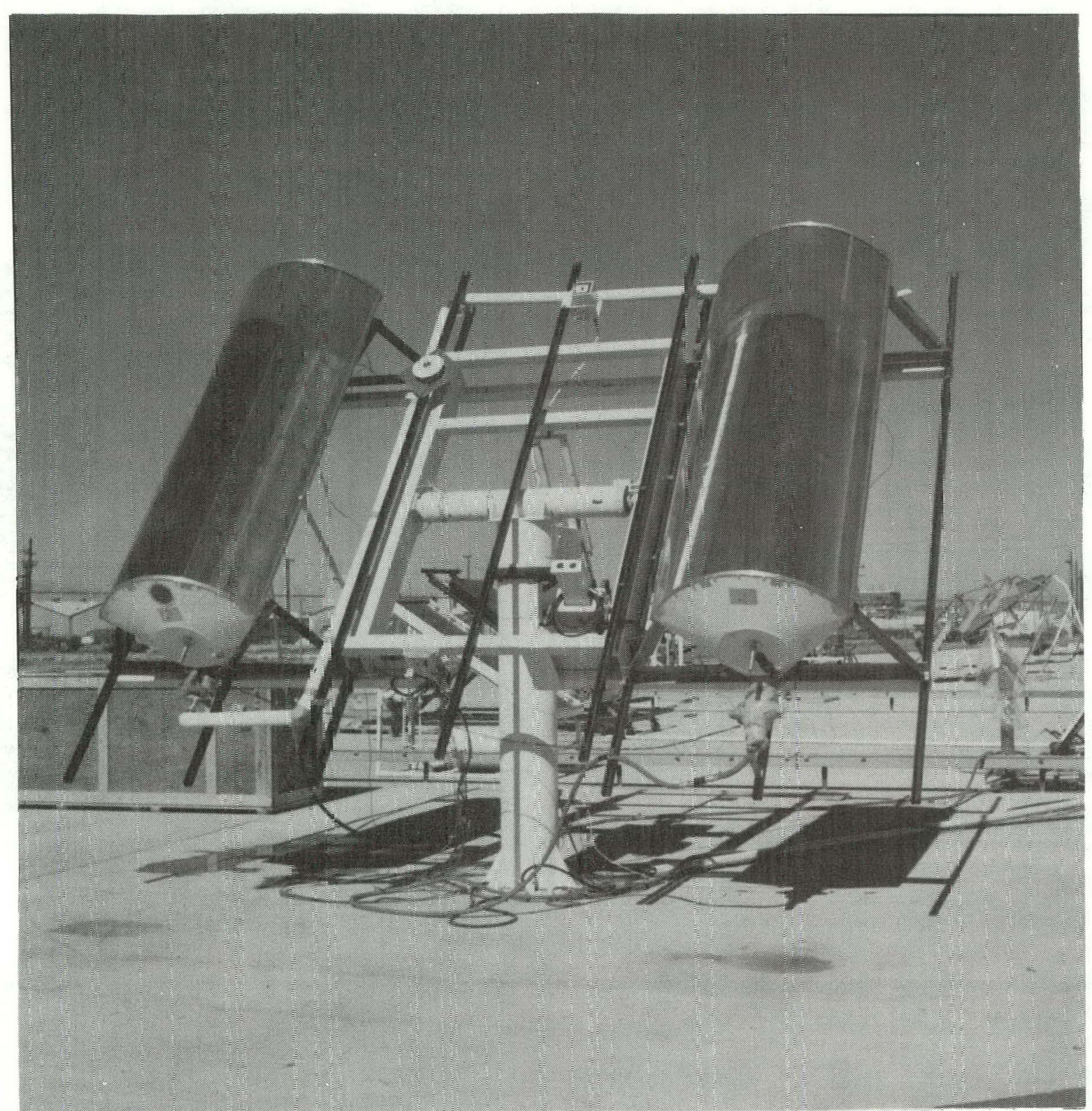

FIGURE : 

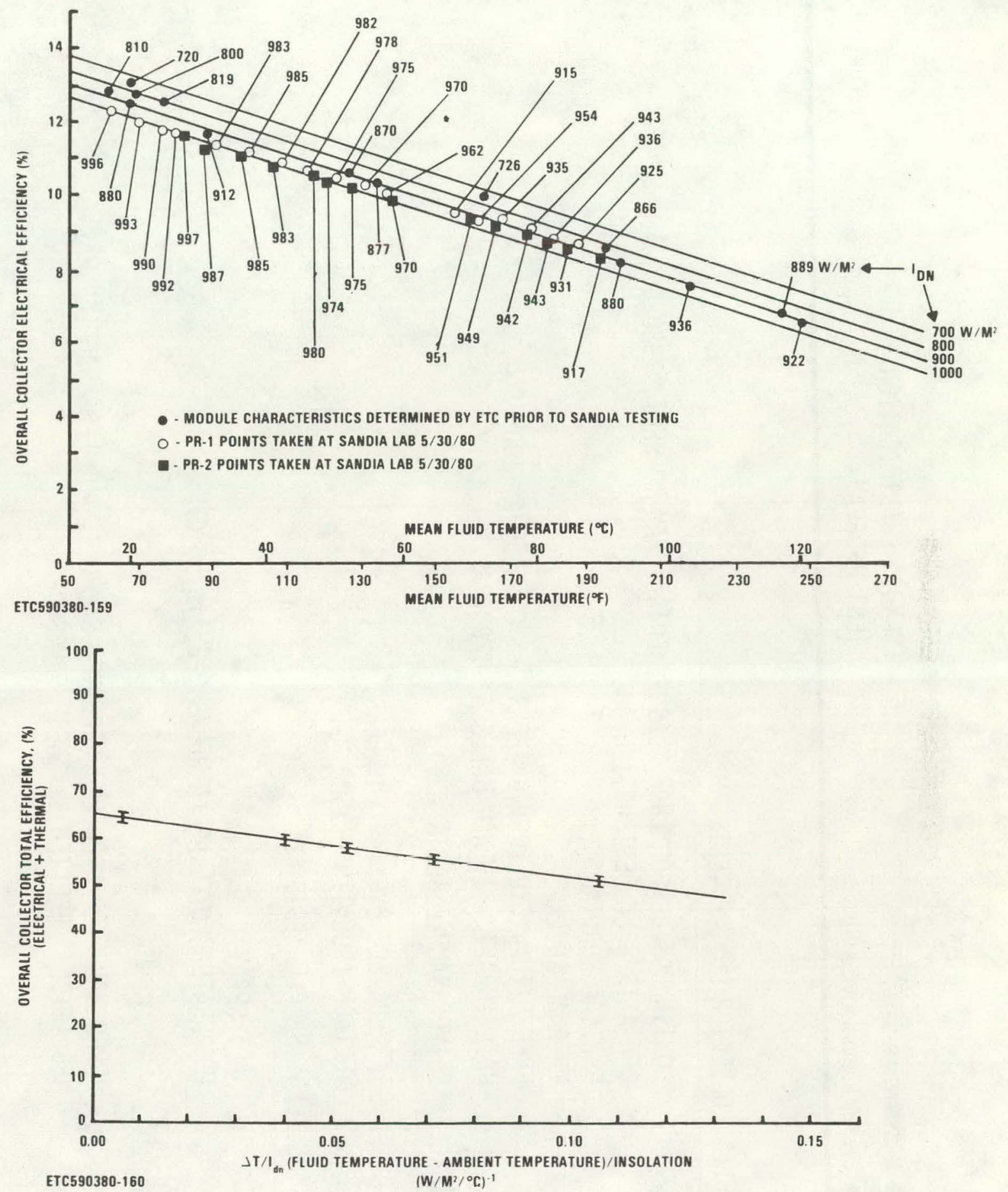

FIGURE 8 MEASURED TOTAL EFFICIENCY OF PRDA-35 QUALIFICATION MODULE 
FULL COLLECTOR MODULE TESTS

- CONTINUOUS PERFORMANCE MEASUREMENTS - MAY TO SEPT, 1980

- OFF-AXIS BEAM DESTRUCTION

- PARTIAL SHADING

- THERMAL SHOCK

- FREEZE/THAW CYCLING ( 4 WEEKS, $-6^{\circ} \mathrm{C}$ TO $55^{\circ} \mathrm{C}, 100^{\circ}$ R. $\mathrm{H}_{\text {. }}$ )

0 HAIL IMPACT - 1 INCH BALLS AT TERMINAL VELOCITY

SMALL RECEIVER SAMPLE TESTS

- TEMPERATURE CYCLing ( 4 WEEKS, $-6^{\circ} \mathrm{C}$ to $120^{\circ} \mathrm{C}$ )

- VOLTAGE ISOLATION (1500 VDC)

SMALL LENS SAMPLE TESTS

- SALT SPRAY

0 TEMPERATURE CYCLING ( 4 WEEKS, $-6^{0}$ TO $50^{\circ} \mathrm{C}$ )

RESULTS

- PERFORMANCE OF MODULES, RECEIVER SAMPLES, AND LENS SAMPLES WAS NEGLIGIBLY AFFECTED BY THESE EXPOSURES 


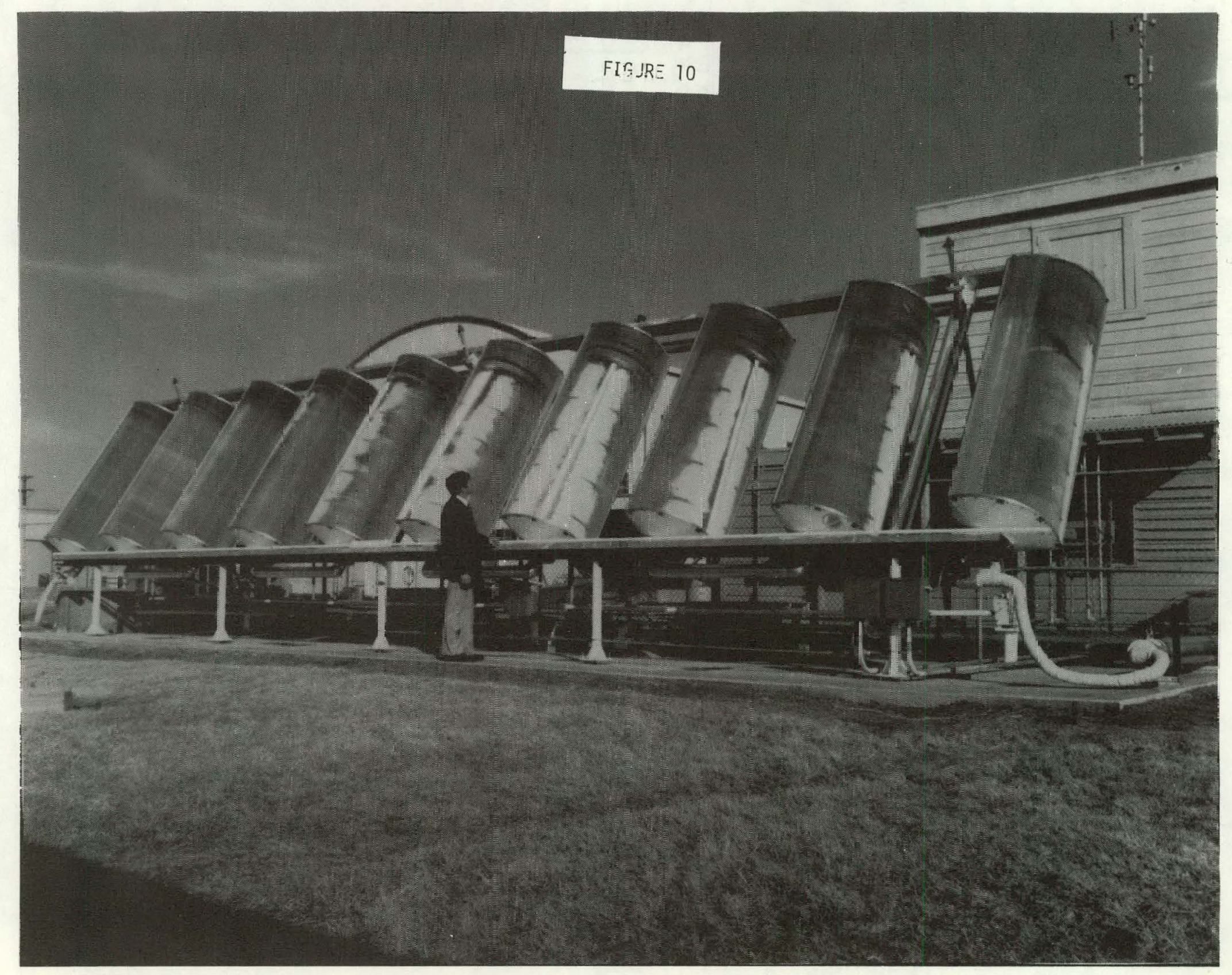


E-SYSTEMS

Energy Technology Center

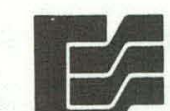

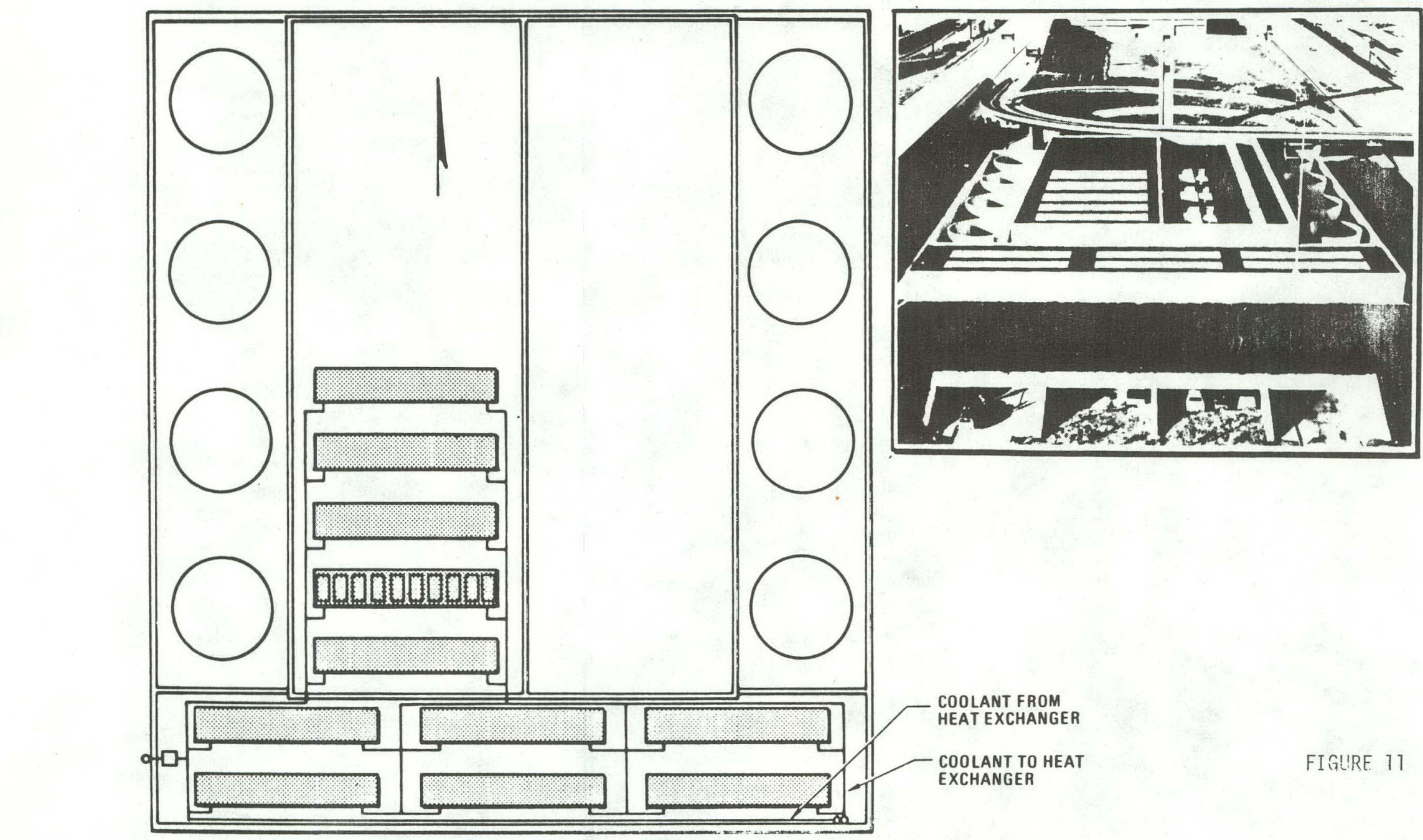

\section{KW DALLAS/FORT WORTH
AIRPORT PHOTOVOLTAIC SYSTEM \\ 25 KW DALLAS/FORT WORTH
AIRPORT PHOTOVOLTAIC SYSTEM}

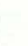


- ASEC WILL COMPLETE DELIVERY OF PV RECEIVERS IN FEBRUARY 1982.

- E-SYSTEMS WILL COMPLETE SYSTEM MANUFACTURING IN MARCH 1982.

- SYSTEM INSTALLATION WILL BE COMPLETED IN MAY 1982.

- SYSTEM INITIAL OPERATION AND CHECKOUT WILL OCCUR IN MAY 1982.

- 30 DAYS OF SYSTEM OPERATION WILL OCCUR IN JUNE 1982.

- PHASE II FINAL REPORT WILL BE SUBMITTED IN JULY 1982. 
PHOENIX SKY HARBOR AIRPORT

PHOTOVOLTAIC CONCENTRATOR PROJECT

W. Joseph McGuirk

Arizona Public Service Company

P.0. Box 21666, Phoenix, Arizona 85036

\section{ABSTRACT}

This Photovoltaic Concentrator Application Experiment, one of four concentrator projects currently sponsored under DOE'S PRDA-35 program, is entering the final stages of construction. March 12, 1982 has been targeted for completion of component acceptance and start of the 30-day system performance run. The 225 peak kW array field is comprised of 80 Martin Marietta passively cooled tracking arrays, which feed a Power Systems and Control inverter. The a.c. output is stepped up to 12.6 KV and fed directly into the APS power grid at the Airport site. Monitoring of specific load data at the Airport's Terminal 3 will be accomplished during Phase III in conjunction with collection of the PV system's performance data in order to establish solar's capability to satisfy a specific load pattern with a concentrating PV converter.

The Martin Marietta concentrator module design is identical, with minor exceptio:as, to the hardware supplied to the $350 \mathrm{~kW}$ Saudi Arabian village project under the SOLERAS program. Early operating experience from that system is expected to benefit the Sky Harbor operation. The concentrator utilizes a Fresnel lens to focus energy (36X) on a 2.25 inch diameter silicon solar cell. A total of 272 lens-cell combinations are mounted onto a pedestal mounted two-axis tracking array structure.

During the Phase I design activity a computer program was utilized to predict the performance of a $500 \mathrm{~kW}$ concentrator photovoltaic system. To the extent that those results are applicable to the installed system, which is a reasonable assumption, the expected annual energy output is 440,000 kW hours . 


\section{AIRPORT SOLAR PHOTOVOLTAIC CONCENTRATOR PROJECT ORGANIZATION}

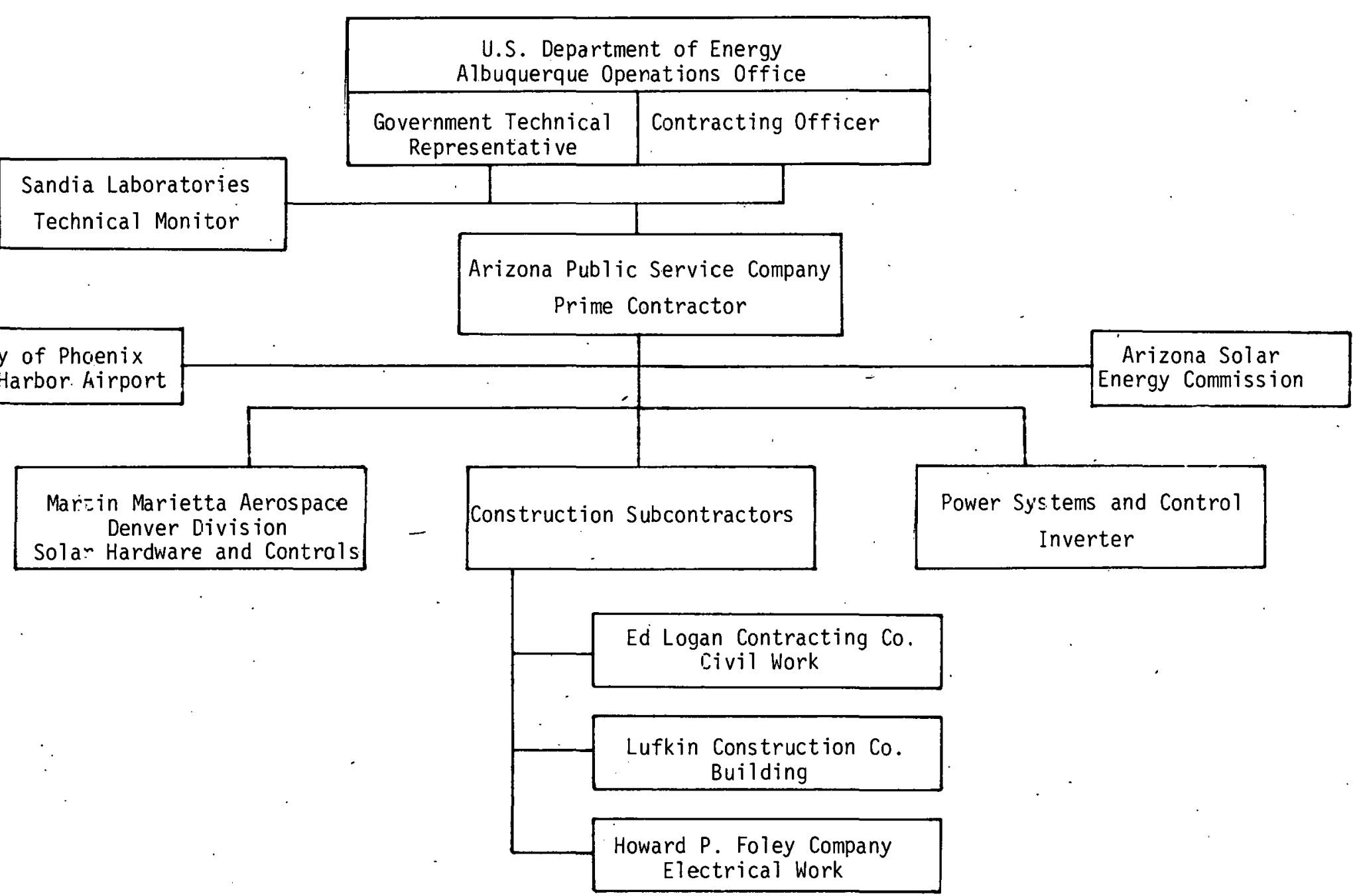




\section{ASPCP SYSTEM LEVEL SPECIFICATIONS - SHEET 1}

$\begin{array}{ll}\text { Single Fresnel lens } & - \text { Cell Unit, Peak Output: } \\ \text { Voltage } & 0.465 \text { volts } \\ \text { Current } & 22.3 \text { amps } \\ \text { Power } & 10.3 \text { watts }\end{array}$

Module:

Number of Lens - Cell Units Per Module

ARRAY:

Number of Modules

Per Array

Number of Lens - Cell

linits Per Array

ARRay Power OUtPut

2,821 WATTS 
ASPCP SYSTEM LEVEL SPECIFICATIONS - SHEET 2

\section{String:}

Number of Arrays

Per String

NuMBer of Strings

PER FIELD

Lens - CELL . Linits

Per String

String Voltage

String Power Output

ARRAY FIELD:

Field Dimensions

Field Area

Number of Arrays

PER FIELD

Number of Cells

PER FIELD

Field Power 0utput
$2-1 / 2$

32

630

316 VOLTS D.C.

$7,047 \quad$ WATTS

$451 \mathrm{FT}, \quad(E-W)$

$\times 447 \mathrm{FT}, \quad$ (i)-S)

4.6 ACRES

80

21,760

$225.5 \quad \mathrm{~kW}$ 


\section{ASPCP SYSTEM LEVEL SPECIFICATIONS - SHEET 3}

SYSTEM LOSSES :

ARRAY AND FIELD WIRING

INVERTER

\author{
SYSTEM OUTPUT: \\ INVERTER INPUT \\ VOLTAGE \\ INVERTER INPUT \\ CURRENT \\ INVERTER INPUT \\ POWER \\ INVERTER (SYSTEM) \\ OUTPUT POWER
}

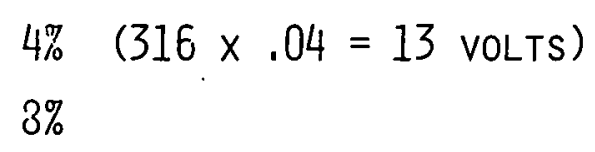

303 VOLTS

$714 \quad$ AMPS $(22.3 \times 32)$

$216.2 \quad \mathrm{k} !$

$198.9 \mathrm{~kW}(216.2 \times .92)$ 


\author{
J. L. Jackson \\ PV Systems Definition Division \\ Sandia National Laboratories \\ Albuquerque, NM 87185 :
}

\begin{abstract}
$\underline{\text { Abstract }}$
We have divided our efforts in PV Systems Research into three main areas - residential, intermediate and central station.

Key results from residential research suggest that simple, grid interactive designs are most appropriate for residential applications. Homes with PV should use inexpensive fuels and load reduction techniques where practical. Based on "zero net energy use" (i.e., the PV system produces as much energy as the house uses on an annual basis), $4 \mathrm{kWp}$ and $8 \mathrm{kWp}$ array sizes appear most feasible for PV residences. In addition, utility interface requirements will likely dictate the design of the PCS.

Intermediate systems are likely to represent the largest potential near term market for PV. Other important conclusions from research in this sector indicate that applications which use dc only appear. somewhat limited. Therefore, most intermediate PV systems in the future will probably utilize an inverter. In addition, intermediatesized retrofits appear most feasible for public sector buildings, including schools, hospitals, and government facilities. Preliminary results also suggest that intermediate-sized applications which use the electrical and thermal energy produced by actively cooled PV concentrators are very attractive.
\end{abstract}

Two central station test facility design studies were published in 1979 which addressed utility test and hardware requirements, and design trade-offs. This was followed by the subsystem trade-off work, which was recently completed. In that effort, array voltage, power conditioning size, and wiring considerations were analyzed parametricaliy to deterimine the most eoonomical and energy efficient large field design. A plant design using 2000 vdc bipolar array subfields which feed 5 MWp power conditioners appears quite feasible. Results from the subsystem study, and from other appropriate balanceof-system activities are currently being utilized in another design. study for a 100 MW facility typical of 1990 installation. This study will produce two reference design documents - one flat plate, one concentrator - for a specific site in Arizona. While there is no intention of actually building the resultant systems designs, this study should provide detailed information for future work and identify subsystem iscues.

Future work in systems research will include completing existing contracts and compiling and summarizing key design issues in a series of topical reports. 


\section{Key Results Residential Sector}

田Sandia National laboratories

- Most promising systems are simple, grid-interactive designs

- House designs should use inexpensive fuels and load reduction techniques where practical

- Based on "zero net energy use" $4 \mathrm{~kW}_{\mathrm{p}}$ and $8 \mathrm{kWp}$ sizes appear appropiate

- Utility interface requirements will dictate power conditioning subsystem

- Residential Retrofit market appears smaller than previously thought 
61. Sandia National Laboratories

\section{Key Results \\ Intermediate Sector}

- Largest Potential Near Term Market

- Straight DC applications somewhat limited

- Retrofits attractive for public sector buildings

- Total Energy systems appear very attractive 


\section{A. Thandia National Laboratories}

\section{Key Results Central Station Sector}

- No major driver for in-field voltage over 200 VDC (or \pm 1000 VDC)

- Subfield size of approximately $5 \mathrm{MW}$ appears optimal

- Soil resistivity should be a key element in site section 


\section{SOL.AR PHOTOVOLTȦIC RESIDENTIAL PROJECT * $* *+$}

$$
\text { E. C. Kern, Jr. }
$$

Massachusetts Institute of Technology

Lincoln Lahoratory

Lexington, Massachusetts 02173

\section{ABSTRACT}

Residential systems development and testing for the.H.S. Department of Energy's Photovoltaic Energy Systems Division has been conducted by the Massachusetts Institute of Technology Lincoln Laboratory since early 1977. After an initiai effort to design stand-alone photovoltaic (PV) systems in the spring of 1977, work was delayed until a consensus was reached in 1978 to focus residential efforts on grid-connected systems having no on-site energy storage devices. Such systems, while not early favorites, have gaincd considerable credibility owing to the enactuent of the Public Utilities Regulatory Policy Act of 1978, which mandates Lhat small power-producing facilities sell electricity to utilities at the ulilicies' marginal cost and purchase energy at the utilities' average (standard) cost.

In the winter of 1979 , Lincoln Laboratory prepared a plan for residencial system development and testing that called for the establishment of Residential Experiment Stations (RES) in the Northeast, Southwest and Southeast regions of the United States. In the ensuing three years, thirteen residertial systems have been built at the Northeast and Southwest RESs, a complete PV-equipped house has been built in the Northeast and other grid-connected PV systems have been installed on homes in Arizona, Florida and Hawaii. The federal program has also spawned the first privately financed "spec house" equipped with grid-connected photovoltaics (now nearing completion in Santa $\mathrm{Fe}$ and to be dedicated in Februaty 1982).

Performance for all the Lincoln Labocatory systems is being monitored and reported according to procedures which will enable homeowners and utilities to assess fully the signif1cance of these systems. Power levels and energy flows are sampled every five seconds at each of the PV systems and at an approximately equal number of "monitored" houses in order to obtain real load data from which to ascertain exact energy exchanges. This enables the assessment of varlous revenue rate structures based on each of the monitored holses theoretically being equipped with each of the PV systems. Additional power flow data are gathered on distribution feeders near each RES in order to assess the likely effects of PV generation on the operation and control of utility power distribution equipment. Early results for these measurements are presented and plans for concluding the assessment of these systems are described.

Lincoln Laboratory has also been active in research pertaining to the integration of photovoltaics into the nation's electric grid and its acceptance in the residential marketplace. Work done in the former area is being presented by Professor Jack Fitzer of the University of Texas at Arlington at this meeting. (Up to 30\% penetration of the houses in a residential nelghlurhood does not appear to cause major tecinical problems.) Other work, being conducted by Professor Martin Katzman at the University of Texas at Rlchidison, fosuses on the value of PV generation in a utility's generation mix and has frovided results far more encouraging for photovoltaics than similar studies conducted at Argonne National Laboratories (reported in Science magazine last summer).

Finally, MIT Energy Laboratory has performed various worth and market analyses for the profect. These include the collection of raw data on the size and number of potential retrofit. residential opportunities cxtant in the United States, an assessment of the state of the art in forecasting housing inventories on a regional basis in cooperation with the llarvard/MIT Joint Center for Urban Studies, and the develupment of a market-survey instrument for assessing the likelihood of purchase of residential PV systems given breakeven homeowner econonics.

*Sponsorea by the U.S. Departmen: of Energy.

* The U.S. Government assumes no responsibility for the work presented.

+Submitted to the Third Photovoltalc Systems and Applications Project Integration Meeting, Aibuquerque, NM, S-11 February 1982. 
SANDIA PHOTOVOLTAIC

RESIDENTIAL PROJECT

Kent L. Biringer

Sandia National Laboratories

P. O. Box 5800

Albuquerque, NM 87185

Sandia National Laboratories has been selected as the new photovoltaic (PV) Residential Project Manager (RPM) for the Department of Energy PV Residential Project. The Sandia involvement began in October 1981 and will continue to increase as the work of MIT Lincoln Laboratory is gradually phased out during fiscal year (FY) 1982.

One of the first Sandia residential PV activities has been to establish two review committees. The first of these is the PV Residential Task Group made up of representatives from federally supported programs at national laboratories. The second review committee is the PV Residential Overview Committee which includes industry and government participants. The non-government members include PV system integrators and designers, array and other component manufacturers, utilities and universities. Together these groups provide input and feedback to the project planning activities of the RPM.

Currently, a multi-year PV residential project plan is being prepared. The plan is being structured to maximize the transfer of information to industry as the role of the federal program changes from a broad based program to one of focused R\&D. The FY82 and FY83 activities will emphasize bringing to a logical conclusion many of the current activities. Some selected new initiatives are also envisioned during this transition period.

The residential project has been divided into four categories. These are systems research, array subsystem, power conditioning subsystem, and system experiments. The planning activities have been organized around these categories. The attached vugraphs present the objectives and major milestones for the residential project at this time. The information presented here is still preliminary and has not yet been finalized or approved by the Department of Energy. Other activities including specially directed projects have not, yet been reflected in the plans. 
NEW ADMINISTRATION GUIDELINES

DOE SOLAR Activities

- Shift Focus Away From near-Term Development, Demonstration, and

Commercialization Efforts and into Longer-Range Rrd Projects that Are

too Risky for Private Firms to Undertake

- Developing Marketable Systems Once Technical Feasibility is Established is Responsibility of Private Sector

SECRETARY OF ENERGY

Memorandum 
1. Bring Present Activities to a Logical Conclusion

2. Spend Significant Effort dn Documenting Experience for Transfer to Industry

3. Carefully Select New Initiatives That Emphasize High Risk Technology Questions of Significant Concern to Industry and Beyond Current Industry Planning

4. Develop a Low-Level Continuing Effort to Provide Support for a Focused Red Program 
OBJECTIVE

ADVANCE THE DEVELOPMENT AND SCIENTIFIC UNDERSTANDING OF SMALL RDOF-MOUNTED PV SYSTEM TECHNOLOGY AS A SIGNIEICANT RENEWABLE ELECTRIC ENERGY OPTION. FOR the U.S. The Residential Project will emphasize establishing a technology BASE NEEDED TO PERMIT MEANINGFUL RISK ASSESSMENT BY PRIVATE FIRMS FOR INTRODUCING THE GRID-CONNECTED RESIDENTIAL PV OPTION INTO THE ENERGY SUPPLY MIX.

APPROACH

CONDUCT:

- System REsearch

- PV ARray Subsystem R\&D

- Power Conditioning Subsystem R\&D

- Selected System Exferiments 
PHOTOVOLTAIC RESIDENTIAL PROJECT

MAJOR MILESTONE SCHEDULE

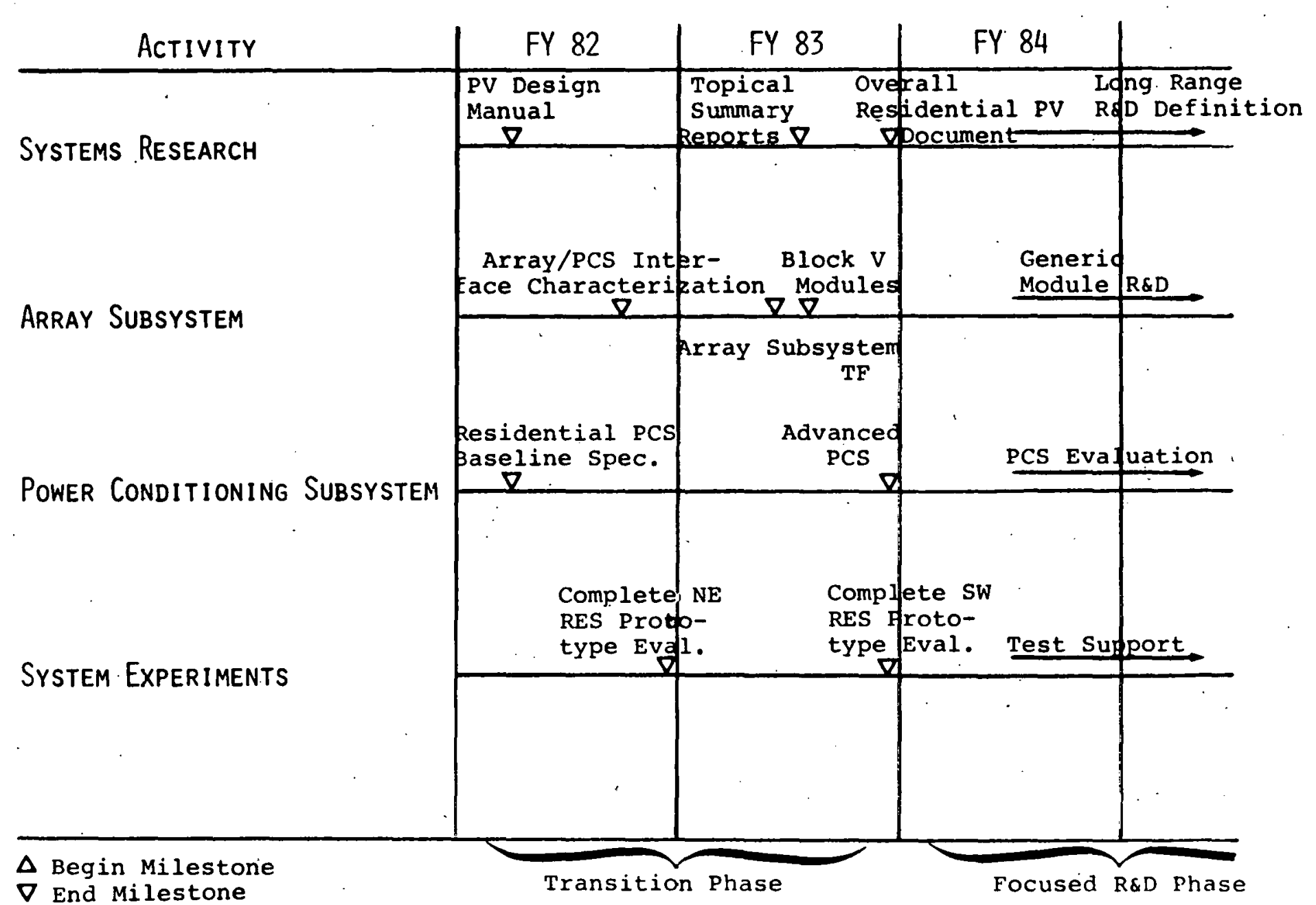




\section{OBJECTIVE}

To DEVELOP AND DOCUMENT A DETAILEd UNDERSTANDing OF RESIDENTIAL PHOTOVOLTAIC SYSTEM DESIGN AND PERFORMANCE TRADEOFFS, UTILITY INTERACTION, SAFETY, AND RELIABILITY,

\section{APPROACH}

- Develop design tools for Residential photovoltaic systems.

- Evaluate various photovoltaic system configurations and operational modes,

- Prepare topical summary reports on residential system research.

- Prepare overall photovoltaic residential summary document.

- SupPort CODES and STANDARDS Activity,

- Assist in defini-ion of the long-Range collector research and DeVElopMent EFFORT, 
OBJECTIVE

To develop and evaluate efficient, Reliable, and safe PV arRay subsystems for use in Residential systems. Tr.e arRay subsystem includes the PV module, arRay WIRING AND STRUCTURAL ELEMENTS.

MPPROACH

- Design and deVelop PV modules with residential specific features

- Pérform generic module R\&D

- Characterize array/PCS interface

- Evaluate array size/Voltage modularity

- Design, test and evaluate residential array concepts

- Support arRay safety and standards activities

- Characterize and evaluate arzay subsystem 
OBJective

To develop and eVAluate efficient, ReLiable, and safe power conditioning subSYSTEMS (PCS) FOR USE IN RESIDENTIAL PV SYSTEMS, THE POWER CONDITIONING SUBSYSTEM INCLUDES. DC/AC INVERSION, SYSTEM CONTROL, AND SYSTEM INTERFACES,

APPROACH

- Develop detailed residential pCS Lesign Documents

- Pefform PCS/Utilitir Interface Studies

- Develop improvements for state-of-the-art PCS hardware

- Conduct advanced technology development

- Plan and perform grid interface experiments

- Support PCS safety and standards activities

- Characterize and evaliate Power Conditioning Subsystems 
OBJECTIVE

EVALUATE RESIDENTIAL PV SYSTEM DESIgNS, INTERFACES AND COMPONENTS IN REALISTIC CONFIGURATIONS AND ENVIRONMENTS.

APPROACH

- Operate Residential Experiment Stations

- Design, construct, operate and eVAluate first generation prototype residential SYSTEMS

- Modify first generation prototypes to accommodate new haRdinare

- Build a flexible prototype test bed to support long range focused R\&D

- Design, construct, operate and evaluate selected initial System Evaluation EXPERIMENTS

- Provide limited support to selected PV Residences initiated outside the NATIONAL PV PROGRAM 


\author{
E. M. Mehalick \\ General Electric Company \\ Advanced Energy Programs Department \\ P. O. Box 527 \\ King of Prussia, PA 19406
}

The objective of the Detailed Residential Photovoltaic System Preferred Design Program is to develop regionally appropriate detailed photovoltaic system designs covering the major system options for the 1986 time frame in habitable residences. The initial selection of the system designs was based on previous work of all contractors in the PV residential area and consistent with the National PV Residential Program test plans. The designs are prepared for four regions of the country: the Southwest, the Northeast, the Southeast, and a temperate climate. A total of thirteen system configurations/regions were initially identified and six detailed designs have been developed. The designs consider various hardware options for the major subsystems. The output from the program includes for each design a separate report with a complete system description, including design requirements, functional characteristics and site characteristics; a block diagram; full scale electrical line drawing; thermal drawings; pictorial layouts; summary of performance characteristics and tradeoffs; and subsystem and component specifications. The reports have sufficient information to obtain detailed cost data from independent sources for installation of the proposed photovoltaic systems. The designs developed can be used as reference designs for typical equipment requirements, system performance estimates, installation details and system cost estimates.

The six designs completed are listed below:

1. An all PV system for a Southwest residence

2. A side-by-side PV/thermal system for a Northeast residence

3. A PV system with battery storage for the Southwest

4. An all PV system for a passive house design for the Northeast

5. An integral mounted array for a southeast residence

6. A standoff and integral mounted array for a temperate climate

The all PV system with feedback to the utility remains the simplest system to implement. The designs provide detailed drawings for installation of direct mounted modules (PV shingle and batten types), standoff mounted modules and integral mounted modules. Power conversion subsystem requirements have also been evaluated, relative to operating voltage ranges and losses associated with restricted voltage operation ranges, through system simulations. A correlation for estimating power losses for limiting system operation within specific voltage ranges has been developed. 
RESIDENT IAL REFERENCE

DESIGNS

E. M. MeHALICK

GENERAL ELECTRIC COMPANY

AdVAnced Energy PRograms Department.

KIng of PRUSSIA, PA.

เั

FEBRUARY 10, 1982 


\section{PROGRAM DESCR:PTION}

OBJECTIVE

- frepare detailed designs for site specific residential photovoltaic systems

SCOPE

- Cover four geographic areas (Southwest, Northeast, Southeast and Temperate (LIMATES)

- Consider major hardWare/subsystem options for 1986

- Level of detail sufficient for independent cost estimates

- NEW CONSTRUCTION HOUSES

OUTPUT

- DESign REPORT FOR EACH SYSTEM PROVIDING SYSTEM DESCRIPTION AND DRAWINGS 


\section{PRIMARY SYSTEM CONFIGURATIONS}
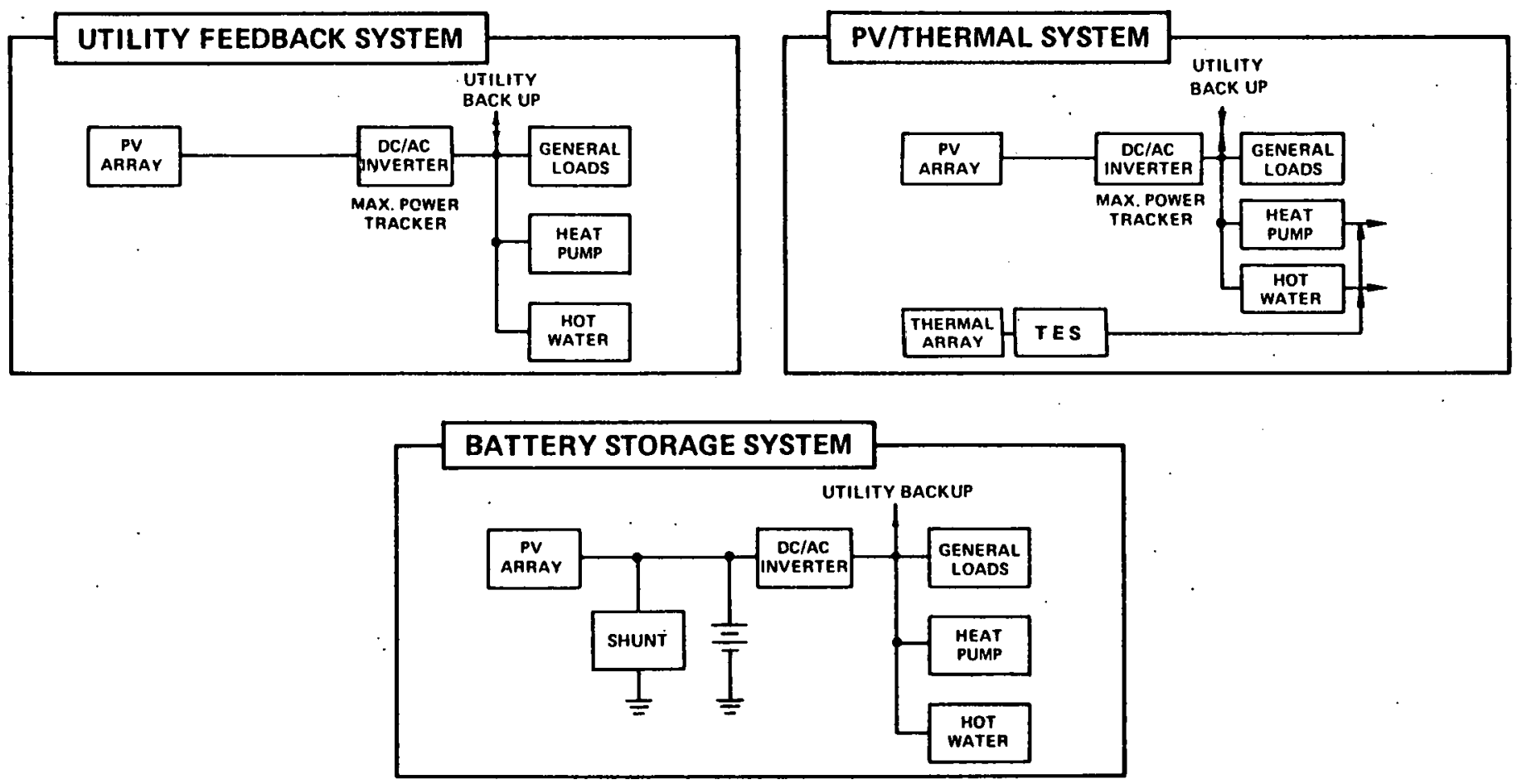


\section{DESIGN OPTIONS}
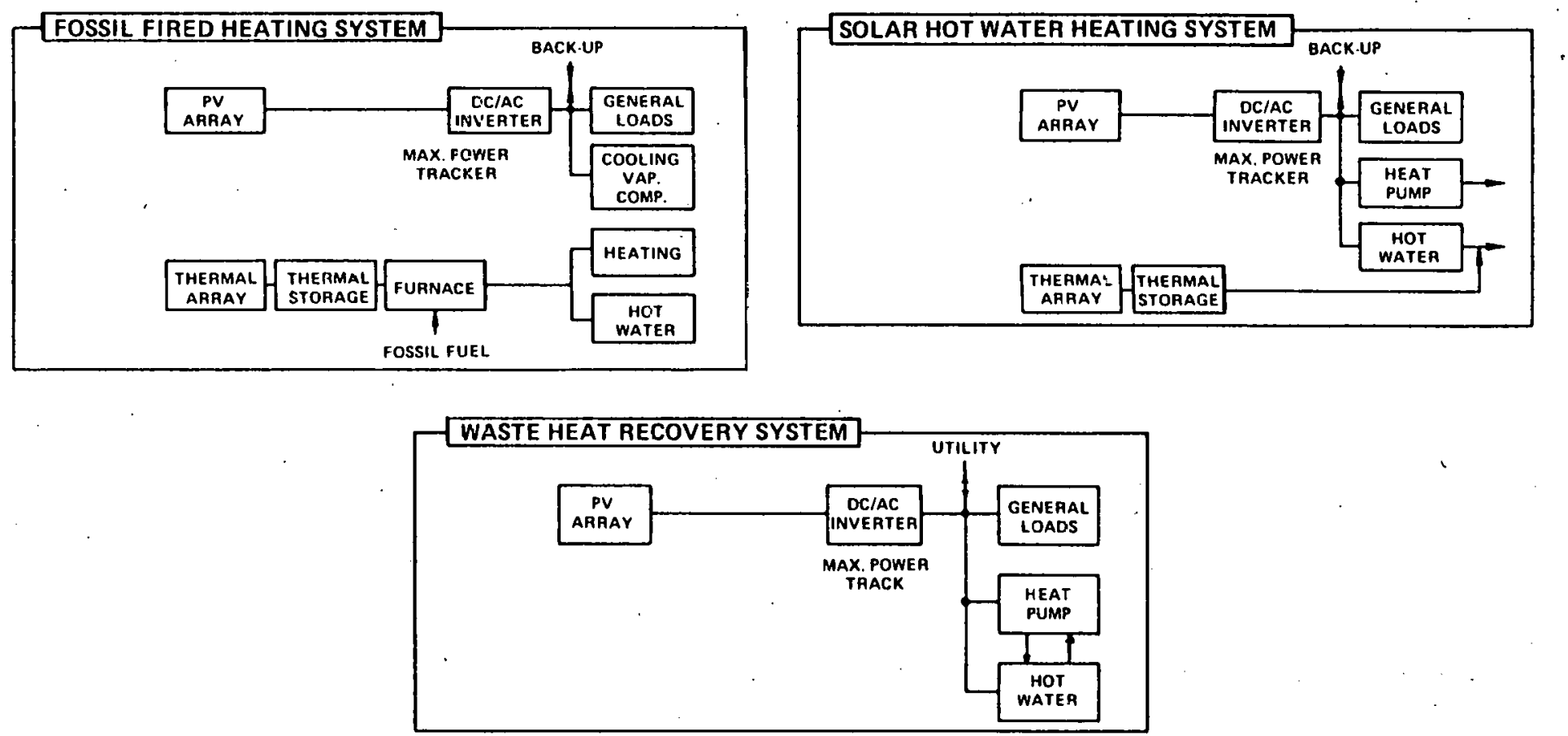
SELECTED SYSTEM DESIGNS

\begin{tabular}{|c|c|c|c|}
\hline SYSTEM CONFIGURATION & $\begin{array}{c}\text { MOUNTIING } \\
\text { CONFIGURATION }\end{array}$ & LOCATION & $\begin{array}{l}\text { RATIONALE FOR } \\
\text { DESIGN }\end{array}$ \\
\hline PV-ONLY WITH FEEDBACK & DIRECT & SOUTHWEST & SIMPLEST CONFIGURATION \\
\hline SIDE-BY-SIDE PV/T SOLAR ASSISTED HEAT PUMP & DIRECT & NORTHEAST & PV/THERMAL SYSTEM \\
\hline PV-ONLY WITH EATTERY STORAGE & STANDOFF & SOUTHWEST & BATTERY STORAGE \\
\hline PV-ONLY FOR A PASSIVE HOUSE CIESIGN & DIRECT & NORTHEAST & PASSIVE HOUSE DESIGN \\
\hline PV-ONLY WITH FEEDBACK & INTEGRAL & SOUTHEAST & $\begin{array}{l}\text { CLIMATE/MOUNTING TECH- } \\
\text { NIQUE }\end{array}$ \\
\hline PV-ONLY WITH FEEDBACK & $\begin{array}{l}\text { INTEGRAL AND } \\
\text { STANDOFF }\end{array}$ & TEMPERATE CLIMATE & NO SPACE CONDITIONING \\
\hline
\end{tabular}


ARRAY SUBSYSTEM

- 6E PV Shingle Direct Mount Module

- arco solar batten direct Mount Module

- Solarex Stand-off Mounted frame Module

- Side-By-Side Flat Plate Thermal Collectors

- INTEgRal Glass Laminated Modules

\section{STORAGE SUBSYSTEM}

- Feedback Energy to Utility

- Lead Acid Battery Storage

$$
\text { HVAC SUBSYSTEM }
$$

- Heat PuMP (hP)

- Fossil heating/Vapor Compression Cooling

- SOLAR ASSISTED HP

- SOLAR DOMESTIC HOt WATER (DHW)

- Space Conditioning heat Recovery for DHW

POWER PROCESSING AND CONTROL SUBSYSTEM

- WINDWORKS GEMINI INVERTER

- Abacus SUNVERTER 
- energy losses calculated FOR OPERATION WITH LIMITED VOLTAGE OPERATION.

- Minimum loss fixed Voltage POINT IDENTIFIED

- Correlations developed FOR CLIMATE CONDITIONS

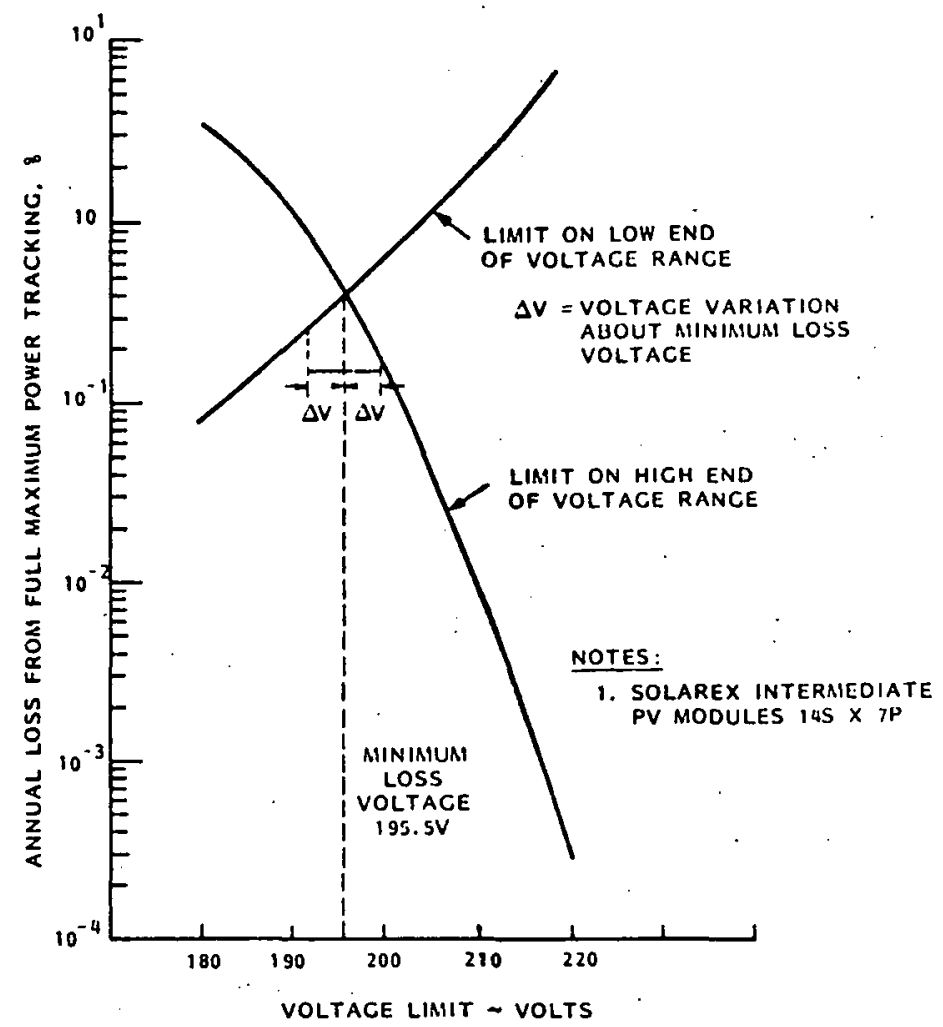




\section{Power Conversion Correlations}
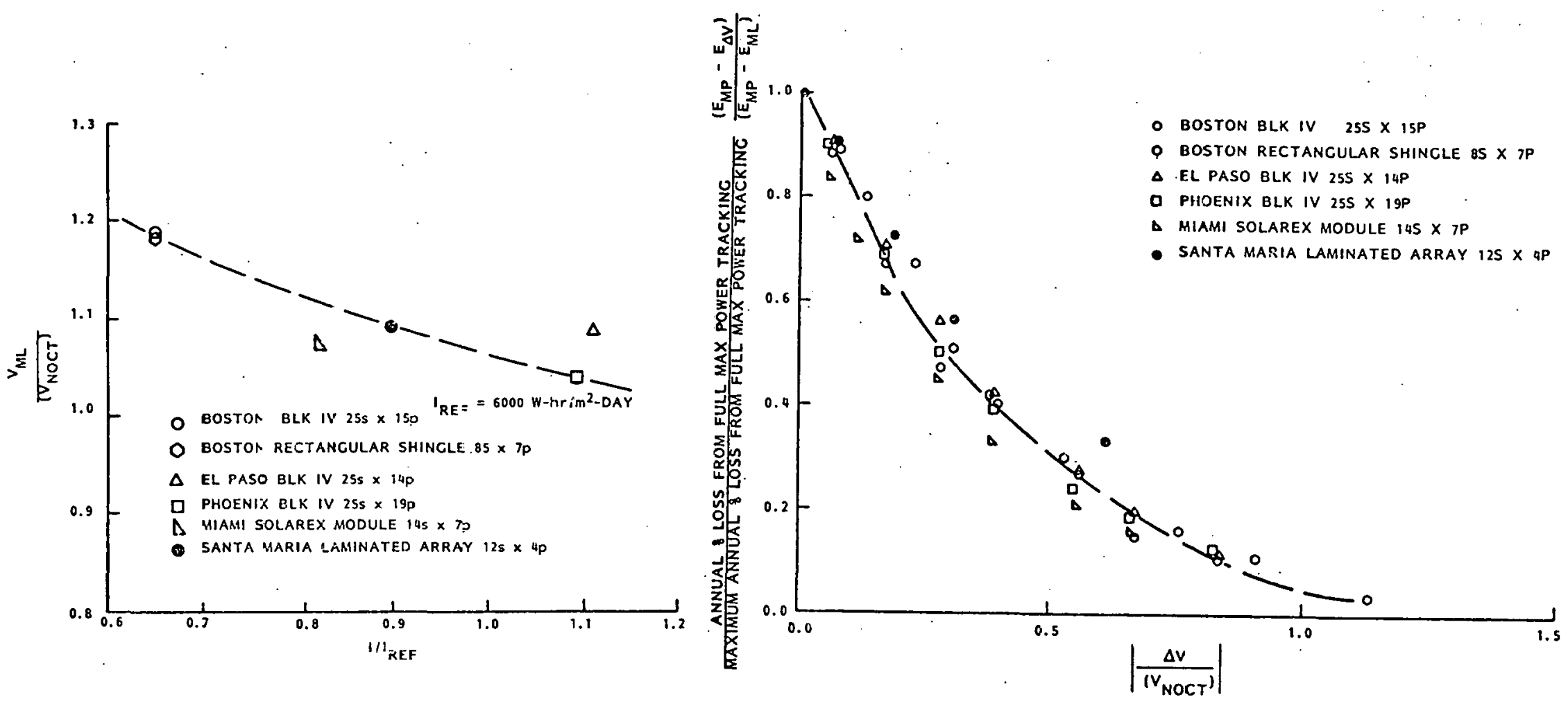
Array Open Circuit Voltage Variation

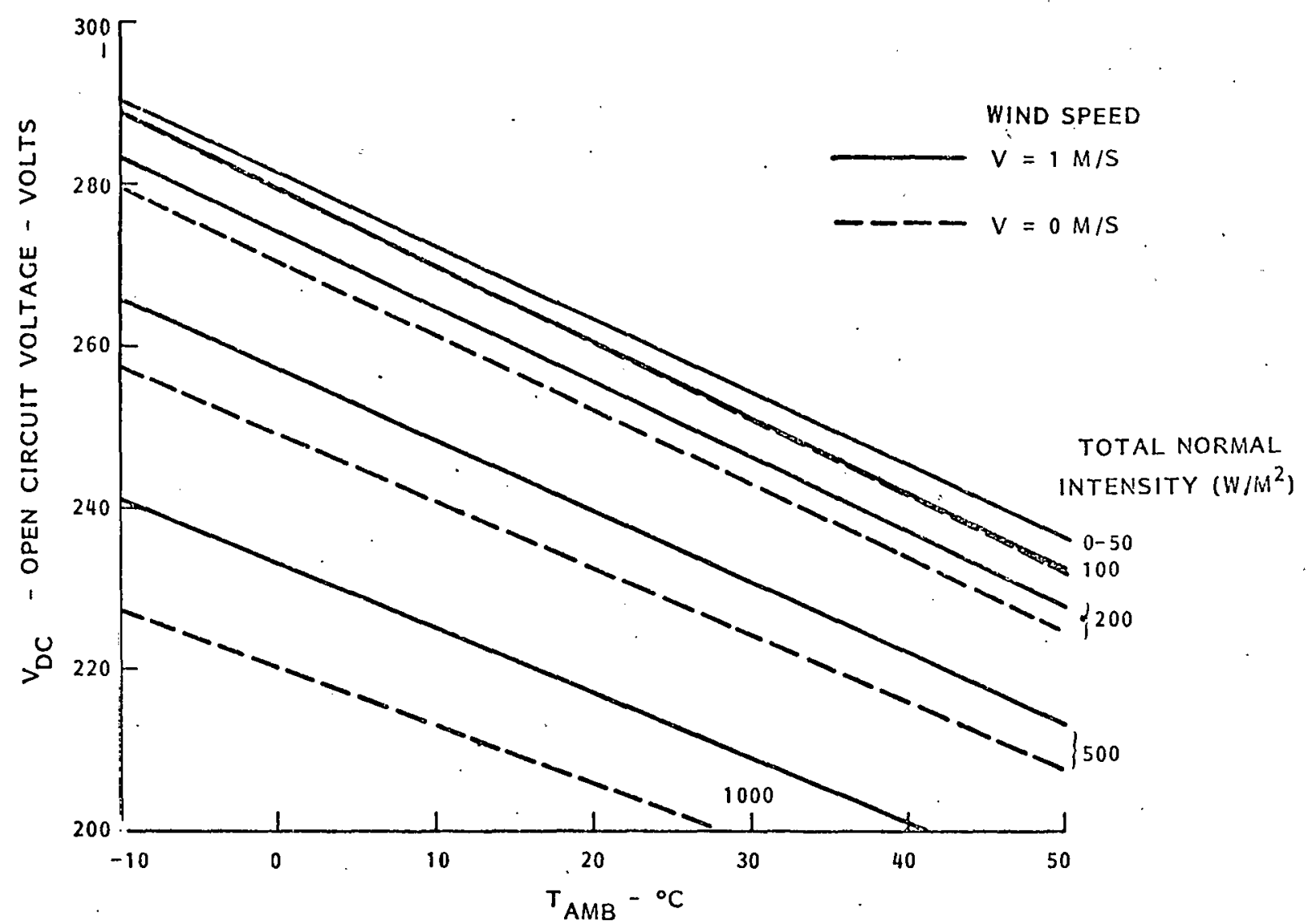




\section{SIJMMARY}

- Feedback System Simplest Configuration To Implement

- 4kl!p and $3 k M_{p}$ System Sizess Are Representative Of Residential Load Ranges

- Options to Reduce hot Hater loads Can Be Selected On Their Onn Economic Basis

- On-Site Battery Storage Adds System Complexity And Additional Design REQUIREMENTS

- Rojof Size Constraints impact Array Hiring Complexity

- Pjwer Conversion Subsystem Development Still Required 


\section{PHOTOVOLTAIC RESIDENTIAL RETROFITS}

by

Total Environmental Action, Inc.

7 Church $\mathrm{Hill}$

Harrisville, New Hampshire 03450

$\begin{array}{ll}\text { Contract No. } & 62-0229 \\ \text { Principal Investigator } & \text { D.E. Mahone } \\ & (603) 827-3374 \\ \text { Subcontractor: } & \text { Tri-Solar Corp. } \\ & \text { A.R. Millner } \\ & (617) 275-1200 \\ \text { Contract Amount: } & \$ 239,440 \\ \text { Contract Duration: } & \text { August, } 1980 . \\ & \text { January, } 1982\end{array}$

Project 0bjective: Orie of the largest potential markets for photovoltaic power systems is the retrofit market for residences. It is also one of the most difficult to characterize, because of the diversity of housing types, construction techniques, and site conditions. In addition, many PV system design and installation details for retrofit applications must be studied and solved. The goal of this study is to provide a comprehensive analysis of the potentials and problems of retrofitting PV power systems into the American housing stock.

Project Description: The first of three Tasks identifies characteristics of typical new and existing residences in the northeast, southeast and southwest regions of the United States. The study uses published data and reports, such as the housing census and energy reviews, to generate gross numbers of different housing types by region, age of building, construction, income group, etc. Summaries of other physical characteristics, such as building orientation, roof pitch, roofing material, and availability of utility spaces in buildings are compiled from existing studies and correlated (so far as possible) with the gross numbers. The result of Task 1 is an estimate of the total retrofit potential for PV systems in the U.S.

In Task 2, typical, specific housing designs are selected to represent new and existing single and multi-family residences in the three regions under study. The selection of these designs is influenced by information determined in Task 1. 
PV system components are selected for these buildings, including collector arrays, mounting hardware, power conditioning equipment, and system wiring. Components are selected and developed as generic designs from among available or nearly available (by 1986), state-of-the-art products.

In Task 3, system design and installation details are worked out for the typical building retrofits to provide detailed and accurate estimates of installation costs. Constraints imposed by building and electrical codes, construction practices, and levels of trade skills are acknowledged. Knowing the number of potential rooftops and the size, cost, and potential electrical output from residential PV installations, the market penetration potential is assessed, and the economic feasibility of residential. PV systems is analyzed. Costs over the life-cycle of the PV system are compared to the electrical costs without photovoltaic power. Using this method, a life-cycle cost ratio (LCCR) is calculated using the range of estimated system costs and the economic conditions from 10 Solar Economic Regions of the U.S. The assessment of power production potential uses roof area and weather data from these regions. As a final activity, potential barriers to residential PV retrofits and possible incentive programs for encouraging widespread acceptance of PV retrofits are discussed.

Current Status: Technical work on the project was completed in November, 1981. The draft final report is under review, and the final document will be published in early spring, 1982 .

Key Results: 1) There are approximately $60 \mathrm{million}$ residential structures in the U.S. Of these, $35 \%(21 \mathrm{million})$ are candidates for photovoltaic retrofits.

2) The national potential for cost effective residential PV retrofits is enormous: o There are 9.47 billion square feet $\left(879.8 \times 10^{6} \mathrm{~m}^{2}\right)$ of suitable rooftop.

- This area could accept $92.2 \times 10^{6}$ peak kilowatts of installed PV capacity.

- This could produce $142.5 \times 10^{6}$ megawat thours per year of electricity.

- This is equal to nearly $20 \%$ of the electricity used for residential purposes in 1980 .

3) The recommended residential module will'be approximately $4^{\prime} \times 6^{\prime}$, and will be entirely series wired internally to produce a nominal 100 volt output.

4) Residential retrofit arrays will be in the $4-8 \mathrm{~kW}_{\mathrm{p}}$ size range. Assuming the recommended 4' $\times 6^{\prime}$ module, each array will employ between 8-16 modules.

5) Total system costs will range from $\$ 2.00-\$ 2.81$ per peak watt.

6) Mounting systems for rooftop arrays must be very well designed to achieve market acceptance. Mounting system costs will account for $15 \%-35 \%$ of total system cost. 
7) Cost estimates for a $4 \mathrm{~kW}_{\mathrm{p}}$ retrofit array indicate a range of $\$ 8300$ - $\$ 11,300$ for total installed cost. The least expensive is a simple Standoff design, the most is a Rack mount.

8) The major present barrier to acceptance of photovoltaics for residential applications remains the high cost of systems. If the DOE 1986 Cost Goals are met, however, the systems will become cost effective (on a life-cycle cost basis) in many regions of the country. With.a $20 \%$ tax credit, they will be cost-effective everywhere but the Northwest. The high first cost. of the systems requires acceptable financing mechanisms for the homeowner. 
Buildings Suitable for PV Retrofit

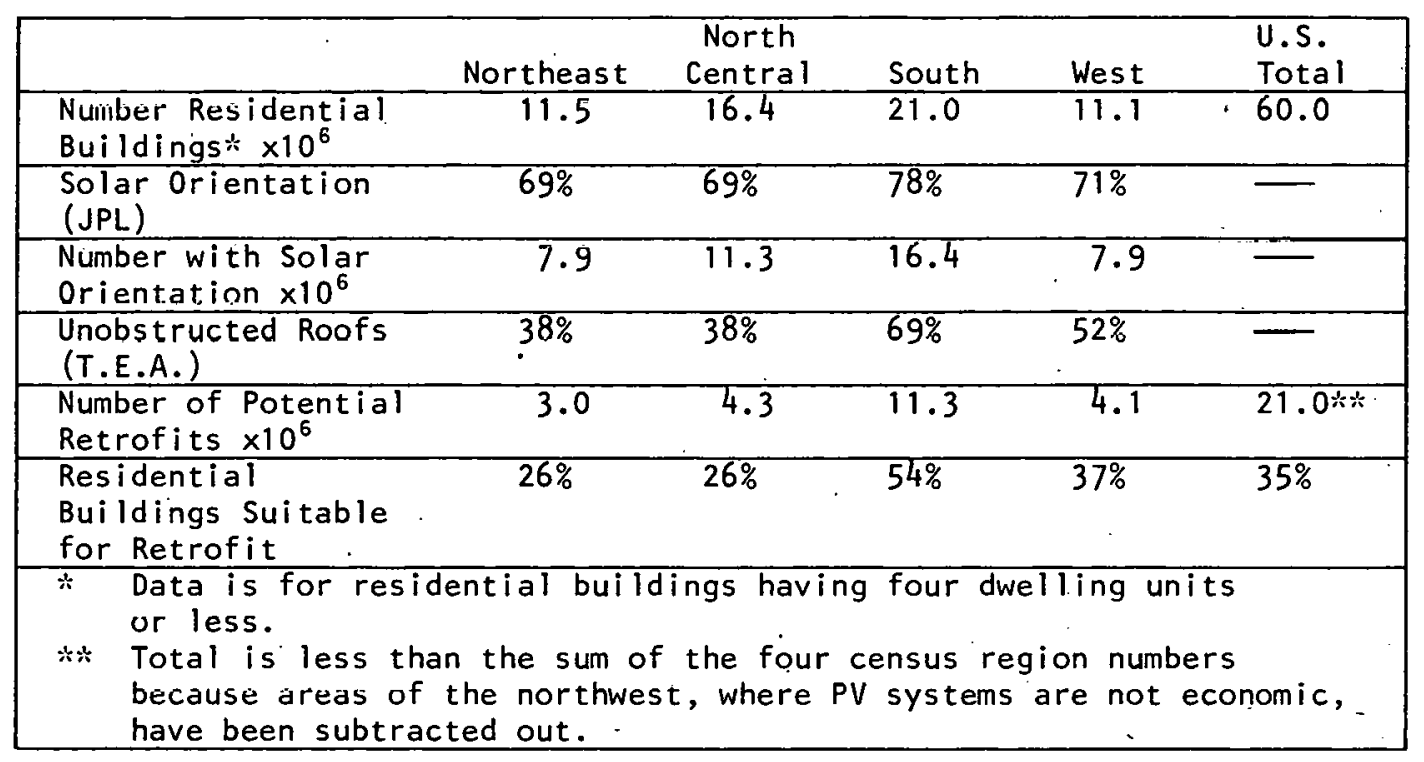

Usable Roof Area for Retrofit

\begin{tabular}{|c|c|c|c|c|c|}
\hline & Northeast & $\begin{array}{c}\text { North } \\
\text { Central }\end{array}$ & South & West & $\begin{array}{l}\text { U.S. } \\
\text { Total }\end{array}$ \\
\hline $\begin{array}{l}\text { Number of Potential } \\
\text { Retrofits } \times 10^{6}\end{array}$ & 3.0 & 4.3 & 11.3 & 4.1 & $21.0 *$ \\
\hline $\begin{array}{l}\text { Meall Sular Ruof } \\
\text { Area per House } \\
\mathrm{ft}^{2}\left(\mathrm{~m}^{2}\right) \times 10^{6}\end{array}$ & $\begin{array}{l}390 \\
(36.2)\end{array}$ & $\begin{array}{l}450 \\
(41.8)\end{array}$ & $\begin{array}{l}410 \\
(38.1)\end{array}$ & $\begin{array}{l}685 \\
(63.6)\end{array}$ & $\bar{Z}$ \\
\hline $\begin{array}{l}\text { Total Usable Roof } \\
\text { Area } \mathrm{ft}^{2}\left(\mathrm{~m}^{2}\right) \times 10^{6}\end{array}$ & $\begin{array}{l}1170 \\
(108.7)\end{array}$ & $\begin{array}{l}1935 \\
(179.8)\end{array}$ & $\begin{array}{l}4633 \\
(430.4)\end{array}$ & $\begin{array}{l}2808 \\
(260.9)\end{array}$ & $\begin{array}{l}9470 * \\
(879.8)\end{array}$ \\
\hline $\begin{array}{l}\text { Totals are less } \\
\text { because areas of } \\
\text { have been subtrac }\end{array}$ & $\begin{array}{l}\text { an lhe sum } \\
\text { he northwes } \\
\text { ed out. }\end{array}$ & $\begin{array}{l}f \text { the fou } \\
\text {, where } f\end{array}$ & $\begin{array}{l}\text { census r } \\
\text { systems. }\end{array}$ & $\begin{array}{l}\text { gion numb } \\
\text { re not ec }\end{array}$ & homic, \\
\hline
\end{tabular}


Power Production Potential From PV

\begin{tabular}{|c|c|c|c|c|c|}
\cline { 2 - 6 } \multicolumn{1}{c|}{} & $\begin{array}{c}\text { \# of } \\
\text { Buildings } \\
\times 10^{6}\end{array}$ & $\begin{array}{c}\text { Usable PV } \\
\text { Roof Area } \\
\mathrm{ft}^{2}\left(\mathrm{~m}^{2}\right) \times 10^{6}\end{array}$ & $\begin{array}{c}\mathrm{kWh} / \mathrm{yr} \\
\mathrm{per} W_{\mathrm{p}}\end{array}$ & $\begin{array}{c}\mathrm{kW} \\
\text { Peak } \\
\times 10^{6}\end{array}$ & $\begin{array}{c}\text { Total } \\
\mathrm{mWh} / \mathrm{yr} \\
\times 10^{6}\end{array}$ \\
\hline US TOTAL & 22.7 & $10,550(980.1)$ & - & 102.7 & 157.4 \\
\hline
\end{tabular}

\begin{tabular}{|l|r|rr|r|r|r|}
\hline $\begin{array}{l}\text { Economically } \\
\text { Feasible }\end{array}$ & & & & & \\
Lower NE-NYC & 1.64 & 640 & $(59.46)$ & $1.30 *$ & 6.2 & 8.1 \\
California & 2.32 & $1,610(149.57)$ & 1.90 & 15.7 & 29.8 \\
Southwest & .47 & $330(30.66)$ & 2.08 & 3.2 & 6.7 \\
Central & 1.31 & $570(52.95)$ & $1.56 *$ & 5.6 & 8.7 \\
Great Lakes & 4.42 & $1,900(176.51)$ & $1.41 *$ & 18.5 & 26.1 \\
Southern & 6.82 & $2,780(258.26)$ & 1.49 & 27.1 & 40.3 \\
Atlantic Bay & 1.45 & $590(54.18)$ & 1.41 & 5.7 & 8.1 \\
Mid South & 2.58 & $1,050(97.55)$ & 1.44 & 10.2 & 14.7 \\
\hline SUBTOTAL & 21.0 & $9,470(879.8)$ & & 92.2 & 142.5 \\
\hline
\end{tabular}

\begin{tabular}{|l|r|r|r|r|r|}
\hline Uneconomic & & & & & \\
North Central & 1.04 & $620(57.6)$ & $1.56 *$ & $6: 0$ & 9.4 \\
$\begin{array}{l}\text { Pacific } \\
\text { Northwest }\end{array}$ & .66 & $460(42.7)$ & 1.34 & 4.5 & 6.0 \\
\hline SUBTOTAL & 1.7 & $1,080(100.3)$ & - & 10.5 & 15.4 \\
\hline
\end{tabular}

* Takes into account snow cover and ground reflectance. 


\section{Projected Total System Costs}

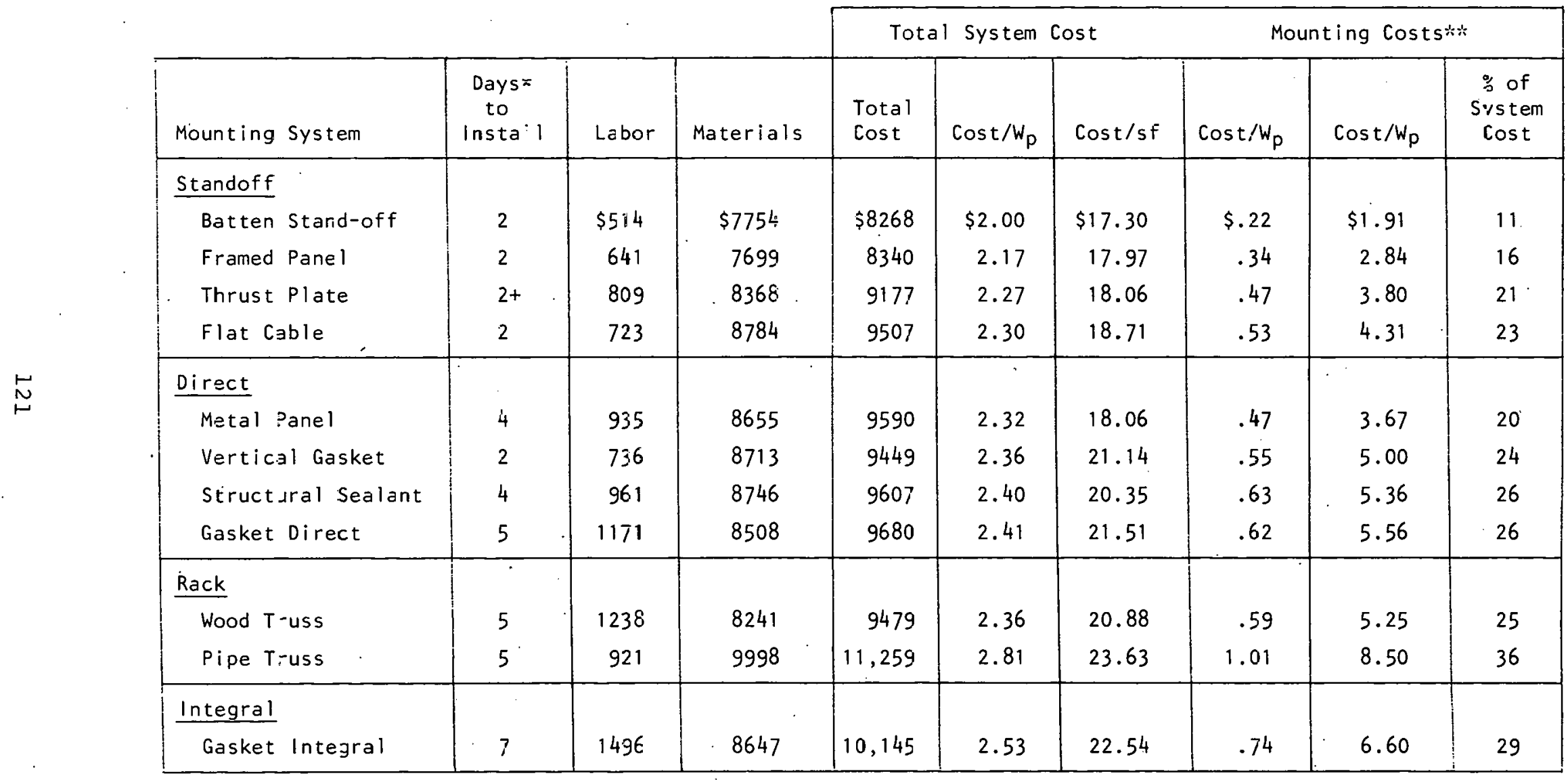

* two person crew

$\therefore$ total projected system costs minus total balance-of-system costs and module costs 
Figure 5.6

Vertical Gasket

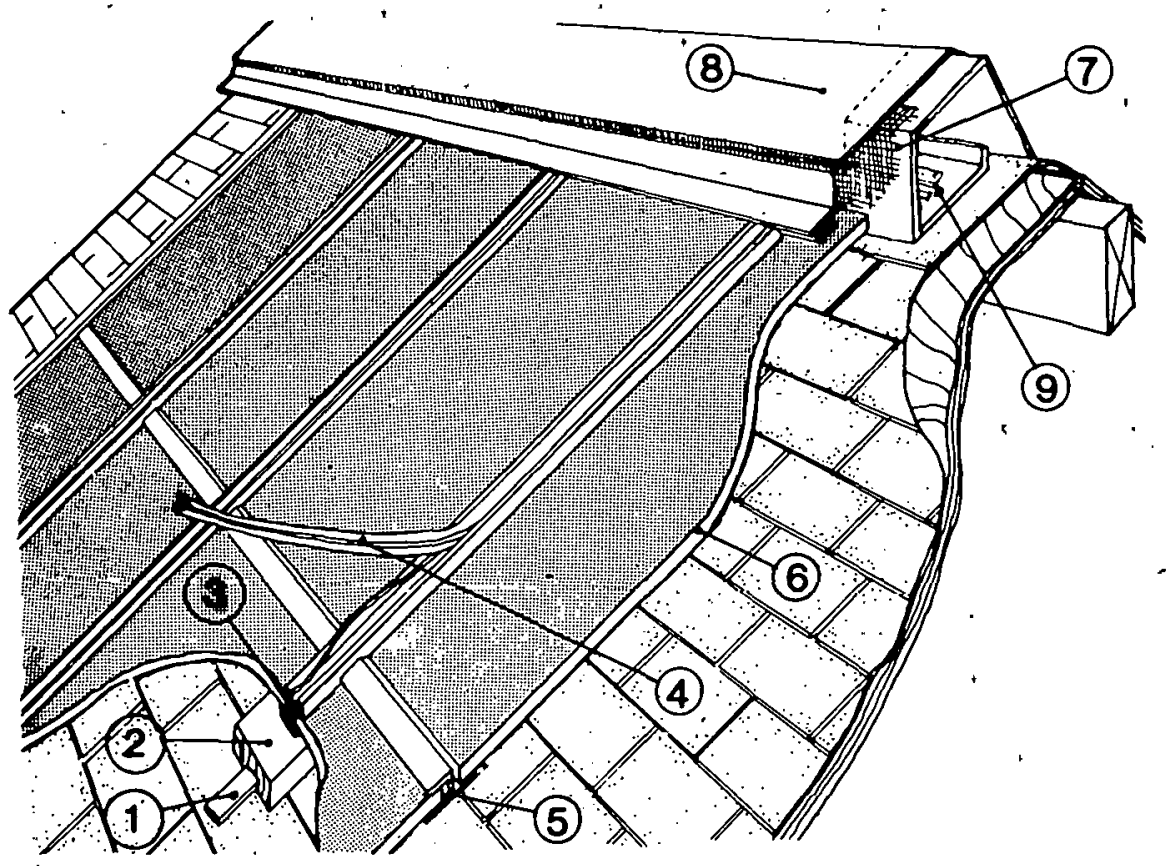

\section{VERTICAL GASKET}

\section{GLAZING TAPE}

2. BLOCKING

3. NEOPRENE GASKET.

4. LOCKING STRIP

5. H-CLIP

6. PV PANEL

7. CAP SUPPORTS

8. CAP FLASHING

9. WIRING 
DETAILED RESIDENTIAL ELECTRIC LOAD

DETERMINATION

by

The BDM Corporation

Albuquerque, NM 87106

\author{
Principal Investigator: George J. Collaros \\ (505) $848-5320$ \\ Contract No.: $\quad 62-3977$ \\ Contract Amount: $\quad \$ 255,000$ \\ Contract Duration: October 1980 to \\ - February 1982
}

\title{
ABSTRACT
}

The BDM Corporation (BDM) is conducting a direct measurement program of residential electric loads to develop a statistical model of residential electric load patterns which describes "instantaneous" load behavior from time-averaged data. The objective of the program is to determine the effect of transient loads on the net annual output of residential photovoltaic (PV) systems and to obtain residential load data at sample periods lower than 15 minutes to support different PV test programs. The work is being performed by BDM under contract with Sandia National Laboratories.

The Residential Load Project is divided into five phases directed at defining and acquiring instantaneous load data from residences and utilities and then using these data in PV system performance models. A comprehensive survey of utilities and related sources has shown that there is a lack of representative load data collected in intervals of less than 15 minutes. A direct measurement program has been initiated for three regions of the United States that will provide high resolution residential load data at intervals of 5 seconds. Powerline waveform quality measurements were taken on twn residences and on a selection of inverters to determine the current and voltage waveform in both the time domain and frequency domain. A preliminary statistica model has been developed which can use time-averaged data typically collected by utilities to generate a set of higher frequency and amplitude. instantaneous-like electrical load transients. 


\title{
TASK DESCRIPTION
}

\author{
PROGRAM OBJECTIVES: \\ PRODUCE DETAILED DETERMINATION OF RESIDENTIAL \\ ELECTRICAL LOAD PATTERNS FOR TYPICAL RESIDENCES IN \\ THREE REGIONS OF THE UNITED STATES.
}

PROGRAM TASKS:

I - A COMPREHENSIVE SURVEY OF UTILITIES AND RELATED SOUCES TO DETERMINE THE AVAILABILITY OF REAL-TIME INSTANTANEOUS AND TIME-AVERAGED LOAD DATA FOR TYPICAL RESIDENCES

II - A DIRECT MEASUREMENT PROGRAM IN THE THREE REGIONS TO SUPPLEMENT DATA GAPS

III - THE DEVELOPMENT OF A STATISTICAL LOAD MODEL TO PREDICT THE FREQUENCY AND INTENSITY OF INSTANTANEOUS SPIKES

IV - THE VERIFICATION OF THE MODEL AND THE CALCULATIONS OF THE ANNUAL LOAD DEMAND MET BY PV SYSTEM 


\section{DETAILED RESIDENTIAL LOAD DATA ACQUISITION AND LOAD MONITORING SYSTEM}

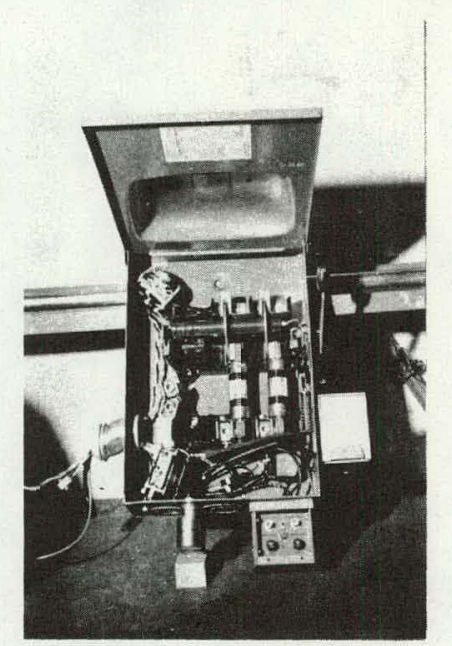

SWITCH BOX AND POWER SENSORS ICURRENT

TRANSFORMERS)

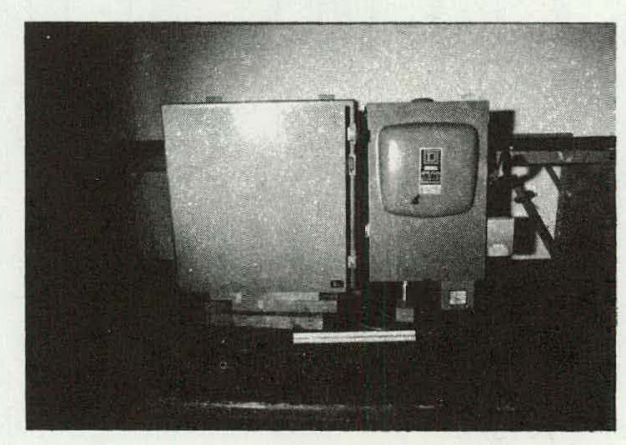

PACKAGED ENCLOSURES MOUNTED AT RESIDENCES

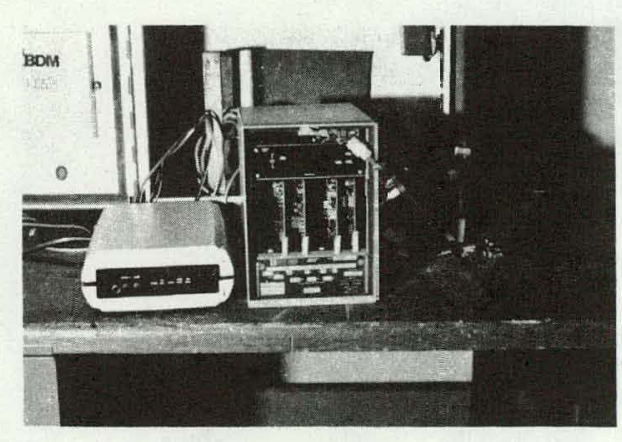

JEM- 1 METER \& MODEM

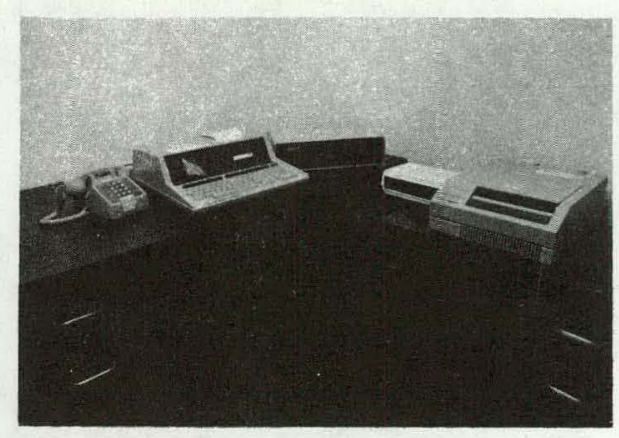

HP 85 DATA ACQUISITION SYSTEM (a) BDM IN ABO

BDM/A-81-060-BR-R1 
RESIDENTIAL APPLICANCE CHARACTERIZATION

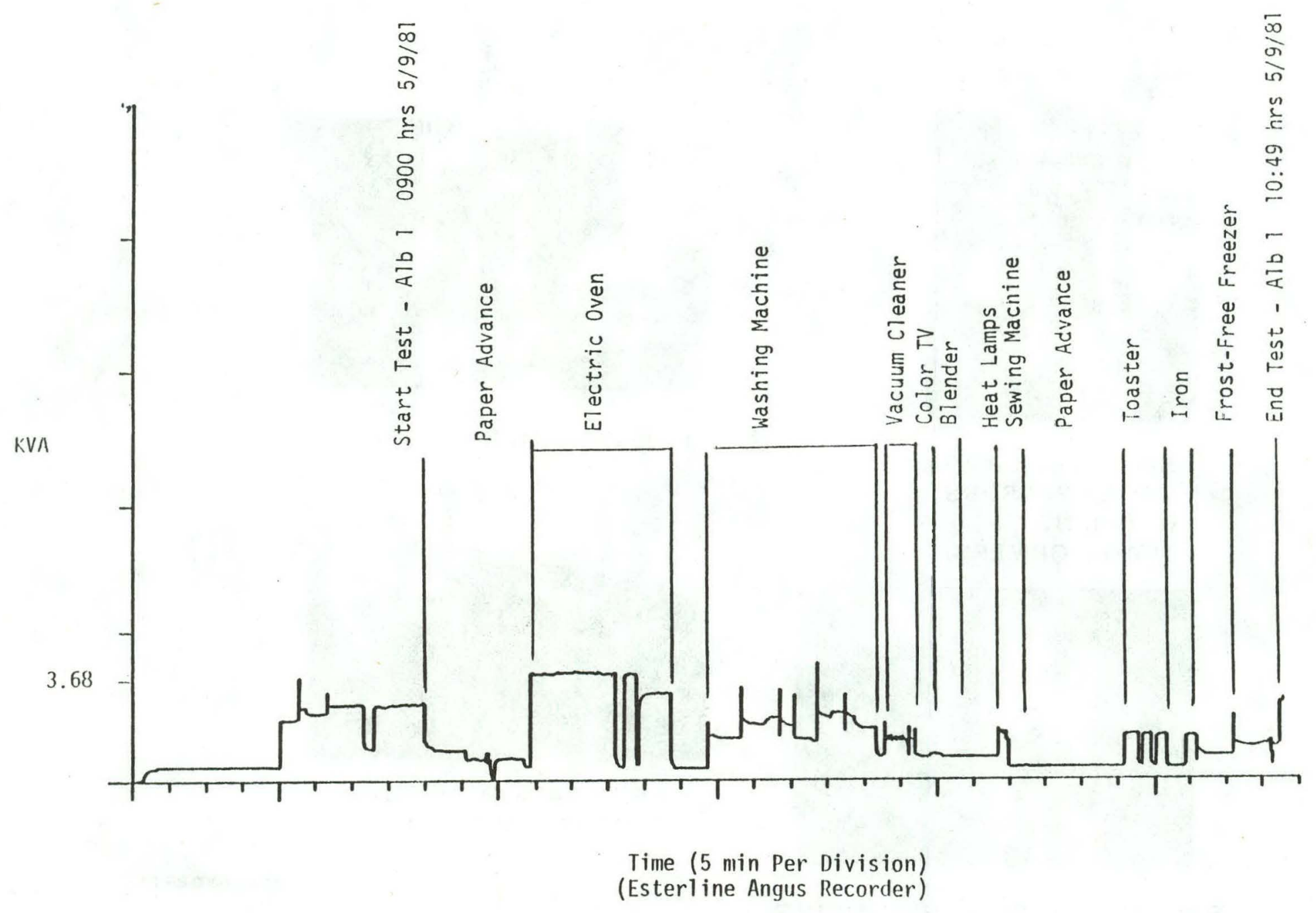




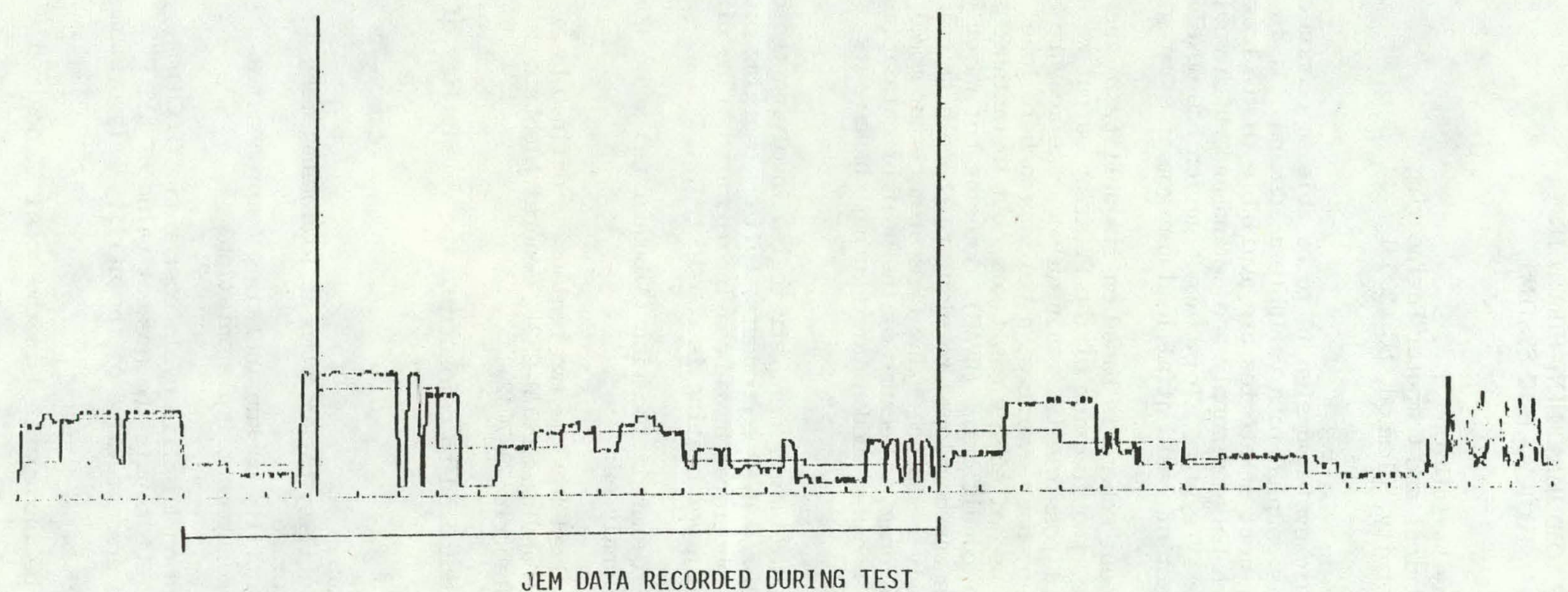




\title{
INVESTIGATION OF LOAD MANAGEMENT STRATEGIES \\ FOR RESIDENTIAL PHOTOVOLTAIC SYSTEMS
}

\author{
Jay W. Lathrop \\ Department of Electrical and Computer Engineering \\ Clemson University, Clemson, SC 29631
}

\begin{abstract}
A challenge of residential photovoltaic system design is to be able to economically evaluate a variable de supply which is coupled to a variable ac demand. It is inherently felt that certain load management strategies are available to the home owner which will permit a closer match between supply and demand and which would improve the cost effectiveness of the PV system. This investigation has developed a methodology for evaluating the effect of residential load management strategies.
\end{abstract}

The effectiveness of any load management scheme is based on its ability to increase the system's direct use fraction, i.e. the fraction of the PV array output which is in-phase with demand. Since it is not possible to obtain an accurate measure of this parameter considering only hour-by-hour averages, a new approach to load modelling based on the instantaneous use of energy was taken. An instantaneous model for the heating-ventilating-air conditioning (HVAC), domestic hot water (DHW), and diversified (DIV) load components was developed to simulate the electrical demand of an all-electric single family residence. The PV system output model of necessity must still involve hourly averaging because of the weather data format, but this is not a serious limitation because sudden large output changes are relatively rare.

The possibility of non-participatory load management strategies involving the dryer operation, thermal storage in the DHW and HVAC components, battery charging procedures, and the minimum inverter output level have been incorporated. The direct use of dc power for water heating and dryer heating is considered.

Economic analyses were performed for a sunbelt location (Albuquerque) and a nonsunbelt location (Boston). In these analyses:

1. The array and battery were sized for the two regions as defined by previous PV system studies (Sandia: SAND79-2331, Gcneral Electric: SAND78-7029, Westinghouse Electric:78-7042).

2. Four system scenarios were compared to demonstrate the versatility of the approach:

a) utility only

b) array with utility backup

c) array and battery with utility backup without load management of dryer and thermal storage

d) array and battery with utility backup including comprehensive non-participatory load management implomentation.

3. System comparisons are based on the life cycle cost ratio (LOCR) as described in SAND79-2331. LCCR equals the present value of all PV system costs divided by the present value of the utility-only system costs.

Participating load management could be incorporated in the model if desired.

The draft final report for this study has been completed and is being reviewed. 


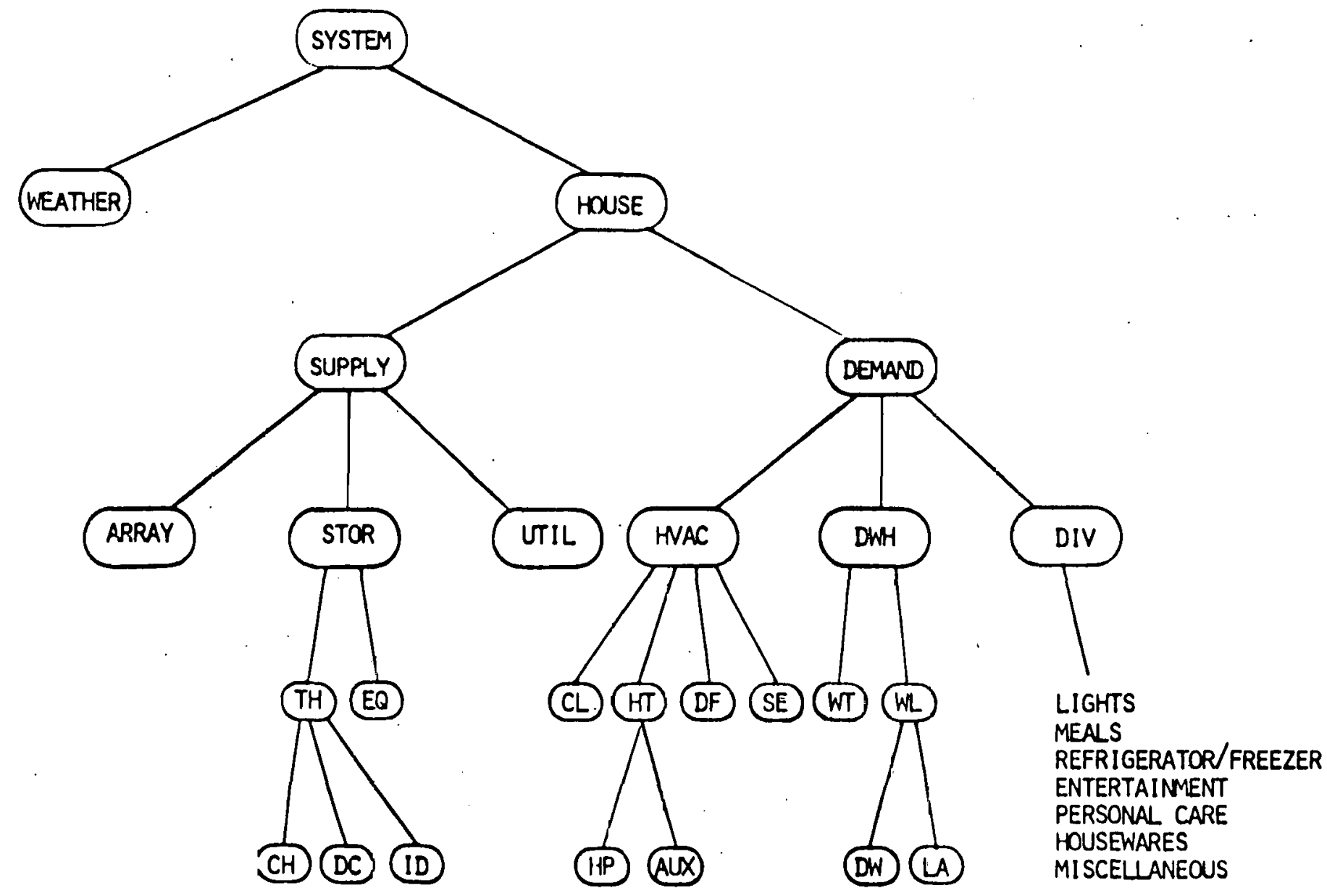

PHOTONOLTAIC MODEL HIERARCHICAL STRUCTURE 
ENERGY PER DAY IN EXCESS OF DEMAND WITH A 5000 WATT ARRAY

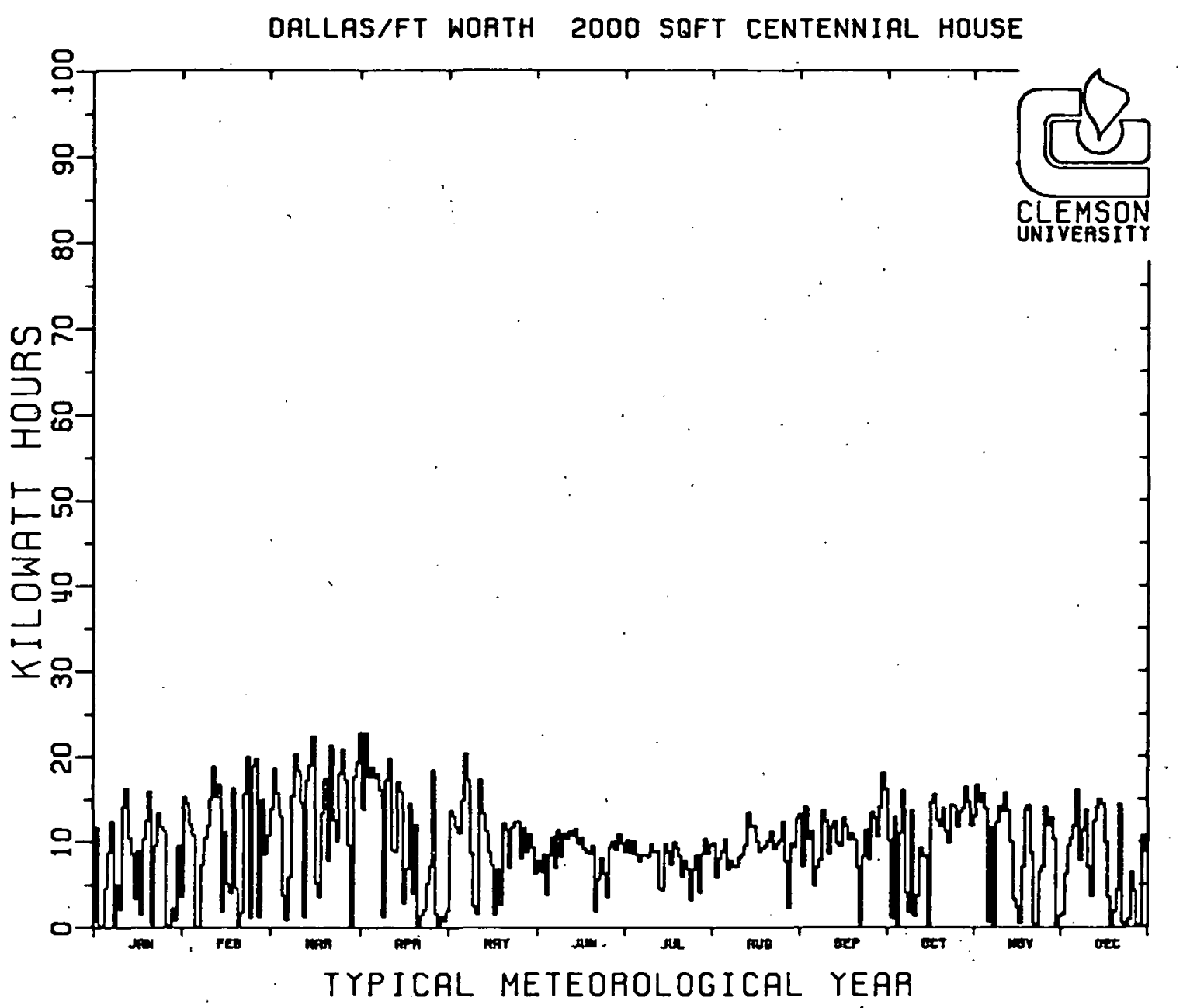


ENERGY PER DAY IN EXCESS OF DEMAND WITH A 5000 WATT ARRAY DALLAS/FT WORTH 2000 SOFT CENTENNIAL HOUSE

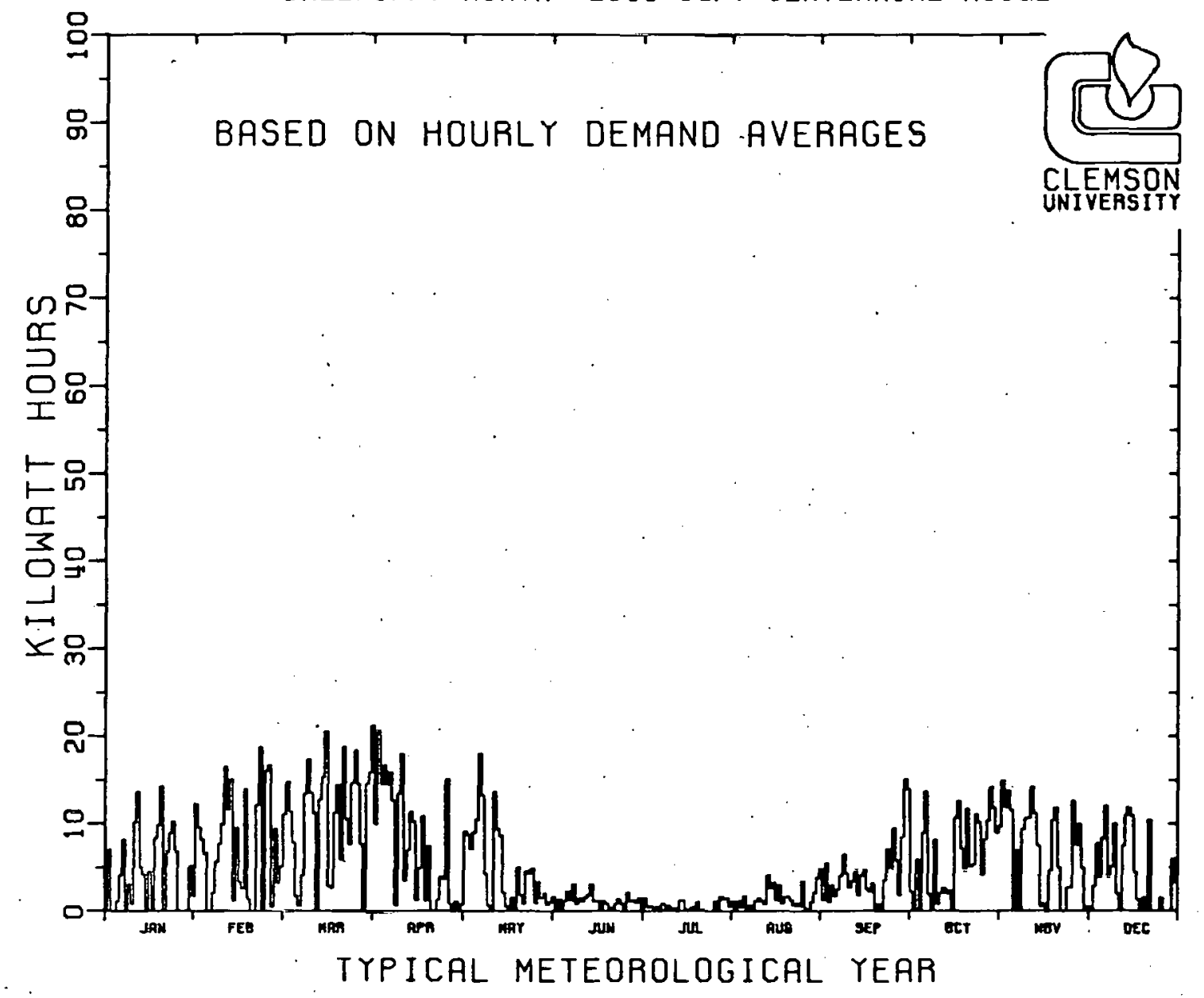




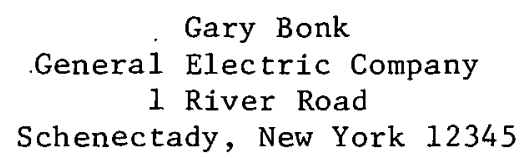

This study addressed the economic decision issues facing potential non-utility owners of Photovoltaic power systems.

Particular PV systems were modeled, as a representation of today's practical and available hardware, and assigned to residential, commercial and industrial applications.

The future value of PV energy production was then reflected through displacement calculations using a nine region U.S. electric power system model. Both Life Cycle and Payback Period economic methods were used in the study.

Reference case results showed that displarement of utility load leads to higher PV value potential in regions with heavy oil usage, low load.growth rate, and high insolation level, such as WSCC south.

Various energy supply scenarios were evaluated as change cases, using the same U.S. regional models. The most important effects resulted from changes in assumptions concerning oil price (levels and escalation rates) and in oil usage patterns.

A key factor in the user-oriented economic calculations is the necessity for flowthruugh of uti.1.ty "avoided costs" in order to show economic viability for user-owned PV systems. 


\section{ENERGY SCENARII) EFFECTS}

\section{EMERGY SCENARIO EFFECTS}

Photovol taic Energy Scenario

study

Contract $13-9482$

\section{Study 0bjectives}

February 10, $\mathbf{i} 982$

Gary Bonk

General Electric Company

Schenectody, New York 
Accompl ishments:

\section{Study Work}

I Characterize PV Systems

II Define Utility Scenarios

III Relate-:

Utility PV Savings

PV User Costs

- PV System Selection

- PV-Integrated OGP Load Model

- USA Model on Regional Basis

- Alternate Scenar10 OGP Runs

- Utility Rate Structure Model

- User Economic Analysis

- Graphic Communication Device 
ENERGY SCENARIO EFFECTS

\section{System Selection}

- Identify Possibilities

w

- Select 4 That Meet Criteria

- Translate Parameters
ENERGY SCENARIO EFFECTS

PV System Performance

\begin{tabular}{|c|c|c|c|c|}
\hline \multirow[b]{2}{*}{$\begin{array}{l}\text { PHOTOVOLIAIC } \\
\text { SYSTEM TYPE }\end{array}$} & \multirow[b]{2}{*}{ RATING } & \multicolumn{3}{|c|}{ ALANUAL CAPACITY FACTOR } \\
\hline & & SEATtLE & BOSTON & SANTA MARIA \\
\hline DIRECT MOUNT & $5.87 \mathrm{kH}$ & 15.68 & $17.6 x$ & $25.6 x^{\circ}$ \\
\hline FLAT PLATE & $91.5 \mathrm{KH}$ & 14.28 & $15.7 x$ & $22.3 x$ \\
\hline LINE FOCUS & $128 \mathrm{KH}$ & 11.98 & 14.08 & 23.28 \\
\hline POIHT FOCUS & $125 \mathrm{KM}$ & $13.2 x$ & $15.5 x$ & 25.48 \\
\hline
\end{tabular}

$-5-$ 


\section{ENERGY SCENARIO EFFECTS}

\section{ENERGY SCENARIO EFFECTS}

o Utility Modeling

- Energy ŝcenarios

OGP Results

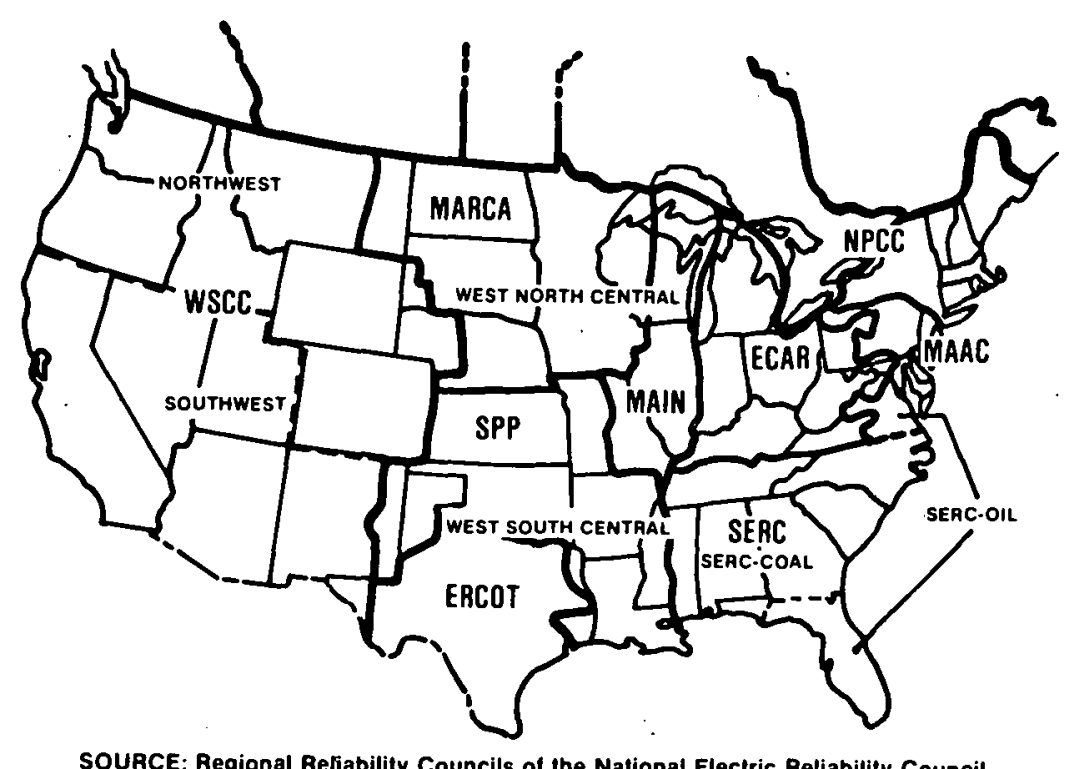

REG IONAL UTILITY MODEL 
ENERGY SCENARIO EFFECTS

VARIABLE INPUT
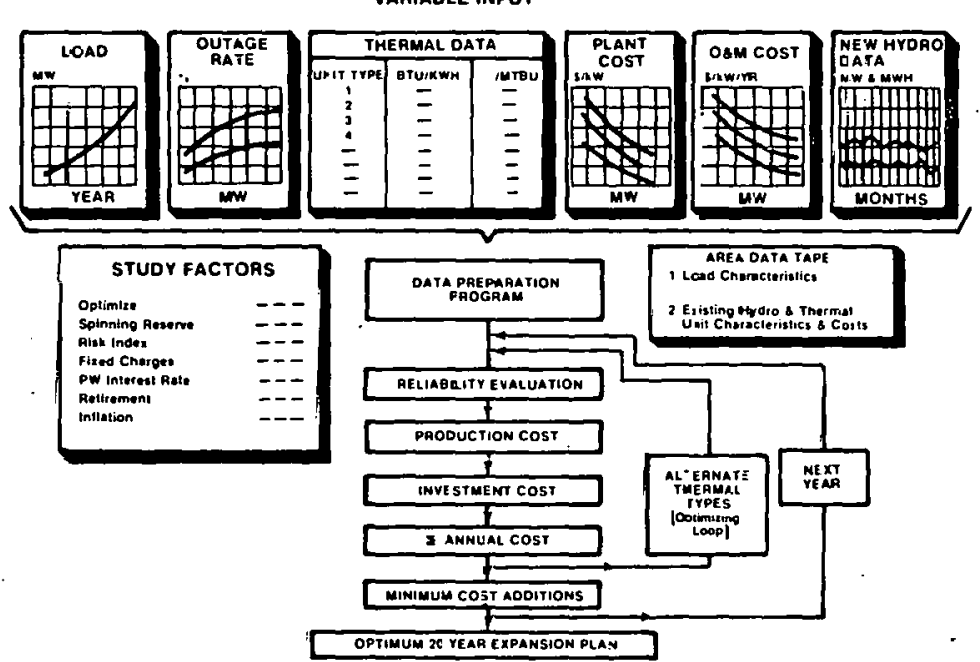

ENERGY SCENAFIO EFFECTS

Data_Assumptions

- Load Growth

- New Unit Types Available

- Fuel Costs

- Plant Costs

0 Inflation Rates

- Outage Fates

o Thermal Charøcteristics

OPTIMIZED GENERATION PLANNINE PROGRAM 
REFERENCE SCENARIO GENERATION MIX (\$ of Total MW)

\begin{tabular}{|c|c|c|c|c|c|c|c|c|c|}
\hline & $\underline{\text { Year }}$ & Region & Nuclear & $\underline{\text { Coal }}$ & $\begin{array}{c}011 \\
8 \text { cas } \\
\end{array}$ & $\begin{array}{l}\text { Hodro } \\
\text { \& PSH }\end{array}$ & GI & $\underline{C C}$ & 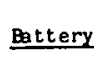 \\
\hline & \multirow[t]{9}{*}{1986} & ECAR & 11.9 & 75.9 & 4.8 & 3.2 & 3.7 & 0.5 & 0.0 \\
\hline & & ERCOT \& SPP & 11.5 & 34.9 & 46.6 & 2.3 & 3.7 & 1.0 & 0.0 \\
\hline & & MAAC & 26.1 & 29.3 & 24.3 & 4.2 & 15.0 & 1.1 & 0.0 \\
\hline & & MAIN \& MARCA & 22.9 & 59.0 & 5.8 & 4.1 & 8.0 & 0.2 & 0.0 \\
\hline & & NPCC & 24.4 & 10.0 & 42.1 & 14.0 & 8.7 & 0.8 & 0.0 \\
\hline & & SEFC-COAL & 32.4 & 50.5 & 1.2 & 11.7 & 4.1 & 0.0 & 0.0 \\
\hline & & SERC_OIL & 20.4 & 23.2 & 36.5 & 5.5 & 12.3 & 2.0 & 0.0 \\
\hline \multirow{11}{*}{$\underset{\omega}{\omega}$} & & Wsec-NW & 12.2 & 29.0 & 1.1 & 54.7 & 2.1 & 0.9 & 0.0 \\
\hline & & WSCC-SW & 13.6 & 21.4 & 35.8 & 17.2 & 5.6 & 6.3 & 0.0 \\
\hline & \multirow[t]{9}{*}{2001} & ECAR & 40.6 & 49.3 & 2.8 & 2.3 & 2.3 & 0.3 & 2.4 \\
\hline & & ERCOT \& SPP & 48.1 & $21 .:$ & 21.5 & 1.2 & 1.8 & 0.5 & 5.8 \\
\hline & & MAAC & 39.8 & 24.9 & 16.4 & 3.2 & 11.6 & 0.8 & 3.3 \\
\hline & & MAIN\& MARCA & 56.2 & 29.1 & 2.4 & 2.1 & 4.0 & 2.8 & 3.4 \\
\hline & & $\mathrm{NPCC}$ & 48.8 & 6.9 & 27.6 & 10.4 & 5.8 & 0.5 & 0.0 \\
\hline & & SERC-COAL & 56.8 & 28.7 & 0.6 & 6.4 & 2.3 & 0.0 & 5.2 \\
\hline & & SERC-OIL & 53.3 & 18.2 & 27.5 & 2.7 & 6.0 & 1.0 & 1.3 \\
\hline & & WSCC-Nw & 38.8 & 18.3 & 0.6 & 30.2 & 7.7 & 1.2 & 3.2 \\
\hline & & WSCC_SW & 43.7 & 17.8 & 20.4 & 10.4 & 3.3 & 4.4 & 0.0 \\
\hline
\end{tabular}

Potential Supply Scenarios

Scenario Nimber

Description MAIN \&

SERC- SERC- SPP \& WSCC- WSCCReference - No PV ECAR MAAC MARCA NPCC COAL OIL ERCOT South North Reference - $5 \% \mathrm{PV}$ No New Nuclear Nuclear Backout Wind Energy - 5\% High Plant Costs High Reserve Margin Low Load Growth Oil Backout High Fuel costs Moderate Oil Escal. PV Penetration

$\begin{array}{lllllllll}\mathrm{x} & \mathrm{x} & \mathrm{x} & \mathrm{x} & \mathrm{x} & \mathrm{x} & \mathrm{x} & \mathrm{x} & \mathrm{x} \\ \mathrm{x} & \mathrm{x} & \mathrm{x} & \mathrm{x} & \mathrm{x} & \mathrm{x} & \mathrm{x} & \mathrm{x} & \mathrm{x} \\ & & & \mathrm{x} & \mathrm{x} & & \mathrm{x} & \mathrm{x} & \\ & & & \mathrm{x} & \mathrm{x} & & \mathrm{x} & \mathrm{x} & \\ & & & \mathrm{x} & & & \mathrm{x} & \mathrm{x} & \\ \mathrm{x} & & & & \mathrm{x} & \mathrm{x} & \mathrm{x} & \mathrm{x} & \\ & & & \mathrm{x} & \mathrm{x} & & & \mathrm{x} & \\ \mathrm{x} & \mathrm{x} & & \mathrm{x} & & & \mathrm{x} & \mathrm{x} & \\ & \mathrm{x} & & \mathrm{x} & & \mathrm{x} & & \mathrm{x} & \\ \mathrm{x} & & & \mathrm{x} & & \mathrm{x} & & \mathrm{x} & \\ & \mathrm{x} & & \mathrm{x} & & & \mathrm{x} & \mathrm{x} & \\ & & & \mathrm{x} & \cdot & & & \mathrm{x}\end{array}$

REFERENCE SCENARIO MIX OF OGP - SELECTED ADDITIONS

\begin{tabular}{|c|c|c|c|c|c|}
\hline Regions & Muclear & Coal & $\underline{C T}$ & $\mathrm{cc}$ & Batterx \\
\hline ECAR & 93.3 & 0.0 & 0.0 & 0.0 & 6.7 \\
\hline ERCOT \& SPP & 86.6 & 1.6 & 0.0 & 0.0 & 11.3 \\
\hline MAAC & B4. 4 & 0.0 & 0.0 & 0.0 & 15.5 \\
\hline MAIN $\&$ MARCA & 87.6. & 0.0 & 0.0 & 5.5 & 6.9 \\
\hline $\mathrm{NPCC}$ & $100.0^{\circ}$ & 0.0 & 0.0 & 0.0 & 0.0 \\
\hline SERC-COAL & 87.6 & $0.0^{\circ}$ & 0.0 & 0.0 & 12.4 \\
\hline SERC-OIL & 92.5 & 4.7 & 0.0 & 0.0 & 2.8 \\
\hline WSCC-Nw & 72.3 & 2.2 & 15.8 & 2.8 & 7.9 \\
\hline WSCC_SW & 96.8 & 3.2 & 0.0 & 0.0 & 0.0 \\
\hline
\end{tabular}


ENERGY SCENARIO EFFECTS

ENERGY SCENARIO EFFECTS

PV Load Model ing

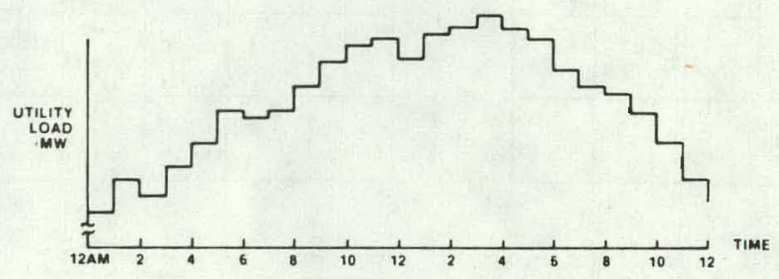

OGP Modeling Issues

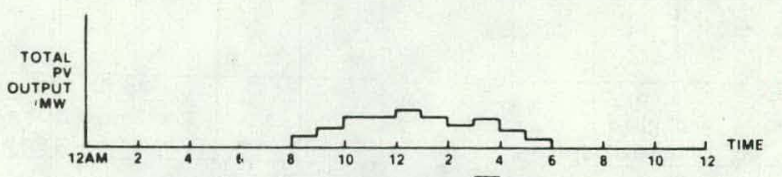

o Capacity Displacement

o Maintenance Shifting

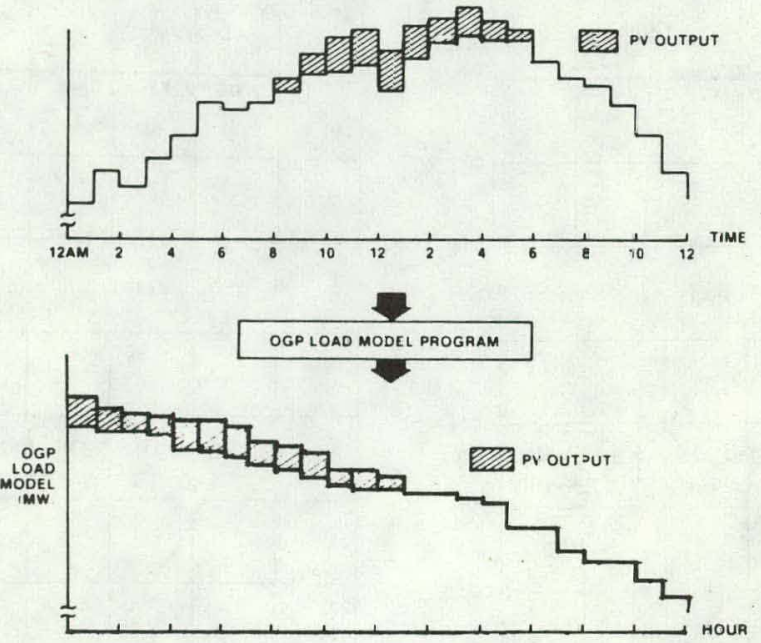




\section{ENERGY SCENARIO EFFECTS}
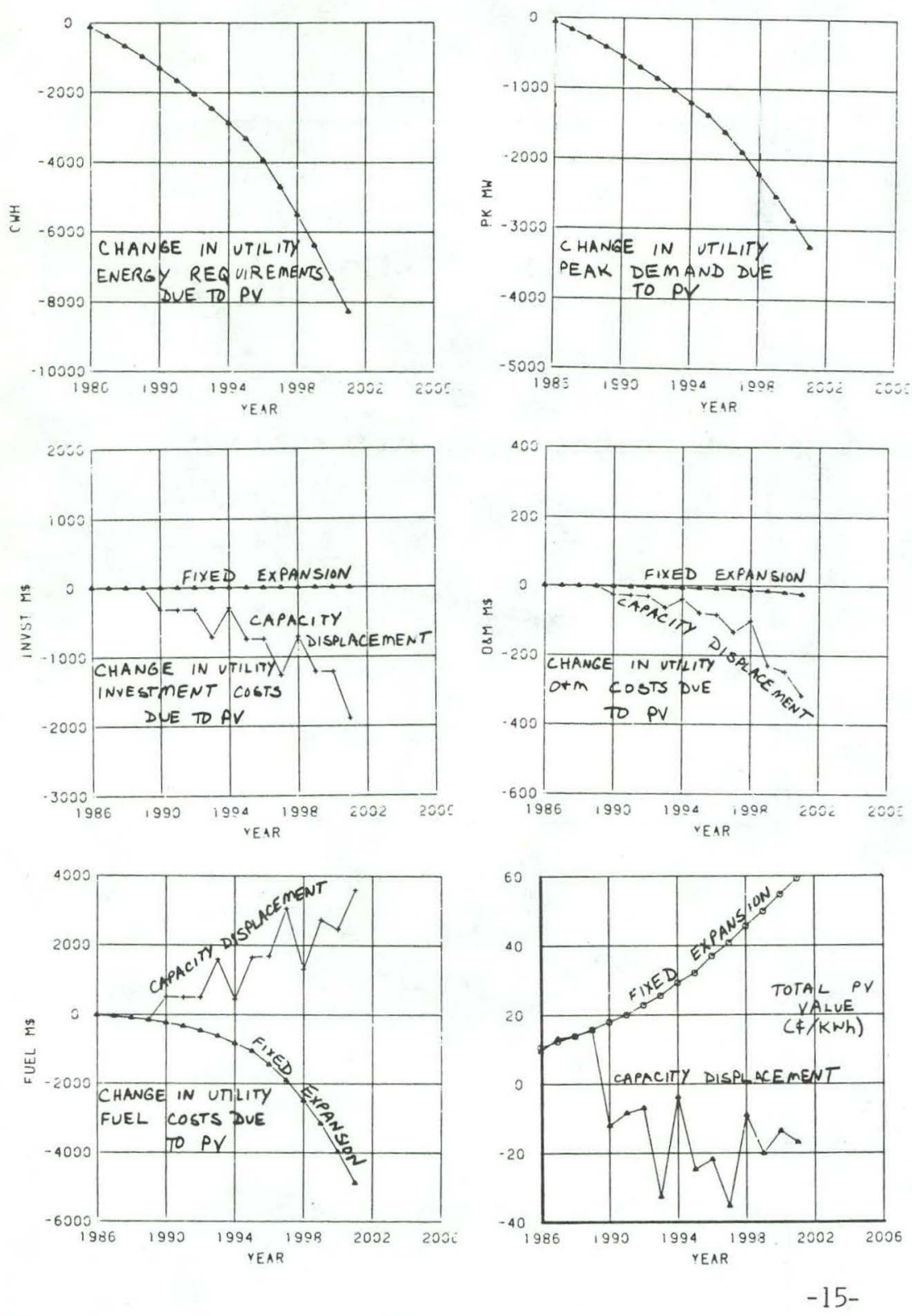

\section{ENERGY SCENARIO EFFECTS}

\section{Utility PV Value Analysis}

Conclusions:

o Key Factor - 0il Displacement

- High Impact - 0il Price or Use Scenarios

o PV Capacity Displacement - Net Penalty

- Most Interesting - WSCC South 


\section{ENERGY SCENARIO EFFECTS}

\section{UTILITY RATE STRUCTURE MOIEL}

- objective

$$
\text { Utility Savings } \Rightarrow \text { PV User }
$$

- Approach

Extrcpolate Historic Relationships

0 Result

Average Costs

Avoided Costs

\section{ENERGY SCENARIO EFFECTS}

Results Interrelationships

o Objective

Graphic Method Showing PV Cost/Benefit to User

0 Result

"Cut Card" Technique 


\section{WSCC-SOUTH AVOIDED COST}

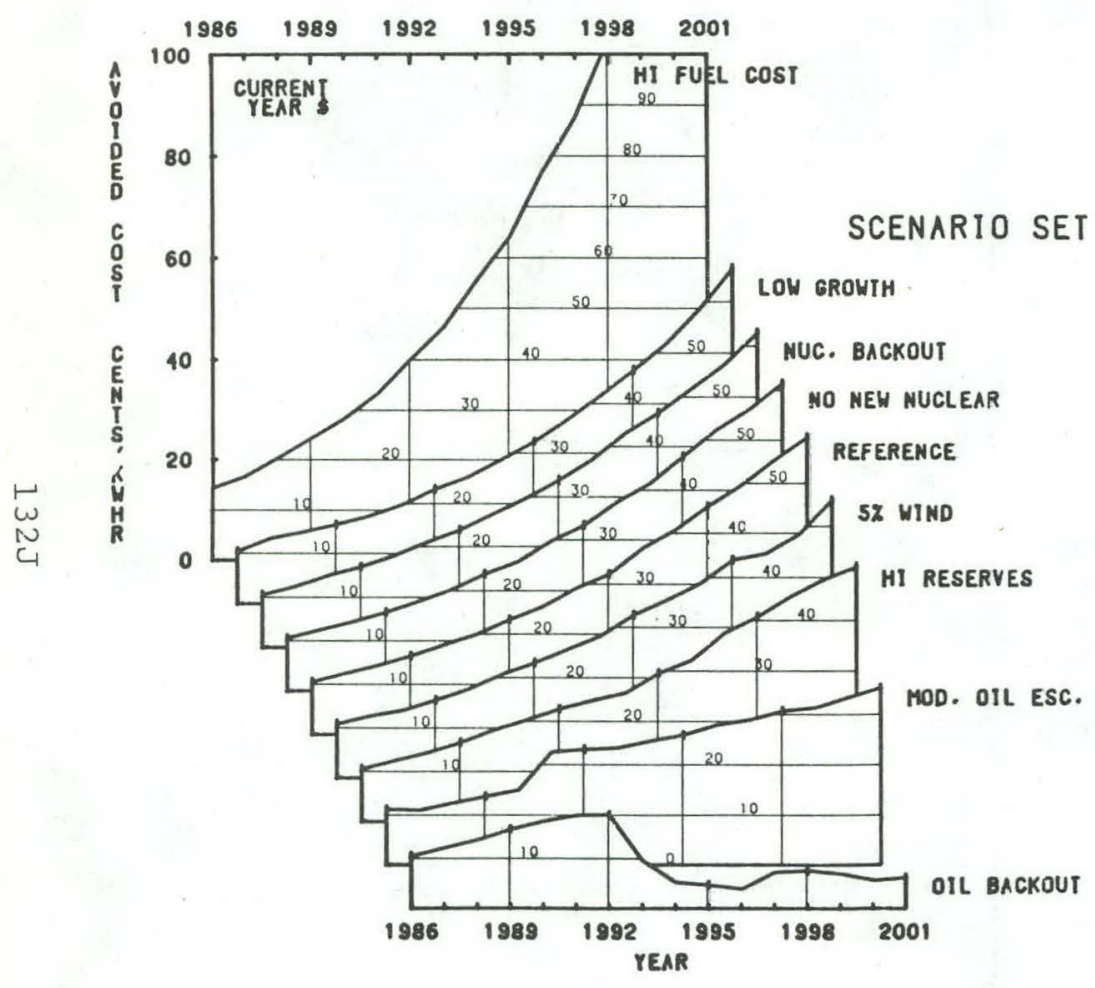

WSCC-SOUTH AVOIDED COST

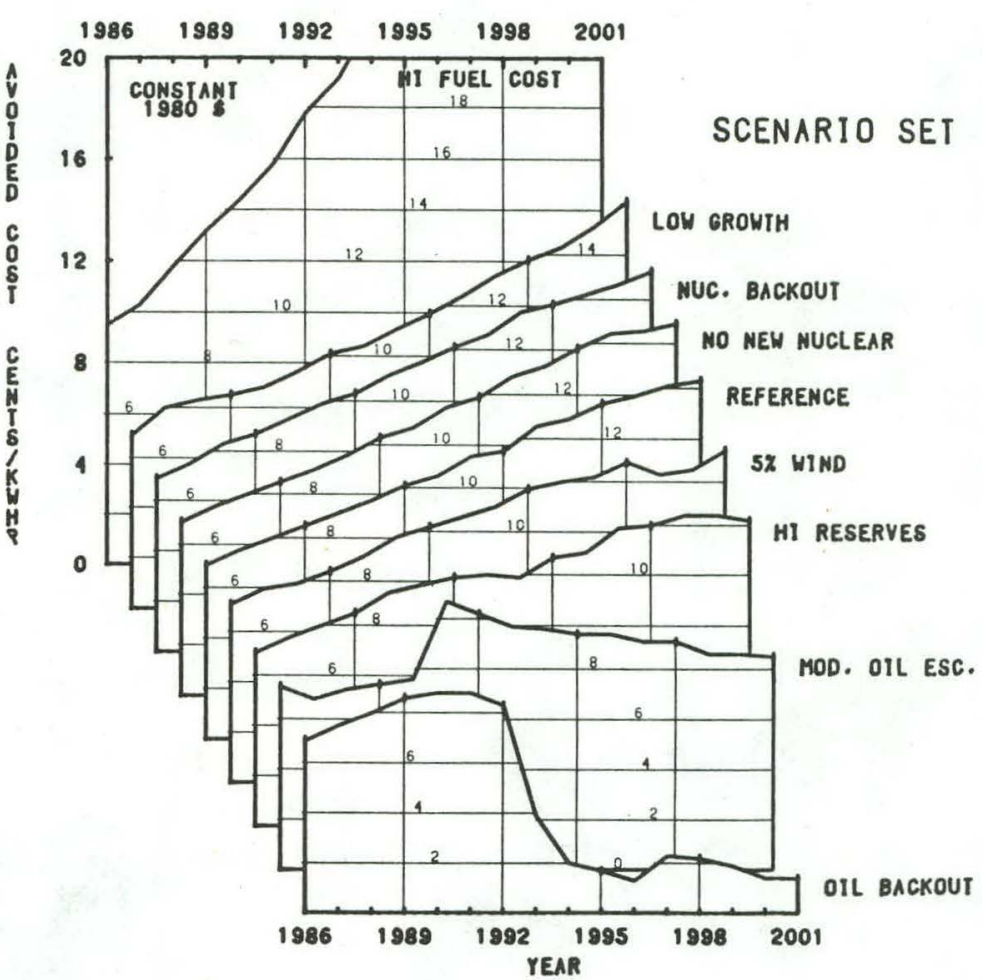


WSCC-SOUTH REF COSTS

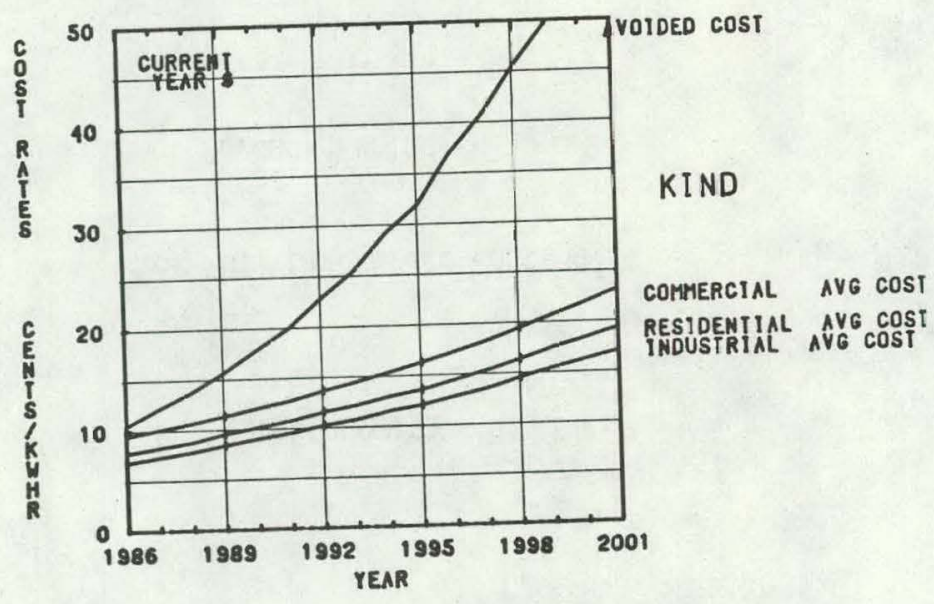

RESIDENTIAL AVERAGE COST

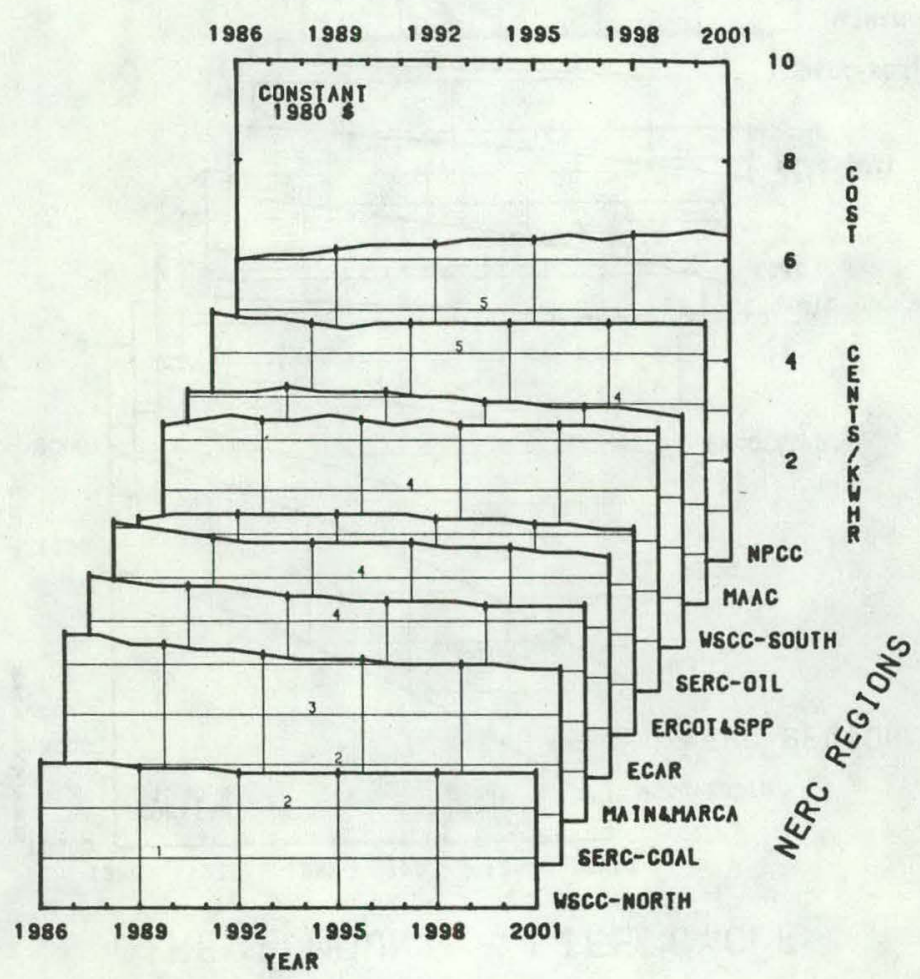

$-21-$ 
ENERGY SCENARIO EFFECTS

PV User Economics

- Full Life Cycle Costing

o Payback Period

\section{DIRECT MOUNT - LIFE CYCLE}

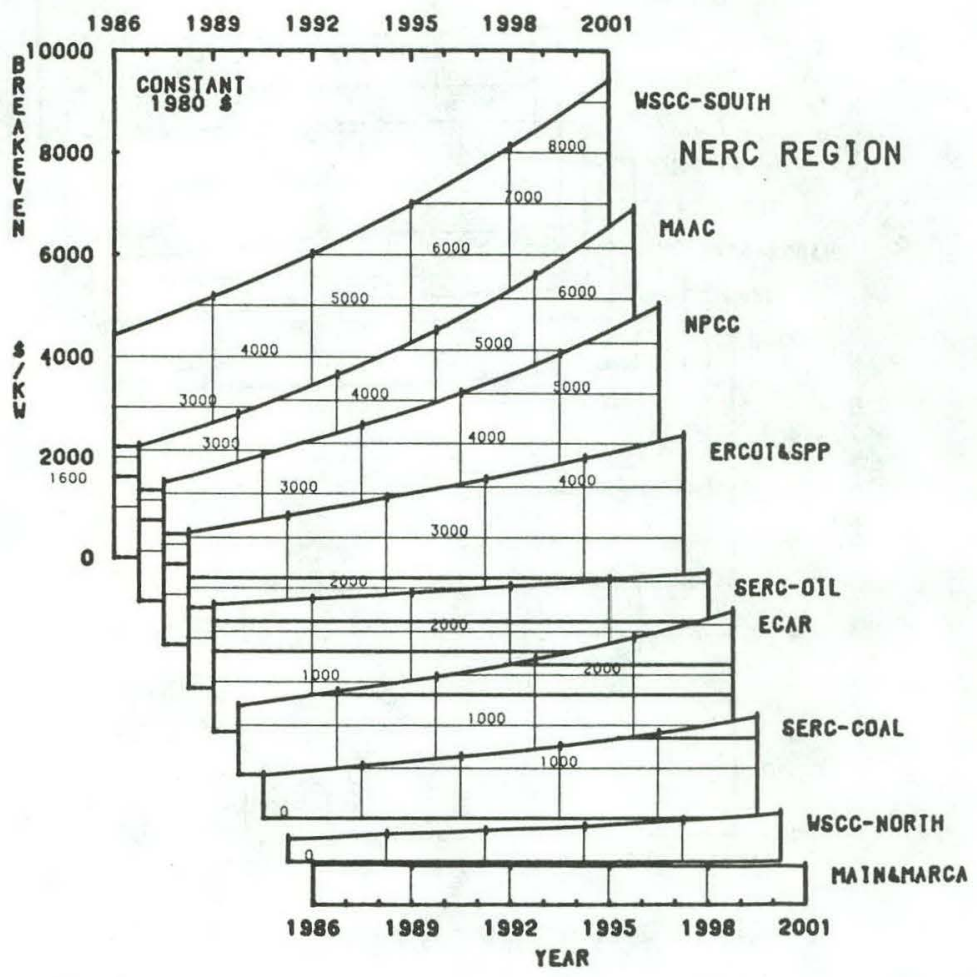




\section{POINT FOCUS 3 YR PAYBACK}

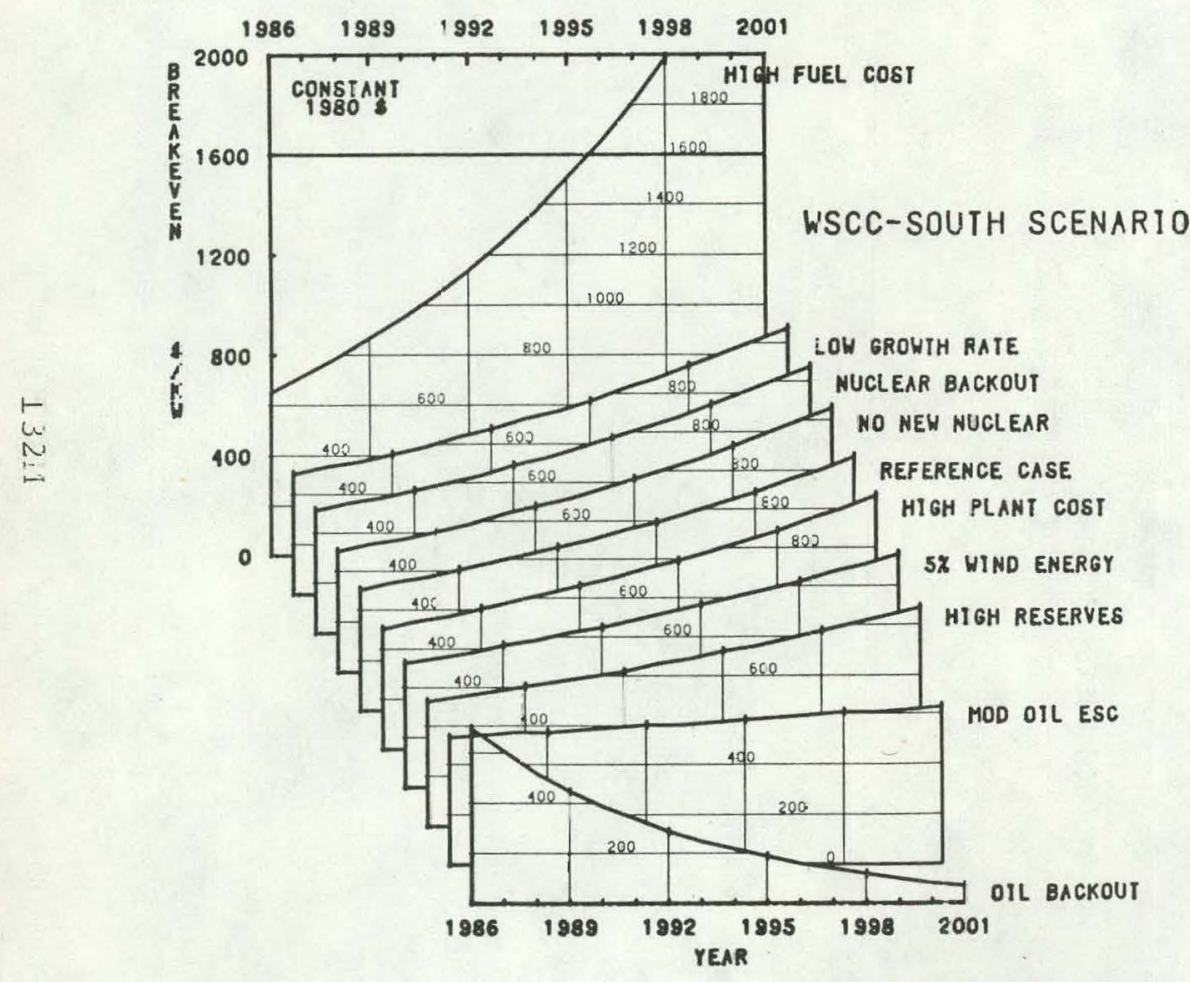

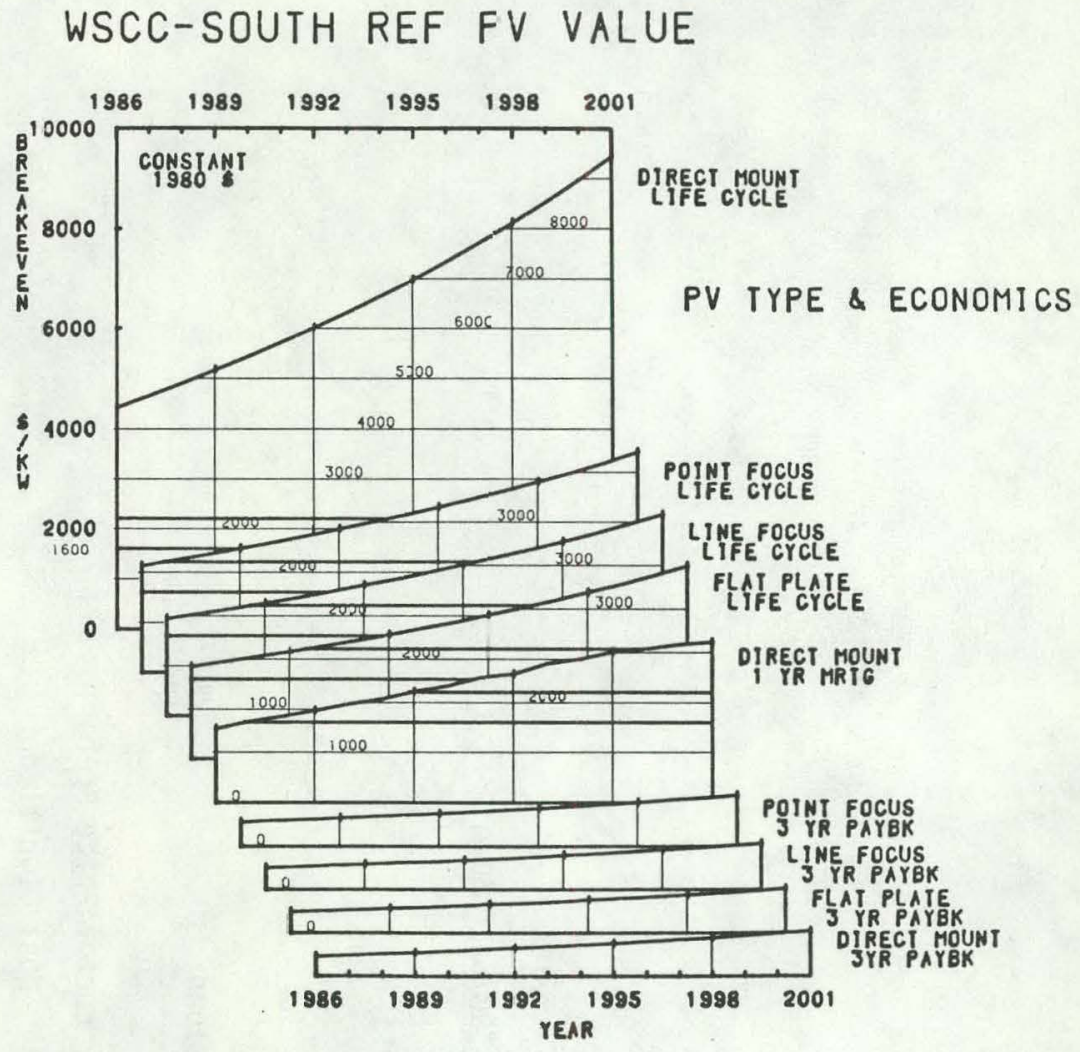

$-26-$ 
ENERGY SCENARIO EFFECTS

Conclusions:

- Energy Price Scenarios

Most Significant

- $0 i l$ Displacement Required for PV Viability

- Avoided Costs Required 
Array Subsystem Development

An Activity Overview

H. N. Post

Sandia National Láboratories

Al.buguerque, NM 87185

This presentation will provide an overview of array subsystem development activities at Sandia National Laboratories. Significant proyress has been made during the past year, especially in the area of optimized array field designs for medium-size systems. Recent estimates for flat-panel array field balance of system costs are projected at $\$ 50-60 / \mathrm{m}^{2}(1980 \$)$ of collector area for production quantities as low as $1 \mathrm{MW} / \mathrm{Yr}$. This represents a significant reduction from the typical PRDA-38 array field cost of $\$ 400 / \mathrm{m}^{2}$. Modular array field designs, including detailed working drawings and construction specifications, have been completed for system sizes of 20,100 and $500 \mathrm{~kW}$. Reports on these activities should be available during the early part of 1982. A parallel effort to develop building block designs for concentrator array fields is currently underway. The array field optimization activity will culminate with the installation of a prototype modular array field in the Sandia PV Test Facility by August 1982 .

Development activities for large-size array fields ( $>10 \mathrm{MW}$ ) have also made notable progress toward subsystem optimization and the reduction of installation costs. Key activities in this area include the subsystem optimization and tradeoff study, integrated structure designs, automated installation methods, and a new activity directed at system grounding and fault protection which is currently in a proposal evaluation phase. The subsystem optimization study has been completed and a final report on the work will be published shortly. 'l'his study piovides a comprehensive pvaluation of the optimum electrical subsystem for both flat panel and concentrator array fields. 'the integrated structure design activity is also near completion. The design developed during this work incorporates a $36 \mathrm{ft}$ long torque tube which is supported at each end by -extended concrete caissons. Total installed cost for this design is projected at $\$ 31 / \mathrm{m}^{2}$ for large production quantities. This structure design as well as a concentrator tracking structure/array design have been included in array field installation scenarins for the automated installation methods work. This study should establish the potential for installation cost reduction through the use of automated equipment and techniques.

Lastly, in keeping with the DOE PV program redirection, array subsystem development work is scheduled for phaseout during FY83. Documentation of results will be the principal planned activity during this phaseout period and no new activities are anticipated. 


\section{ARRAY FIELD ENGINEERING ACTIVITIES SUMMARY}

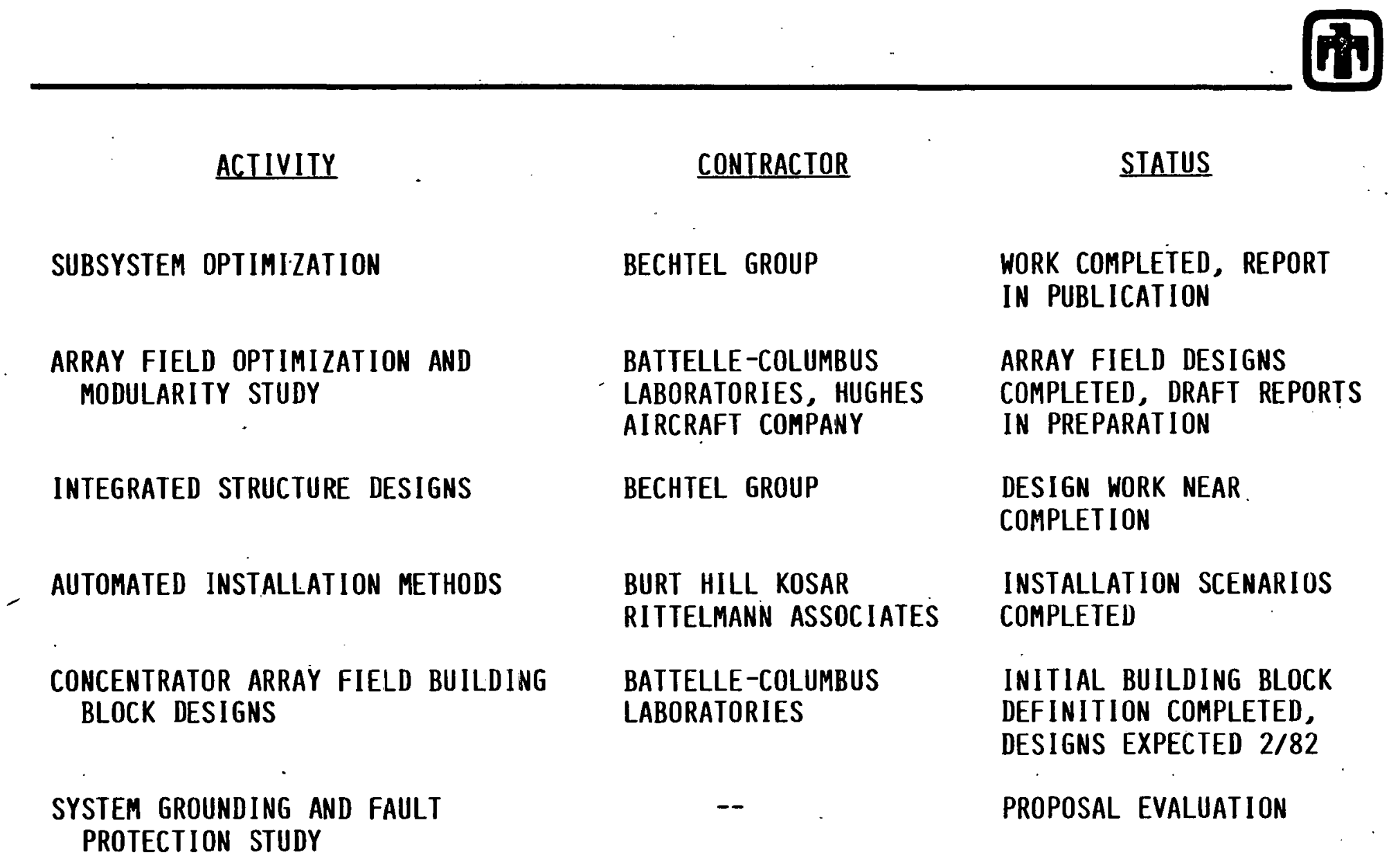




\section{ARRAY SUBSYSTEM DEVELOPMENT}

- Major Piroblem - Extremely high costs for array field bOS and engineering:

$$
\text { PRDA-38 EXPERIENCE } \begin{cases}\text { ENGR } & \$ 560 / \mathrm{M}^{2} \\ \text { BOS } & \$ 400 / \mathrm{M}^{2}\end{cases}
$$

- Technical Approach - Development and evaluation of innovative engineering CONCEPTS TO ACHIEVE LOWEST POSSIBLE LIFECYCLE COSTS

- Status - Completion of optimized, modular array field designs resulting in PROJECTED BOS COSTS OF $\$ 50 / \mathrm{M}^{2}-\$ 60 / \mathrm{M}^{2}$; SIGNIFICANT REDUCTION IN ENGINEERING COSTS THROUGH STANDARDIZED DESIGNS

- Planned Activities - Installation of modular arRay field building blocks in PV TEST FACILITY FOR TEST AND EVALUATION 


\section{MAJOR ARRAY FIELD ITEMS REQUIRING COST REDUCTION MEDIUM SIZE SYSTEMS (20-500kW)}

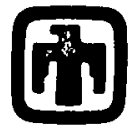

STRUCTURAL

SUPPORT

SUBSYSTEMS

$\$ 128 / m^{2}$

\section{COST REDUCTION \\ ACTIVITY}

COST

ARRAY FIELD

ENGINEERING

DESIGN

$\$ 2.58 / W_{p}$

$(28)$

DEVELOP STANDARDIZED

ARRAY FIELD DESIGNS

AND BUILDING BLOCK

HARDWARE; MINIMIZE

SIIE SPECIFIC DESIGN

WORK

USE LOW-COST FOUNDA-

TIONS; DEVELOP INTE-

GRATED PANEL/STRUC -

TURE HARDWARE; USE

SIMPLIFIED MECHAN ICAL

ATTACHMENT; MAXIMIZE

FACTORY PANEL ASSEMBLY

SITE PREPARATION

$\$ 136 / m^{2}$

SELECT SITES WITH

FAVORABLE CONDITIONS

(MINIMAL CLEARING AND

EX(AVATION WORK); RELAX

LEVELING REQUIREMENTS

FIELD WIRING

$\$ 153 / m^{2}$

MINIMIZE SUBARRAY

J-BOX INSTALLATION AND

INSTRUMENTATION; USE

QUICK-DISCONNECT CONNEC-

TORS; DEVELOP INTEGRATED

FIELD WIRING DESIGNS

\section{PROJECTED \\ NEAR TERM HUGHES BATTELLE \\ COST}

$\$ 0.20 / W_{p} * \quad \cdots \quad \$ 0.07 / W_{p}$

$\$ 45 / \mathrm{m}^{2} \quad \$ 33.15 / \mathrm{m}^{2} \quad \$ 27.82 / \mathrm{m}^{2}$

$\$ 18 / \mathrm{M}^{2} \quad \$ 10.72 / \mathrm{m}^{2} \quad \$ 8.07 / \mathrm{m}^{2}$

$\$ 15 / M^{2} \quad \$ 15.87 / M^{2} \quad \$ 16.04 / m^{2}$

•100kH SYSTEM SIZE 


\section{ARRAY SUBSYSTEM DEVELOPMENT}

\section{PROGRAM STATUS}

- Completion of Development Activities During fy82

- Phase Out Completed During fy83

- Documentation of Results

- No New Activities 


\title{
PHOTOVOLTAIC FLAT-PANEL ARRAY FIELD OPTIMIZATION AND MODULARITY STUDY
}

\author{
by \\ D. Carmichael, G. Alexander, and G. Noel \\ Battelle-Columbus Laboratories \\ 505 King Avenue \\ Columbus, Ohio 43201
}

Experience with the application experiments and other photovoltaic field installations to date has demonstrated that array-field balance-of-system (BOS) and engineering costs must be substantially reduced before photovoltaic power systems can be cost effective for grid-connected applications. Based on actual cost data for a representative application experiment (a 100-kW-peak flat-panel, ground-mounted installation), the array-field BOS costs were $\sim \$ 400 / \mathrm{m}^{2}$ and engineering costs were $\sim \$ 550 / \mathrm{m}^{2}$ of collector area. These costs are far too expensive for widespread commercial interest, regardless of the cost of photovoltaic modules. This study was conducted by Battelle and its subcontractors to develop an optimized, modular array-field design to reduce significantly these costs for ground-mounted flat-panel photovoltaic array fields.

The specific objectives of the study were (1) to develop innovative and integrated designs for the structural and electrical array-field subsystems and (2) to incorporate these designs in a standardized, modular building block which can be used to construct various sizes of photovoltaic array fields at minimum lifecycle energy cost. The subsystem areas investigated included the support structure, foundation, site preparation, field wiring, module wiring, grounding, lightning protection, and EMI-suppression considerations.

The modular array-field design developed is applicable for near-term (1982-1983) implementation and reduces the array-field balance-of-system initial costs to a fraction of those previously experienced. The design also incorporates improved reliability relative to comparable existing installations and minimizes maintenance requirements and costs. For the standardized building-block design, initial array-field BOS costs are estimated at approximately $\$ 52 / \mathrm{m}^{2}$ in 1980 dollars, for production quantities as low as $1 \mathrm{MW} / \mathrm{yr}$. No major capital investment in plant or equipment is required to implement the design. A detailed Project Manual and Construction Specifications and a complete engineering Drawing Package have been prepared for the building block design. Included as examples are field layout drawings of 20-, 100-, and 500-kW-peak $(2,10$, and 50 building blocks, respectively) array-field installations using the developed design. 


\title{
PHOTOVOLTAIC ARRAY FIELD OPTIMIZATION AND MODULARITY STUDY
}

Contractor: Battelle's Columbus Laboratories

\author{
Subcontractors: K\&A Engineers \\ Motorola \\ Arco Solar \\ Mission Research
}

Presentation at

Photovoltaic Systems and Applications Project Integration Meeting

Albuquerque, New Mexico

February 9-11, 1982

By Don Carmichael 


\section{OBJECTIVE}

TO REDUCE SIGNIFICANTLY THE COST OF FLATPANEL, GROUND-MOUNTED PV INSTALLATIONS BY DEVELOPING AN ARRAY-FIELD DESIGN WHICH IS

- COMPLETELY INTEGRATED AND OPTIMIZED FOR MINIMUM LCE COST

- MODULAR FOR USE AS A BUILDING BLOCK IN VARIOUS SIZE INSTALLATIONS

- STANDARDIZED TO REDUCE GREATLY THE SITESPECIFIC DESIGN AND INSTALLATION COSTS

- IMMEDIATELY APPLICABLE WITHOUT REQUIRING FACTORY/EQUIPMENT WITH LARGE INVESTMENT OR LONG LEAD TIME 


\section{GENERAL APPROACH}

- TAKE ADVANTAge OF AVAILABLE EXPERIENCE, INFORMATION, AND IDEAS

- INCORPORATE INNOVATIVE DESIGNS AND INSTALLATION METHODS TO MINIMIZE ARRAYFIELD COSTS

- DEVELOP COMPLETELY INTEGRATED DESIGNS FOR LOW-COST STRUCTURAL AND ELECTRICAL SUBSYSTEMS

- DEVELOP A STANDARDIZED ARRAY-FIELD BUILDING BLOCK DESIGN TO ELIMINATE THE COST OF CUSTOM DESIGN, FABRICATION, AND INSTALLATION 


\section{SCOPE}

- ARRAY-FIELD BALANCE-OF-SYSTEM (BOS) COMPONENTS INCLUDED IN DESIGN AND COSTING

- STRUCTURE - FIELD WIRING

- FOUNDATION - MODULE WIRING

- SITE PREPARATION - INTERMODULE WIRING

- FENCE - GROUNDING

- LIGHTNING PROTECTION - EMI SUPPRESSION

- NO PV MODULE OR POWER CONDITIONING DEVELOPMENT, BUT THEIR REQUIREMENTS CONSIDERED 


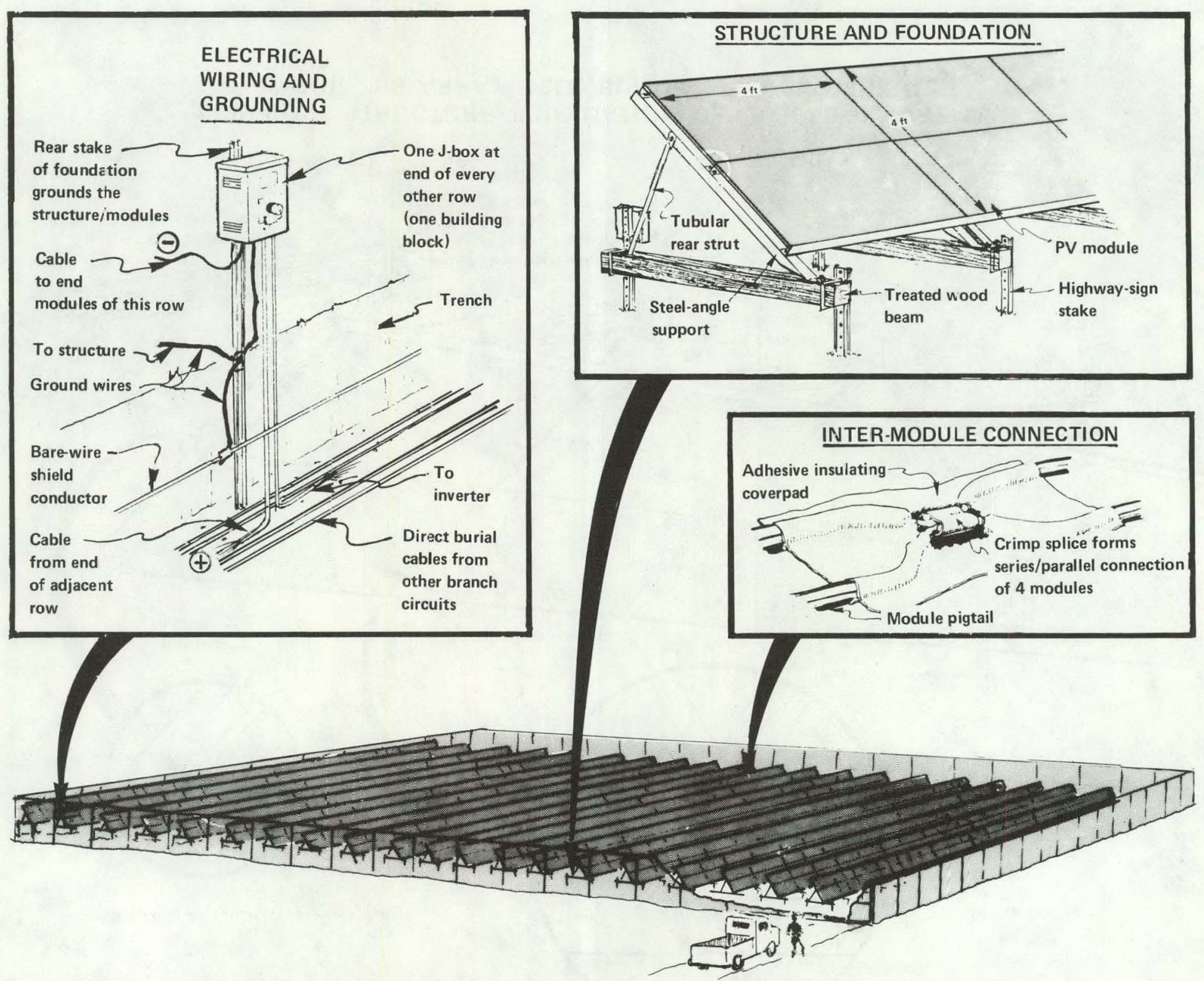

PHOTOVOLTAIC ARRAY FIELD USING BATTELLE'S LOW-COST BUILDING BLOCK DESIGN $100-\mathrm{kW}$ Array field consists of 10 building blocks, 2 rows each. Size to fence is $\sim 185 \times 195 \mathrm{ft}$. 


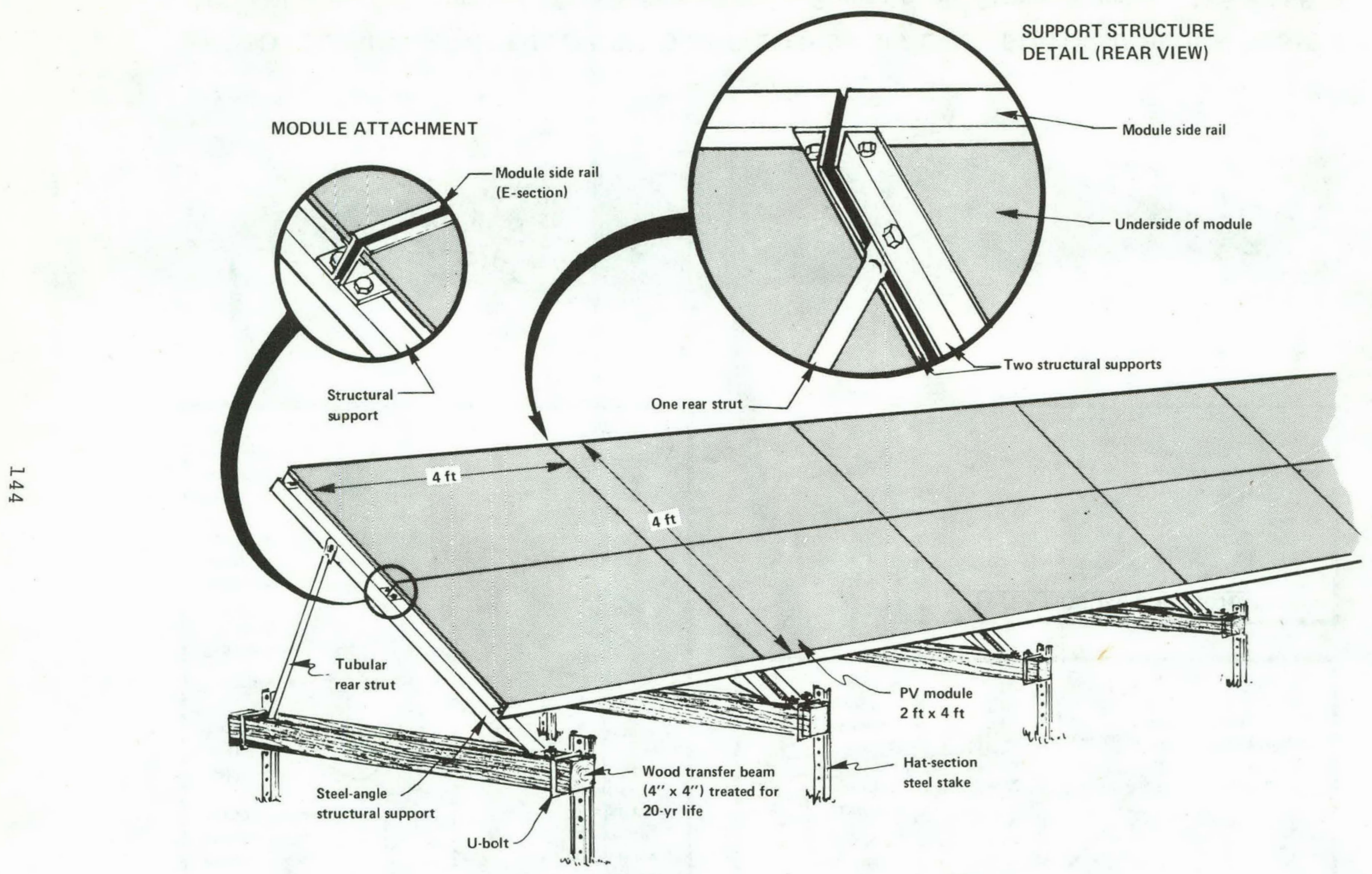

LOW-COST STRUCTURE/FOUNDATION DEVELOPED BY BATTELLE FOR THE ARRAY-FIELD BUILDING-BLOCK DESIGN 


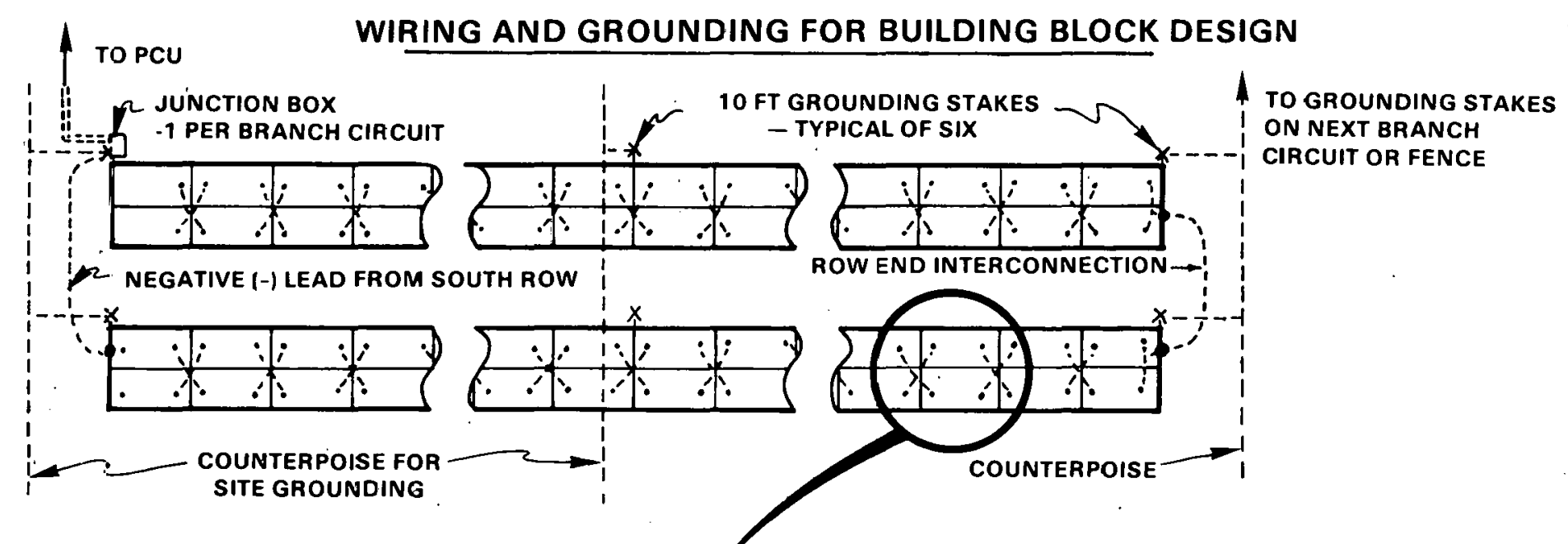

BRANCH CIRCUIT/BUILDING BLOCK (1 BRANCH CIRCUIT = 1 BUILDING BLOCK)

- 400 VDC $\otimes 24.4$ A TYPICAL

$\therefore 9.75 \mathrm{~kW}\left(800 \mathrm{~W} / \mathrm{m}^{2}\right.$. NOCT. $10 \%$ EFFICIENCY)

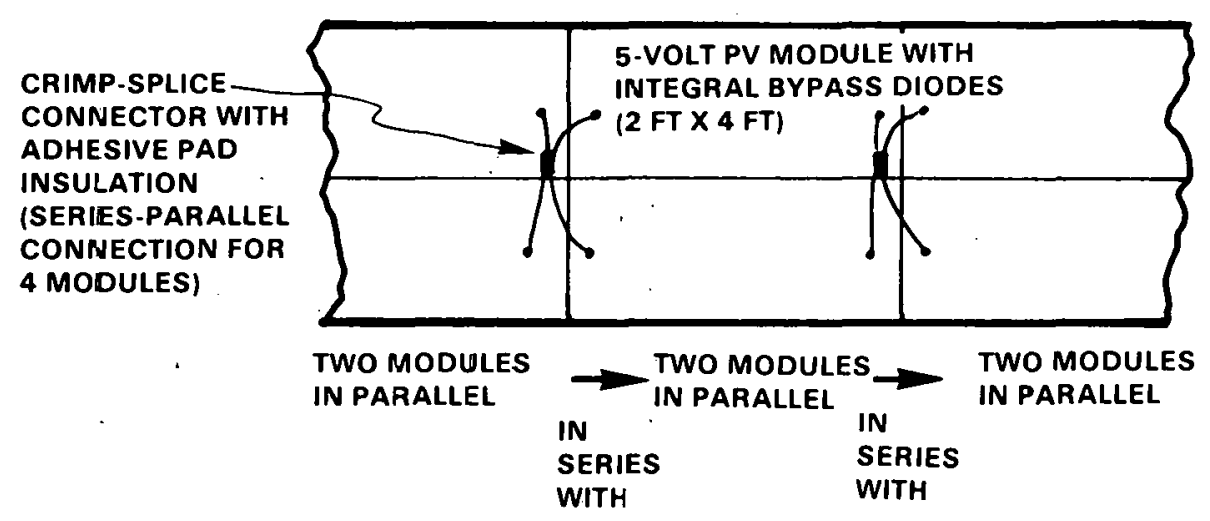

- 164 PV MODULES, 2 MODULES (IN PARALLEL) PER PANEL 


\section{CHARACTERISTICS OF THE MODULAR ARRAY FIELD BUILDING BLOCK DESIGN}

- PV MODULE $\quad-2 \times 4$ FT; 5 VDC OUTPUT; PARALLEL CELL STRINGS; INTEGRAL DIODES

- FOUNDATION - STEEL HAT-SECTION STAKES; WOLMANIZED $4 \times 4$ IN. WOOD BEAMS

- StRUCTURE - LIGHTWEIGHT STEEL ANGLE AND TUBING; TWO-MODULE PANEL (4x4 FT)

- BRANCH

- 10 kW PEAK OUTPUT @NOC CIRCUIT WITH 10\% EFFICIENT MODULES;

〜400 VDC @NOC; TWO MODULES IN PARALLEL; 82 PAIRS IN SERIES

- INTERMOdULE - MOdULE PIGTAILS JoINED BY WIRING 4-WIRE CRIMP SPLICE WITH INSULATING PAD

- FIELD WIRING - DIRECT BURIAL FEEDER CABLES

- BUILDING BLOCK SIZE

- $10 \mathrm{~kW}$ PEAK OUTPUT AT 400 VDC (@NOC)

TWO ROWS OF STRUCTURE

165 FT EAST-WEST BY 18 FT NORTH-SOUTH INCLUDING AISLEWAYS

- COST

- ARRAY FIELD BOS INSTALLED PRICE $\sim \$ 52 / \mathrm{m}^{2}(1980 \$)$ 


\title{
PHOTOVOLTAIC ARRAY \\ FIELD OPTIMIZATION AND MODULARITY STUDY
}

\author{
John A. Castle \\ Hughes Aircraft Co. \\ P.0. Box 90515 \\ Los Angeles, Ca. 90009
}

The detail design of an array field modular building block has been developed. This design represents a low cost modularized array field increment that can without additional engineering effort be used to implement larger array fields. Desired safety, maintenance, and operational features are provided by this expandable design concept with minimum cost penalty.

$A \pm 200$ volt bipolar system was selected in lieu of a higher voltage monopolar system. This allowed the use of lower cost power components such as switch gear, MOVs, blocking diodes etc., and provides for convenient power distribution, erihanced safety and sectionalization features. System concepts evaluated included circuit configurations using 5 and 15 volt PV modules. Results of circuit performance studies showed that use of 5 volt modules reduced life time power loss. This is a result of using additional parallel circuits of solar cells protected by a by-pass diode.

The merits of wiring PV modules in parallel horizontal rows were verified and adopted. This geometrical orientation reduces energy loss due to row to row shading and variations in diffuse radiation along the slant height of the panels. A folded version of a daisy chain, module to module wiring concept, was adopted where the circuits run in horizontal rows and fold back on themselves so that all input-output leads terminate in a common junction box at one end of a subarray structure. This approach eliminates the need for a return cable and minimizes the wire power dissipation losses. Several module to module wiring methodologies were studied. The approach finaliy selected uses a quick disconnect cable assembly manufactured by Amp Inc. Primary advantages are reduced installation costs while minimizing safety hazards during installation and facilitates module diagnostics and replacement.

The final array field modular building block developed is a \pm 200 volt bipolar unit with a nominal output power rating of $10 \mathrm{~kW}$. It consists of two 200 volt monopolar subarrays positioned in a east-west oriented row. Each subarray structure is 160 feet long and acculinudates two parallel cirruits of 40 series connected 5 volt PV modules. Each subarray contains 40 panels. A panel consists of four 2 toot by 4 foot size modules, which are mounted to side rails where the modules act as part of the panel structure. The panel side rails are attached at the appropriate tilt angle to steel stanchions secured in a front and.rear row hybrid foundation at four foot intervals. The front row foundation is a buried metal foot structure that is positioned in a trench and earth backfilled. This metal structure acts as a buried ground counterpoise and is an integral part of a grounding net. The rear row foundation is a concrete curb designed to withstand the primary wind lifting forces.

Power from cach building hlock is routed from a subarray junction box to a power collection center (PCC) via direct burial cable. The PCC contains a sldildaid circuit breaker switch and bus panel, fault detection sensing, and a power control module (PCM) for every two building blocks. A PCM contains MOVs, blocking diodes, snubers, and crowbar. The array field is thus sectionalized from a control standpoint in $20 \mathrm{KW}$ increments. The Life cycle costs (excluding module costs in 1980 dollars) is projected to be approximately $\$ 100 / \mathrm{m}^{2}$ for friendly sites at a production voluine of $10 \mathrm{MW}$ per year. A draft final report for this study is presently being prepared. 
The final array field modular building block developed is a +200 volt bipolar unit with a nominal output power rating of $10 \mathrm{KW}$. It consists of two 200 volt monopolar subarrays positioned in a east-west oriented row. Each subarray structure is 160 feet long and accommodates two parallel circuits of 40 series connected 5 volt PV modules. Each subarray contains 40 panels. A panel consists of four 2 foot by 4 foot size modules, which are mounted to side rails where the modules act as part of the panel structure. The panel side rails are attached at the appropriate tilt angle to steel stanchions secured in a front and rear row hybrid foundation at four foot intervals. The front row foundation is a buried metal foot structure that is positioned in a trench and earth backfilled. This metal structure acts as a buried ground counterpoise and is an integral part of a grounding net. The rear row foundation is a concrete curb designed to withstand the primary wind lifting forces.

Power from each building block is routed from a subarray junction box to a power collection center ( $P C C$ ) via direct burial cable. The PCC contains a standard circuit breaker switch and bus panel, fault detection sensing, and a power control module (PCM) for every two building blocks. A PCM contains MOVs, blocking diodes, snubers, and crowbar. The array field is thus sectionalized from a control standpoint in $20 \mathrm{~kW}$ increments. The Life Cycle costs (excluding module costs) in 1980 dollars is projected to be approxiamtely $\$ 100 / \mathrm{m}^{2}$ for friendly sites at a production volume of $10 \mathrm{MW}$ per year. 


\section{ARRAY FIELD OPTIMIZATION AND MODULARITY DESIGN STUDY}

\section{SYSTEM ATTRIBUTES}

-11.5 KW ARRAY (1000 W/M ${ }^{2}$ AT NOCT) BUILDING BLOCK

- 200 VOLT DC BI POLAR CONFIGURATION

- SECTIONALIZED ARRAY FIELD FOR

- MODULAR EXPANDIBILITY

- EASE OF MAINTAINABILITY/OPERABILITY

- FULL SYSTEM UTILITY INTERACTIVE COMPATIBILITY

- UNIQUE HYBRID LOW COST STRUCTURE/FOUNDATION

- FRAMELESS PANEL - DIRECT MODULE INSTALLATION

- SELF GROUNDING

- PV MODULES ARE CONNECTOR WIRED

- GROUND FAULT DETECTION

- LIGHTNING, TRANSIENT AND SURGE PROTECTION

- DIRECT BURIAL CABLES

- MINIMUM INSTRUMENTATION - NONE REMOTE

- RADIAL WIRING FOR POWER COLLECTION

- full compliance with national standardS/CODES

- STANDARD AC DISTRIBUTION IIARDWARE

- NO PV MODULE REPLACEMENT AFTER 1ST YEAR 

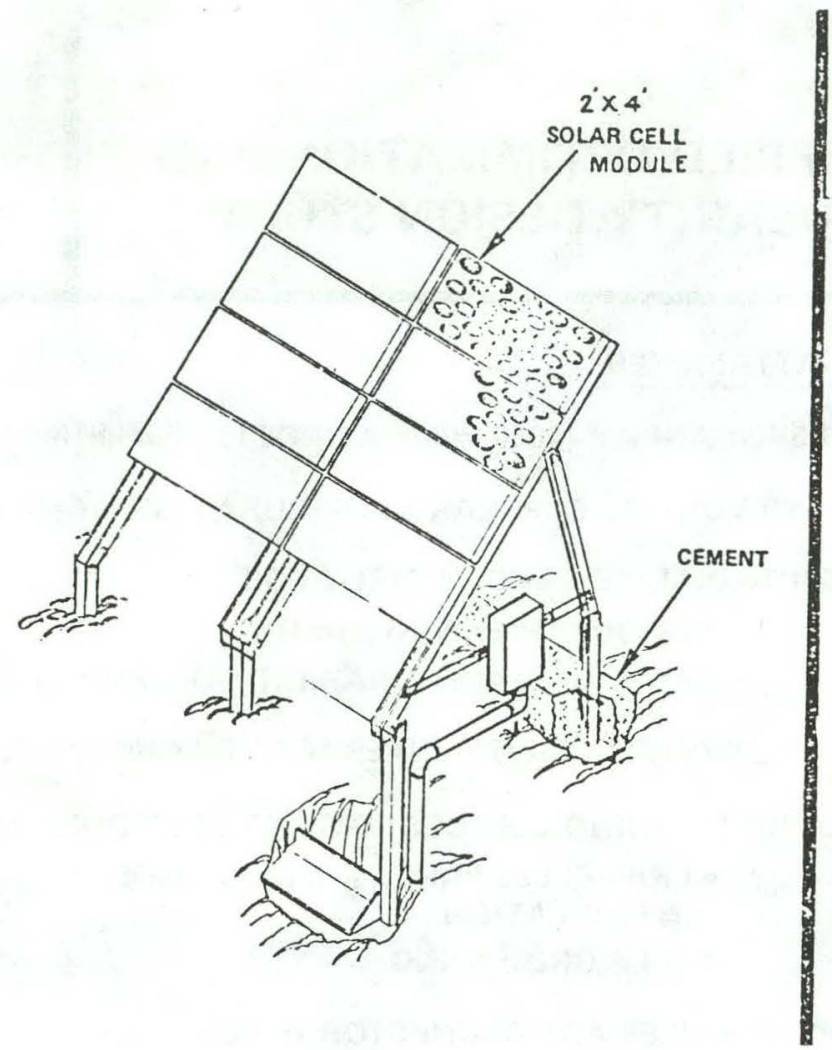

\section{STFUCTURE HYBRID FOUNDATION ASSERIBLY}

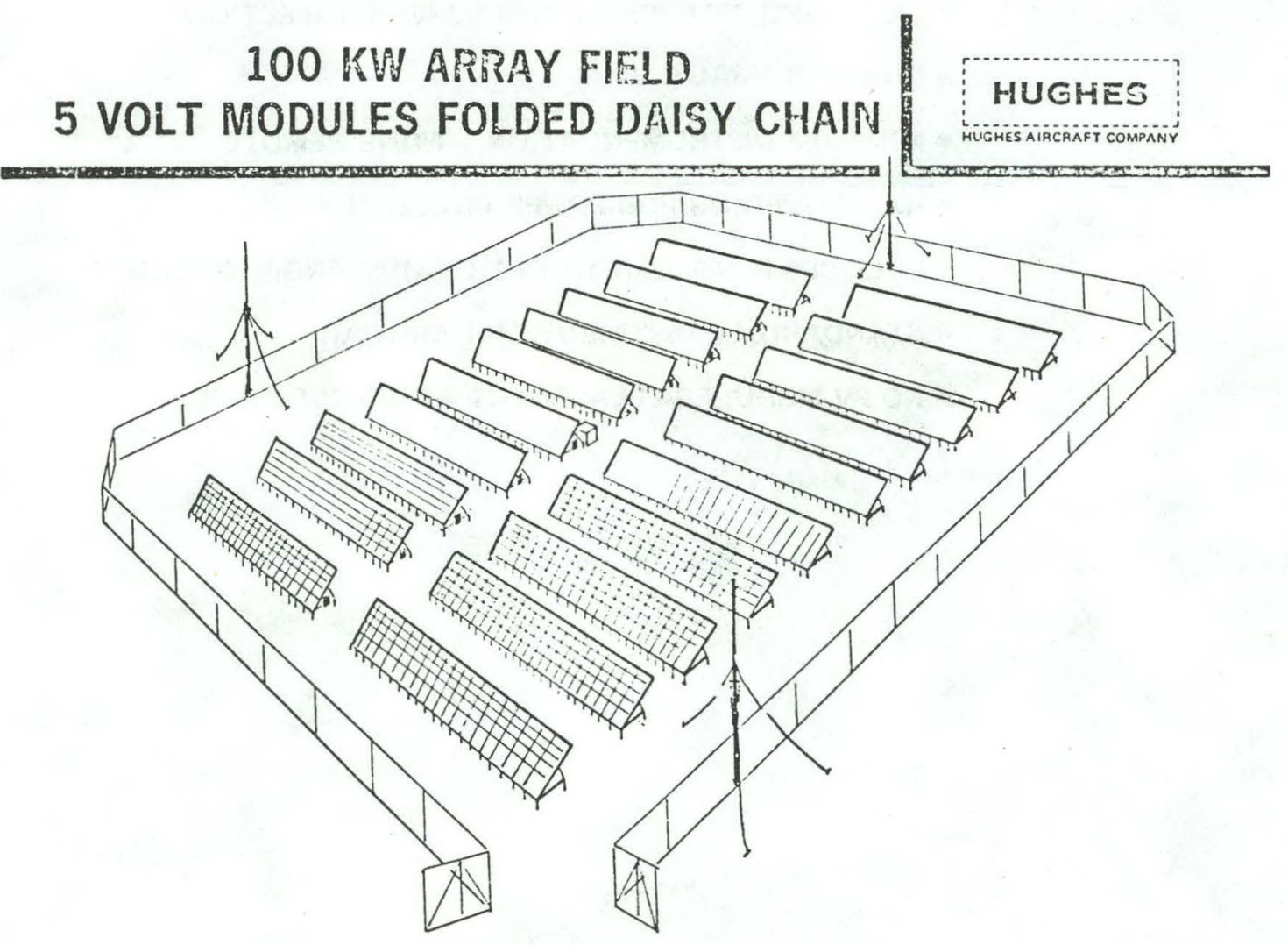




\section{BUILDING BLOCK JUNCTION
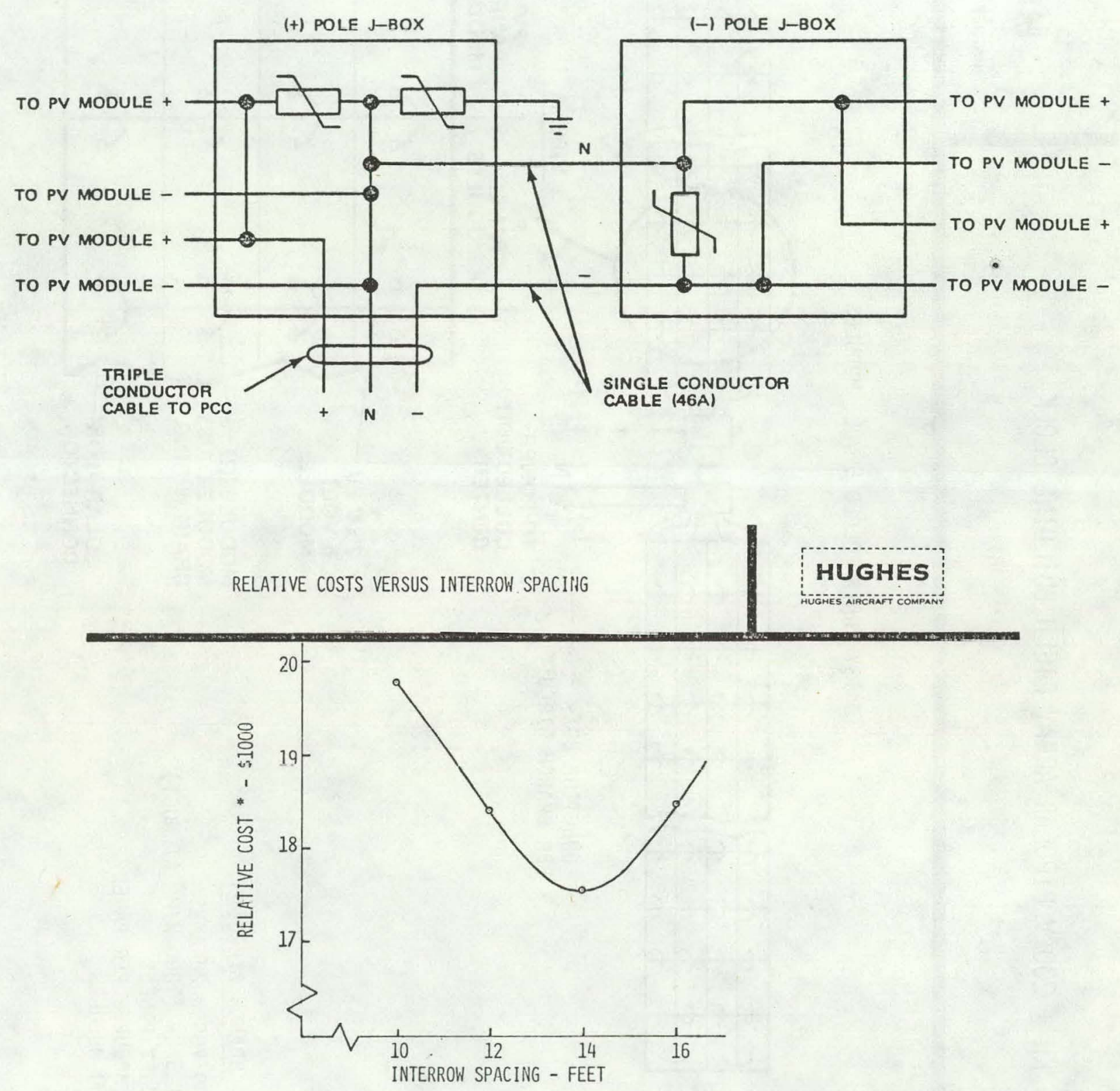

"INCLUDES: SHADOWING LOSSES a \$5/PK WATT, FENCING COSTS, LAND COSTS, WIRING COSTS AND LOSSES a \$5/PK WATT 


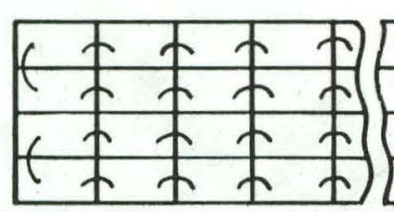

JUNCTION BOX-

2 PER BRANCH CIRCUIT

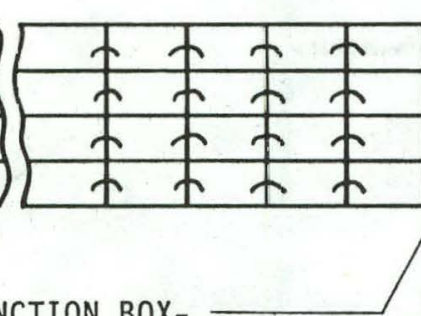
$\left.(+)\right|_{N} t(-)$

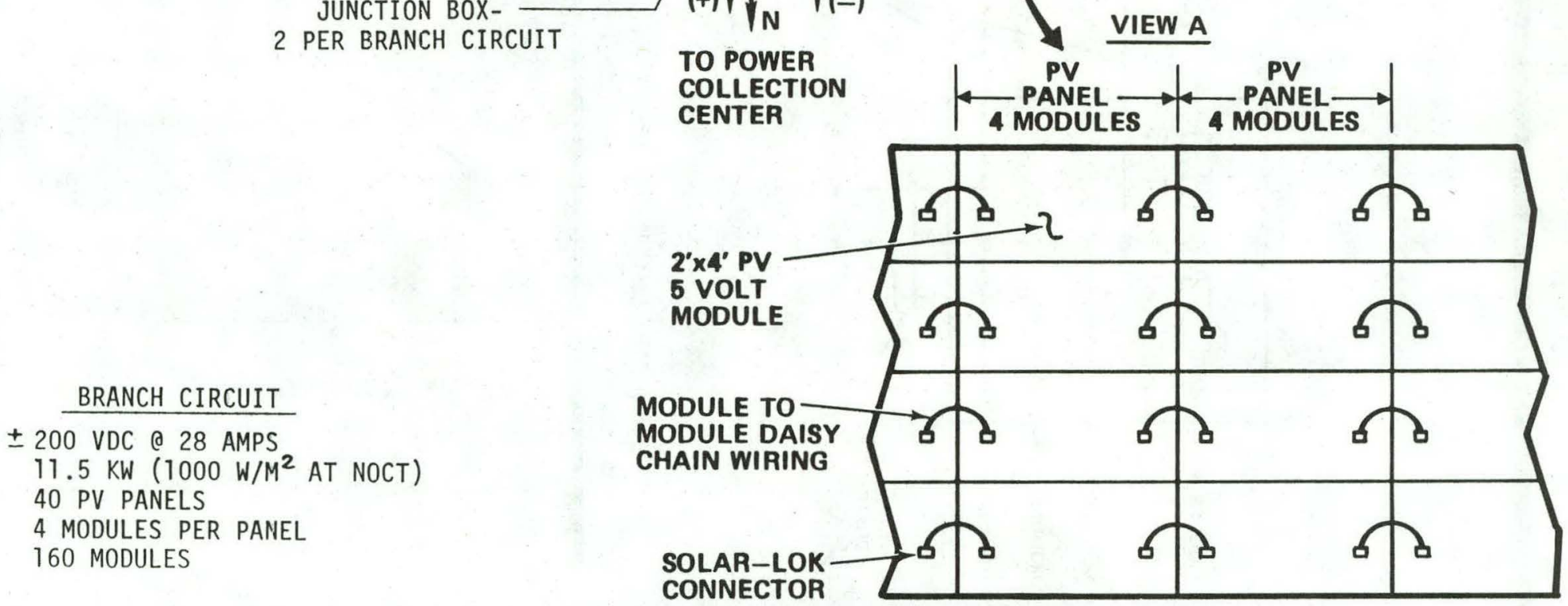




\section{FLOW DIAGRAM FOR $57 \mathrm{~kW}$ MODULAR PV POWER SYSTEM}

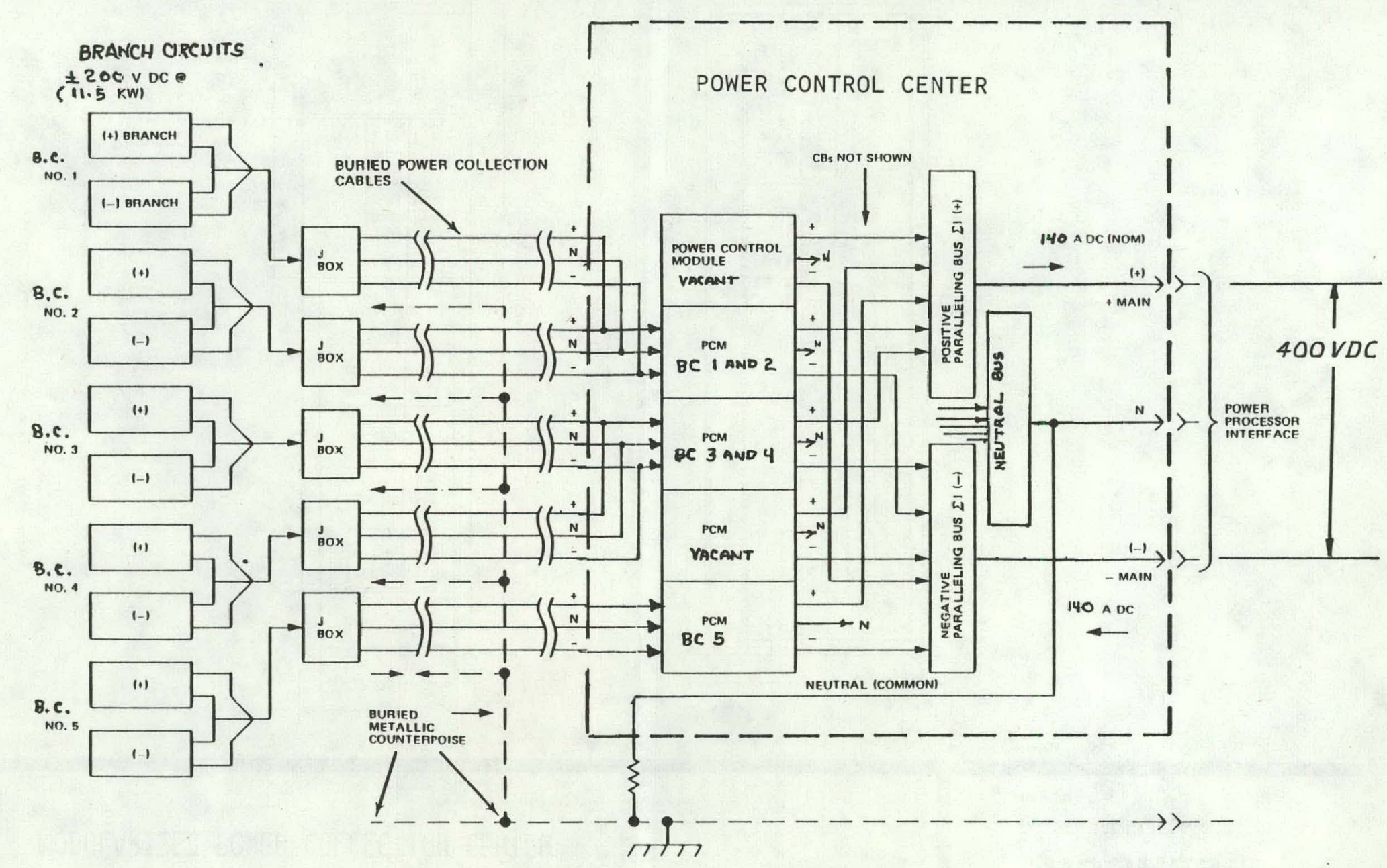


MODULARIZED POWER COLLECTION CENTER

\section{HUGHES}

HUGGEES AIRCRAFT COMMPĀNY

U.

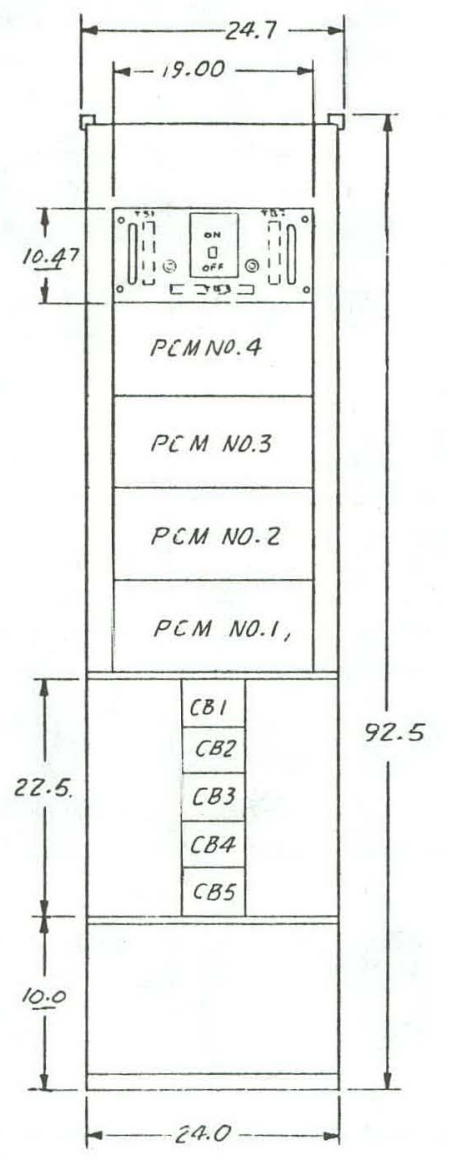

FRDIT VIEW

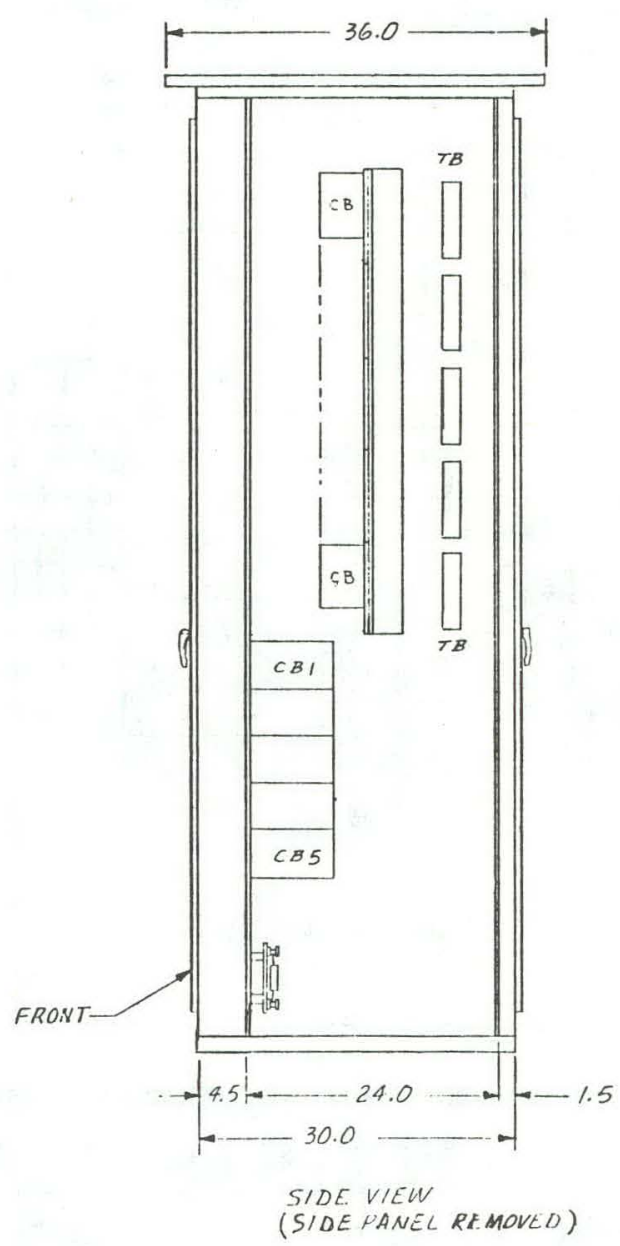



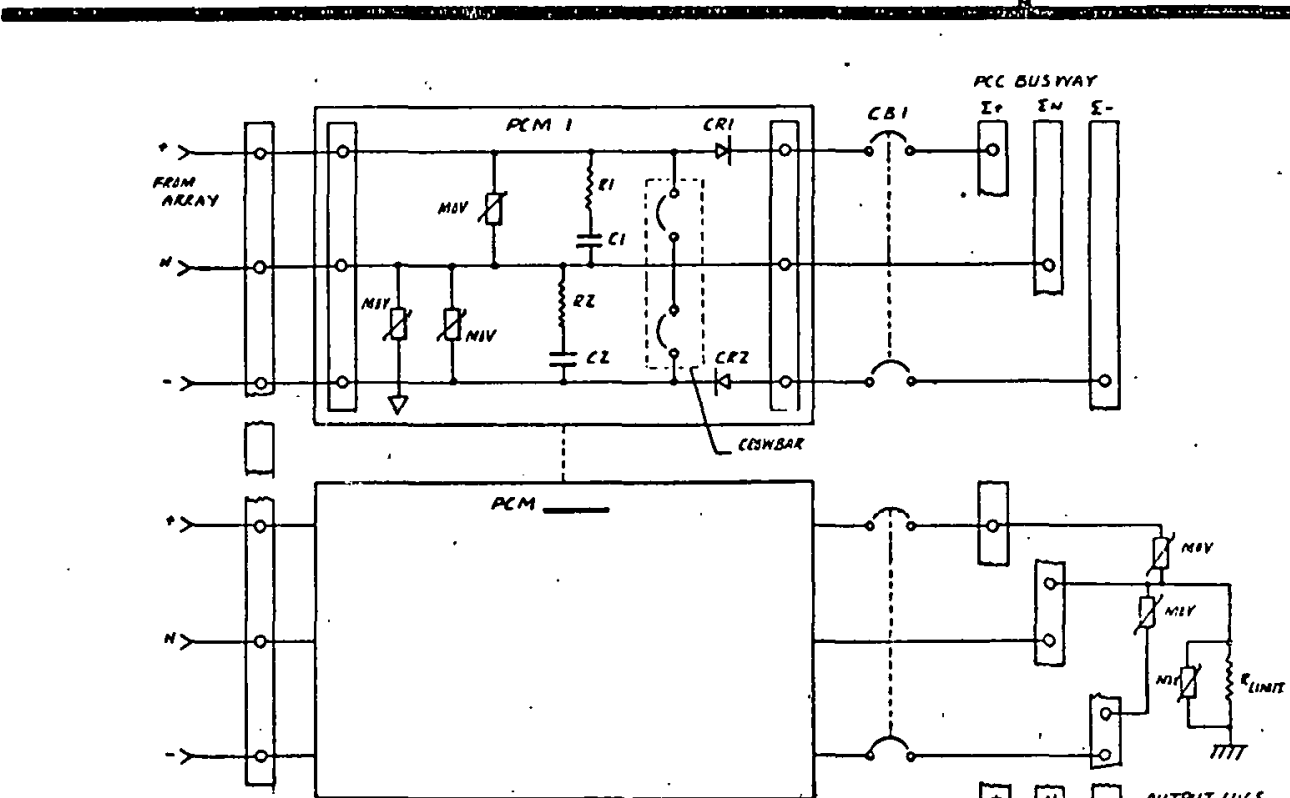

$\square \square \square$ outreyt LuGs

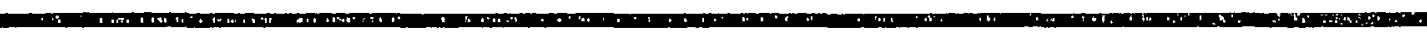

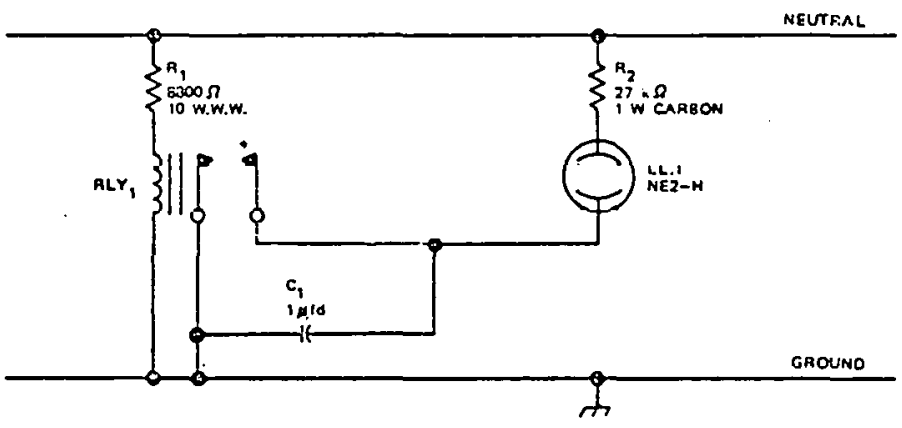




\section{ARRAY FIELD OPTIMIZATION AND MODULARITY DESIGN STUDY}

BALANCE OF SYSTEMS (BOS) 20 YEAR LCC*

PROGRAM MANAGEMENT

PROGRAM MGMT

CONSTRUCTION MGMT

SUSTAINING ENGR

SITE PREPARATION

SURVEY/CLEANING/LEVELING

GROUND COVER

FENCING

ELECTRICAL SUBSYSTEM

FIELD WIRING \& J-BOXES

POWER COLLECTION CENTER

LIGHTNING RODS

GROUNDING NET

$$
\begin{array}{ccc}
\frac{\text { BOS Costs }}{10.22} \stackrel{\$ / M^{2}}{\text { TOTALS }} & \\
9.09 & & \\
3.74 & & \\
& &
\end{array}
$$

1.70

2.04

5.72

$\overline{9.46}$

10.42

4.84

.74

2.76

$\overline{18.76}$

"BASED ON ANNUAL PRODUCTION OUTPUT OF $10 \mathrm{~mW}$

\section{ARRAY FIELD OPTIMIZATION AND MODULARITY DESIGN STUDY}

BALANCE OF SYSTEMS (BOS) (CONTINUED) $115 \mathrm{KW}$ SYSTEM .

STRUCTURAL

STRUCTURES

FOUNDATIONS

PANEL ASSEMBLY

TRANSPORTATION, CRATING,

LOADING \& STAGING

SYSTEM TEST/O\&M

SYSTEM CHECK OUT

O\&M - BOS

O\&M - PV MODULES

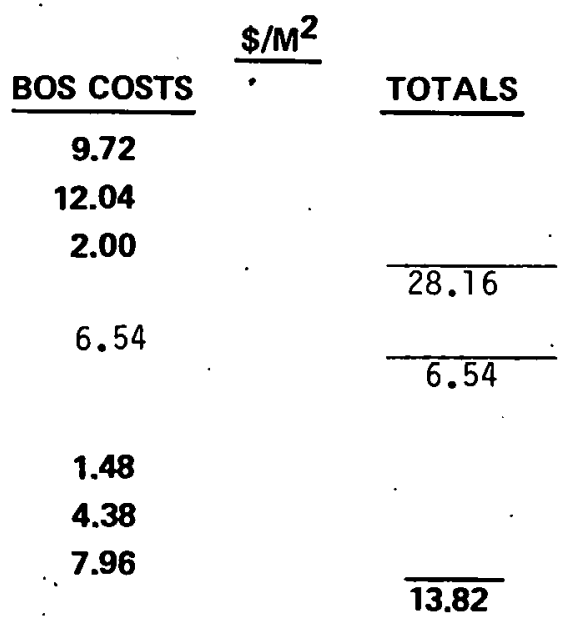




\title{
PHOTOVOLTAIC CONCENTRATOR ARRAY FIELD \\ OPTIMIZATION AND MODULARITY STUDY
}

by

\author{
G. Alexander, G. T. Noel, and D. C. Carmichael \\ Battelle-Columbus Laboratories \\ 505 King Avenue \\ Columbus, Ohio 43201
}

The overall objective of this study is to develop modularized photovoltaic (PV) concentrator array-field building block designs which minimize the field installation and wiring costs for two concentrator collector designs specified by Sandia. The building block designs will be suitable for use in multiples to construct lowcost medium-size and large-size array ficlds. Array ficld layouts for medium-size fields of 20-, 100-, and $500-\mathrm{kW}$ peak are to be prepared using the developed building blocks.

This study is directed to the incorporation of existing PV concentrator collectors into minimum cost array-field systems, rather than to the development of new PV concentrator module or array designs. Two specific concentrator designs have been selected for this study based on their long-range potential for low cost: (1) a point-focus Fresnel-lens concentrator array using a center-post mount and (2) a line-focus Fresnel-lens concentrator module mounted in a center and end-supported frame. Both systems are passively cooled and use two-axis tracking.

Specific objectives of the study are:

- To develop a modularized building block size/design which is applicable for use in installing array fields of nominally $20-\mathrm{kW}$ peak and larger, for each of two existing and specified PV concentrator collectors.

- To design nominal 20-, 100-, and 500-kW array field layouts using the developed building blocks for the two specified PV concentrators

- To develop and deliver working drawings, specifications, and cost estimates for each of the modularized array-field designs including site layout and requirements, field wiring, and controls, utilizing the specified collectors.

Recommended building block sizes have been established for both the E-Systems (line-focus Fresnellens concentrator) and the Martin-Marietta (point-focus Fresnel-lens concentrator) second-generation array designs. The building block sizes are based on considerations of desired array field operating voltage, compatibility with specified array field sizes, array performance characteristics, and other factors. Shading analyses using computerized models are being performed to define appropriate inter-array spacings for the two array designs. Recommendations of spacings for a baseline case of $35^{\circ}$ north latitude (Albuquerque) and for a range of other latitudes representative of the continental United States are being developed with the assistance of E-Systems and Martin-Marietta. Present baseline case concepts include an inter-row spacing of approximately $13 \mathrm{ft}$ for the E-Systems design and a closest center-to-center pedestal spacing of approximately $58 \mathrm{ft}$ for the Martin-Marietta design. 
Both of the array designs being considered use post-type foundations. Data on the structural designs, their capabilities (i.e., withstanding forces), and appropriate site conditions and requirements have been collected. These will be tabulated for use in assessing specific site situations.

Control system requirements which are compatible with the modularized building block concept have been determined. In-depth analyses of E-Systems' and Martin-Marietta's control schemes have been performed to assess their adaptability to the modularized approach. The Martin-Marietta system appears to be directly applicable in this respect. The E-systems control system requires modification to provide the most economical configuration for implementing large array fields. Data on several alternative array field control systems have been collected and are being evaluated.

Designs for 20-, 100-, and. 500-kW array field sizes are being developed for each of the two concentrator module/array designs using the modular building blocks as a basis. Sets of specifications and detailed site and electrical drawings (including control and power wiring drawings) will be prepared for each design. Cost estimates, using the manufacturers' cost projections for the module/array itself, will be developed for the modular array field installations. 


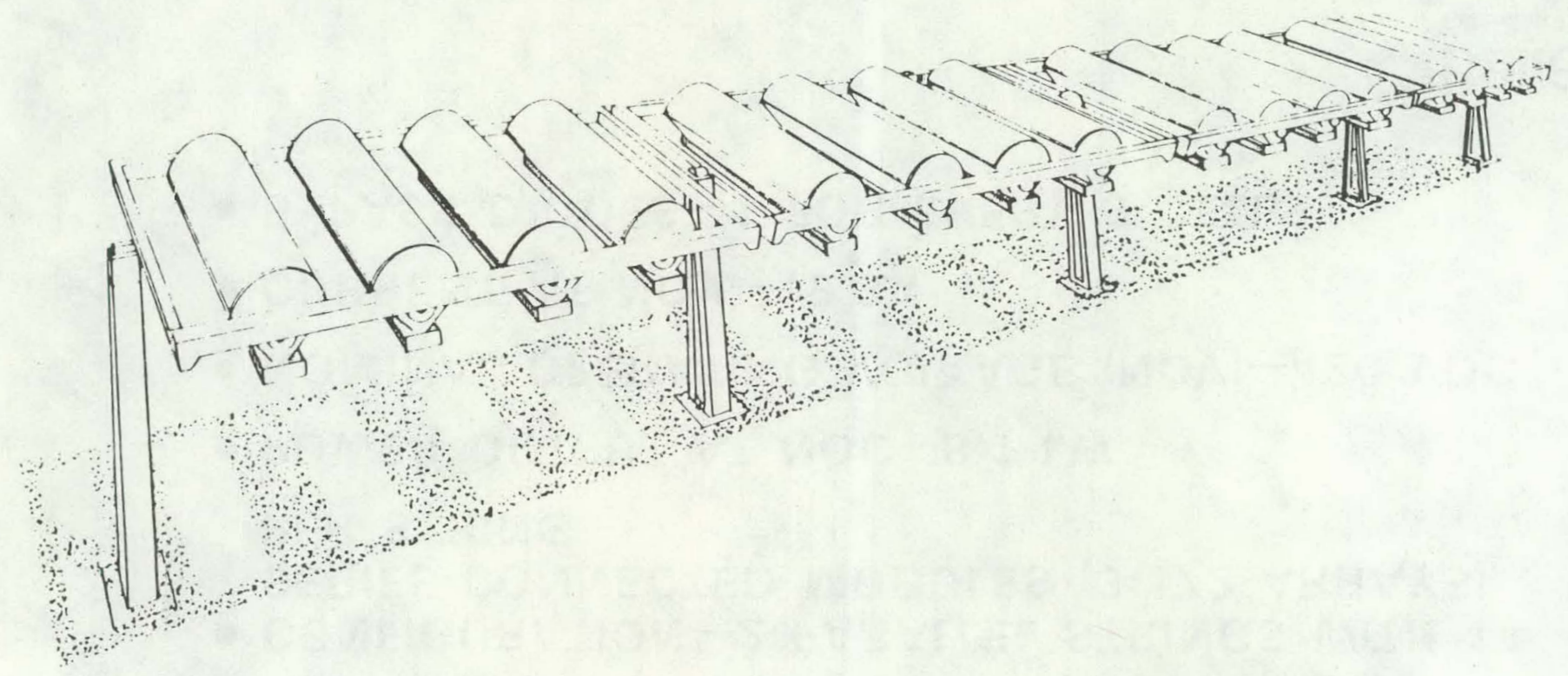

E-SYSTEMS

PHOTOVOLTAIC CONCENTRATOR

DESIGN 


\section{RECOMMENDED BUILDING BLOCK CONFIGURATION-E-SYSTEMS}

- NUMBER OF MODULES-28

- NUMBER OF ARRAYS (4 MODULES/ARRAY)-7

- CONFIgURATION-2 PARALLEL STRINGS WITH 14 SERIES-CONNECTED MODULES (3-1/2 ARRAYS) PER STRING

- POWER OUTPUT AT NOC-8.1 kW

- NOMINAL OPERATING VOLTAGE (NOV)-420 VDC

- CURRENT AT NOV-19.3A

- BYPASS DIODES-1 FOR EVERY 9 CELLS 


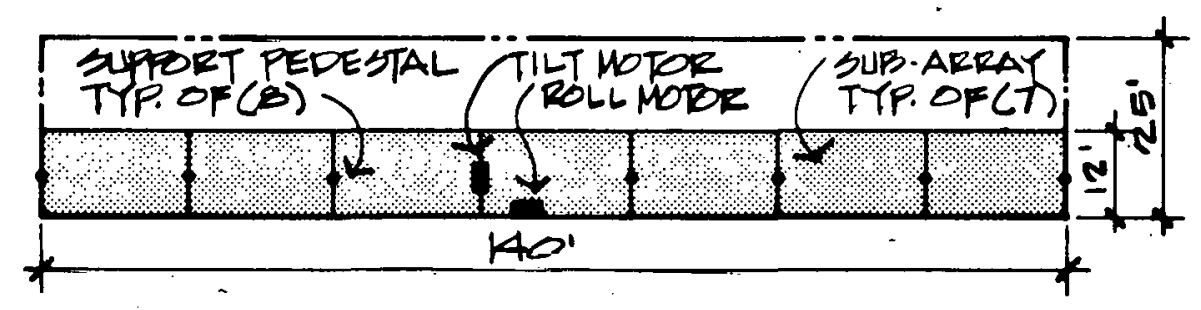

E-SYSTEMS TWO AXIS TRACKING CONCENTRATOR BUILDING BLOCK CONCEPT 8.12KW 420VDC $\begin{array}{llll}0 & 10^{\prime} & 20^{\prime} & 40^{\prime}\end{array}$ 801 


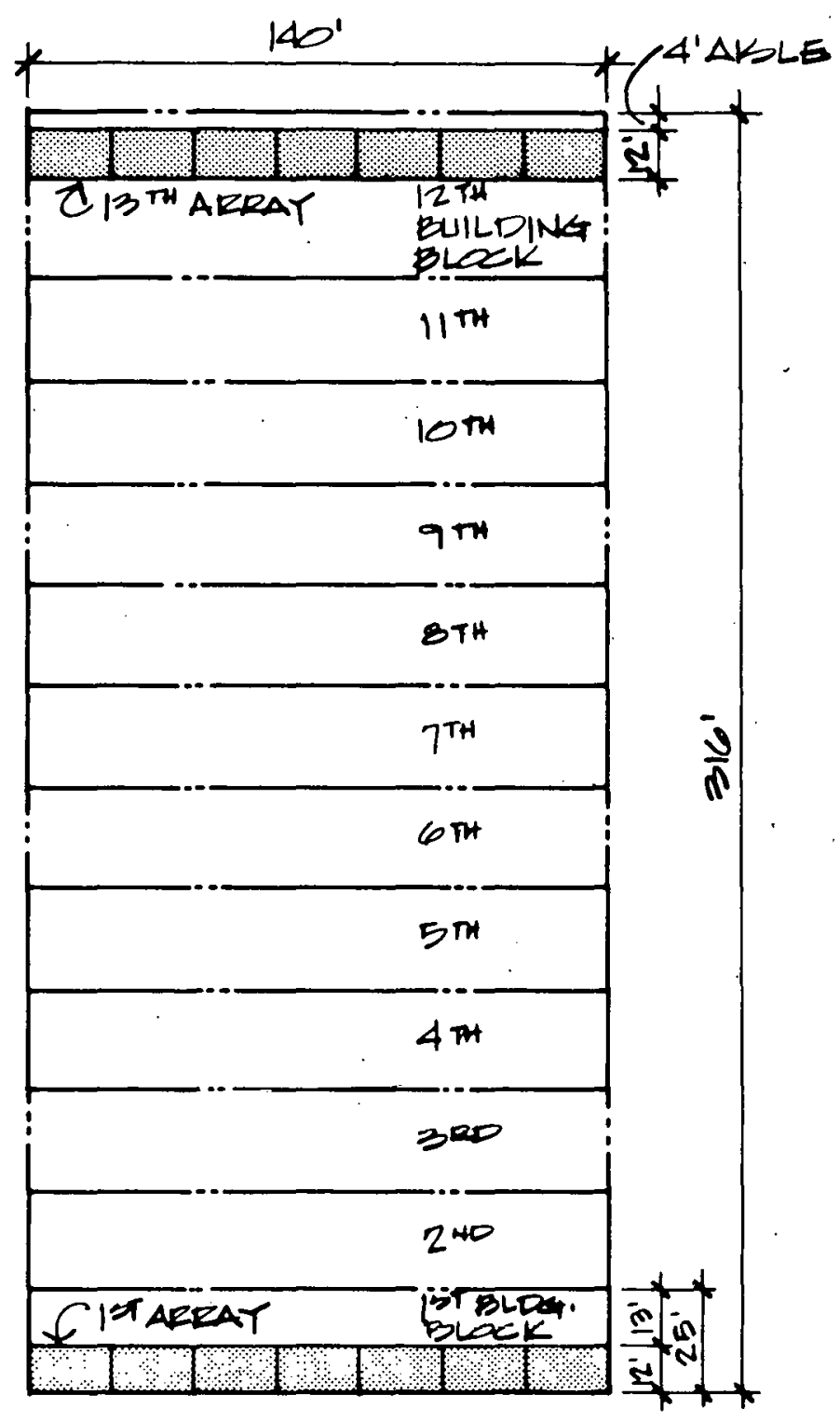

\section{E-SYSTEMS TWO AXIS TRACKING CONCENTRATOR 10OKW ARRAY FIELD PLAN $010^{\prime} 20^{\prime} \quad 50^{\prime} \quad 100^{\prime}$

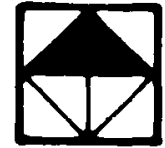




\section{STRUCTURE \\ E-SYSTEMS PHOTOVOLTAIC CONCENTRATOR ONE BUILDING BLOCK}

PHYSICAL REQUIREMENTS

PIER DESIGN:

- REINFORCED CONCRETE

- 4-BOLT PATTERN

- FLUSH WITH GROUND SURFACE

PIER PLACEMENT:

- 8 PIERS SET WITHIN:

$\pm 1 / 4$ INCH VERTICALLY

$\pm 1 / 2^{\circ}$. TRUE EAST TO WEST

$\pm 1 / 8$-INCH COLLINEAR

SUBSURFACE:

- 20-INCH DIAMETER PIERS SET TO MINIMUM 5-FOOT DEPTH (DETERMINED BY SOIL TESTS!

CONCRETE:

- 3.23 YD $^{3}$ MINIMUM/BUILDING BLOCK

\section{CAPABILITIES:}

WIND:

- DRIVE TO STOW AT 30-38 MPH

- SURVIVES $60 \mathrm{MPH}$ DURING STOW

- SURVIVES 90 MPH STOWED

TEMPERATURE:

- OPERATIONAL - $20^{\circ}$ TO $+120^{\circ} \mathrm{F}$

- SURVIVES $-40^{\circ}$ TO $+140^{\circ} \mathrm{F}$

RATED OUTPUT:

- 8.12 KW AT 420 VDC 


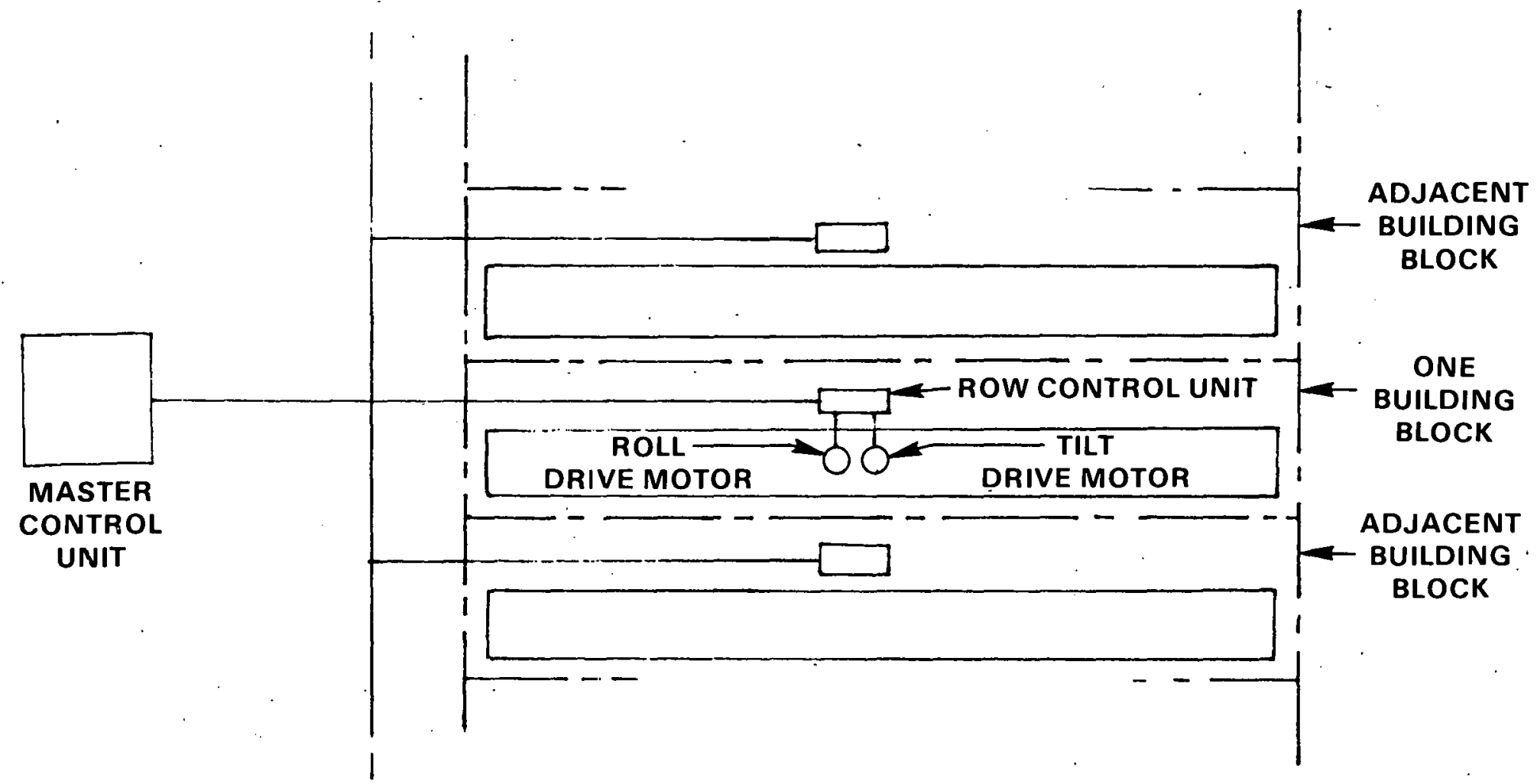

E-SYSTEMS

CONTROL SYSTEM 


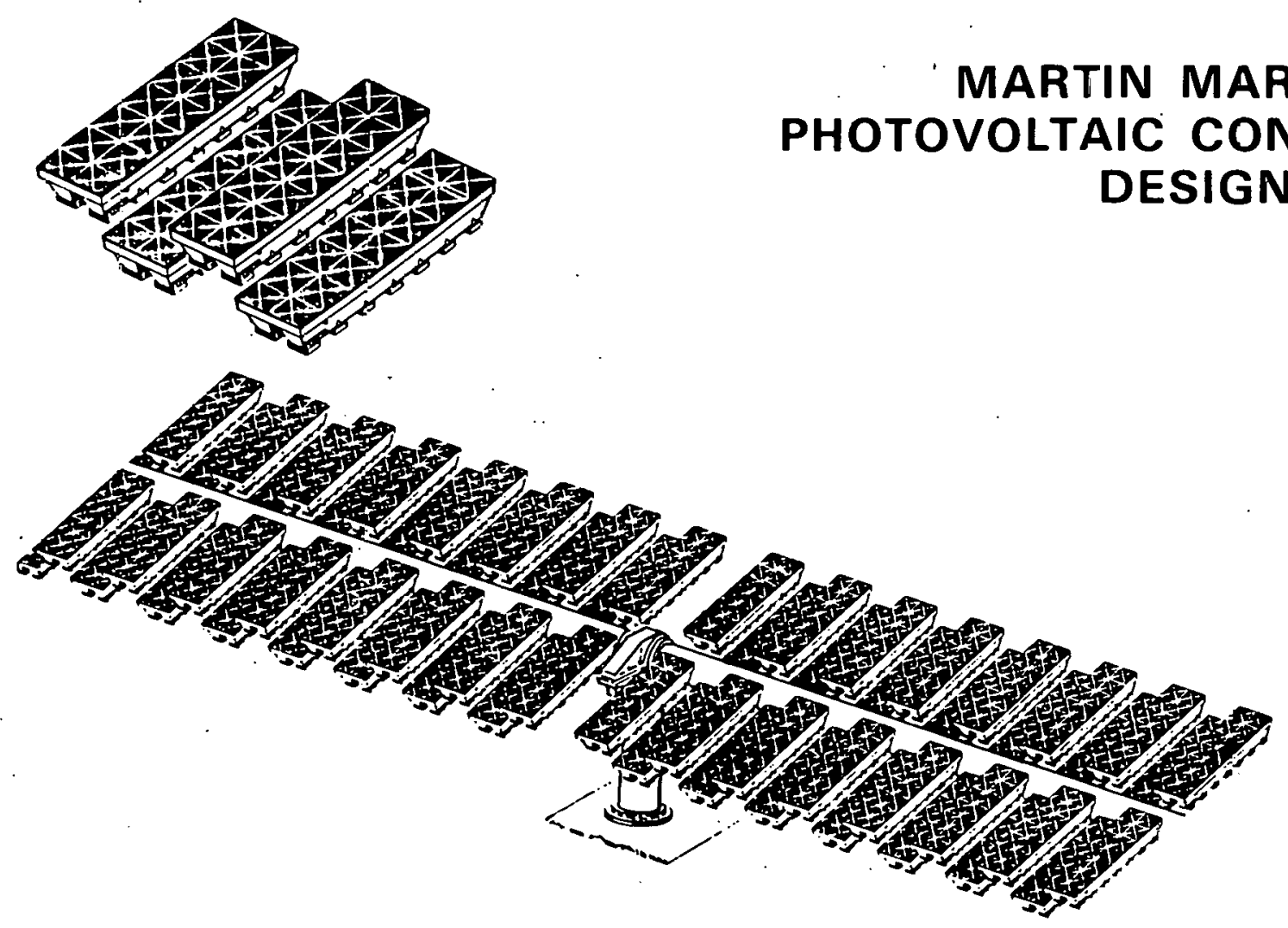




\section{RECOMMENDED BUILDING BLOCK CONFIGURATION-MARTIN MARIETTA}

- NUMBER OF MODULES-180

- NUMBER OF ARRAYS (60 MODULES/ARRAY)-3

- CONFIgURATION-3 PARALLEL-CONNECTED ARRAYS

- POWER OUTPUT AT NOC-11.1 kW

- NOMINAL OPERATING VOLTAGE-420 VDC

- CURRENT AT NOV-26.4A

- BYPASS DIODES-1 FOR EVERY 14 CELLS 


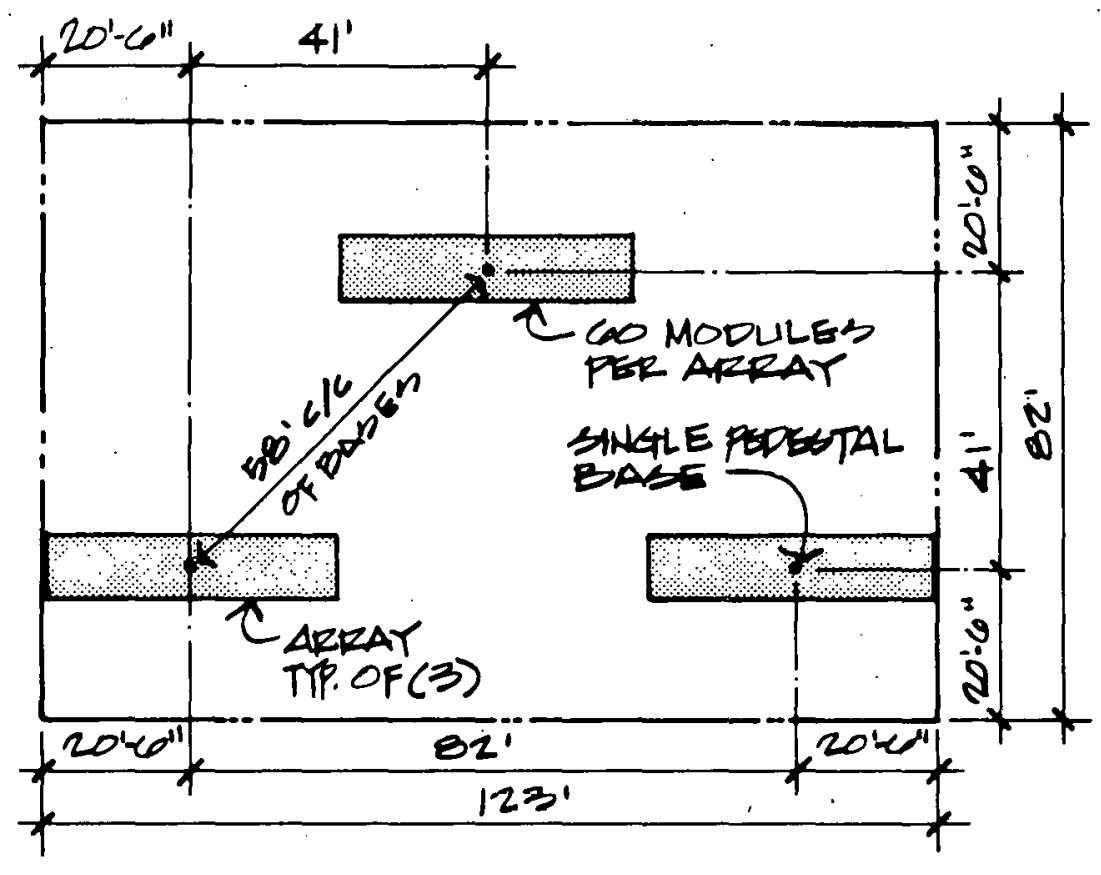

MARTIN-MARIETTA TWO AXIS TRACKING CONCENTRATOR BUILDING BLOCK CONCEPT

11.09KW 420VDC

\begin{tabular}{llll}
0 & $10^{\prime}$ & $20^{\prime}$ & $40^{\prime}$ \\
\hline & & &
\end{tabular} 80

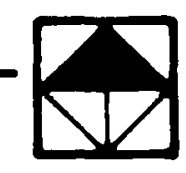




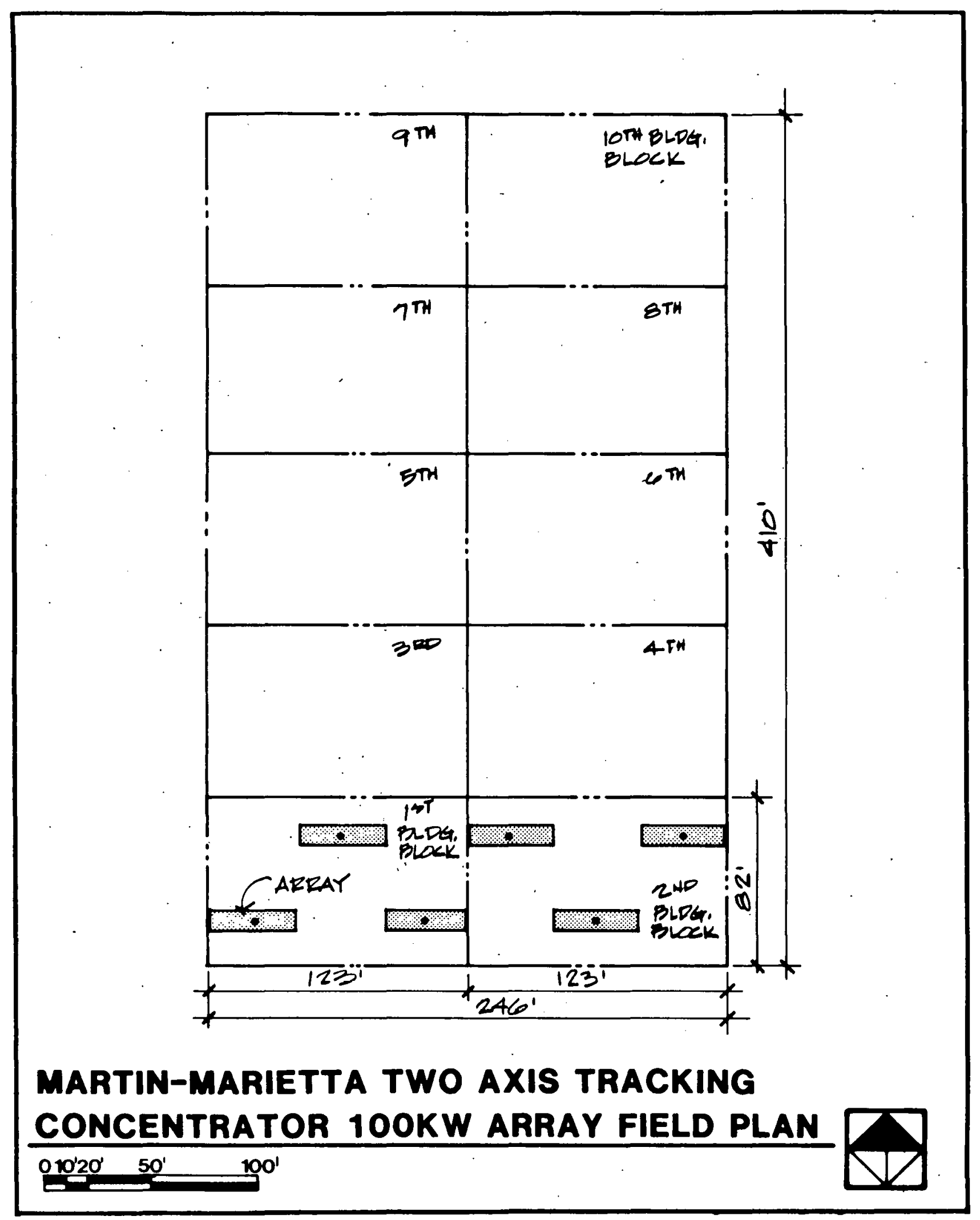




\section{STRUCTURE}

\section{MARTIN MARIETTA PHOTOVOLTAIC CONCENTRATOR}

ONE BUILDING BLOCK

\section{PHYSICAL REQUIREMENTS}

PIER DESIGN:

- REINFORCED CONCRETE

- 6-Bolt pattern

- FORMED IN CARDBOARD TO 6 FEET ABOVE GROUND

PIER PLACEMENT:

- 3 INDEPENDENT FIERS/BUILDING BLOCK

- MINOR PLACEMENT VARIATIONS NOT CRITICAL UNLESS SHADING OCCURS

SUBSURFACE:

- 18-INCH DIAMETER PIERS SET 6-12 FEET DEEP (DETERMINED BY SOIL TESTS)

CONCRETE:

- 2.36 YD $^{3}$ MINIMUM/BUILDING BLOCK

\section{CAPABILITIES}

WIND:

- DRIVE TO STOW AT 26-30 MPH

- SURVIVES 50 MPH DURING STOW

- SURVIVES $100 \mathrm{MPH}$ AT $10^{\circ}$ INCLINATION

TEMPERATURE:

- NOT STATED

RATED OUTPUT:

- $11.09 \mathrm{~kW}$ AT $420 \mathrm{VDC}$ 


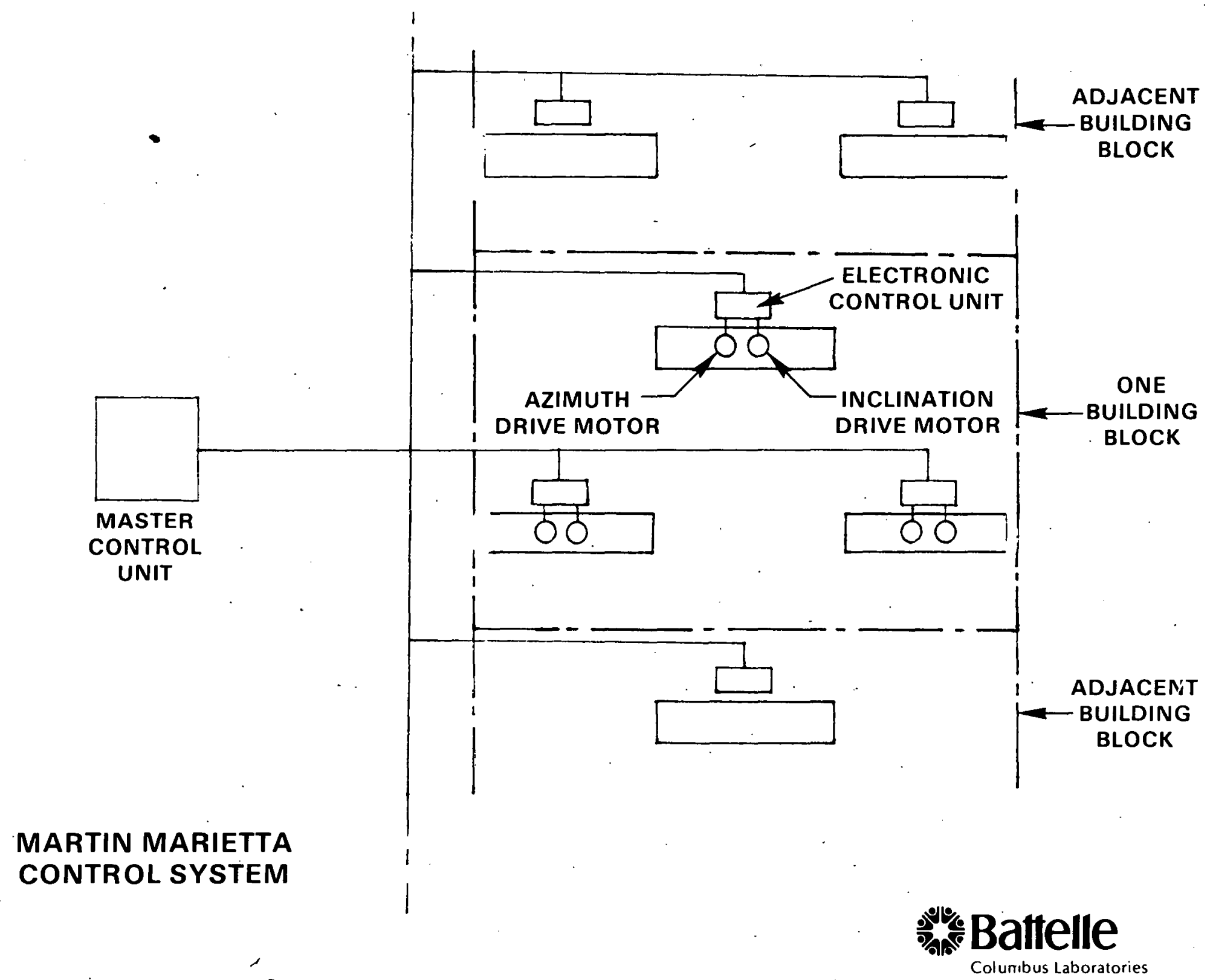

Columibus Laboratories 
by

H. A. FRANKL IN

Bechtel Group, Inc.

50 Beale Street

San Francisco, California 94105

\begin{abstract}
Support structures for photovoltaic arrays are a significant cost component in photovoltaic central power plants. Thus, the major objective of this study was to develop low-cost, integrated designs for flat panel, ground-mounted support structures. Available concepts were reviewed and new ones proposed for further cost reductions. Based on preliminary cost estimates, two candidate support concepts were selected which showed the most promise of achieving low cost. The two candidate support concepts included structural steel support frames having either wood pole or concrete calsson foundations.
\end{abstract}

Design criteria for a site location was developed and dynamic effects due to fluctuating winds were estimated. This was a necessary step since structural support cost is largely determined by the assumptions made in the design criteria. Wind load is significant in the design of array support structures and is characterized by a great uncertainty in the determination of actual magnitudes of wind velocities and forces. A series of wind-tunnel tests were conducted to determine the effects of various design parameters on wind loadings for different wind directions on a single array and also on individual arrays at different locations in a large array field.

It was found that wind forces on the interior of a large array field can be $63 \%$ lower than those on its perimeter. The introduction of fences reduces the loadings on the perimeter arrays approximately $54 \%$ while only slightly increasing the loadings on some of the interior arrays. However, the use of fences was not found to be economically feasible.

Span lengths of the support structures were varied to achieved an optimized design. Final array designs consisted of a $8^{\prime} \times 36^{\prime}$ steel panel frame supported at both ends by either wood pole or concrete caisson foundations.

Installed direct costs in mid - 1981 dollars based on a $10 \mathrm{MW}$ array field size were $\$ 34.80 / \mathrm{m}^{2}$ for the structure having wood pole foundations and $\$ 34.00 / \mathrm{m}^{2}$ for the structure having concrete caisson foundations. Using these designs, the construction of a small, non-working array field is being planned for Albuquerque in early 1982. 
(ARRANGED IN ORDER OF INCREASING COSTS)

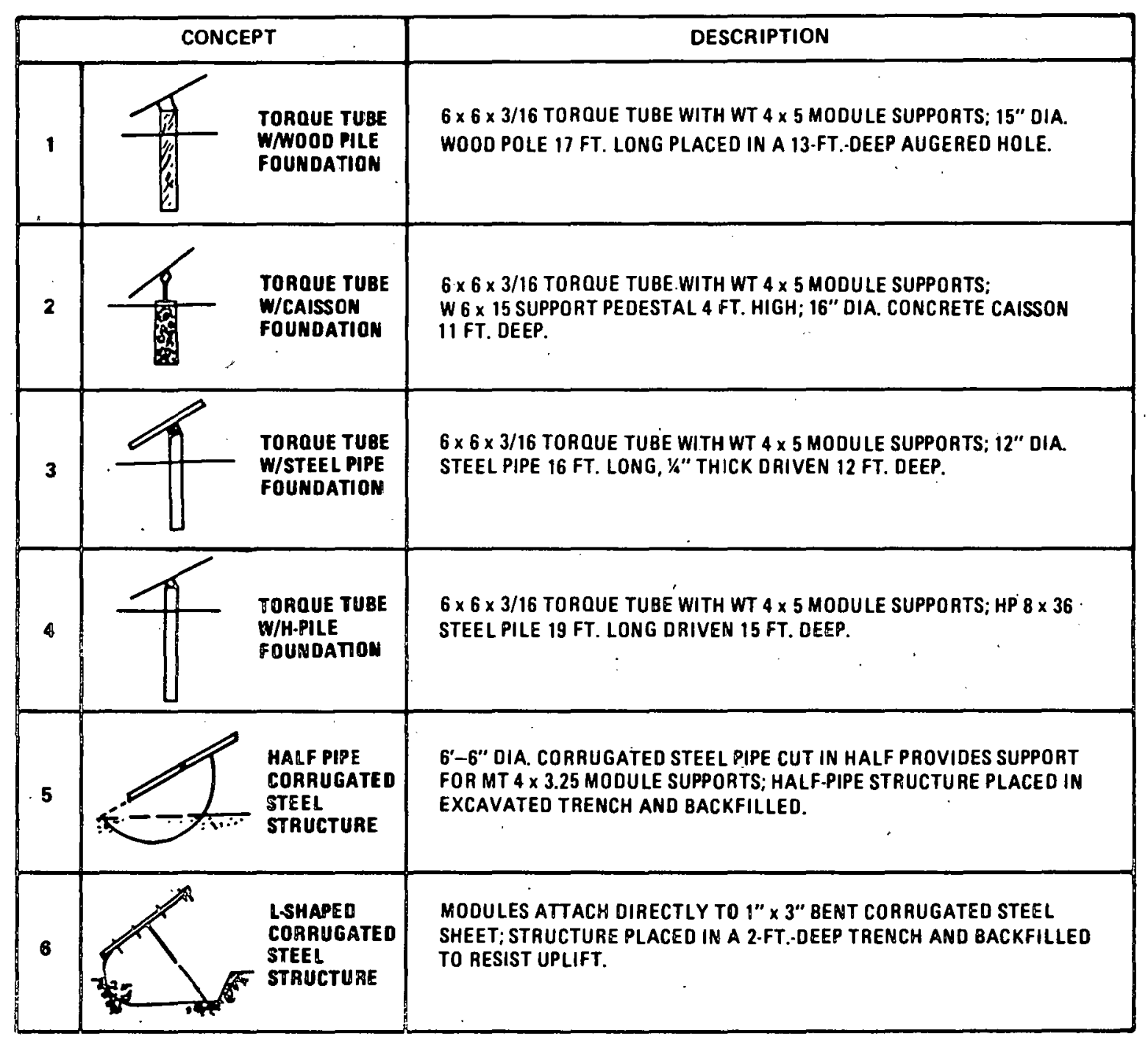




\section{FINAL ARRAY DESIGN CONSIDERATIONS}

- IMPROVE STRUCTURAL. DES IGN CR ITER IA BY EXAM INING:

- LOAD FACTORS

- FOUNDATION SAFETY FACTORS

- FOUNDATION DESIGN METHODS

- USE OF WIND TUNNEL TEST RESULTS TO DETERMINE DES IGN WIND LOADS

- DYNAMIC ANALYSIS OF STRUCTURE TO DETERMINE TURBULENCE FACTOR K

- DOUBLE-POST ARRAY DES IGN TO ELIMINATE TOKSION ON FOUNDATIONS

- VARIATIONS OF ARRAY SPAN LENGTHS TO OPTI MIZE STRUCTURE AND LOWER TOTAL COSTS 


\section{RESULTANT ARRAY FORCES}

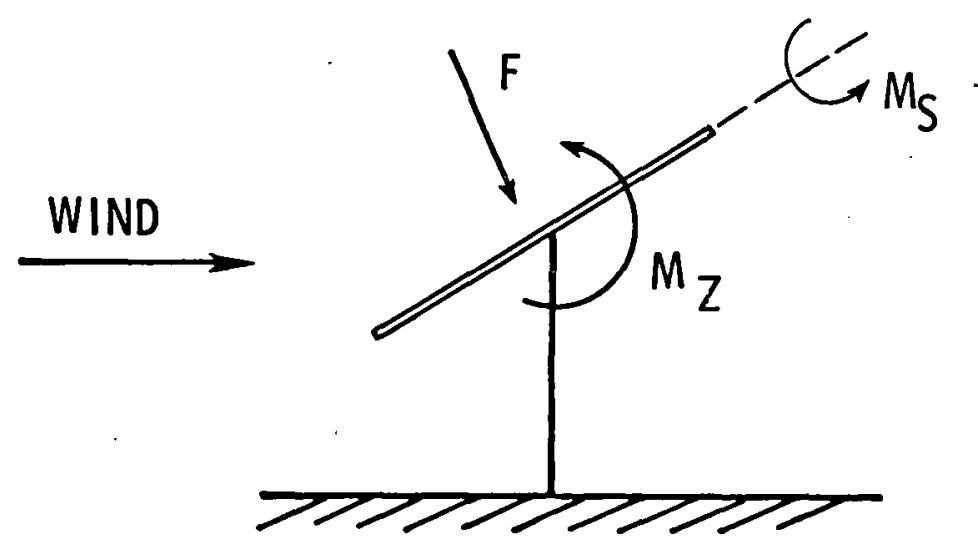

$A=$ PANEL AKEA

$D=$ PANEL CHORD DISTANCE

NORMAL FORCE $F=K \cdot q \cdot C_{N} \cdot A$

PITCHING MOMENT $M_{Z}=K \cdot q \cdot C_{M Z} \cdot A \cdot D$

YAWING MOMENT $M_{S}=K \cdot q \cdot C_{M S} \cdot A \cdot D$

$C_{N}, C_{M Z}$, AND $C_{M S}$ DER IVED FR OM WIND TUNNEL TESTS

$K$ IS DYNAMIC TURBULENCE FACTOR 
- $\quad$ ARRAY DES IGN WIND LOADS FOR INTERIOR ARRAYS AS LOW AS 30\% OF UBC WIND LOADS

- SIGNIFICANT YAWING MOMENTS ON SINGLE-POST ARRAY DESIGN

- FENCES REDUCE LOADS ONLY ON EXTERIOR ARRAYS (COST ANALYSES SHOW FENCES ARE NOT ECONOMIC)

- INTERIOR ARRAYS PROTECTED BY EXTERIOR ARRAYS

- FORCE COEFFICIENT $C_{N}-0.8$ EXTERIOR ARRAYS

-0.3 INTER IOR ARRAYS 


\section{DYNANIC ANALYSIS OF ARRAY STRUCTURE}

\section{APPROACH}

- EVALUATION OF RESPONSE TO FLUCTUATING WIND LOADS

- WIND LOADS DEFINED BY POWER S PECTRAL DENS ITY (PSD) FUNCTIONS GENERATED FF OM BOEING/CSU WIND TUNNEL TESTS

- FINITE ELEMENT MODELS OF STRUCTUKES CREATED AND MODAL FKEQUENC IES AND SHAPES EXTRACTED

RESULTS

- NATURAL FREQUENCIES - 6.6 cPS FOR SINGLE-POST DESIGN

$\rightarrow 10$ CPS FOR DOUBLE-POST DES IGN

- DYNAMIC TURBULENCE FACTORS:

$K=3$ FOR SINGLE-POST DESIGN

$K=2$ FOR DOUBLE-POST DESIGN 


\section{䨘 DESIGN ASSUMPTIONS FOR 10 MW ARRAY FIELD}

- $4^{\prime} \times 4^{\prime}$ FRAMED PHOTOVOLTAIC MODULES

- 8' PANEL WIDTHS

- 90 MPH DES IGN WIND SPEED

- aRRAY DES IGNED AS AN INTERIOR ARRAY

- FORCE COEFFIC IENTS:

$$
\begin{aligned}
& C_{N}=0.30 \\
& C_{M S}=0.28 \\
& C_{M Z}=0.04
\end{aligned}
$$

- DYNAMIC TURBULENCE FACTOR $K=2$ 


\section{SELECTED ARRAY SUPPORT CONCEPT}

(8' $\times 36^{\prime}$ 'SIZE ARRAYS ATTACHED TO EXTENDED CONCRETE CAISSONS)

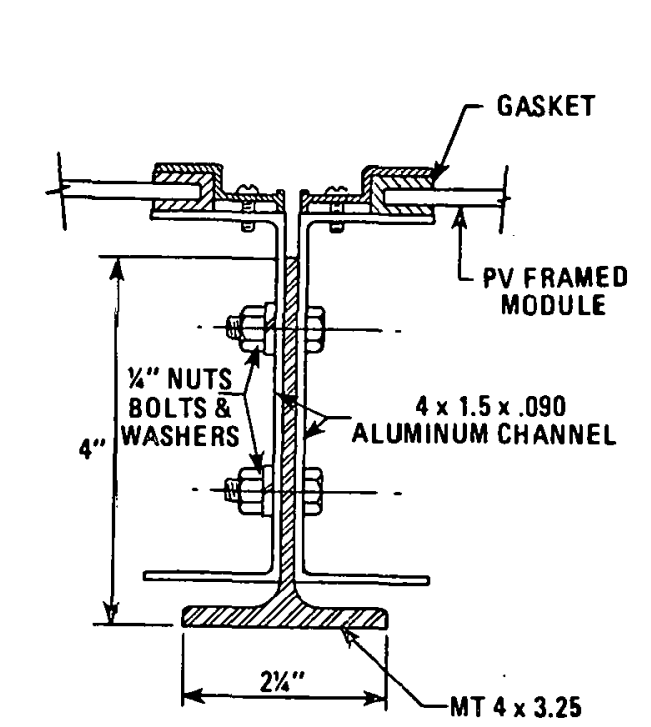

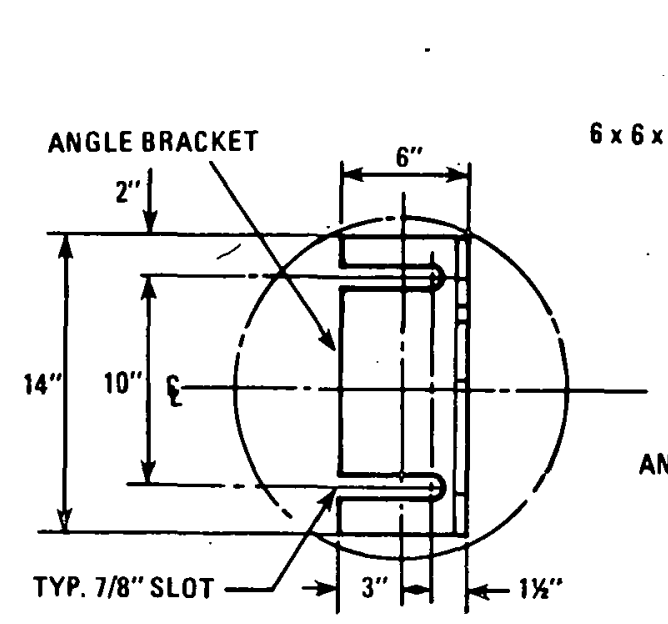

(a) PLAN VIEW

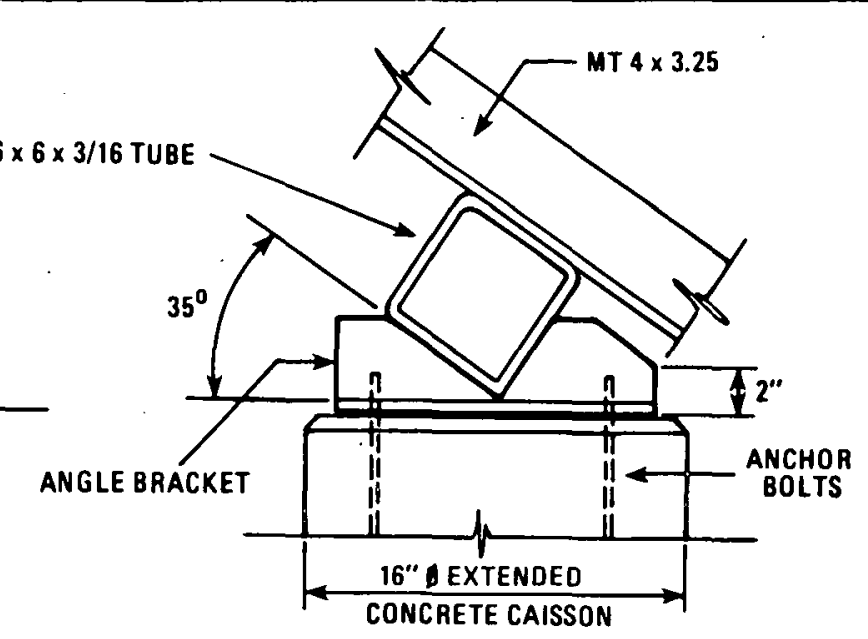

(b) ELEVATION

SECTION THRU' PANEL

SUPPORTING STRUCTURE CONNECTION OF FRAME TO CAISSON FOUNDATION

4' $\times$ 4' FRAMED MODULE
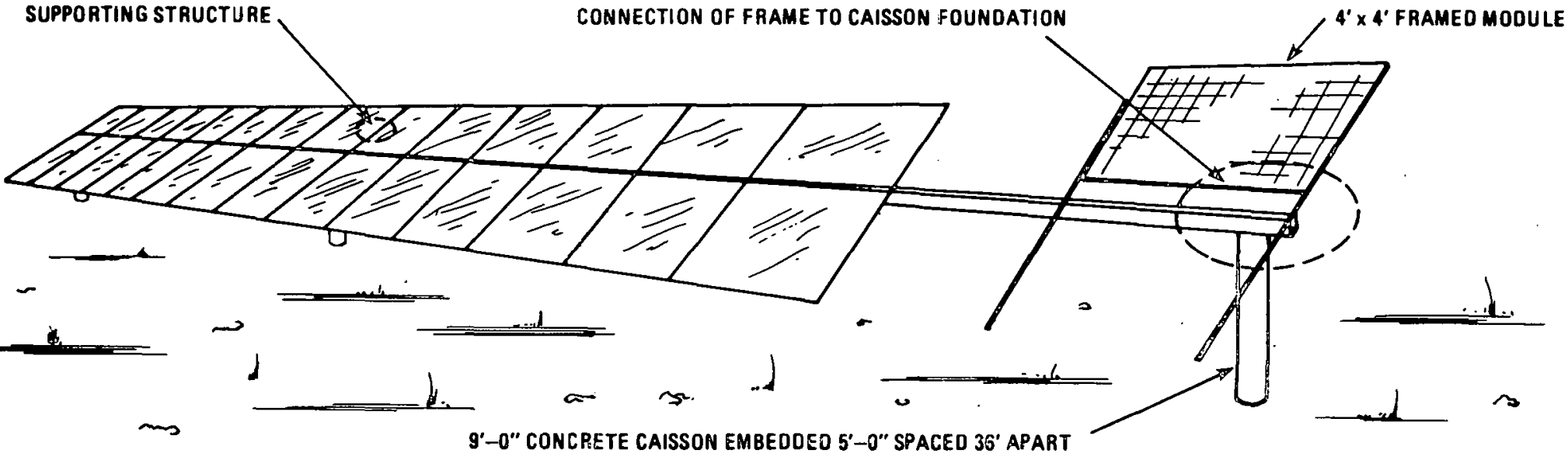

9'-0" CONCRETE CAISSON EMBEDOEO 5'-0" SPACED 35' APART 


\section{TOTAL INSTALLED DIRECT COSTS IN $\$ / \mathrm{M}^{2}$}

(BASED ON 10 MW FIELD SIZE AND MID-1981 \$)

$\begin{array}{ccc}\text { ARRAY SIZE } & \begin{array}{c}\text { EXTENDED } \\ \text { CONCRETE CAISSON }\end{array} & \begin{array}{c}\text { TIMBER } \\ \text { POLE SUPPORT }\end{array} \\ 8^{\prime} \times 20^{\prime} & 37.30 & 38.40 \\ 8^{\prime} \times 32^{\prime} & 35.30 & 36.20 \\ 8^{\prime} \times 36^{\prime} & 34.00 & 34.80 \\ 8^{\prime} \times 40^{\prime} & 35.30 & 36.20\end{array}$




\section{UNIT COST BREAKDOWN FOR $8^{\prime} \times 36^{\prime}$ ARRAY SIZE}

(BASED ON 10 MW FIELD SIZE AND MID-1981 \$)

\begin{tabular}{|c|c|c|c|c|}
\hline \multirow[t]{2}{*}{ COST ELEMENTS } & \multicolumn{2}{|c|}{$\begin{array}{c}\text { EXTENDED } \\
\text { CONCRETE CAISSON } \\
\end{array}$} & \multicolumn{2}{|c|}{$\begin{array}{c}\text { TIMBER } \\
\text { POLE SUPPORT } \\
\end{array}$} \\
\hline & $\$ \operatorname{COST}$ & $\$ 1 m^{2}$ & $\$ \operatorname{COST}$ & $\$ 1 \mathrm{~m}^{2}$ \\
\hline PANEL F. O. B. JOBS ITE & 540 & 20.20 & 540 & 20.20 \\
\hline PANEL INSTALLATION & 90 & 3.40 & 90 & 3. 40 \\
\hline MODULE INSTALLATION & 100 & 3.70 & 100 & 3.70 \\
\hline STRUCTURAL CONNECTION & 45 & 1.70 & 75 & 2.80 \\
\hline INSTALLED FOUNDATION & 135 & 5.00 & 125 & 4.70 \\
\hline TOTAL INSTALLED DIRECT COSTS & 910 & 34.00 & 930 & 34.80 \\
\hline
\end{tabular}


AUTOMATED METHODS FOR THE INSTALLATION

OF LARGE PHOTOVOLTAIC ARRAYS

John R. Oster, Jr.

Burt Hill Kosar Rittelmann Associates

400 Morgan Center

Butler, Pennsylvania 16001

A substantial portion of the cost of a large photovoltaic power system will be attributed to the cost of installation. For this study, the installation of the photovoltaic arrays will include all areas, starting with site preparation, and concluding with the termination of the bus at the power conditioner building. Trenching, wiring, run-off, foundation installation, lightning protection, grounding and the installation of the panel are all areas which fall under the array installation umbrella. As these costs can amount to one-quarter to one-half of the overall installed system cost, methods for reducing these costs have been investigated.

There is a wide range of installation possibilities ranging from standard installation practices, common to the building industry, to totally automated installation methods. The identification of the optimum mix of standard installation procedures and automated/mechanized techniques requires the investigation and evaluation of the installation process steps; the equipment and hardware available for each step; the photovoltaic array structural systems and interfaces; and the array field and site characteristics.

This study investigated both the standard installation methods and the automated/mechanized methods which were felt capable of reducing the overall installation cost of large photovoltaic arrays. Preliminary designs of hardware for the methods identified as appropriate for automation/mechanization were performed. A mix of standard installation procedures and mechanized procedures was identified. In addition, costs associated with each type of installation method and the costs associated with the design, development and fabrication of new installation hardware were generated.

The draft final report is underway, and pending a review, the delivery of the final report for publication is expected in late March. 


\section{AUTOMATED INSTALLATION METHODS PROJECT}

ARRAY FIELD CHARACTERISTICS

\begin{tabular}{|c|c|c|}
\hline ARRAY TYPE & FLAT PLATE & POINT FOCUS FRESNEL LENS \\
\hline SUPPORT STRUCTURE & $\begin{array}{l}\text { TORQUE · TUBE } \\
\text { SINGLE SUPPORT } \\
\text { WOOD PILE OR CONCRETE }\end{array}$ & $\begin{array}{l}\text { TORQUE TUBE } \\
\text { SINGLE SUPPORT } \\
\text { CONCRETE }\end{array}$ \\
\hline ARRAY EFFICIENCY & $10 \%$ & $12.5 \%$ \\
\hline ARRAY FIELD OUTPUT & $10 \mathrm{MW}_{\mathrm{P}}$ & $10 \mathrm{MW}_{\mathrm{P}}$ \\
\hline ARRAY FIELD AREA & 90 ACRES & 257 ACRES \\
\hline PANEL/ARRAY AREA & $8^{\prime} \times 20^{\prime}$ & $8^{\prime} \times 42^{\prime}$ \\
\hline PANEL/ARRAY OUTPUT & $1485 \mathrm{~W}_{\mathrm{P}}$ & $3155 \mathrm{w}_{\mathrm{P}}$ \\
\hline BRANCH CIRCUIT & $+1000 \mathrm{~V}_{\mathrm{DC}}-\mathrm{GND}-\left(-1000 \mathrm{~V}_{\mathrm{DC}}\right)$ & $+1026 \mathrm{~V}_{\mathrm{DC}}-\mathrm{GND}-\left(-1026 \mathrm{v}_{\mathrm{DC}}\right)$ \\
\hline BUS WIRING & IN GROUND & IN GROUND \\
\hline PANEL TO PANEL WIRING & TORQUE TUBE RACEWAY & \\
\hline ARRAY TO ARRAY WIRING & & IN GROUND \\
\hline
\end{tabular}




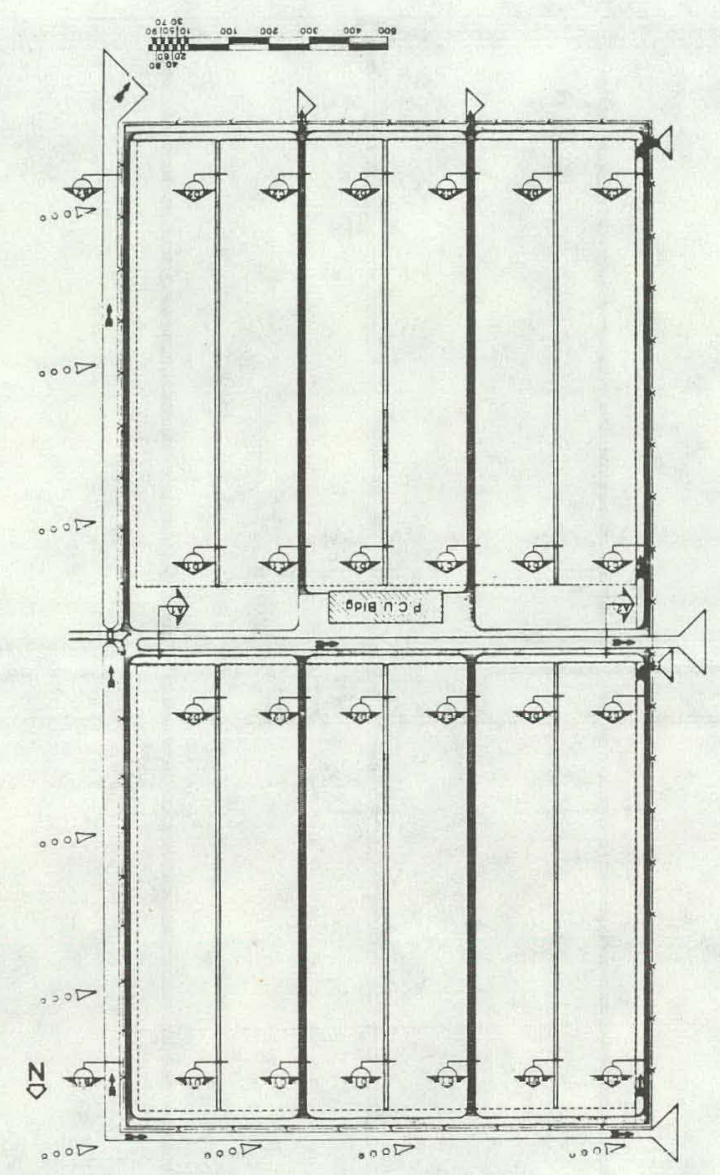

183 


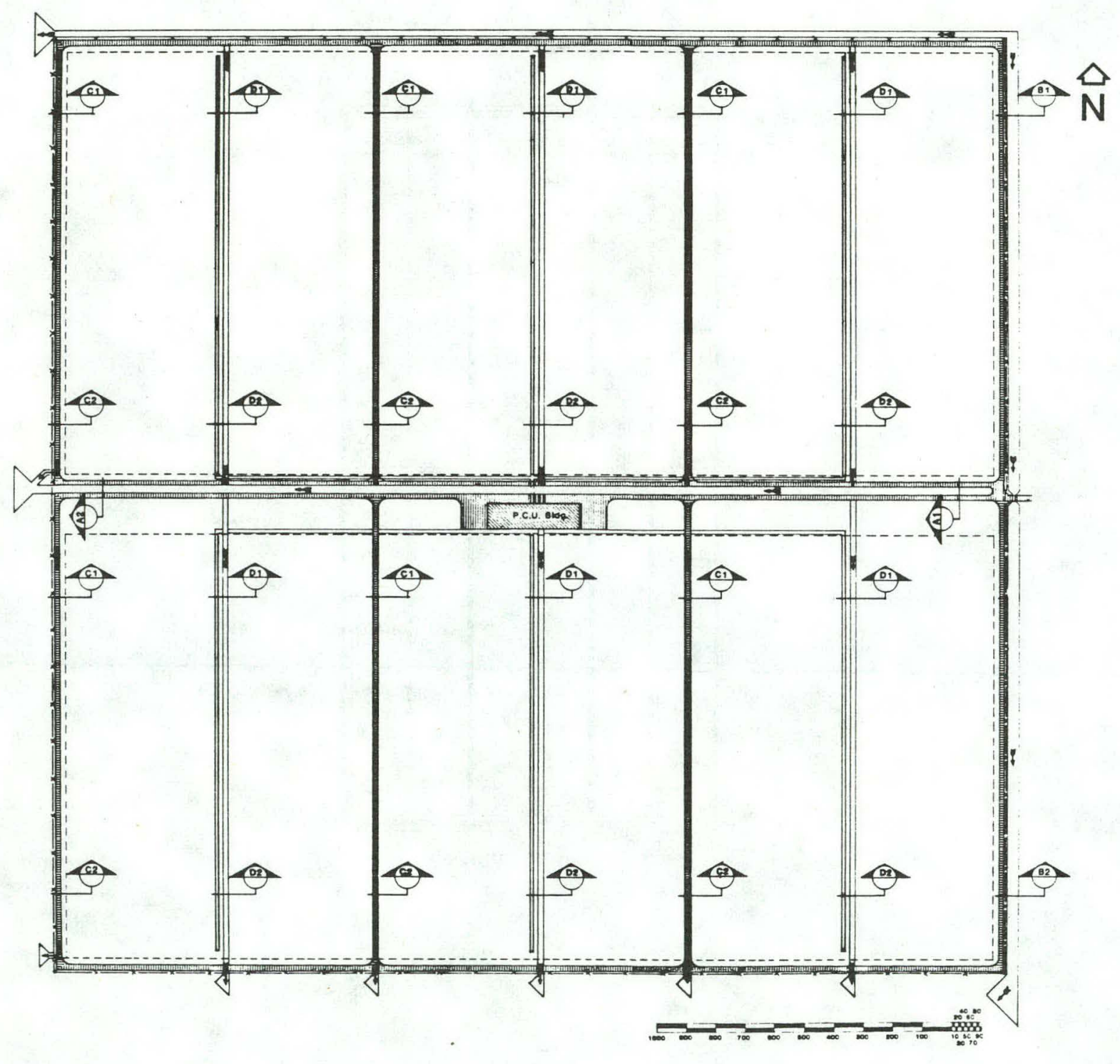



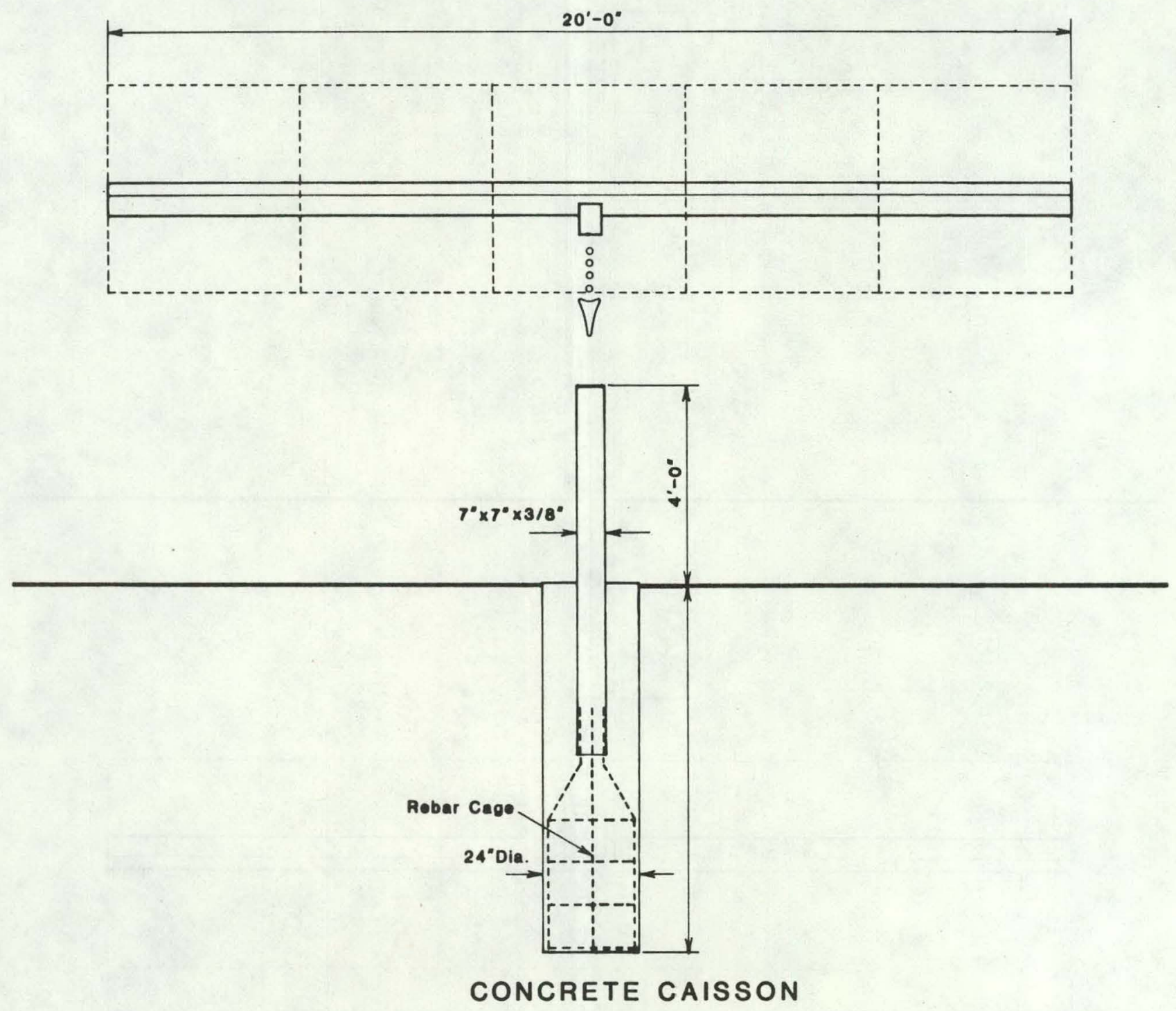


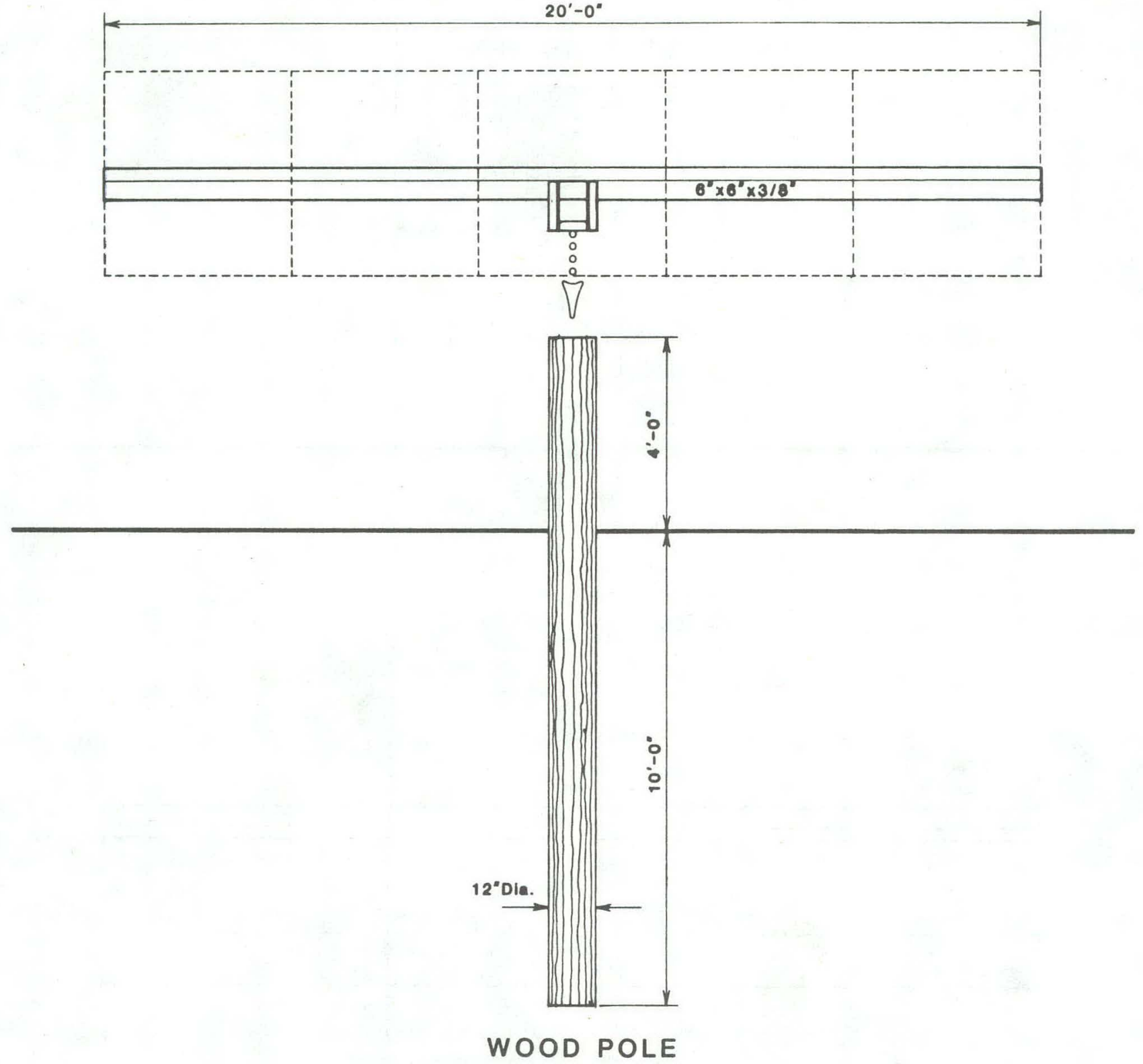




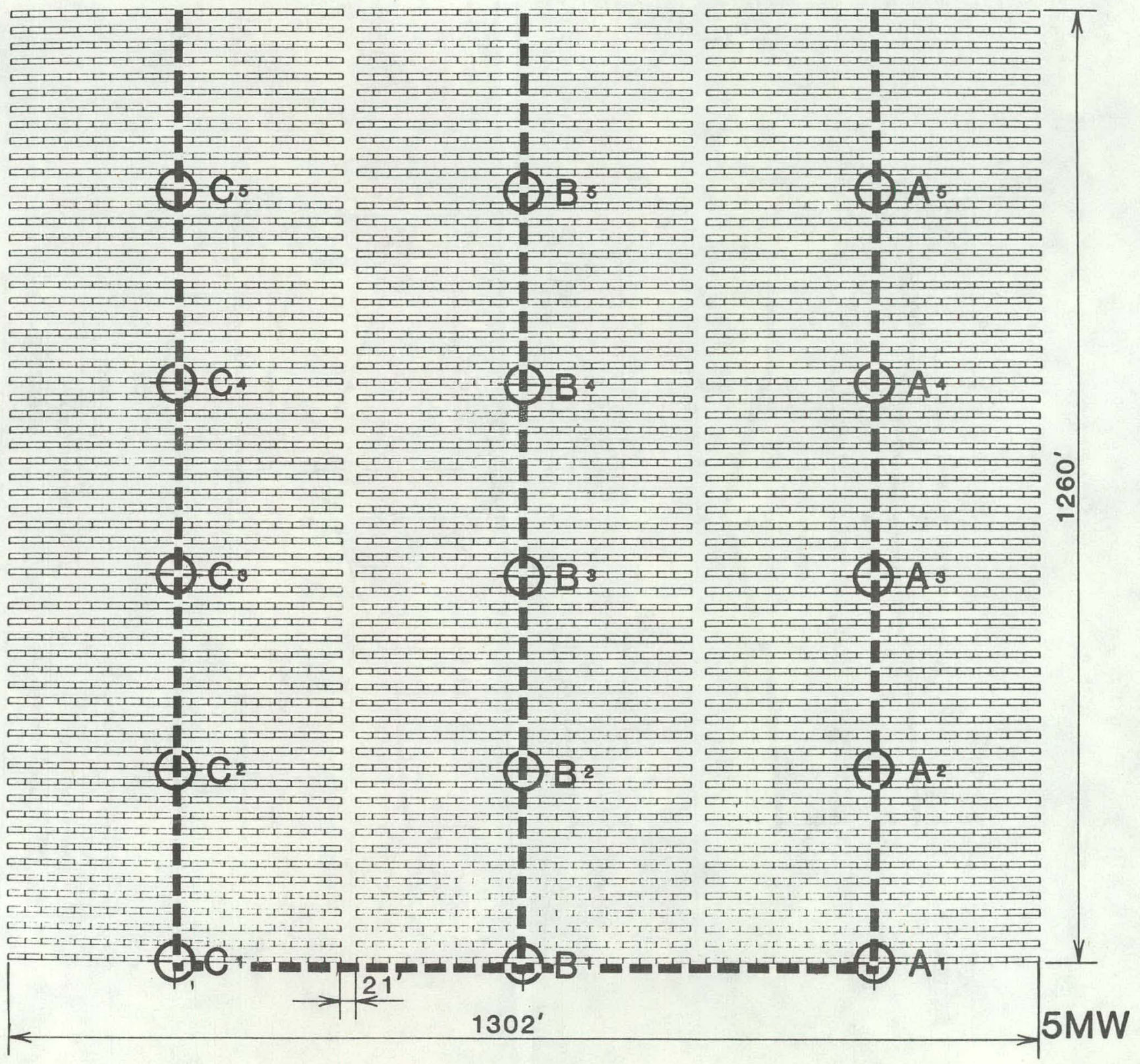



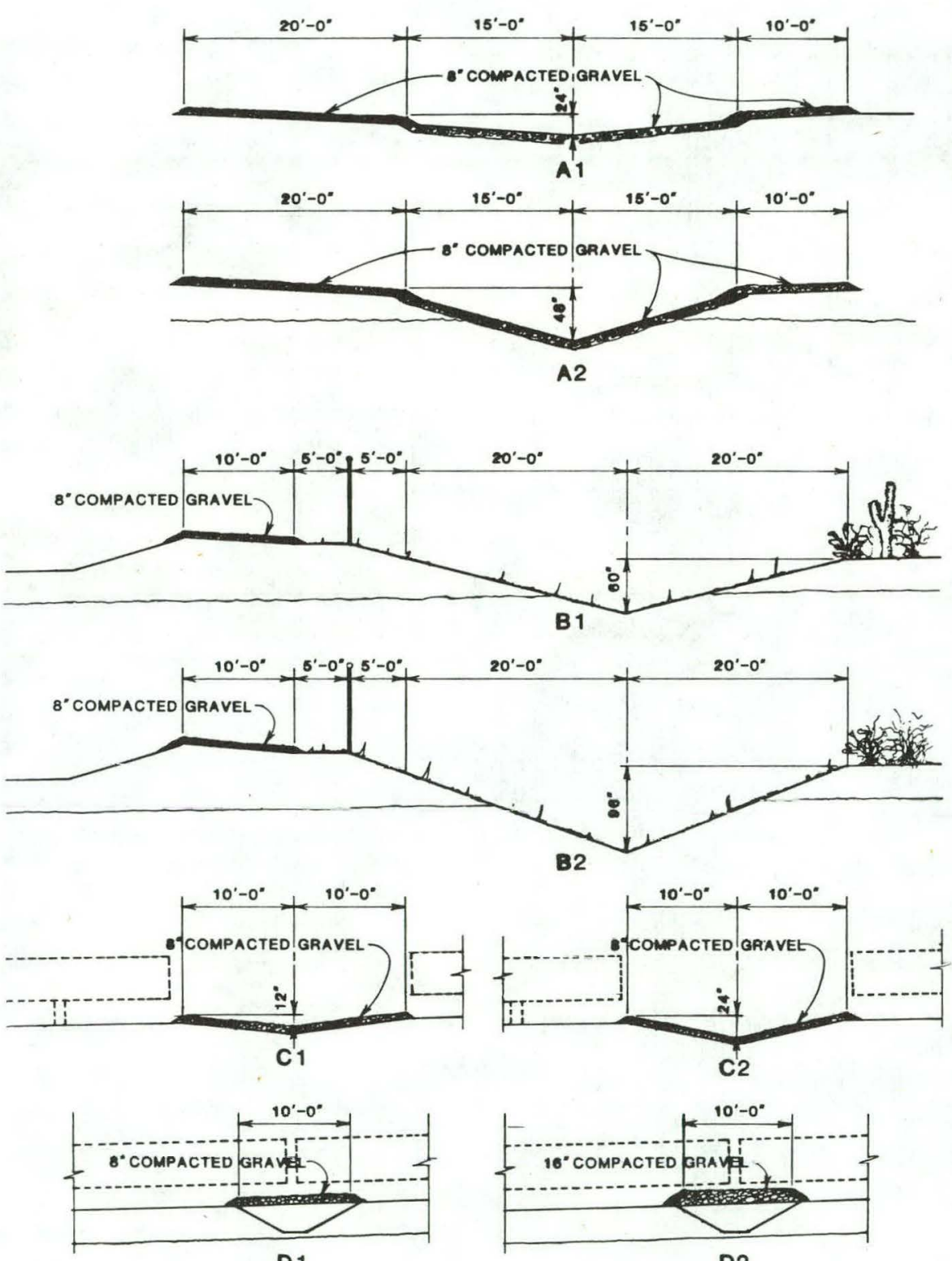

D1

D2 


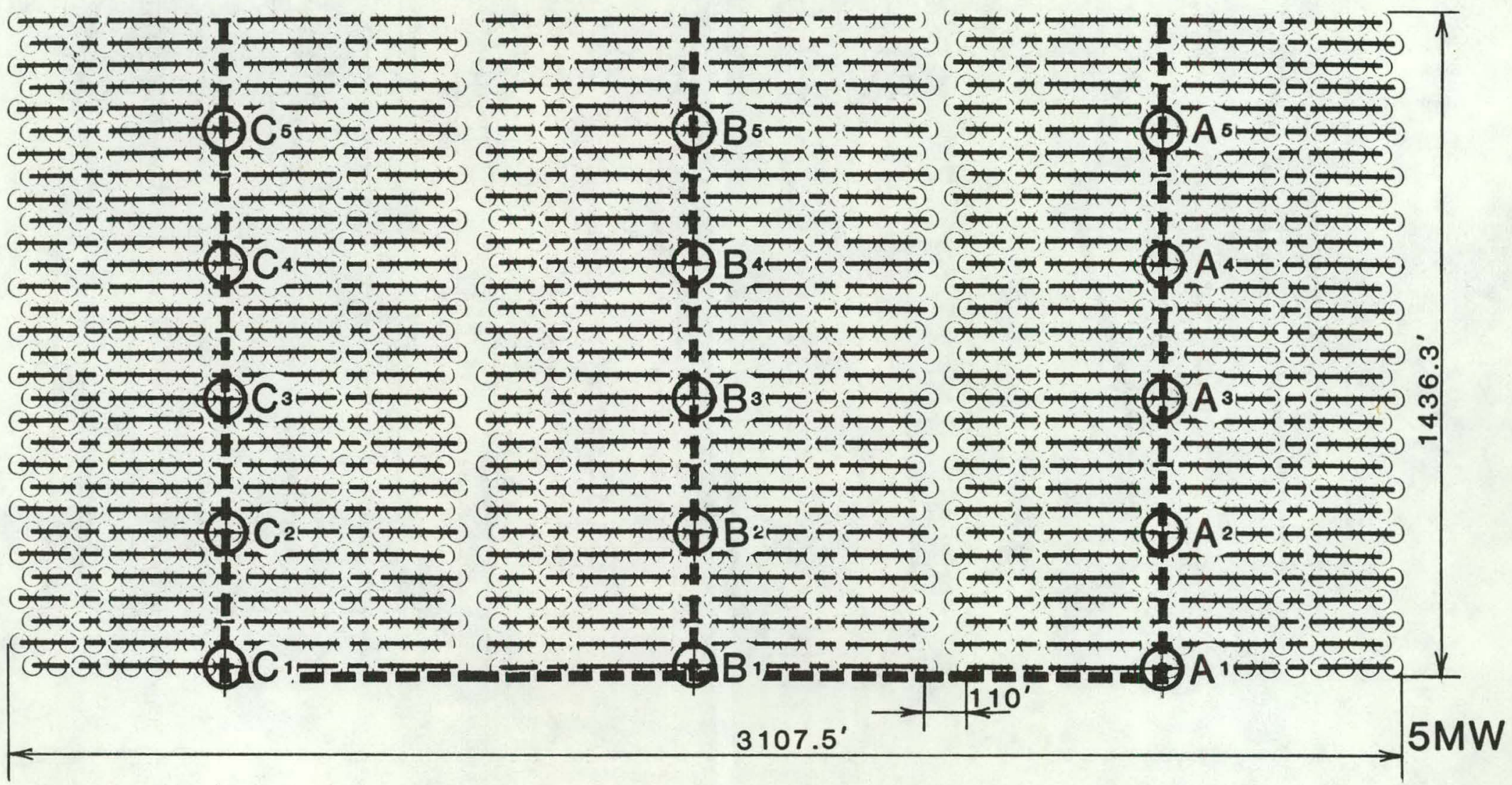



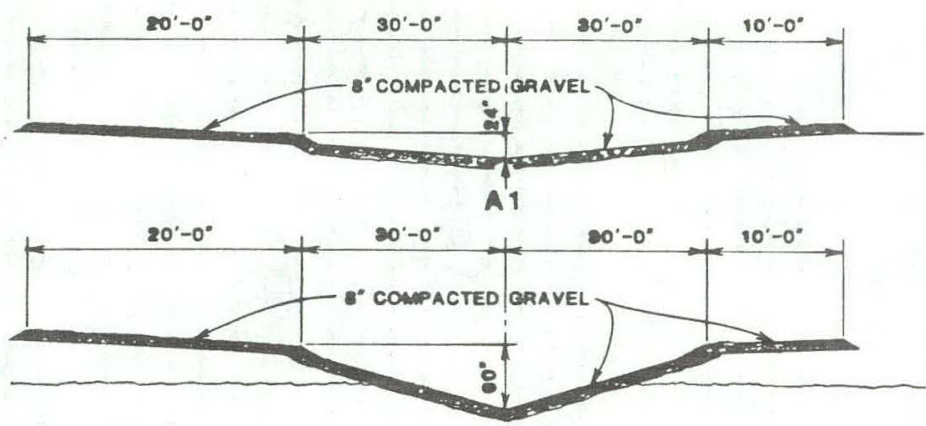

A2
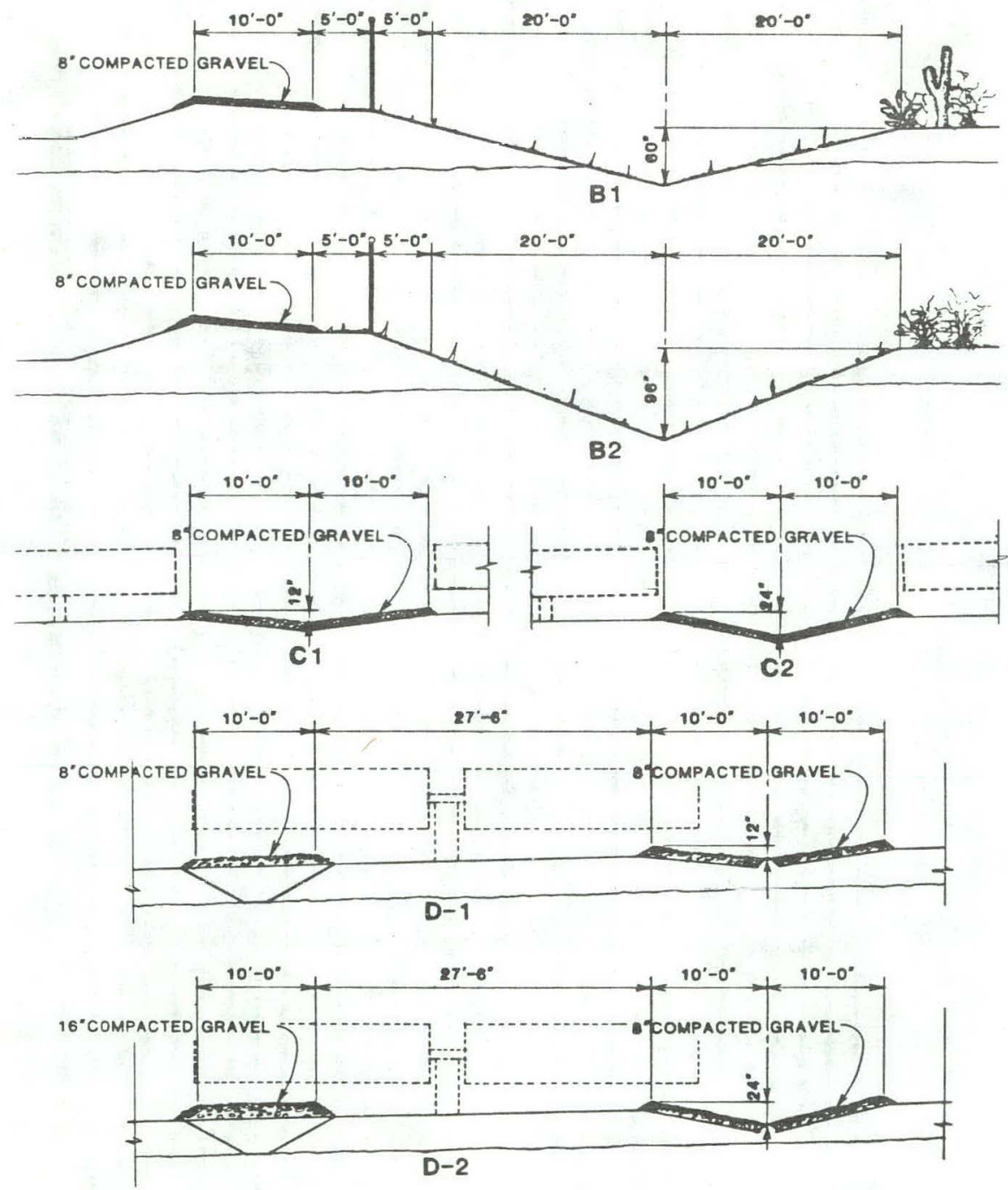

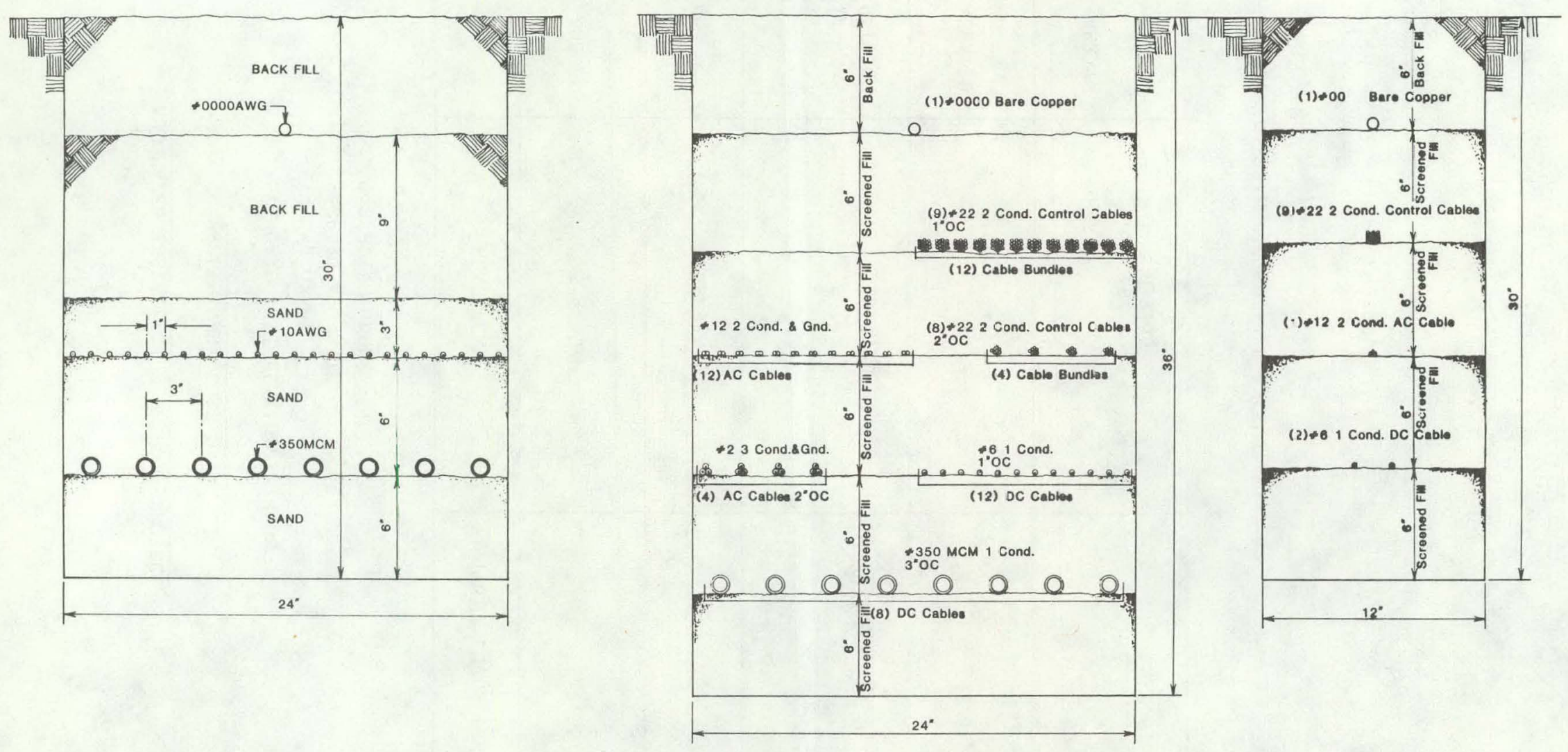


\section{AUTOMATED INSTALLATION METHODS PROJECT}

PRELIMINARY COST DATA

- STANDARD INSTALLATION METHODS

- $10 \mathrm{MW}_{\mathrm{P}}$ ARRAY

- SAguaro APU Site

- $0 \&$ P INCLUDED

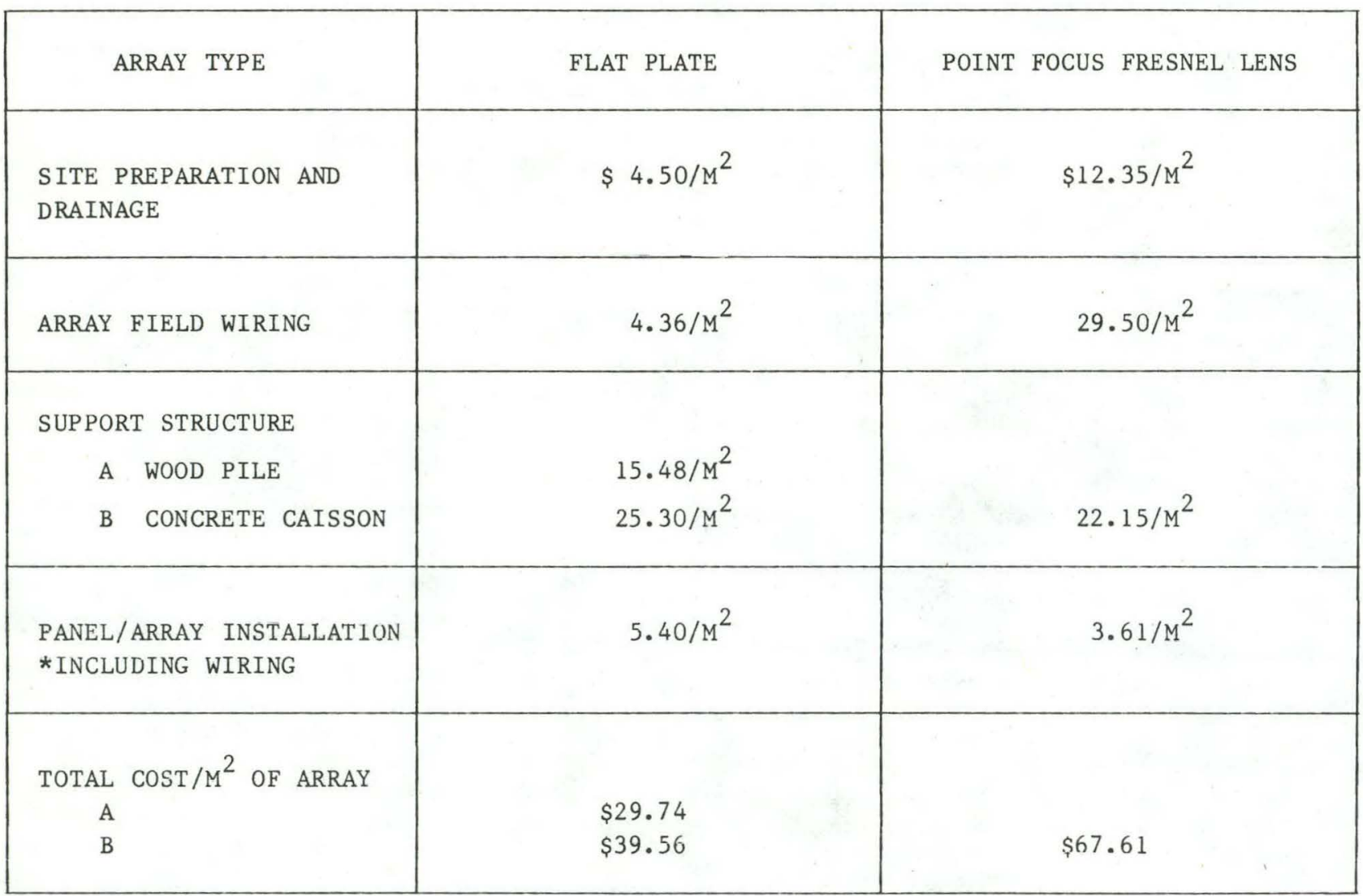

NOTE: COST DATA IS PRELIMINARY AND IS NOT ALL INCLUSIVE. 
AUTOMATED/MECHANIZED INSTALLATION SCENARIO

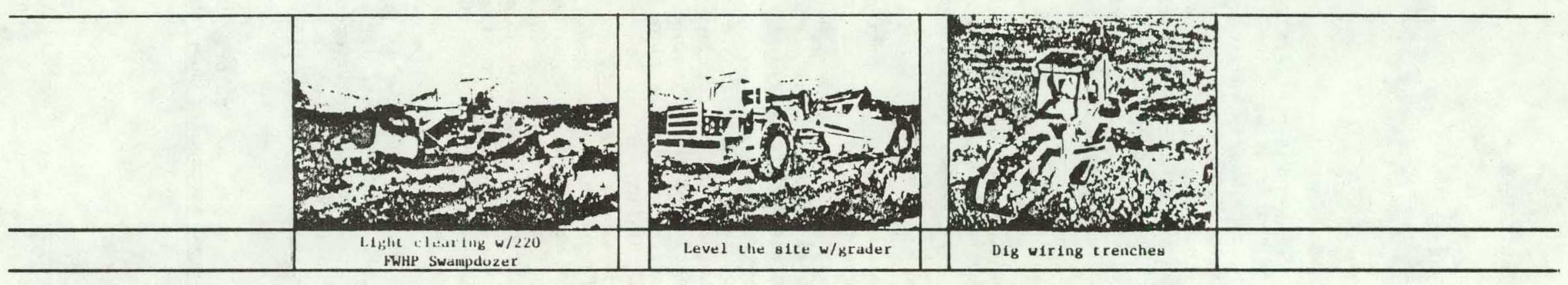

๒

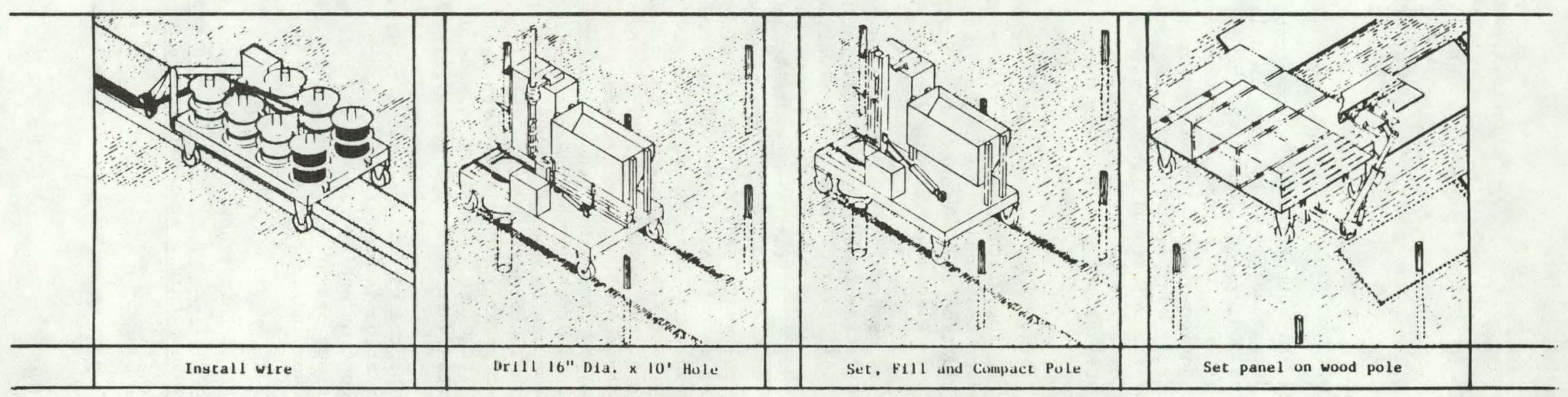




\title{
FLAT-PLATE ARRAY CHARACTERIZATION
}

Charles C. Gonzalez

Jet Propulsion Laboratory

Pasadena CA 91109

\begin{abstract}
The electrical output (power, current and voltage) of flat-plate arrays changes constantly, due primarily to changes in cell temperture and irradiance level. As a result, the power conditioner must be able to accommodate widely varying input levels and must attempt to operate at or near the array maximum power point at all times. Efficient design of photovoltaic power conditioners therefore requires detailed knowledge of array operating characteristics and extreme output 1 imits. In response to this need, the Jet Propulsion Laboratory (JPL) is making a study, nearing completion, designed to define the array operating characteristics for a variety of sites in the United States and to provide data on the performance advantages of various powerconditioner operating modes.
\end{abstract}

A number of interface parameters are considered, including optimum operating voltage, voltage tracking width necessary to capture various fractions of the available energy, maximum power and current limits, and maximum open circuit voltage. The effect of array degradation and I-V curve fill factor on the array-power conditioner interface parameters is also being studied.

The analysis methodology is based on hour-by-hour simulations using ambient temperature and irradiance data from SOLMET TMY weather data tapes for each of the 26 sites examined. All results have been normalized to the array maximum power parameters at Standard Operating Conditions: $100 \mathrm{~mW} / \mathrm{cm}^{2}$, at Nominal Operating Cell Temperature (NOCT). NOCT is defined at $80 \mathrm{~mW} / \mathrm{cm}^{2}, 20^{\circ} \mathrm{C}$ ambient air temperature.

Example results are provided for a limited number of sites. The array energy output is given as a function of the voltage tracking width about the determined optimum operating voltage. Energy output is given as a fraction of that obtained with unlimited voltage tracking width. The annual array energy output was also determined as a function of the maximum operating array power and current for two power-conditioner opeating strategies. In one strategy the power conditioner ceases to accept power until array environmental conditions change, lowering the operating power and current. In the second strategy the power conditioner has the ability to change the array operating parameters by use of a shunt or displacement of the operating point on the array $I-V$ curve. Therefore, the only loss in energy results from operation at other than the maximum power point. Also provided is an estimate of the maximum array opencircuit voltage. A comparison is made of the results obtained, as described above, for two sites when array I-V curve fill factor is varied.

A summary of the variations in the results obtained for the 26 sites is presented, as is the variation in results with change in fill factor. The largest differences exist in the amount of energy gained with voltage tracking, with lesser differences in the actual optimum operating voltage. Some significant differences also arise in the maximum power and current limits, and maximum open-circuit voltage obtained from site to site.

The results of this study are to be incorporated in a Sandia Laboratories document, Baseline Specification of a Utility-Interactive Power-Conditioning Subsystem for Residential Photovoltaic System Applications. 


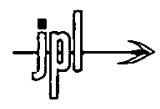

\title{
FLAT-PLATE ARRAY CHARACTERIZATION
}

\author{
By \\ C. Gonzalez

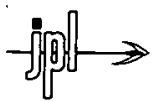 \\ FEBRUARY 11, 1982 \\ Jet Propulsion Laboratory \\ Pasadena, California
}

\section{OBJECTIVE}

To Characterize Flat-Plate Arrays by Determining Significant Array Operating Parameters

- Determine:

- Optimum Operating Voltage

- Operating Voltage Range Required to Obtain a Given Amount of Energy Annually

- Maximum Power and Current Limits Required to Obtain a Given Amuunt of Energy Annually

- Maximum Open-Clrcuit Voltage

- Changes in Values of Optimum and Maximum Operating Parameters With Array Degradation 


\section{APPROACH}

- Calculate Effect of Arraý-Power Conditioner

Operational Interface Parameters on System

Annual Energy Production:

- Annual Energy Based on Hour-by-Hour

Simulation Using Array Temperature and

Irradiance From SOLMET TMY Tapes

- 26 Site Locations in U.S.

- All Parameters Normalized to Array Maximum-Power Parameters at Standard

Operating Conditions (SOC $=$ NOCT, $100 \mathrm{~mW} / \mathrm{cm} 2$ )

\section{CASES ANALYZED}

- Fraction of Available Energy:

- For Fixed Voltage Power Conditioner, With and Without Seasonal Adjustment

- Vs Power Conditioner Tracking Range

- Vs Maximum Operational Power and Current Limits for Two Strategies

- Rejection of All Array Power When Limits Are Exceeded (Total Power Rejection)

Partial Rejection of Power When Limits Are Exceeded (Partial Power Rejection)

- Maximum Expected Open-Circuit Voltage 


\section{FRACTION OF AVAILABLE ENERGY FOR FIXED-VOLTAGE POWER CONDITIONER \\ ALBUQUERQUE NM}

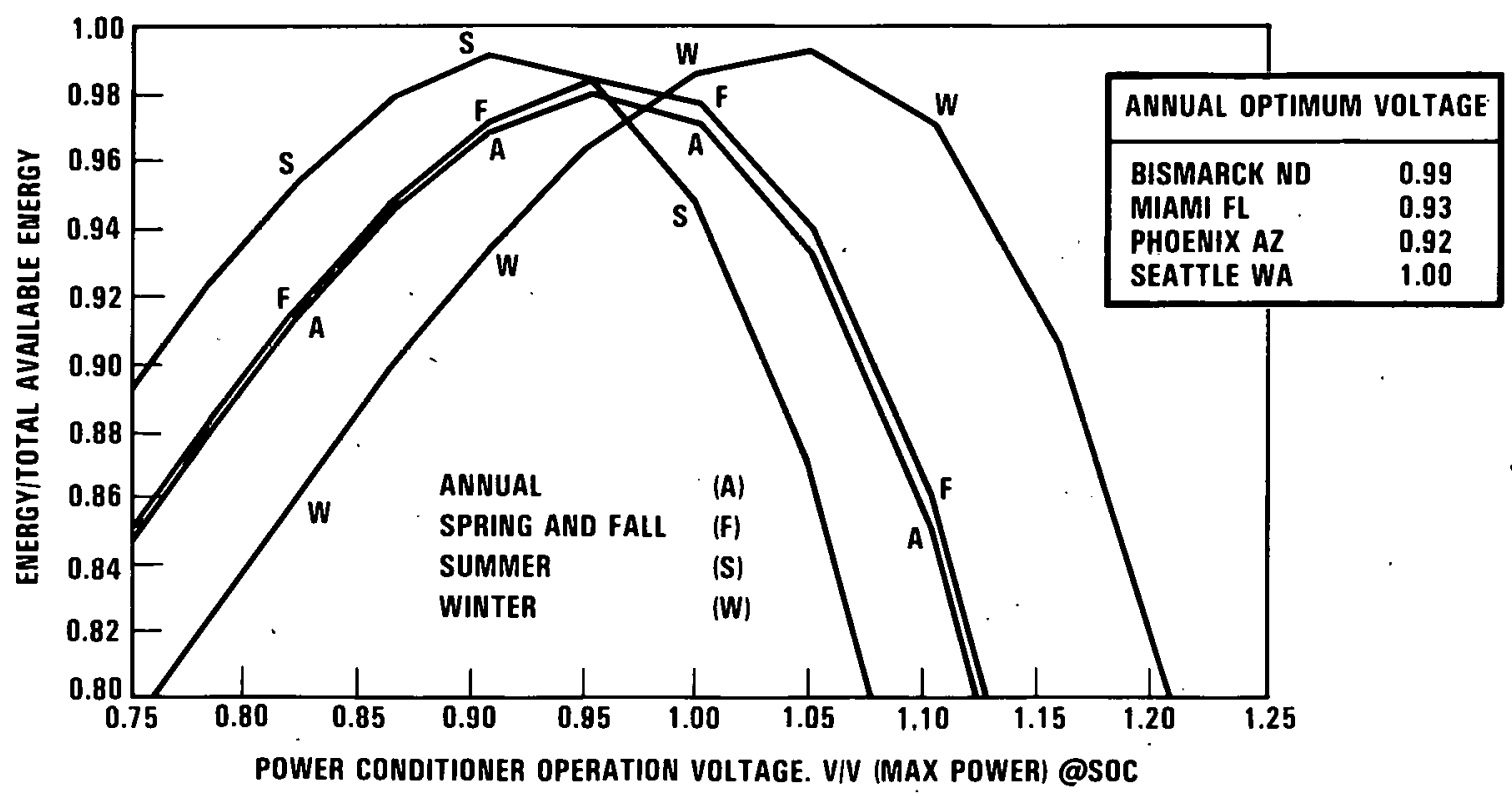

ANNUAL ENERGY LOSSES vS POWER CONDITIONER VOLTAGE TRACKING RANGE

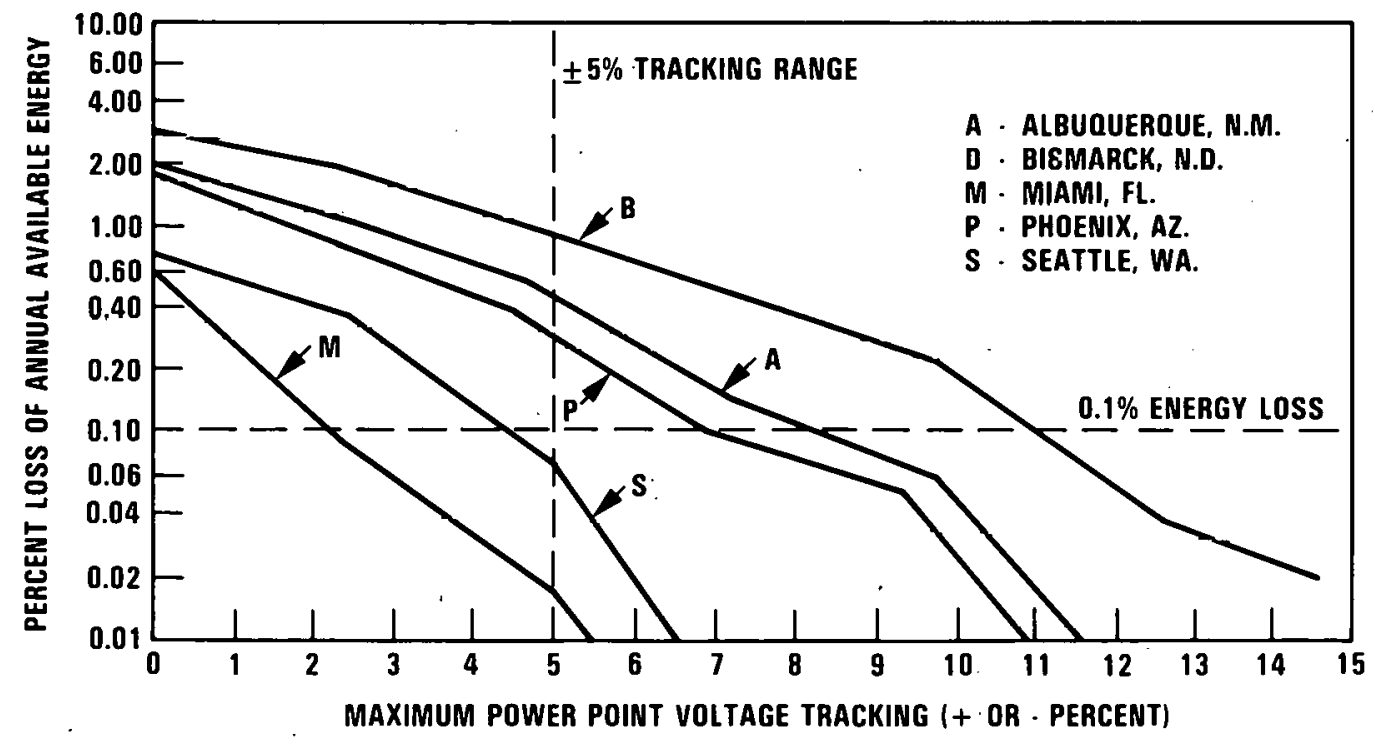




\section{POWER CONDITIONER MAXIMUM OPERATING LIMITS}

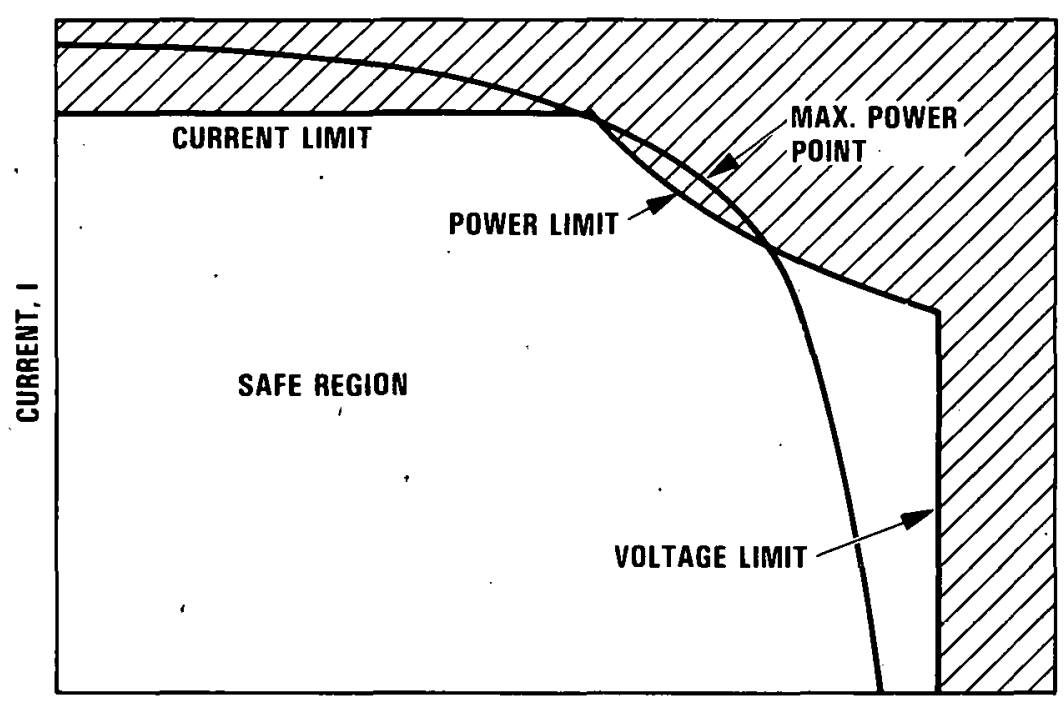

VOLTAGE, $V$

\section{ARRAY POWER OUTPUT vs POWER AND CURRENT LIMITS}

- Algorithms Simulate Two Strategies When Limits Are Exceeded

- Strategy 1: Total Rejection of All Array Power

- Strategy 2: Partial Rejection of Array Power

- 2A: Move Off Maximum Power Point

- 2B: Use of Shunt to Dissipate Excess Power
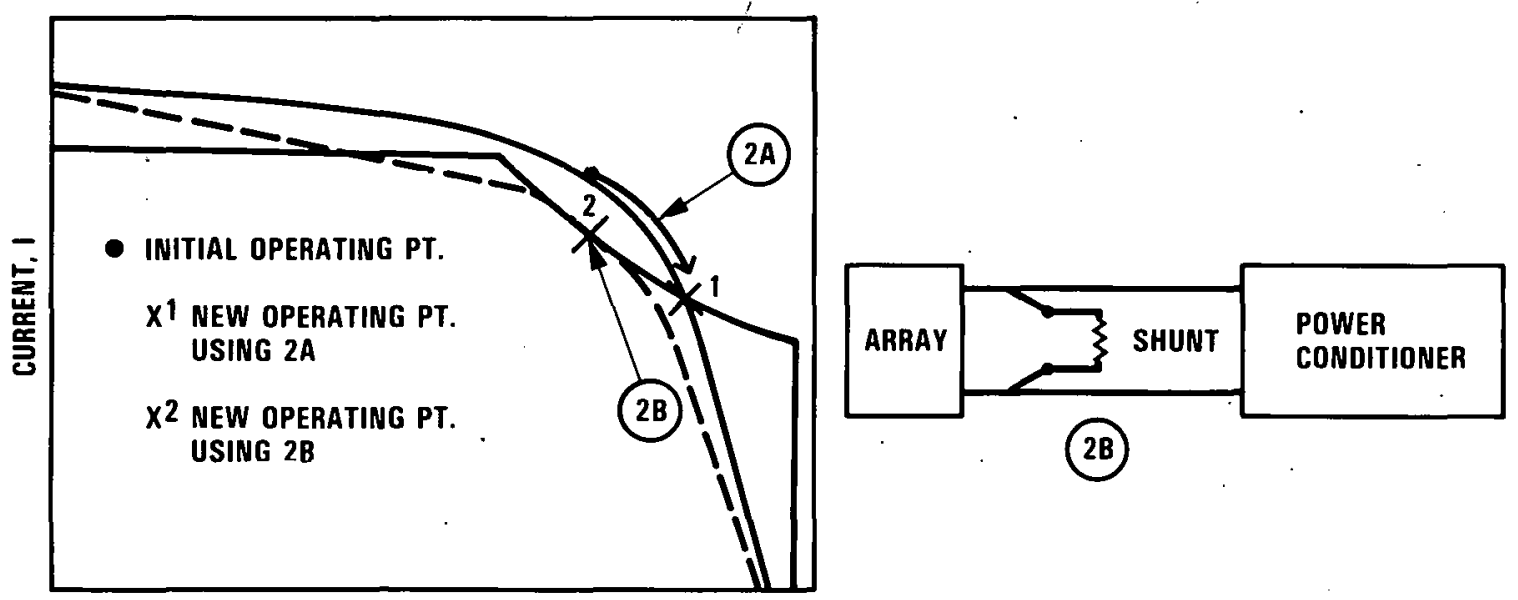

(2B)

VOLTAGE, $V$ 


\section{FRACTION OF ANNUAL ARRAY ENERGY \\ vS \\ POWER CONDITIONER CURRENT LIMIT \\ ALBUQUERQUE NM}

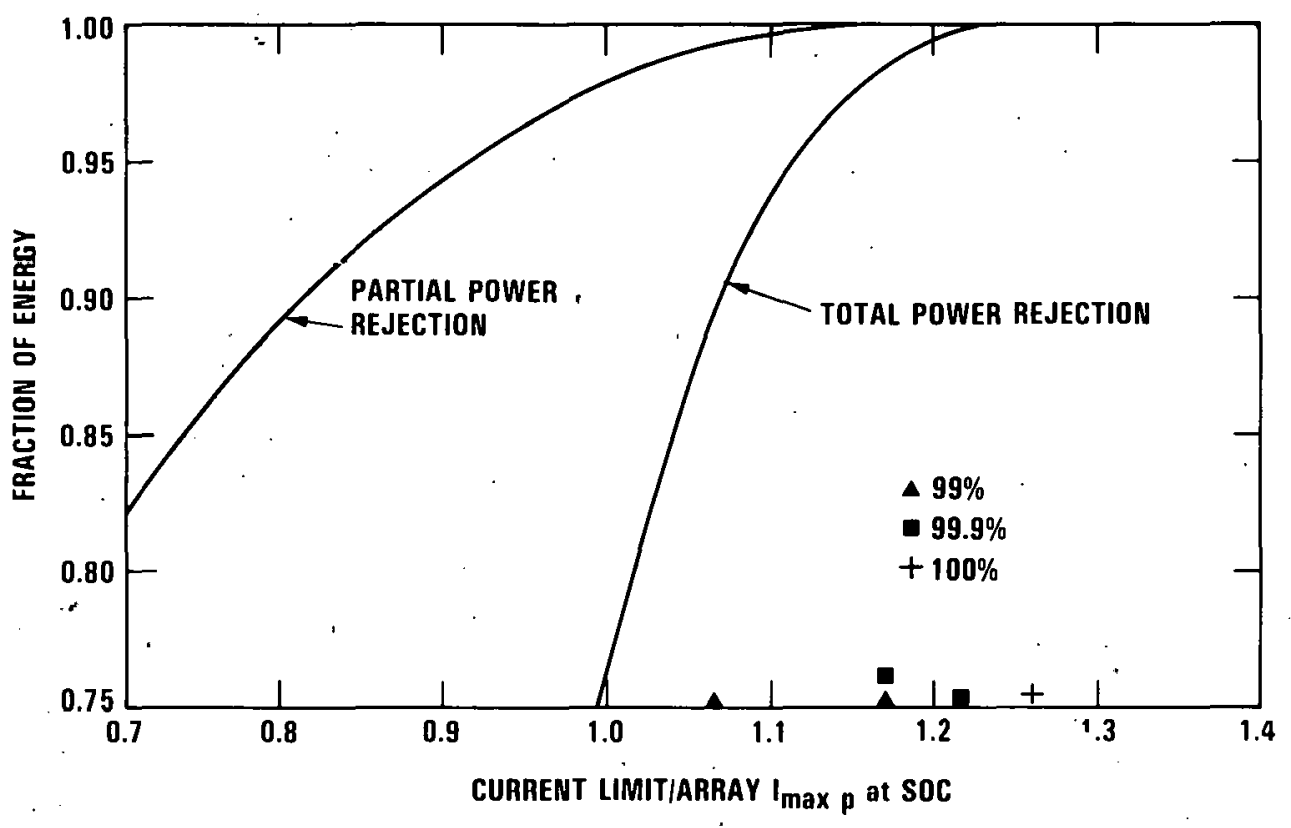

\section{ARRAY CURRENT LIMITS REQUIRED TO OBTAIN A GIVEN PERCENTAGE OF AVAILABLE ENERGY}

\begin{tabular}{|l|c|c|c|c|c|}
\cline { 2 - 5 } \multicolumn{1}{c|}{} & \multicolumn{2}{c|}{$\begin{array}{c}\text { TOTAL POWER } \\
\text { REJECTION }\end{array}$} & \multicolumn{2}{c|}{$\begin{array}{c}\text { PARTIAL POWER } \\
\text { REJECTION }\end{array}$} & \multirow{2}{*}{ 100\%" } \\
\cline { 1 - 5 } \multicolumn{1}{c|}{ SITE } & $99 \%$ & $99.9 \%$ & $99 \%$ & $99.9 \%$ & \\
\hline ALBUQUERQUE NM & 1.18 & 1.21 & 1.06 & 1.18 & 1.38 \\
\hline BISMARCK ND & 1.09 & 1.10 & 0.95 & 1.08 & 1.24 \\
\hline MIAMI FL & 0.96 & 1.08 & 0.85 & 1.00 & 1.20 \\
\hline PHOENIX AZ & 1.13 & 1.17 & 0.99 & 1.13 & 1.24 \\
\hline SEATTLE WA & 0.92 & 1.00 & 0.87 & 0.93 & 1.18 \\
\hline
\end{tabular}

"VALUE OBTAINED FROM ANALYSIS INCREASED BY 10\% TO ACCOUNT FOR EXTREME ENVIRONMENTAL CONOITINNS 


\section{MAXIMUM OPEN CIRCUIT VOLTAGE}

Lower Limit

- Simultaneous Ambient Temperature and Irradiance

That Gives Largest $V_{\text {oc }}$

Upper Limit

- Lowest Ambient Temperature on TMY Tape Combined With $100 \mathrm{~mW} / \mathrm{cm}^{2}$

Site

Albuquerque NM

Bismarck ND

Miami FL

Phoenix AZ

Seattle WA $\underline{\text { Lower Limit Upper Limit }}$

1.67

1.83

1.57

1.59

1.61
1.80

1.91

1.71

1.74

1.71

POWER vS VOLTAGE AS A FUNCTION OF

FILL FACTOR FOR TWO IRRADIANCE LEVELS

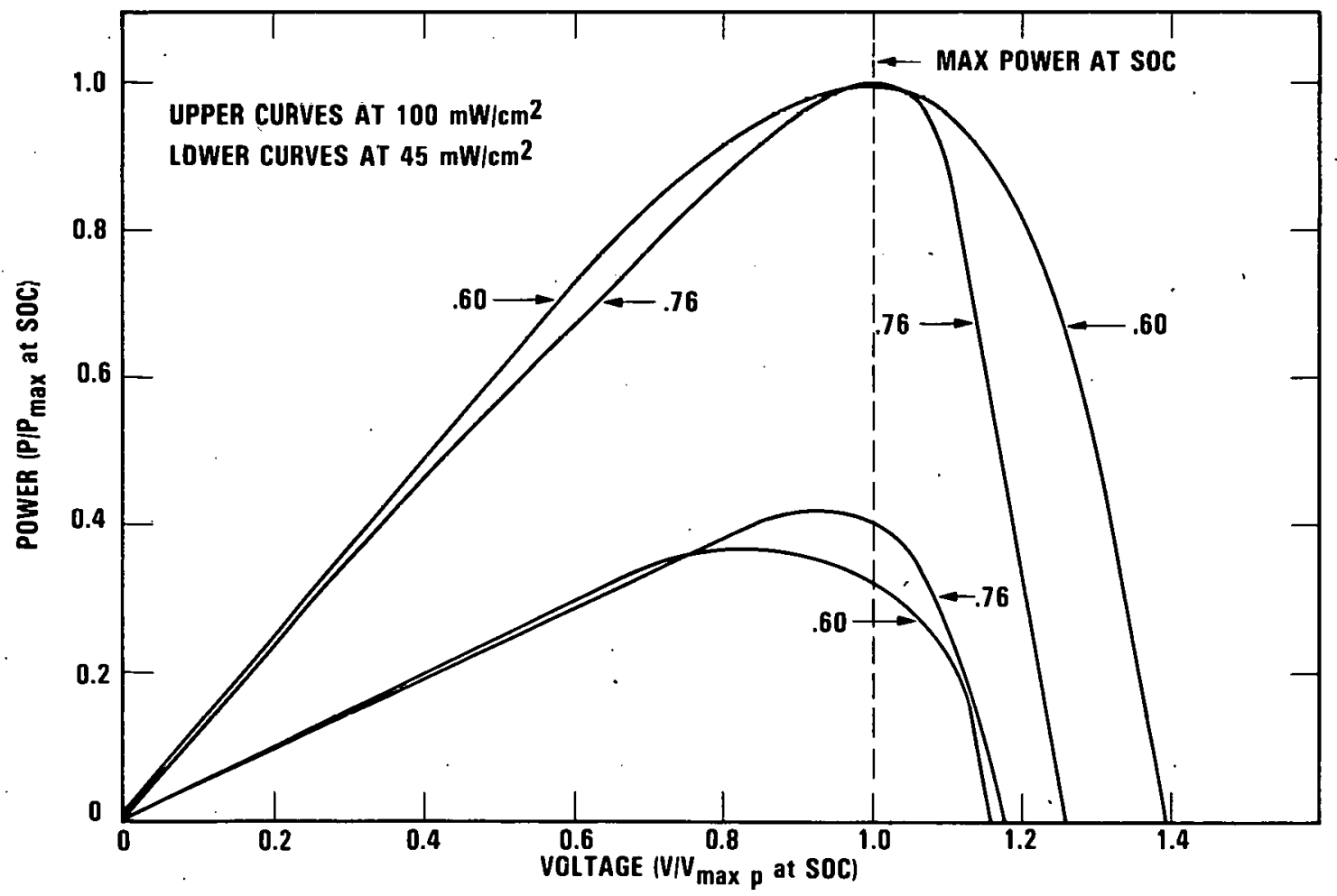




\section{COMPARISON OF RESULTS OBTAINED WITH DIFFERENT I.V CURVE FILL FACTORS}

\begin{tabular}{|c|c|c|c|c|c|}
\hline \multirow[t]{2}{*}{ FILL FACTOR } & \multirow{2}{*}{$\begin{array}{l}\text { ENERGY LOSS } \\
\text { WITHOUT VOLTAGE } \\
\text { TRACKING } \\
\text { (PERCENTAGE) }\end{array}$} & \multirow{2}{*}{$\begin{array}{l}\text { VOLTAGE TRACKING } \\
\text { WIDTH REQUIRED TO } \\
\text { REDUCE LOSS TO } 0.1 \% \\
\text { ( } \pm \text { PERCENTAGE) }\end{array}$} & \multirow[t]{2}{*}{$\begin{array}{l}\text { OPTIMUM } \\
\text { OPERATING } \\
\text { VOLTAGE }\end{array}$} & \multicolumn{2}{|c|}{$\begin{array}{l}\text { CURRENT LIMIT REQUIRED } \\
\text { TO OBTAIN GIVEN PERCENTAGE } \\
\text { OF ENERGY }\end{array}$} \\
\hline & & & & $99 \%$ & $99.9 \%$ \\
\hline \multicolumn{6}{|c|}{ ALBUQUERQUE NM } \\
\hline .60 & 1.55 & 7.8 & 0.94 & 1.03 & 1.13 \\
\hline .64 & 1.60 & 7.8 & 0.95 & 1.04 & 1.15 \\
\hline .68 & 1.65 & 7.0 & 0.95 & 1.05 & 1.15 \\
\hline .72 & 1.90 & 6.2 & 0.96 & 1.06 & 1.18 \\
\hline .76 & 2.50 & 6.3 & 0.96 & 1.07 & 1.18 \\
\hline \multicolumn{6}{|c|}{ BOSTON MA } \\
\hline .60 & 2.50 & 8.0 & 0.92 & 0.89 & 1.05 \\
\hline .64 & 2.40 & 8.5 & 0.94 & 0.89 & 1.05 \\
\hline .68 & 2.00 & 7.8 & 0.96 & 0.89 & 1.05 \\
\hline .72 & 1.60 & 5.5 & 0.99 & 0.89 & 1.05 \\
\hline .76 & 1.70 & 4.6 & 1.00 & 0.90 & 1.05 \\
\hline
\end{tabular}

\section{CONCLUSIONS}

- Site-to-Site Variations

- Optimum Voltage: 0.92 - 1.01

- Advantages of Voltage Tracking: $0.5 \%$ to $3 \%$ Gain in Annual Energy

- Maximum Power and Current Limite

- Variations in Upper Limits to Obtain 99\% of Available Energy With the Two Strategies Are Uniform (15\% Higher for Total Rejection of Power)

- Maximum Open-Circuit Voltage: Upper Limits Range From 1.7 to 1.9

- Fill Factor Variations

- Significant Differences in Energy Gain With Full-Range Voltage Tracking

- Differences in Optimum Operating Voltage Negligible at Some Sites, Significant at Others

- Moderate Differences in Required Current Limits 
DYNAMIC SIMULATION OF DISPERSED

GRID CONNECTED PHOTOVOLTAIC

POWER SYSTEMS

\author{
P. C. Krause \\ o. Wasynzuk \\ Purdue University \\ W. Lafayette, IN 47907
}

The primary objective of this work is to determine and evaluate the dynamic electrical behavior of respresentative distribution grids containing perhaps significant penetrations of dispersed PV generation. This includes the determination of (1), the individual PV system behavior at the secondary distribution level, (2) the overall distribution system response with dispersed PV generation and (3) the collective effects of dispersed PV generation at the transmission Level.

The work is divided into 4 tasks: (1) PV system model development, (2) Distribution system simulation, (3) Transmission system simulation, (4) Interpretation and analysis of results. Work on Task (1) is nearing completion (the anticipated completion date is March 31, 1982). This presentation focuses on the inverter simulation models developed and key results cbtained heretofore. A report on Task 1 results will be written upon completion of the technical effort. 
OVERALL WORKPLAN

$J \quad J \quad A^{1981} S \quad O \quad N \quad D \quad J \quad F \quad M$.

TASK 1. PV SYSTEM MODEL DEVELOPMENT

1982

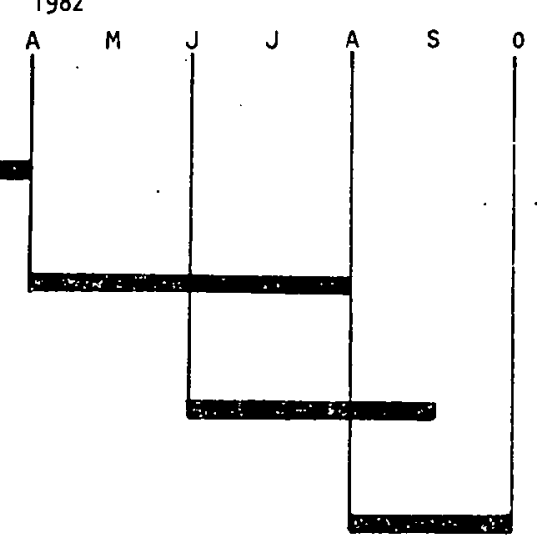

TASK 4. INTERPRETATION OF SIHULATIONS

TASK 2. DISTRIBUTION SYSTEM SIMULATIGH

TASK 3. TRANSHISSION SYSTEM SIMULATION

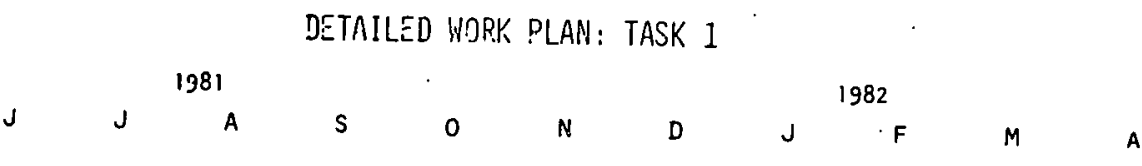

SUBTASK 1.1 DEVELOPMENT OF INVERTER MODELS

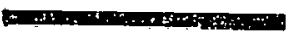

SUBTASK J.2 CONTROL SYSTEM MODEL DEVELOPMENT

Ex+1.

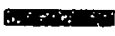

SUBTASK 1.3 REVIEW AND ASSESSMENT OF ALTERNATE CONTROLS

$2+2 \times$.

SIJBTASK $i .4$ CONTROL SYSTEM DEVELOMMENT

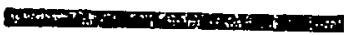

SURTASK 1,5 PV ARRAY MONFL ING

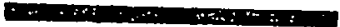

and

SUBTASK 1.5 MODEL INTERCONNECTION AND SYSTENI STUDIES 
HYBRID FACILITIES

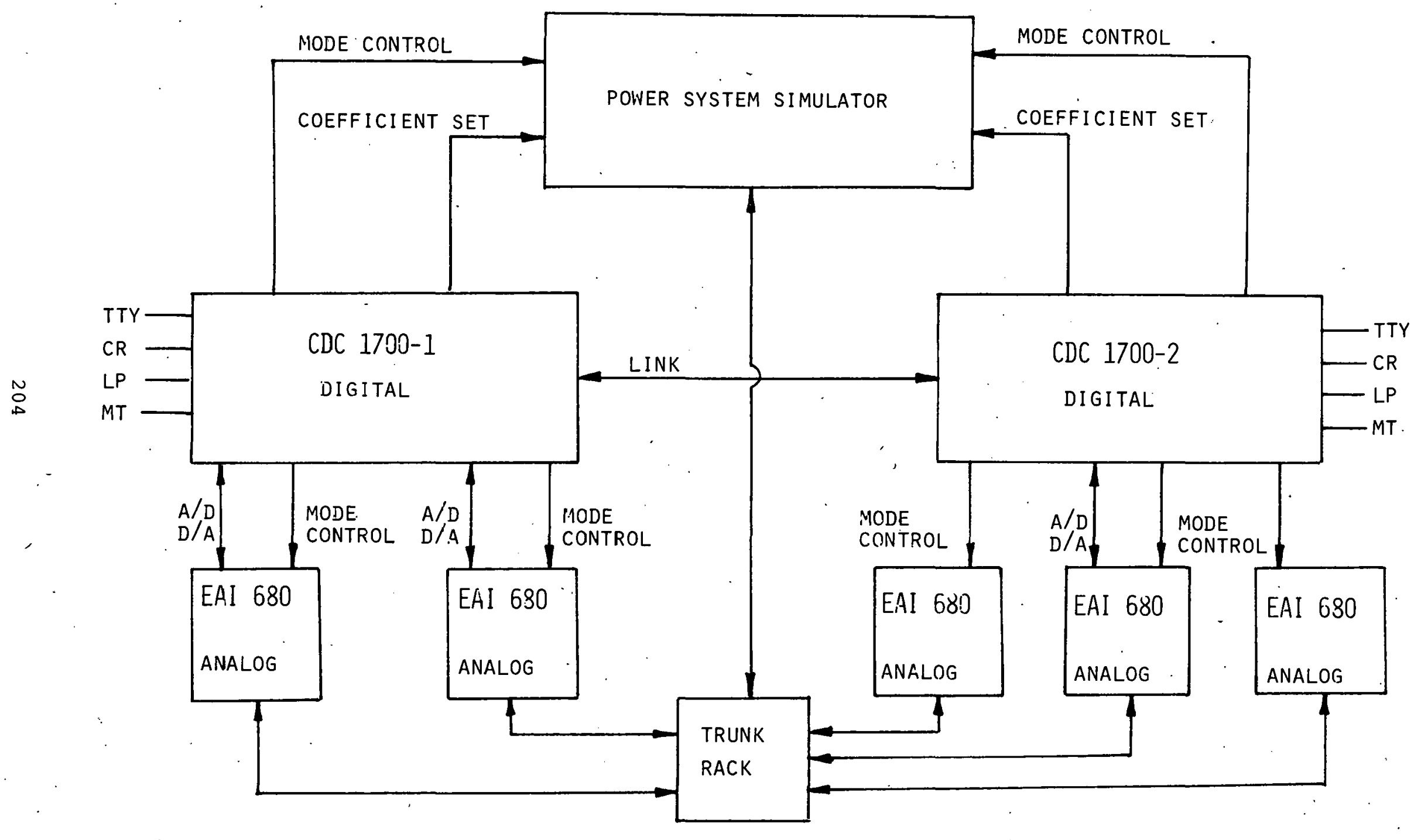


INVERTER TOPOLOGIES SIMULATED
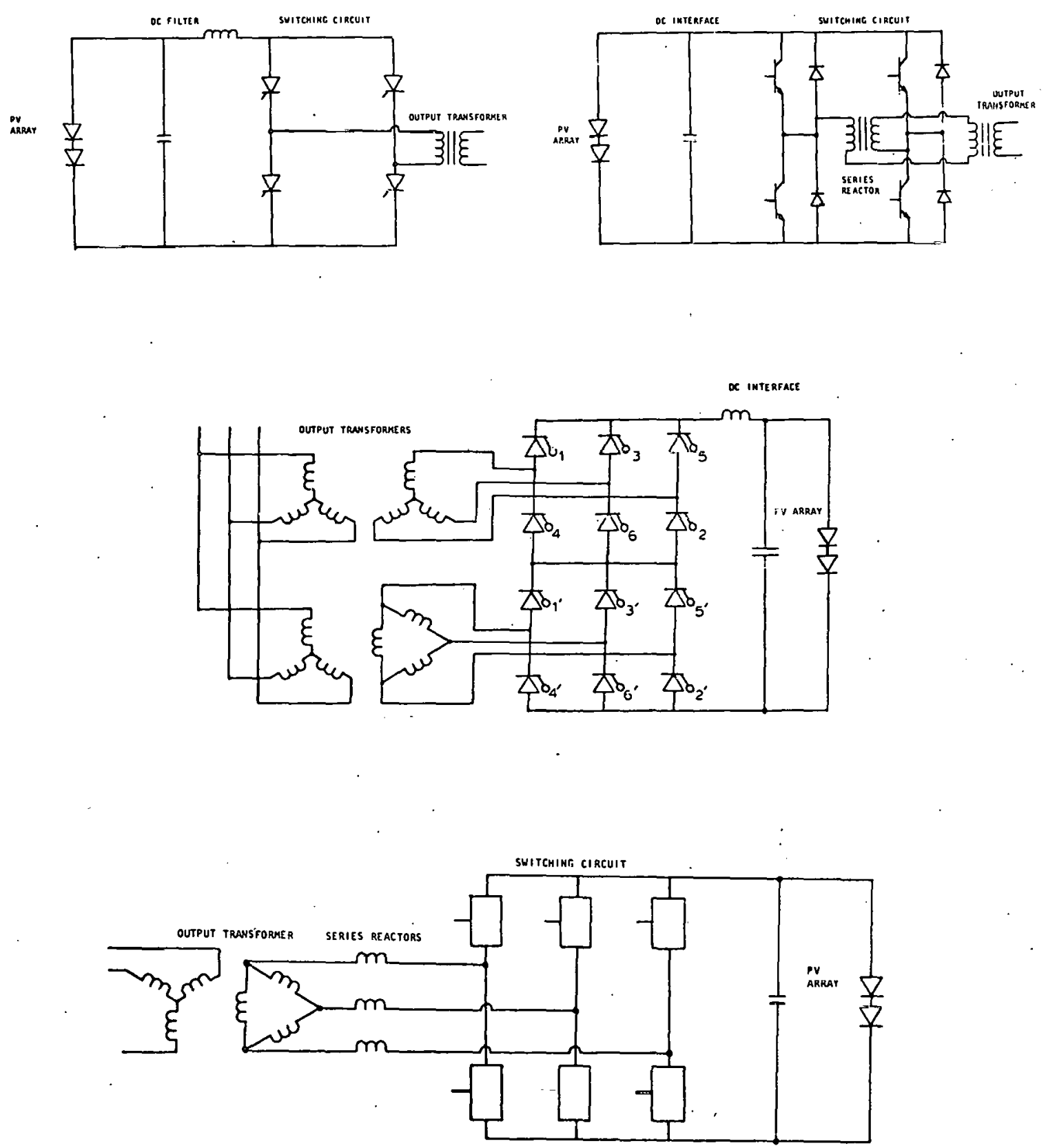
SIMULATION BLOCK DIAGRAM

LIME COMMUTATED INVERTER

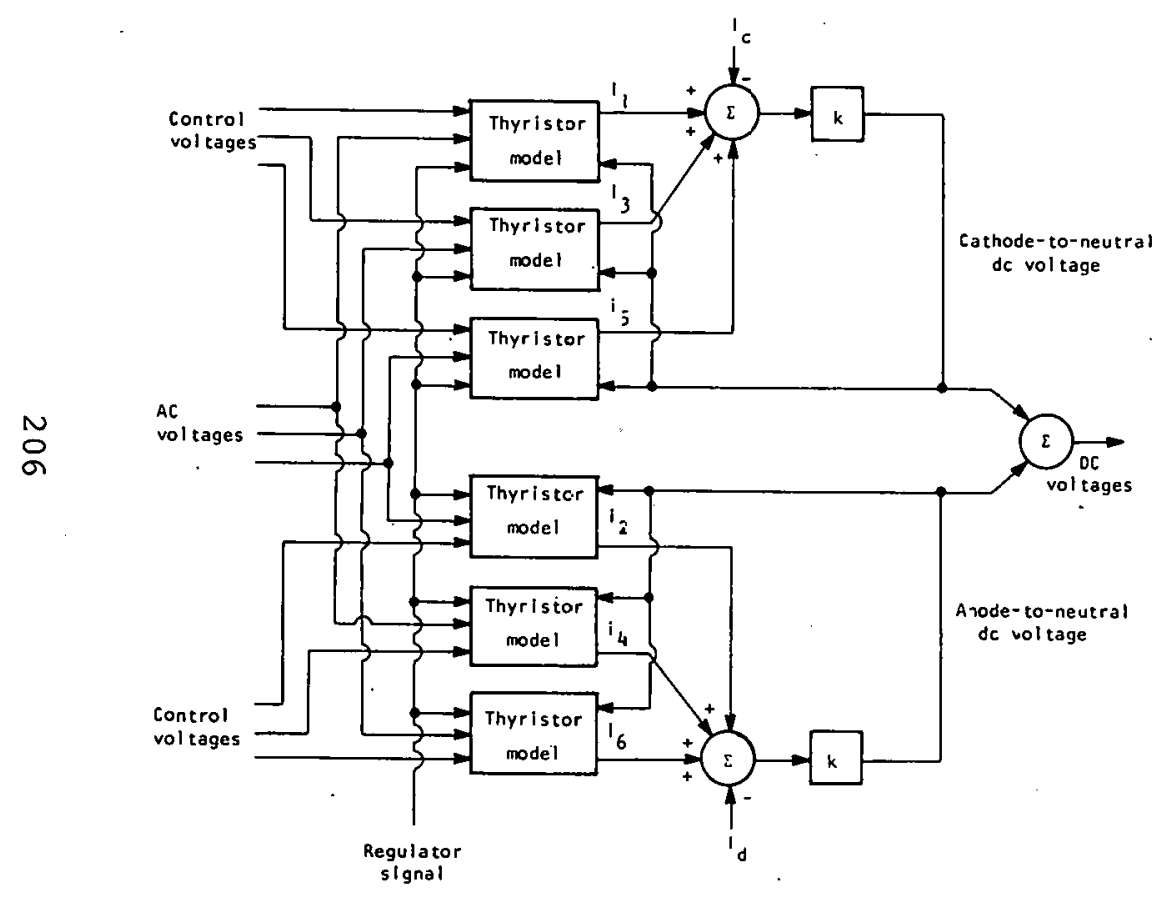

SIMULATION BLOCK DIAGRAM

SELF COMMUTATED INVERTER

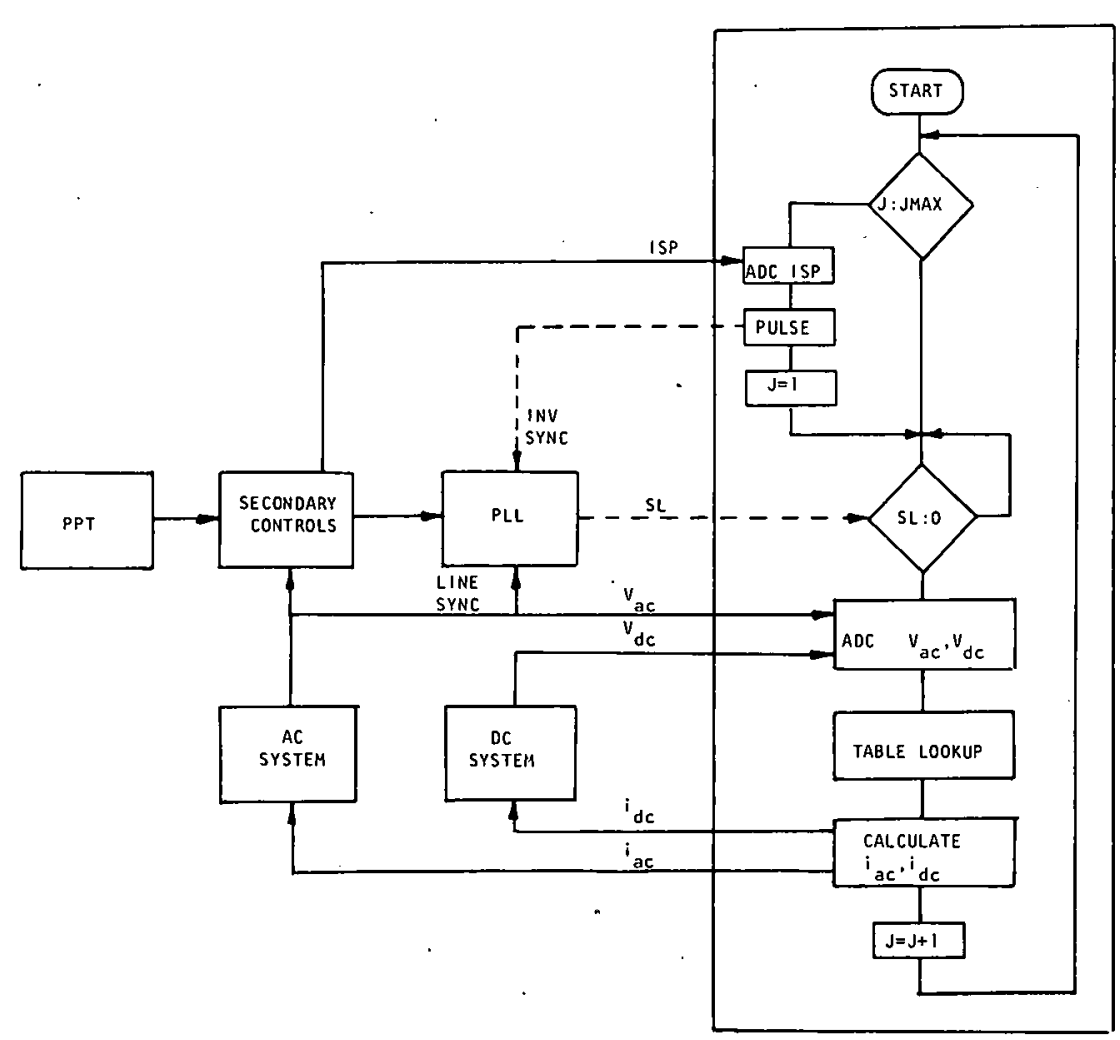


CONTROL SYSTEM BLOCK DIAGRAM: SELF COMMUTATED INVERTER

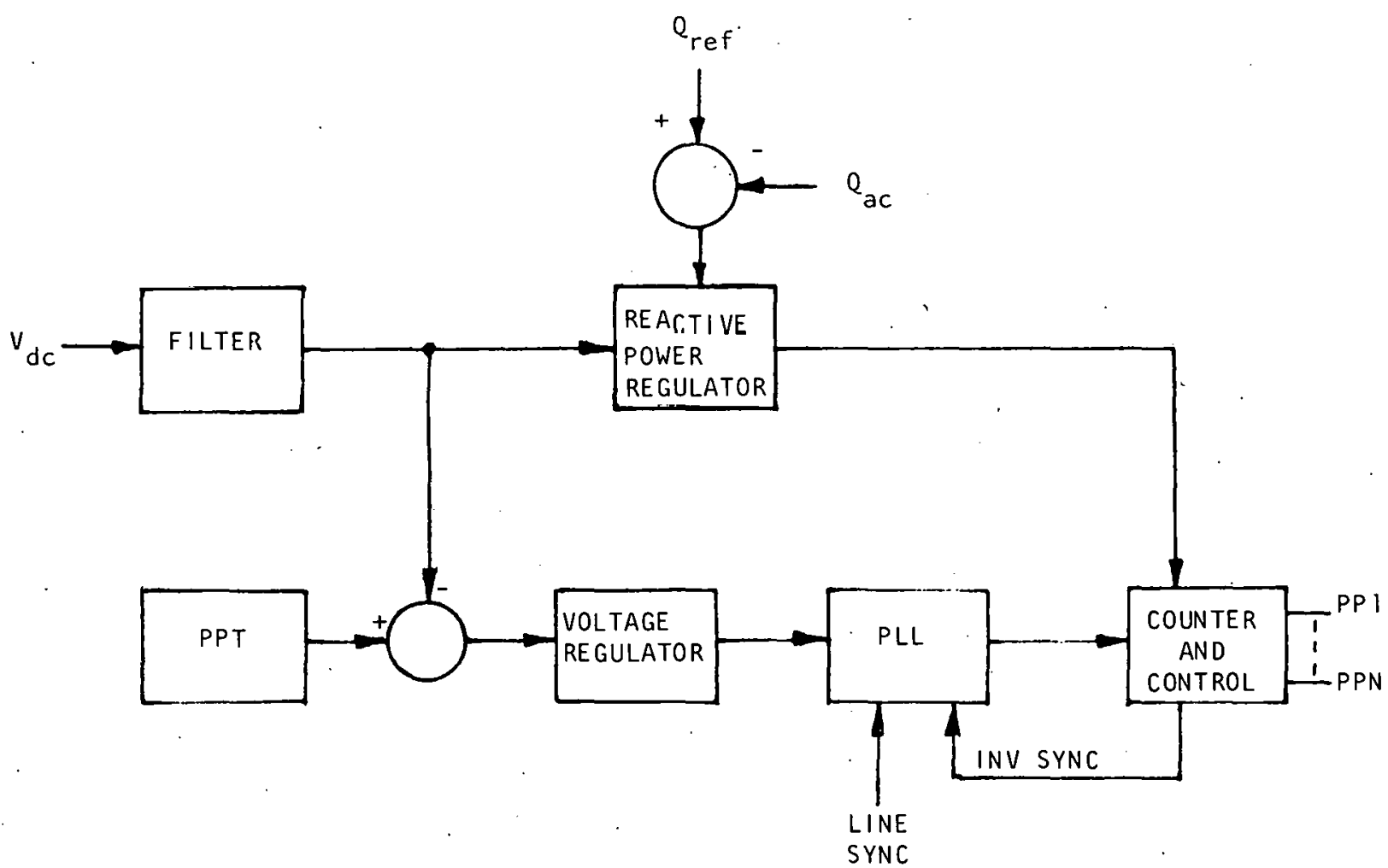

CONTROL SYSTEM BLOCK DIAGRAM: LINE COMMUTATED IMVERTER

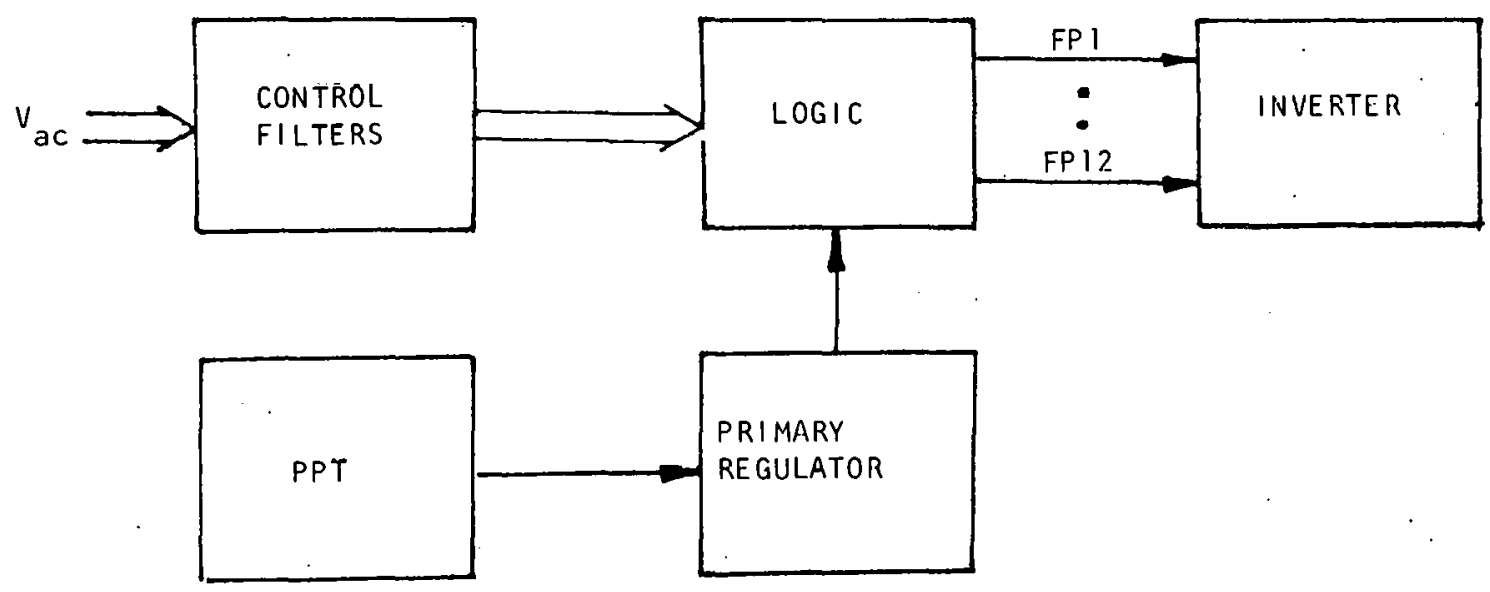


PERTURB AND OBSERVE PEAK POWER TRACKER
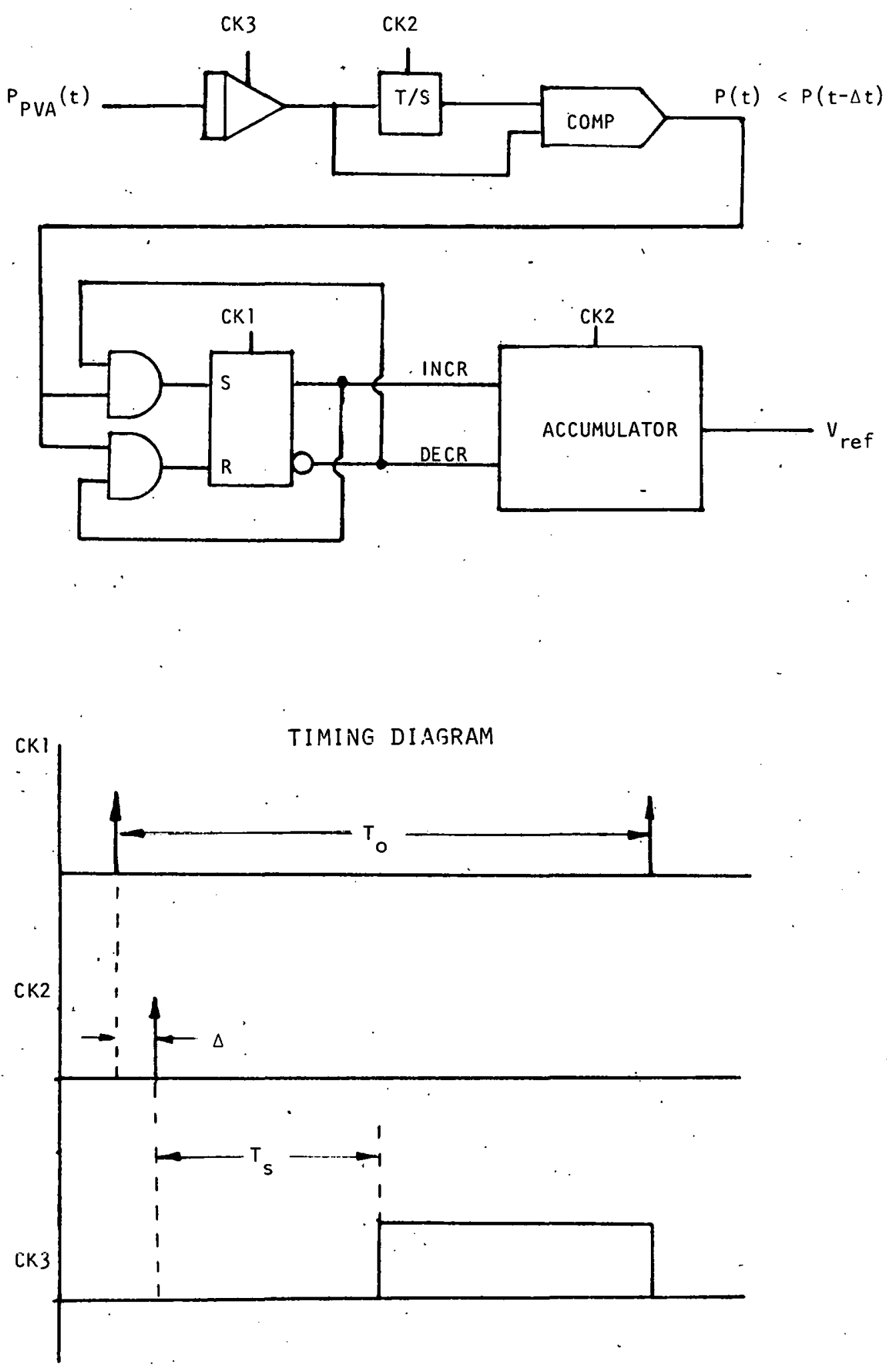
SIMULATION STUDY OF CLOUD COVER TRANSIENT
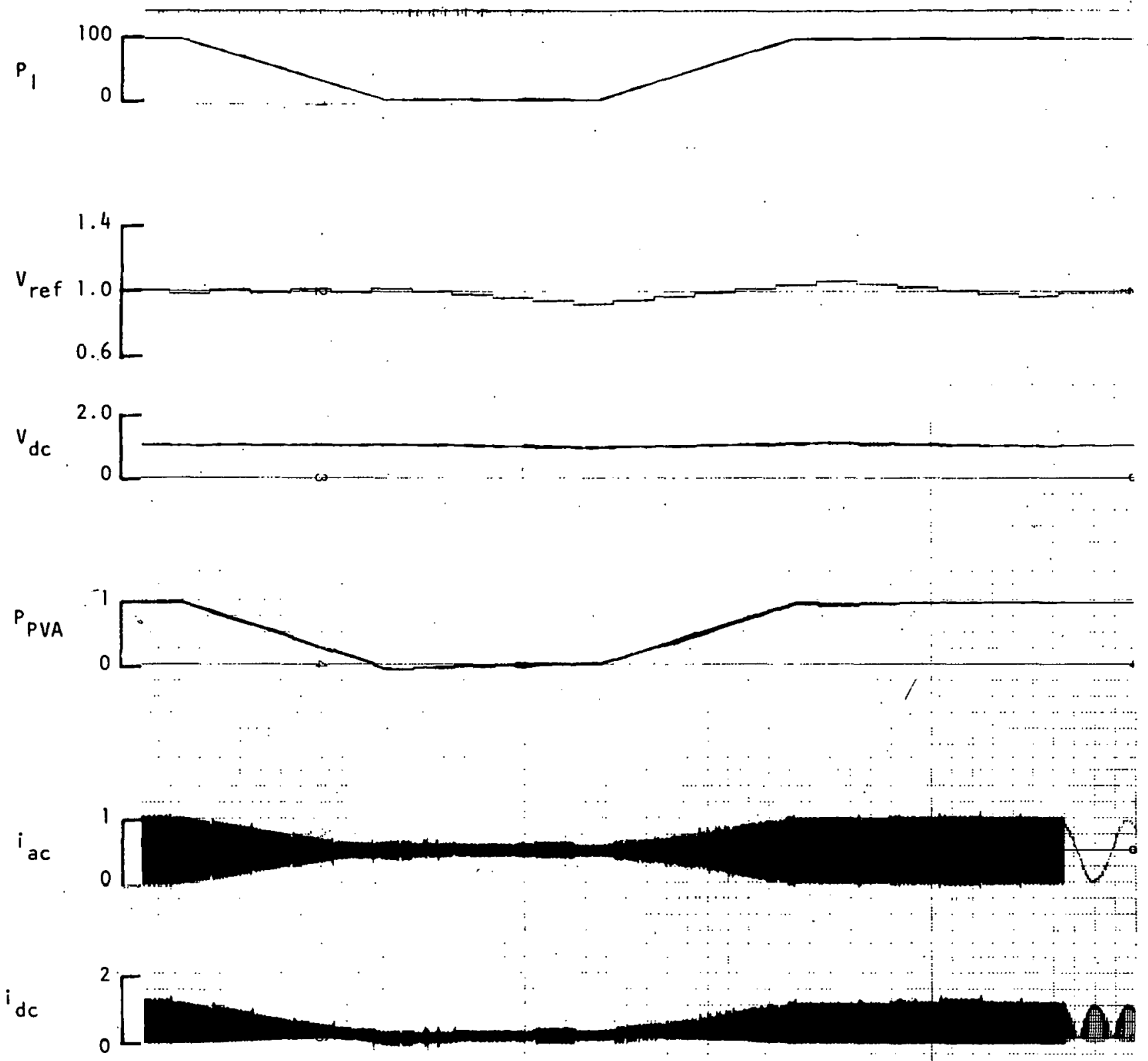

CKI

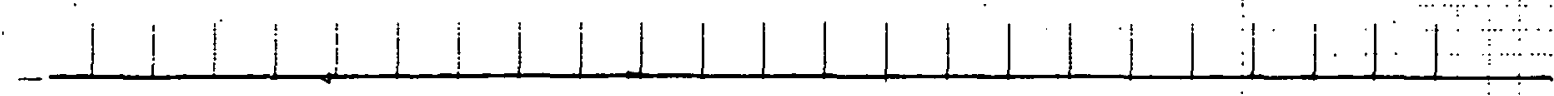




\author{
Jack Fitzer W. E. Dillon \\ University of Texas at Arlington \\ Arlington, Texas 76019
}

John Solman

MIT Lincoln Laboratory.

Lexington, Massachusetts 02173

The future advent of widespread use of residential photovoltaic power systems interactive with the utility could have a significant effect on the electrical distribution system. To evaluate these effects, case studies were conducted on particular distribution lines. The studies were based on continuous measurements of output power of a $6.5 \mathrm{kw}$ photovoltaic array and a line commutated synchronous inverter, operating interactive with the utility. A typical residential utility distribution line was also instrumented to obtain continuous records of power, reactive power and voltage on the line at the substation. Computer studies were conducted to determine the effects on this specific line, of various numbers of residential PV systems with characteristics identical to the instrumented one. Inverter power factors of 0.707 , 0.85 and 1.0 were considered. Both uniform distribution of PV systems and PV systems concentrated at the end of the line were considered.

The following areas were investigated.

1. The effect of the fundamental component of PV power systems on the distribution line.

2. The effect of PV power systems on distribution protection.

3. The effect of inverter harmonic currents on voltage harmonics.

The results of the studies on the particular distribution line showed no adverse effect of the fundamental frequency component of power from PV systems on the distribution line. For the case of $40 \%$ of the residences having PV power systems and an inverter power factor of 0.707 , the voltage at the end of the line dropped less than $1 \%$ due to the added PV systems at maximum insolation. For the same case, except a unity power factor inverter, the voltage increased $1.7 \%$ with the addition of the PV systems. An interesting result was obtained for this particular distribution line in that, for an inverter power factor of 0.85 the line voltage was essentially uneffected by the.injection of PV power. The distribution line supplying the Northeast Residential Experiment Station was also analyzed to determine the effect of the PV power systems and experimental verification obtained.

The use of residential PV systems resulted in a significant reduction in total energy from the utility system but dit not reduce the peak power demand. This was because the peak power demand did not coincide with peak solar insolation.

The studies indicated that the PV power systems presented no problems with the protection system on the distribution line studied. This is because the PV power systems behave as current sources and therefore do not contribute large amounts of short circuit current. Also, for ground faults the voltage would be very low and the inverter would be disconnected.

A computer program was developed to evaluate the effect of inverter harmonic currents on line voltage harmonics. This program includes the line, transformer and customer load impedances. The customer load impedance is estimated using the predicted customer power and a power factor of 0.86 . Results were obtained for the effect of third harmonic currents.

The draft of the final report has been completed and is being reviewed. 
FIGURE 1. ONE LINE DIAGRAM OF DISTRIBUTION.LINE

(10 MVA, $12,470 / 7200$ Volts, $3 . \Phi .$, Y connected)

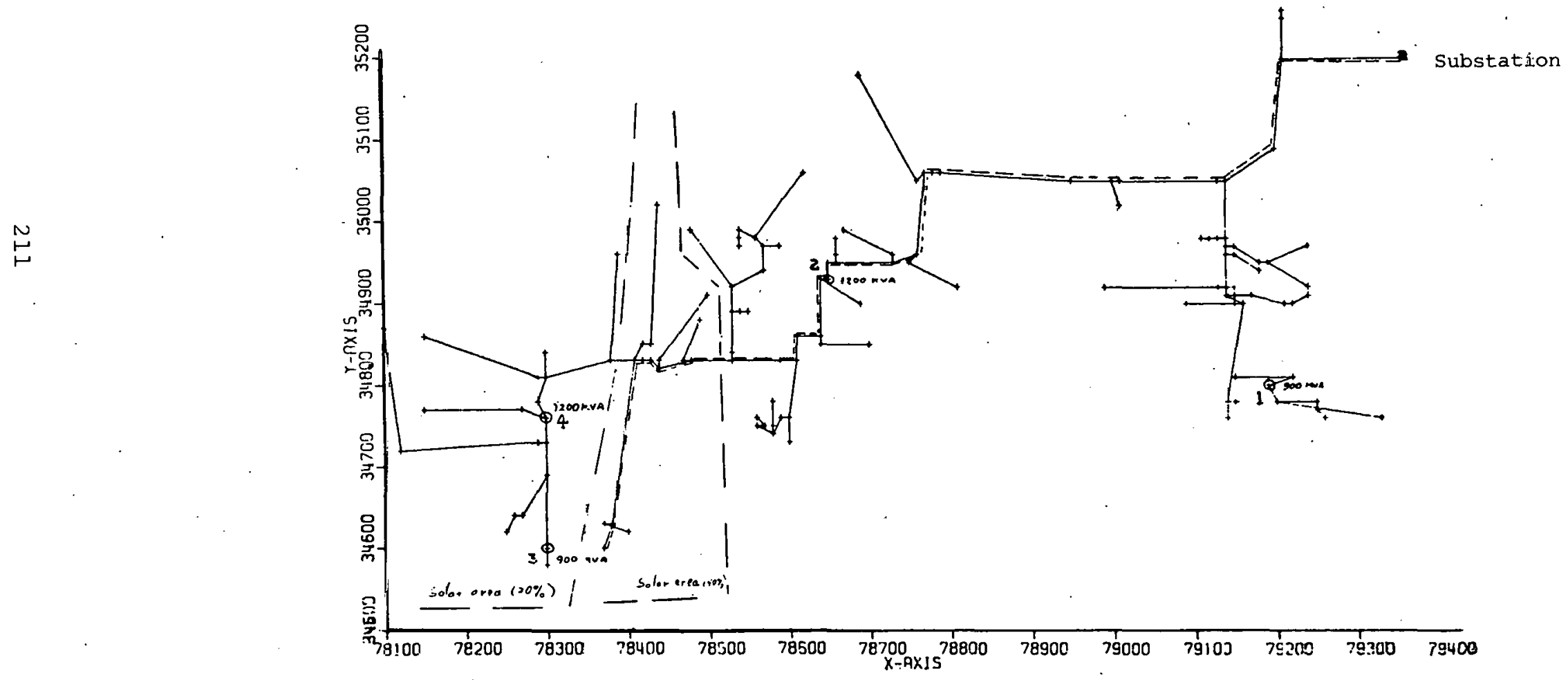


FIG. 2

SOLAR HOUSE POWER OUTPUT

THU. JULY 31.80

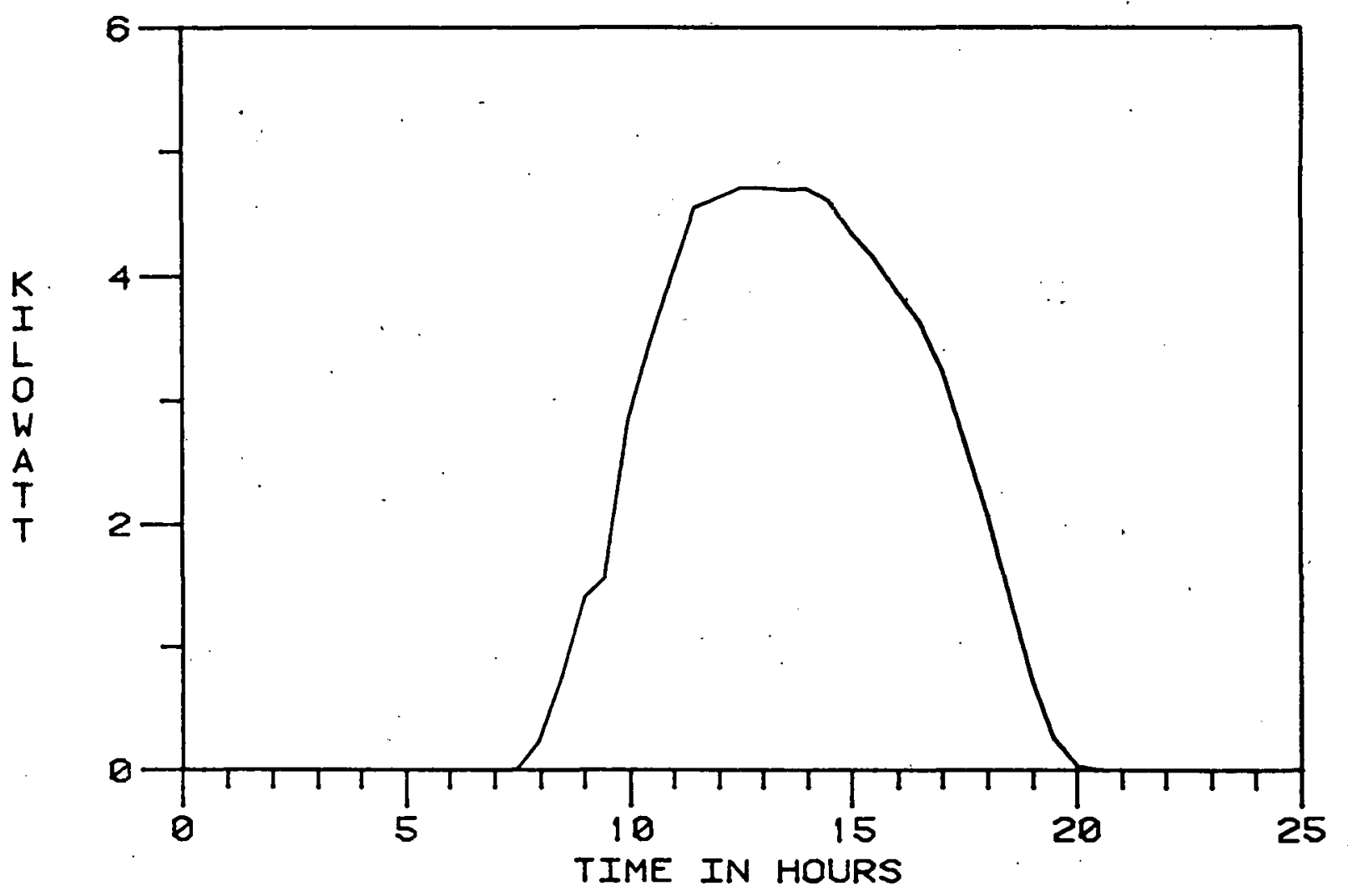


FIG. 3

DEMAND AT S.S.

THU. JULY 31.80

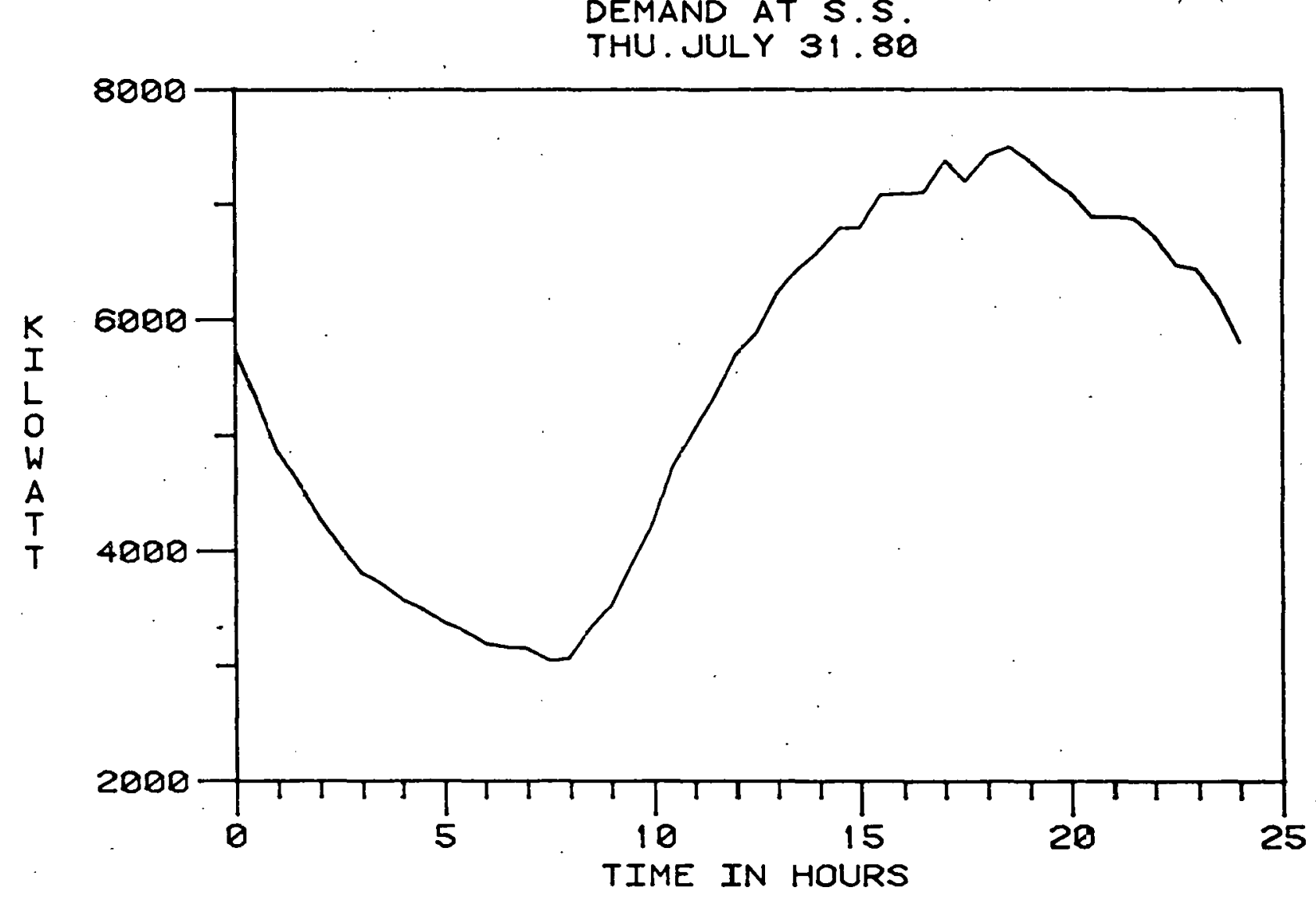




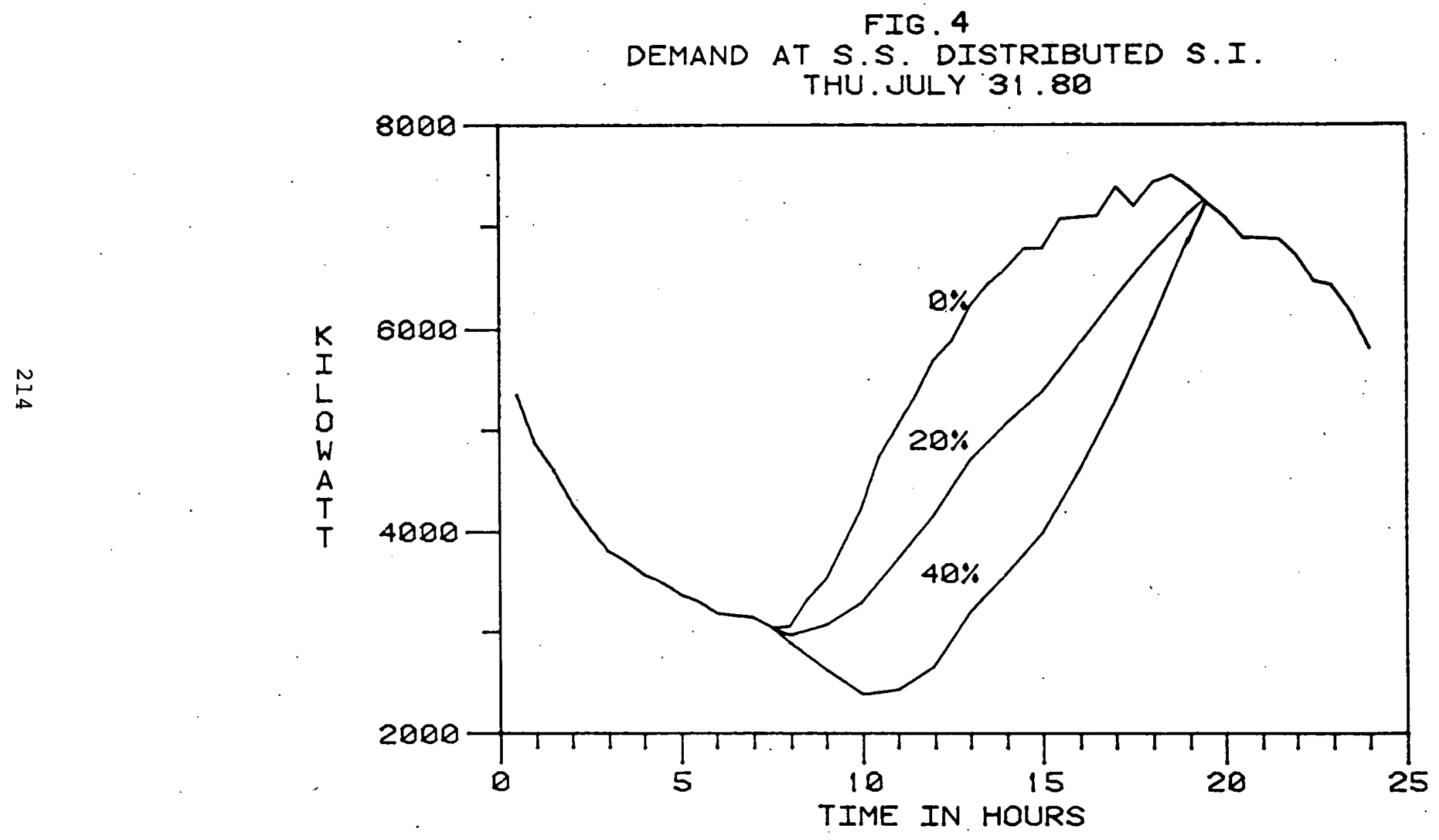




\section{FIG.5}

VOLTAGE PROFILE. DISTRIBUTED S.I. P.F. .787

THU. JULY 31.80 .14 .08

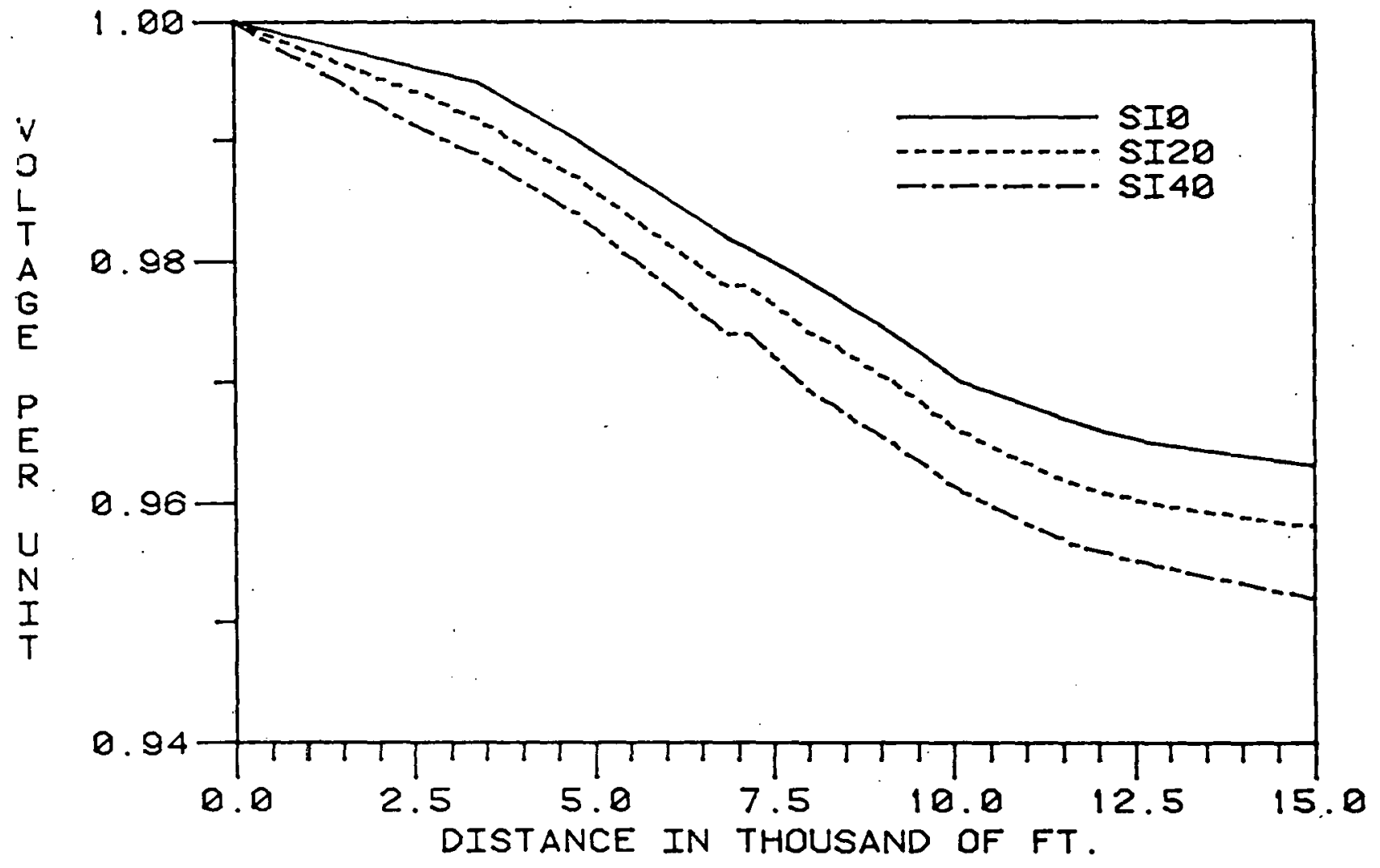




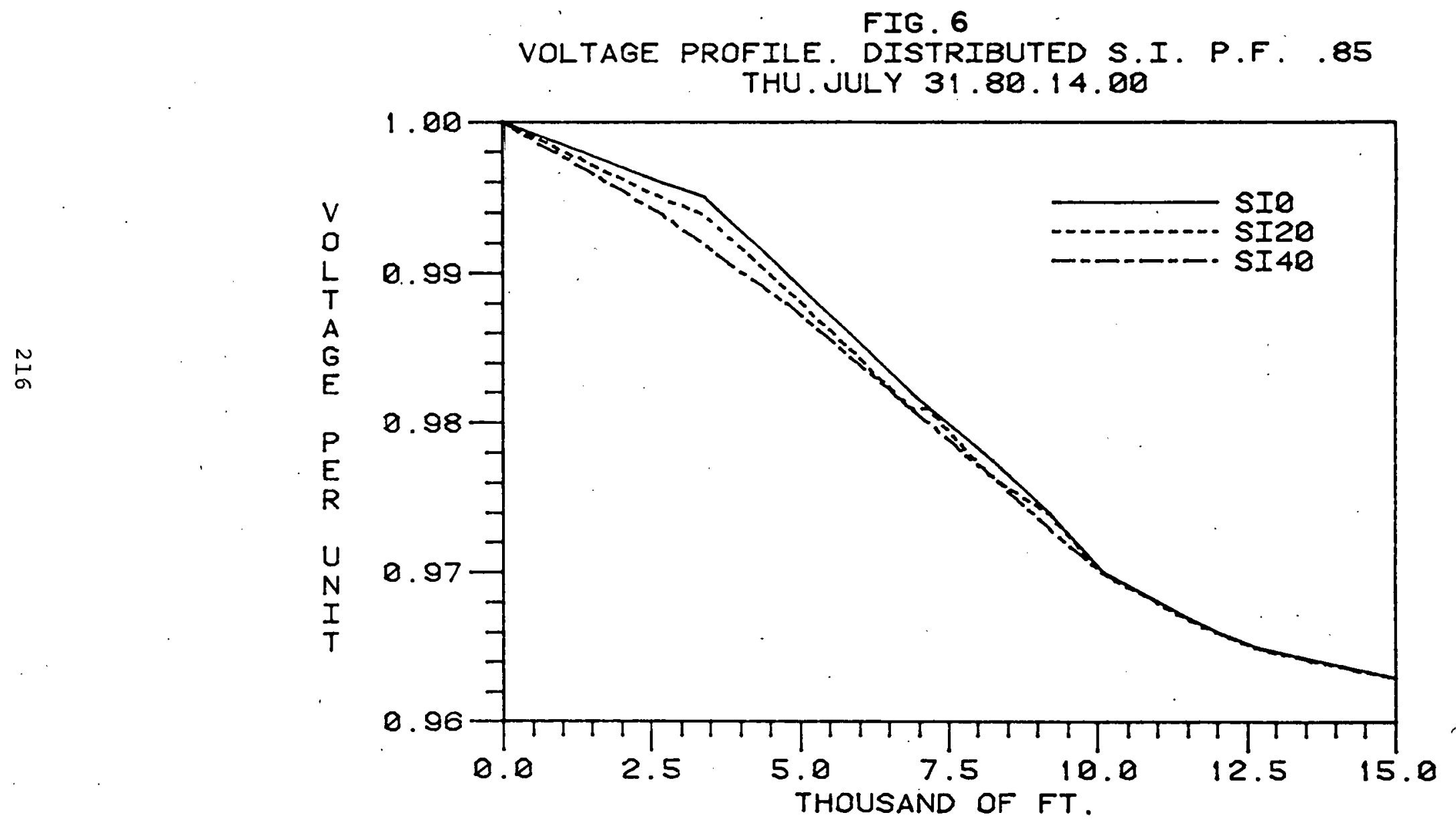


FIG. 7

VOLTAGE PROFILE. DISTRIBUTED S.I. P.F. $1 . \theta$

THU. JULY 31.80 .14 .80

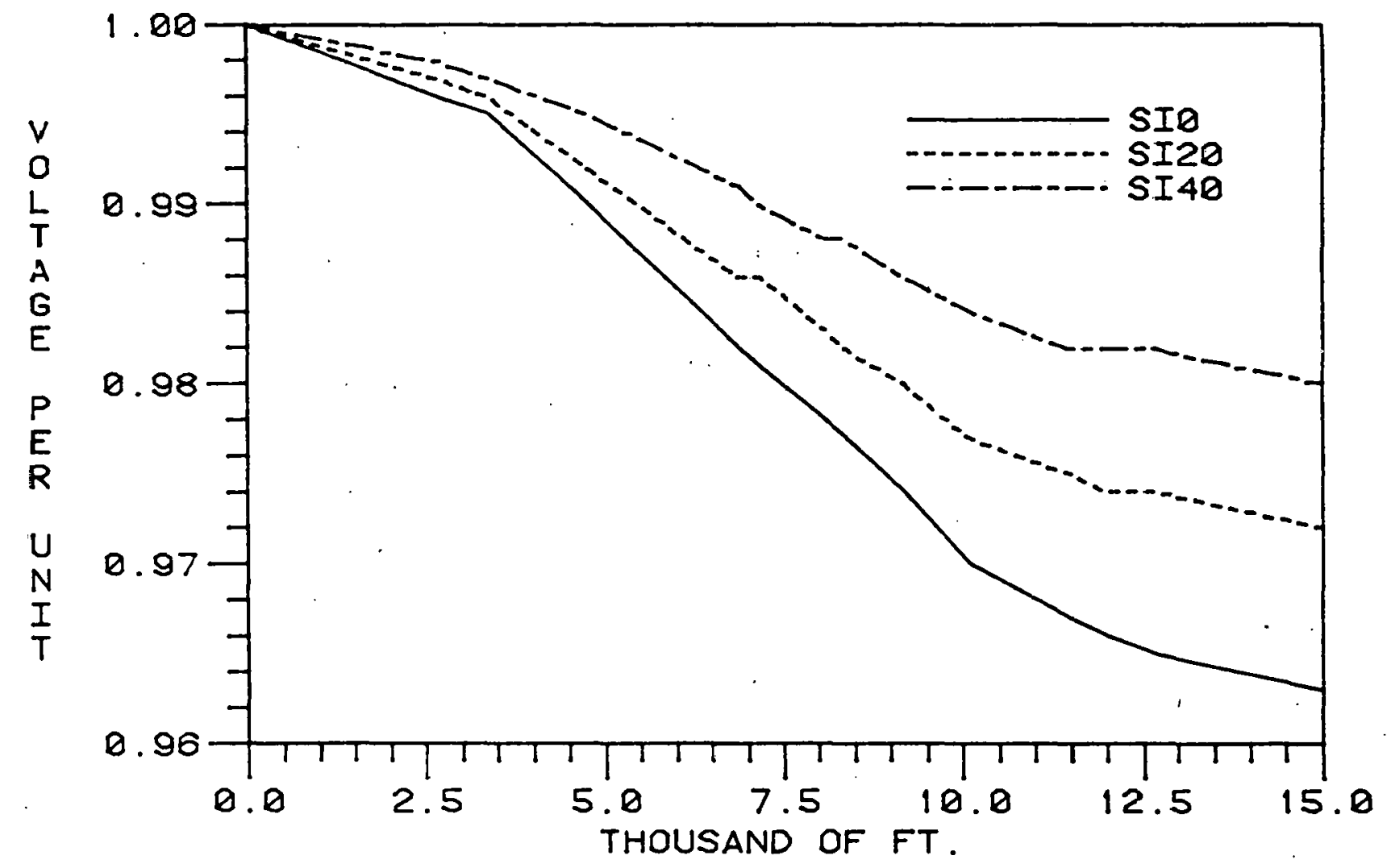


FIG. 8

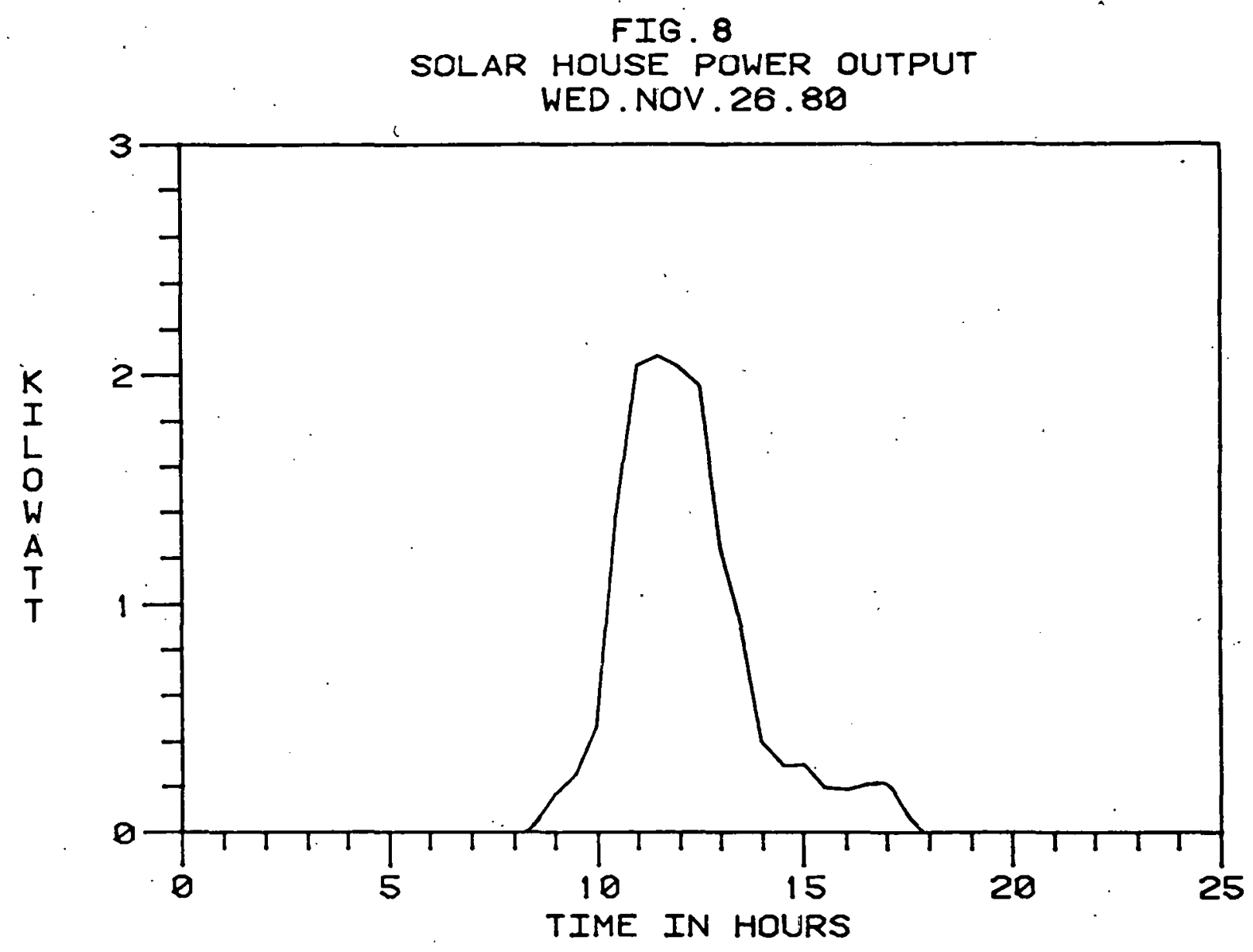


FIG. 9

DEMAND AT S.S. DISTRIBUTED SOLAR INJECTION WED . NOV . 26.80

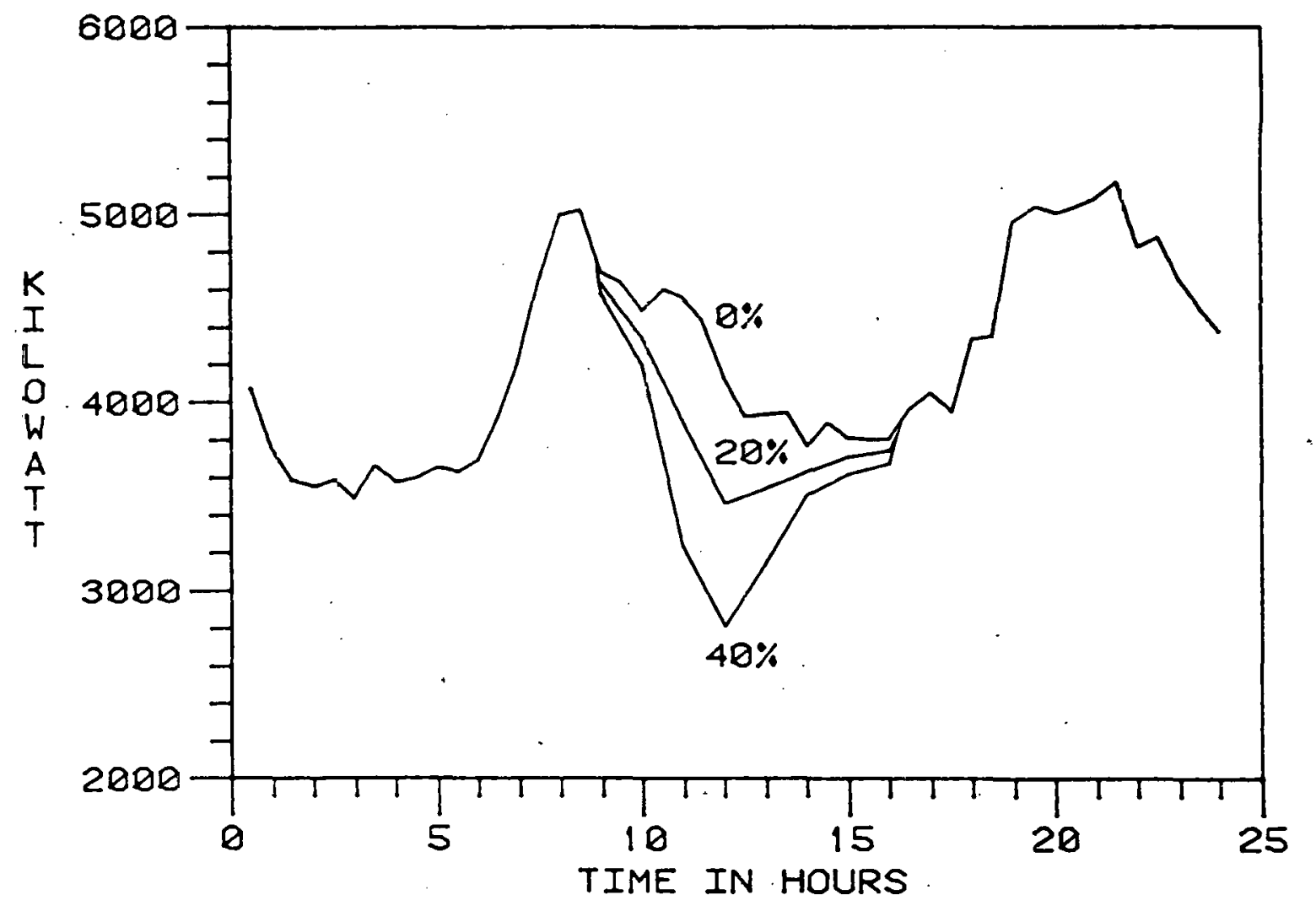


FIG 10

VOLTAGE PROFILE. DISTRIBUTED S.I. $20 \%$ WED.NOV.26.80.11.00

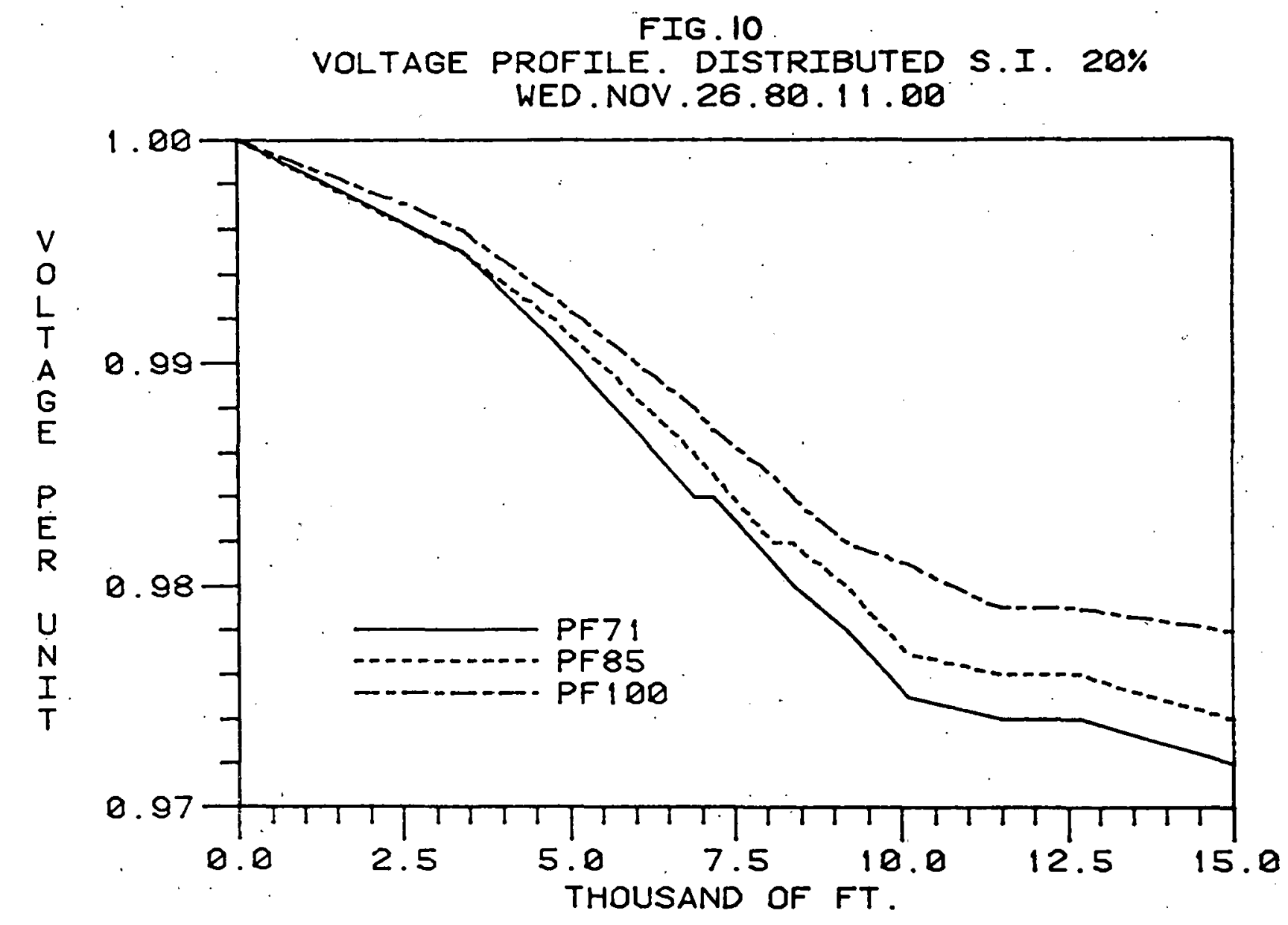


POWER-CONDITIONING SUBSYSTEM EVALUATION TEST REQUIREMENTS * * +

\author{
C. H. COX, III \\ Massachusetts Institute of Technology \\ Incoln Laboratory \\ Lexington, Massachusetts 02173
}

\title{
ABSTRACT
}

The inspections to be made, the conditions for measurement, the variables to be measured and the analysis to be performed in order to characterize the operation of a power-conditioning subsystem (PCS) are described. Of primary concern are utility-interactive PCSs in the 2-10 kW power range intended for Installation in a residential photovoltalc system and to feed a single-phase $120 / 240$ volt line.

Investigation covers four main tasks: first and second, to identify tests and procedures for characterizing PCS technical performance. Tests in the first task are constructed and conducted under conditions near the center of the range of conditions the PCS will encounter In actual usage. The second task covers testing in the extremes of conditions, i.e., the tests and conditions are possible, though not probable. Both include tests for determining the values of parameters as well as the effectiveness of control algorithms. The principle parameters to be measured include active power flow, reactive power flow, waveform analysis, electromagnetic and acoustic noise. In the control area, tests will focus on array loading control, principle operation control and auxiliary control. The dc and ac interfaces also will be tested to characterize the effects of the PCS on them.

The third task presents procedures for estimating the probability that the PCS will meet the DOE goal: 30 years of servicable operation. Since much work remains to be done to determine just what constitutes an effective procedure for establishing such probabilities, the materfal in this task is only outlined.

The fourth tasks covers a thorough examination and analysis of the PCS design, primartly in the power and control sections. The goals of this task are twofold: to uncover areas of the PCS where the design is marginal and to provide a crosscheck between predicted values and the measured values of selected parameters. Any significant descrepancies will be used to uncover areas of the PCS that rely for their operation more heavily on incidental than intentional effects.

In order to assure uniformity and to expedite measurements, tests will be conductcd with the PCS connected between array and utility simulators. Although the salient features of both the array and the utility will be duplirated by the simulators, some aspects of each will go unduplicated. Thus the final tests will operate the PCS between an actual array and utlity. This will serve both as a final cliech un PCE performance and as a completeniss check on tha falthfulness of the simulators.

The results of these tests w111 serve several purposes. Most important, they will stand as an objective assessment of PCS performance under the full range cf conditions likely to be. experfenced in an accual application. As these conditions are not generally well known and require extensive facilities to produce, most PCSs will not have been tested by their manufacturer. The test results will also provide the data base from which various figures of meter (Fon) can be calculated. These FOMs will permit meaningful comparisons to be made between PCSs that offer differenl luatures.

^ $t x$

The U. S. Government assumes no responsibllity for the work presented.

tsubmitted to the Third Photovoltalc Systems and Applications Profect Integration Meeting, 9-11 February 1982, Alhuquerque, NM. 
POWER CONDITIONING SUBSYSTEMS ENGINEERING EVALUATION PROGRAM

\author{
Ward I. Bower \\ Sandia National Laboratories \\ Division 2364 \\ Albuquerque, NM 87185
}

An Engineering Evaluation Plan (EEP) for small and medium size power conditioning subsystems (PCS) has been prepared. This plan was a joint effort of Sandia, MIT-LL-and JPL-PV lead center. It was designed to provide continuity in PCS testing and evaluation as Sandia assumes the evaluation program responsibility for small $(2-10 \mathrm{~kW})$ PCS from MIT-LL and continues the medium PCS program. The evaluation program is intended to assist the PCS manufacturing industry and PCS users by characterizing PCS technical performance in a uniform and consistent manner.

The resource requirements for the PCS evaluation progran are included in the EEP. A Photovoltaic Power Processing Evaluation Facility located at sandia is described, single- and three-phase test circuits are characterized, test and data acquisition equipment and PCS hardware to be evaluated are detailed.

As a part of the PCS program, test procedures for small and medium size PCS's will be standardized and documented. Tests necessary for verification of minimum PCS performance per the appropriate "Baseline Specification" will be conducted. Critical input and output parameters and critical control of functions will be defined and appropriate test procedures established.

The Engineering Evaluation program is intended to evaluate candidate PCS's obtained off-the-shelf acquisition as well as from the PCS advanced development program. These PCS's will then be evaluated using field arrays and PV array simulators as power sources. The PV array simulators will be used to provide controlled and convenient. inputs for testing. Limitations of array simulators will be documented. PCS characterization will occur under nominal operating conditions, dynamic conditions and under extremes of inputs, outputs and environments. 


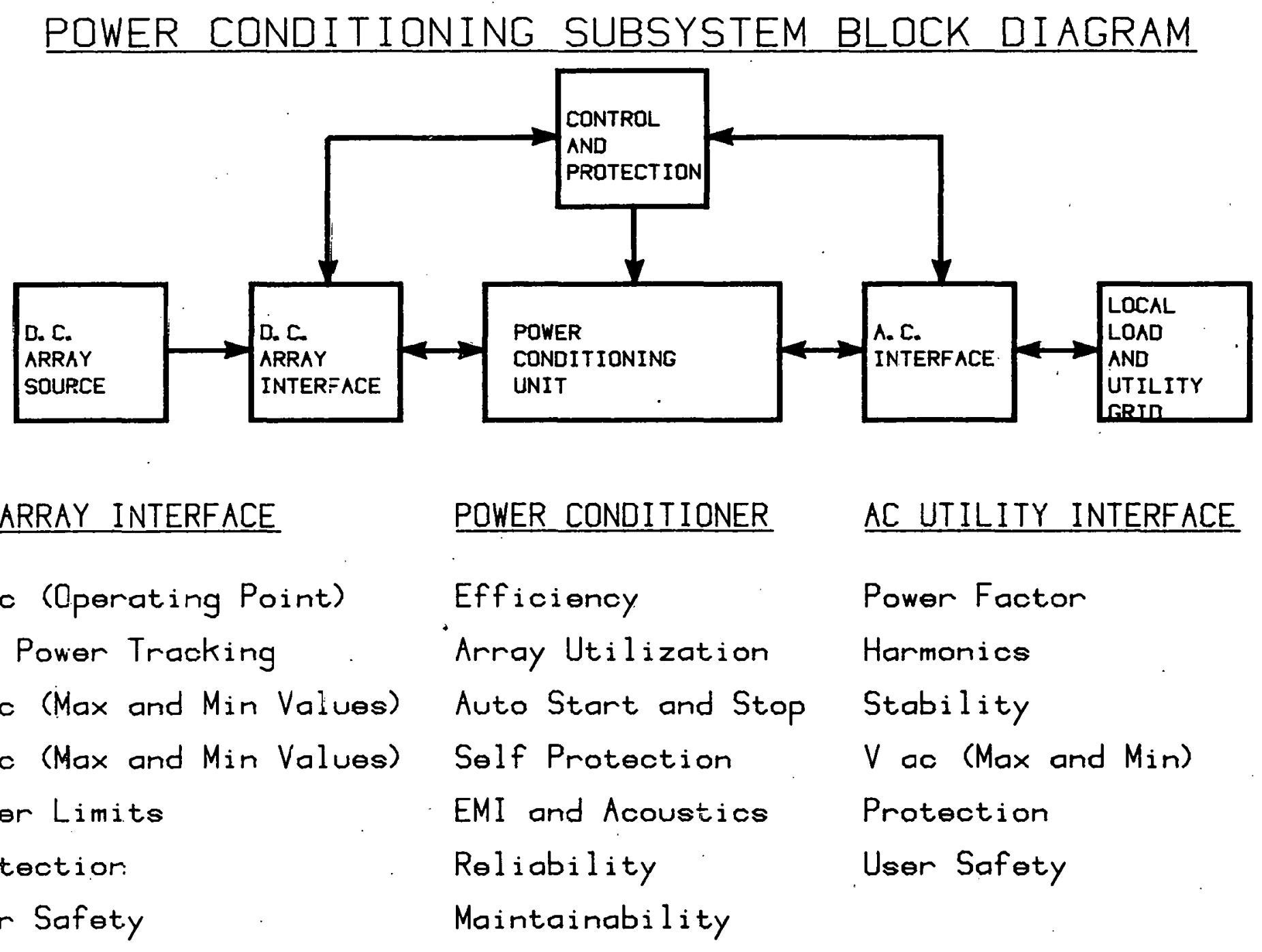




\section{PCS ENGINEERING EVALUATION PLAN}

BACKGROUND

* PV SUBPROGRAM FOR UNIFORM PCS TEST \& EVALUATION.

* joint efFort of SANDiA, JPL-PV LEAD CENTER AND MIT-LL.

PURPOSE

* PROVIDE A. pCS eVAluation pROGRAM to ASSist pCS industry.

* provide a. pCS eVAluation program to assist pCS users.

* charactefize pCS performance in a UNiform MANNER.

SCOPE

* evaluate small and medium sized pcs to minimum specs.

* provide necessary facilities, manPower and equipment.

* PŔQVIDE PES HARDWARE THROUGH DEVELOPMENT AND OFF-THE-SHELF ACQUISITIONS. 


\section{PCS ENGINEERING EVALUATION PROGRAM}

GENERAL TEST REQUIREMENTS

* standardize test procedures and provide a test procedures DOCUMENT FOR PCS TESTS AND EVALUATIONS.

* Define minimum tests to Verify performance per the BASELINE SPECIFICATION.

* DEFine cRitical inPut and OUTPUt paRAMETERS AND CONTROL FUNCTIONS NECESSARY FOR CONSISTENT EVALUATION.

* USE PV ARRAYS FOR 'REAL LiFE' tEstS AND EVALUATIONS.

* use pV arRay simulators for flexibility and convienience. 


\section{PCS ENGINEERING EVALUATION PROGRAM TEST REQUIREMENTS}

* incoming Visual hardWARE inspection (NON-OPERATIVe) (SAFETY, WORKMANSHIP. MECHANICAL LAYOUT)

* characterization under nominal operating conditions (INPUTS, OUTPUTS. PERFORMANCE)

* characterization under dynamic conditions (ARRAY SIMULATORS, LINE CONDITIONERS, STEP RESPONSES, ETC)

* characterization under extreme conditions (INPUTS, OUTPUTS, ENVIRONMENTS) 


\section{PCS ENGINEERING EVALUATION PROGRAM RESOURCE REQUIREMENTS}

FACILITIES * PHOTOVOLTAIC POWER PROCESSING EVALUATION FACILITY.

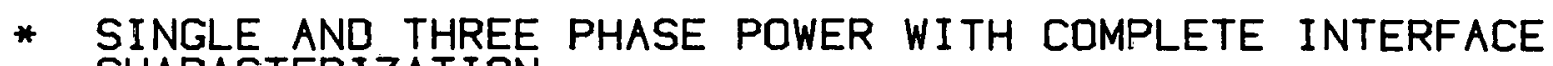
CHARACTERIZATION.

* FIELD ARRAYS CONFIGURED FOR MAXIMUM ADJUSTABLILITY.

* photovoltaic array simulators.

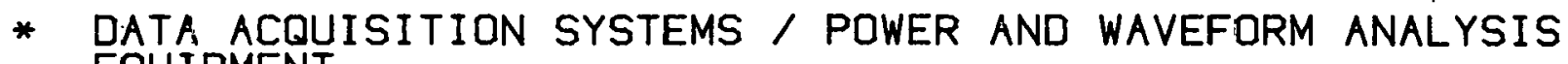
EQUIPMENT.

PCS EQUIPMENT * SMALL SIZED POWER CONDITIONING SUBSYSTEMS.

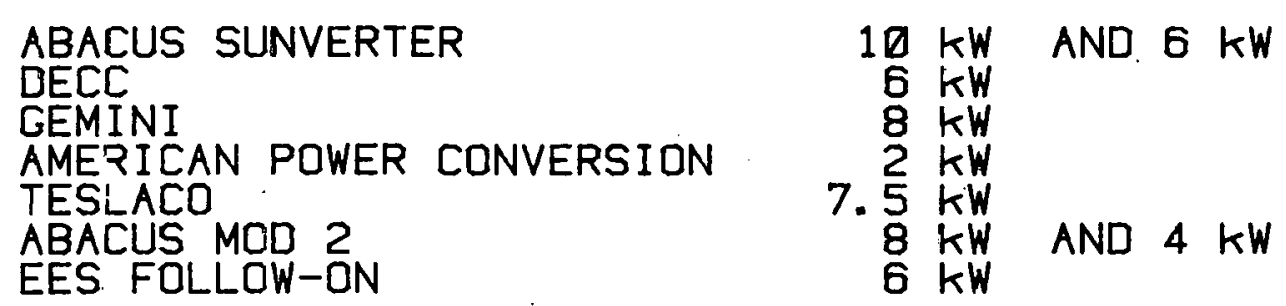

* Medium sized power conditioning SUBSyStems.
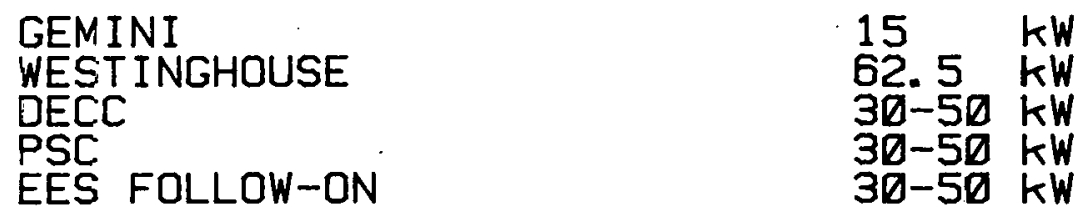
ADVANCED INTERMEDIATE-SIZE POWER CONDITIONING SUBSYSTEM

J. M. King, J. R. Vivirito, F. J. Kornbrust

UNITED TECHNOLDGIES CORPORATION

South Windsor, Connecticut 06074

United Technologies defined conceptual designs for residential and intermediate size power conditioners under U. S. Department of Energy Contract No. DE-AC02-79ET29355. The objective of the contract was to define advanced power conditioner conceptual designs which provide improved interface and economic characteristics for use with solar photovoltaic and other advanced dc sources. This presentation describes the intermediate-size unit.

An $80 \mathrm{~kW}$ inverter with transistors for the switching devices was selected for the intermediate-size design. This rating is the highest believed practical with a single near-term transistor in each switch position. The unit produces 208 volt three phase power and operates over a dc voltage range of 350 to 450 volts. The characteristics of this unit in mature production would reduce the power conditioner contribution to the cost of solar photovoltaic efficiency by 50 percent compared to currently available equipment. The design is estimated to weigh 420 pounds and occupy 9.3 cubic feet. Because intermediate-size applications are expected to be served by a dedicated secondary distribution transformer, an isolation transformer is not used.

The control logic design utilizes four 8-bit microcomputers. One microcomputer performs system control and protection functions; the others produce the gating signals to the transistor switch for each phase. The gating signals produce a pulse width modulated output which meets interface specifications. At rated power, estimated efficiency varies between 96 and 97 percent depending on input voltage. At quarter power, efficiency vanes are between 95 and 96 percent. No load losses are less than 610 watts.

The design is configured to minimize installation and maintenance requirements. All $\mathrm{dc}$ and $\mathrm{ac}$ switchgear and sensing equipment is located within the power conditioner enclosure. Mean time between failures is estimated at 20,000 hours.

The $10 \mathrm{~kW}$ and $80 \mathrm{~kW}$ designs share common control logic and power circuit approaches which will reduce development cost. 
FIGURE 1. DC INTERFACE NORMAL OPERATING PARAMETERS

\begin{tabular}{|c|c|}
\hline 0 & $\left.\begin{array}{l}\text { MAXIMUM OPERATING VOLTAGE OF } 450 \text { VDC } \\
\text { MINIMUM OPERATING VOLTAGE OF } 350 \text { VDC }\end{array}\right\} \begin{array}{l}\text { AT PEAK } \\
\text { POWER } \\
\text { POINT }\end{array}$ \\
\hline o & VOLTAGE RATIO OF $1.3: 1$ \\
\hline & $\begin{array}{l}\text { PEAK POWER TRACKING ACCURACY OF } \\
\text { BETTER THAN } 1 \%\end{array}$ \\
\hline & $\begin{array}{l}\text { RIPPLE CURRENT LIMITED TO 5\% PEAK TO PEAK } \\
\text { - } \quad \text { PROVIDES PEAK POWER UTILIZATION OF >99\% }\end{array}$ \\
\hline
\end{tabular}

FIGURE 2. DC SOURCE INTERFACE CIRCUIT DIAGRAM

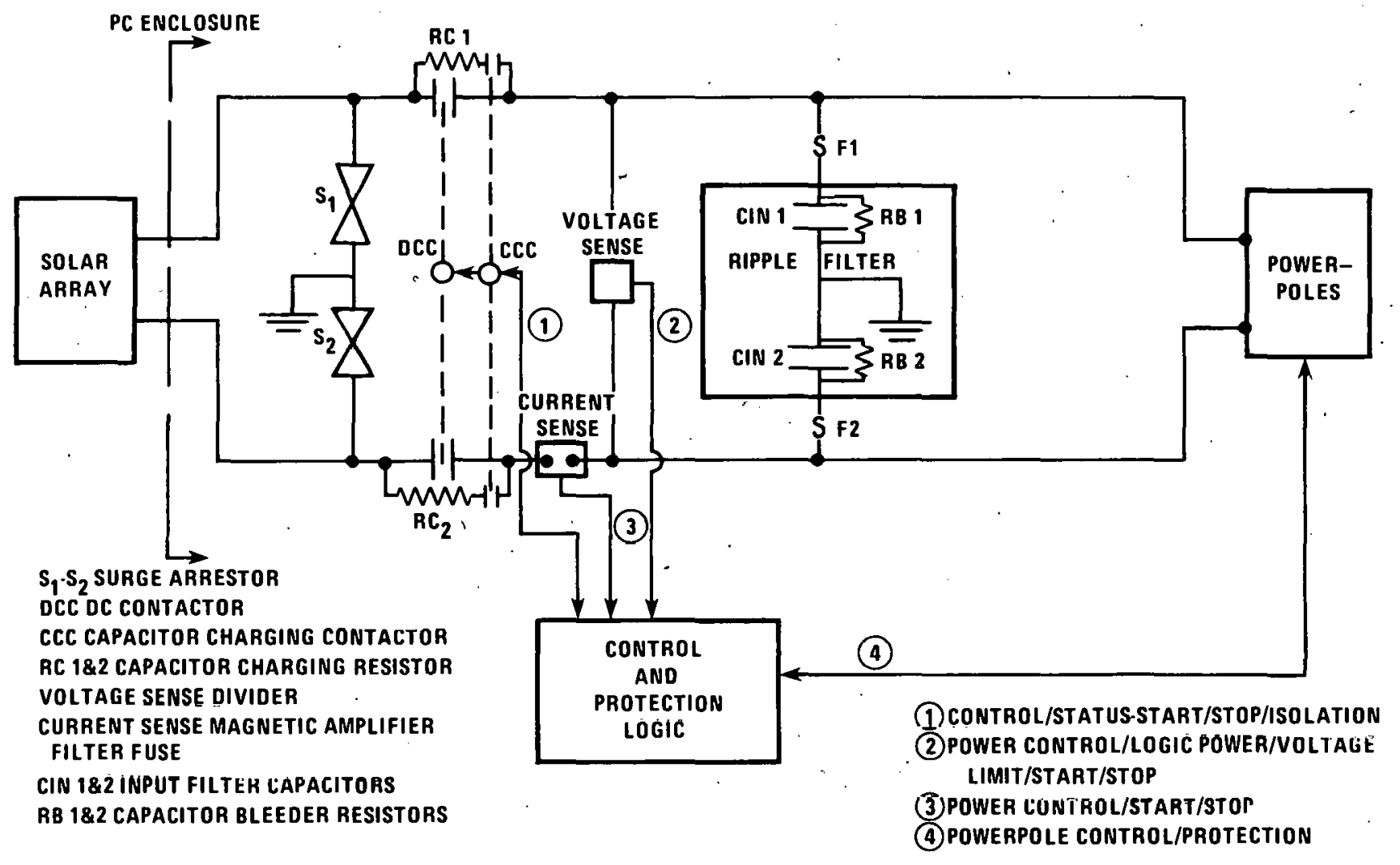

$62 \cdot 16$ 
FIGURE 3. AC INTERFACE NORMAL OPERATING CONDITIONS

0 VOLTAGE FORM AND LEVEL

- 208 VAC, THREE PHASE, 3 WIRE

- KVA RATING

- 80-kW NOMINAL REAL POWER

- MAINTAIN 1.0 OUTPUT POWER FACTOR \pm 0.05

- ALLOWABLE HARMONICS AT UTILIZATION LEVEL

- MAXIMUM OF 5\% TOTAL VOITAGE HARMONIC DISTORTION

- MAXIMUM OF 3\% ANY SINGLE VOLTAgE haRMONIC

- MEASUREMENTS MADE INTO STANDARD IMPEDANCE

- UTILITY LINE VOLTAGE

- OPERATE at full power to $\pm 10 \%$

- ALLOWABLE FREQUENCY 57 to 61 HERTZ

- TELEPHONE INTERFERENCE FACTOR $\leq 300$ BASED ON 1935 WEIGHTING . CURVE

- EMI NOT TO BE DETRIMENTAL TO EQUIPMENT OPERATING WITHIN 6 FEET (RADIATED) OR TO EQUIPMENT IT POWERS (CONDUCTED). 
FIGURE 4. AC INTERFACE CIRCUIT DIAGRAM

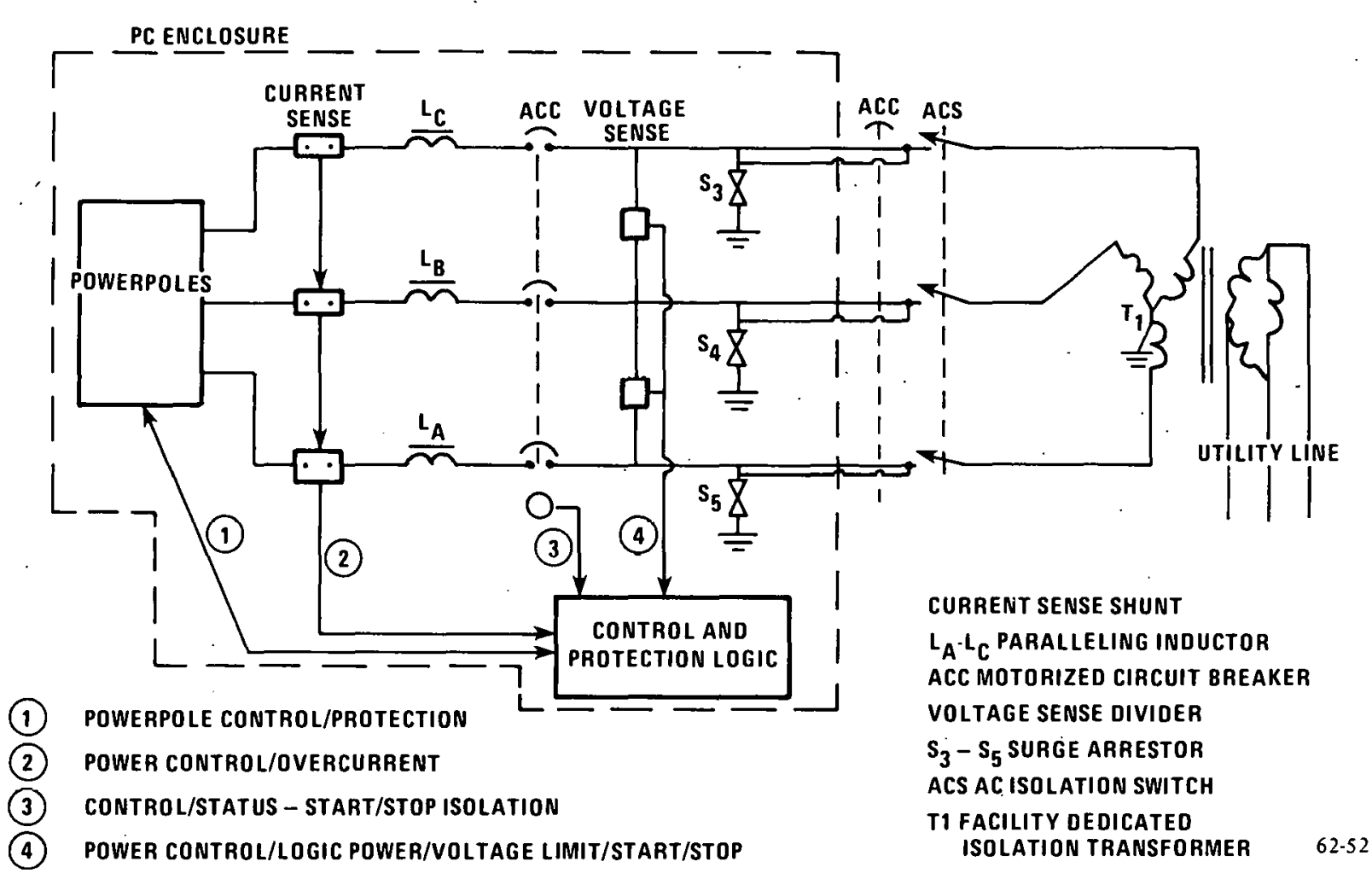


FIGURE 5. $80 \mathrm{~kW}$ POWER CONDITIONER POWER CIRCUIT

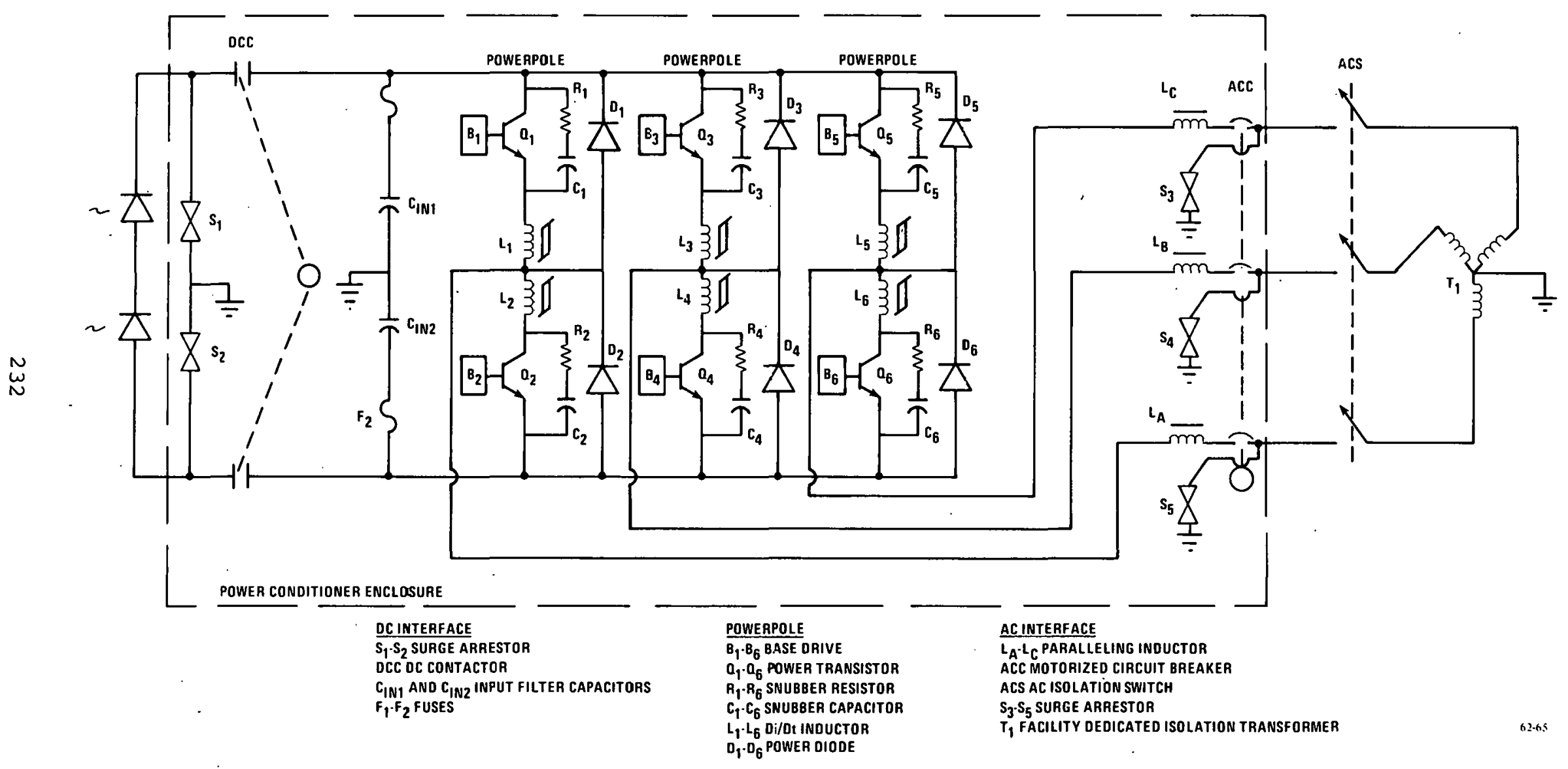


FIGURE 6. $80 \mathrm{~kW}$ POWER CONDITIONER CONTROLS

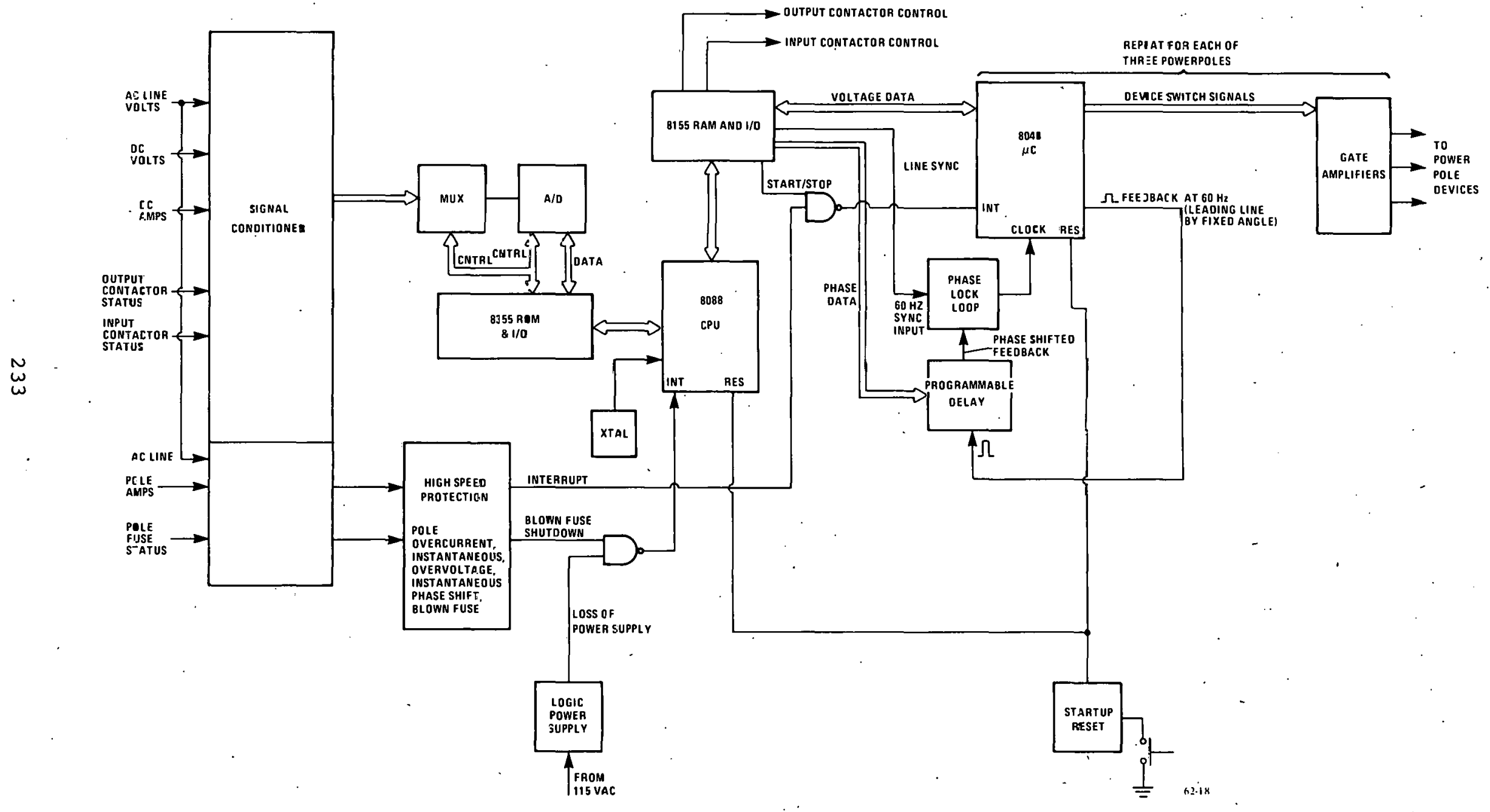


FIGURE 7." $80 \mathrm{~kW}$ POWER CONDITIONER ARRANGEMENT

FRONT VIEW

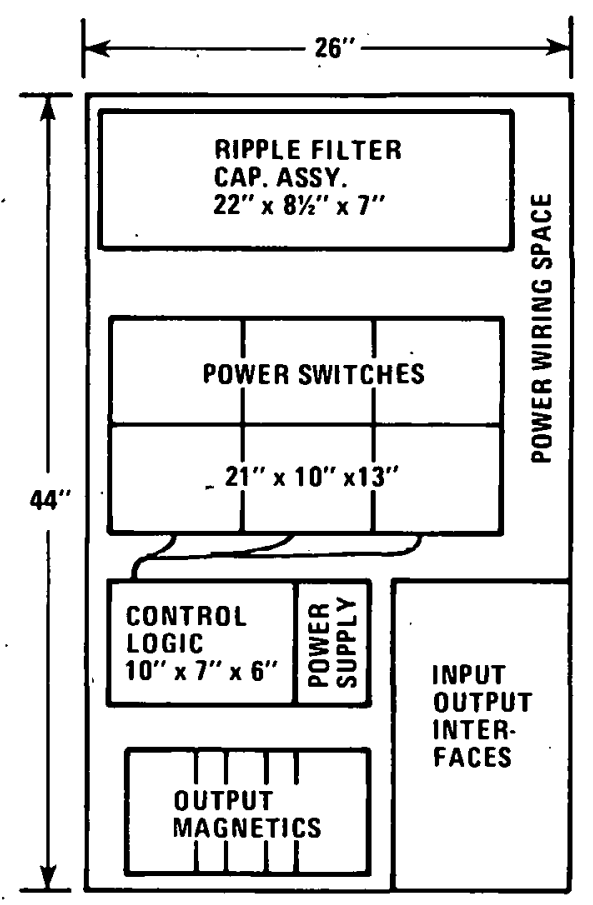

SIDE VIEW

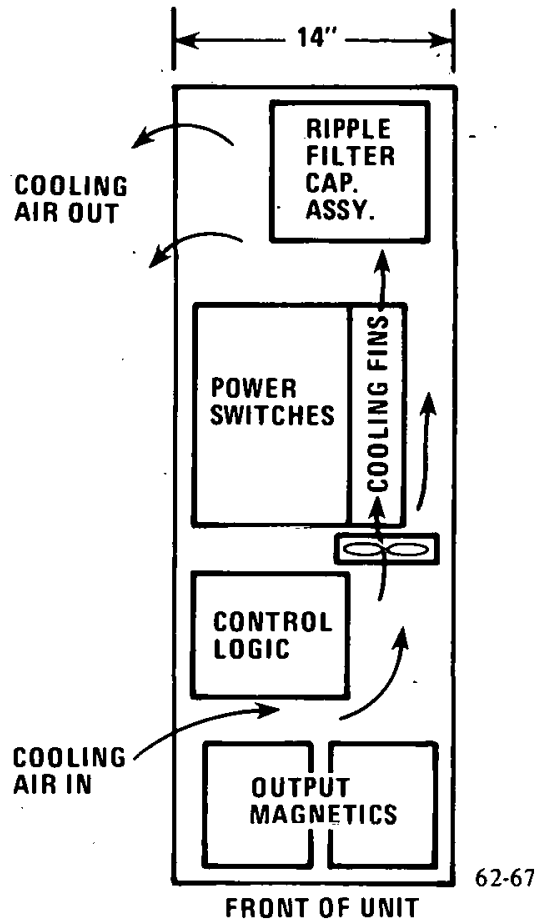


FIGURE 8. EFFICIENCY COMPARISONS

$$
\begin{gathered}
\text { ESTIMATE } \\
\text { DOE GOAL FOR CONCEPTUAL DESIGN }
\end{gathered}
$$

\begin{tabular}{lrll}
\hline EFFICIENCY - (\%) & & & \\
RATED POWER & 95 & 95.7 & TO 96.8 \\
HALF POWER & 92 & 95.6 & TO 96.7 \\
QUARTER POWER & & 94.6 & TO 96.2 \\
NO TARE LOSSES (WATTS) & $<1600$. & 465 TO 610
\end{tabular}

FIGURE 9. COMPARISON OF CHARACTERISTICS

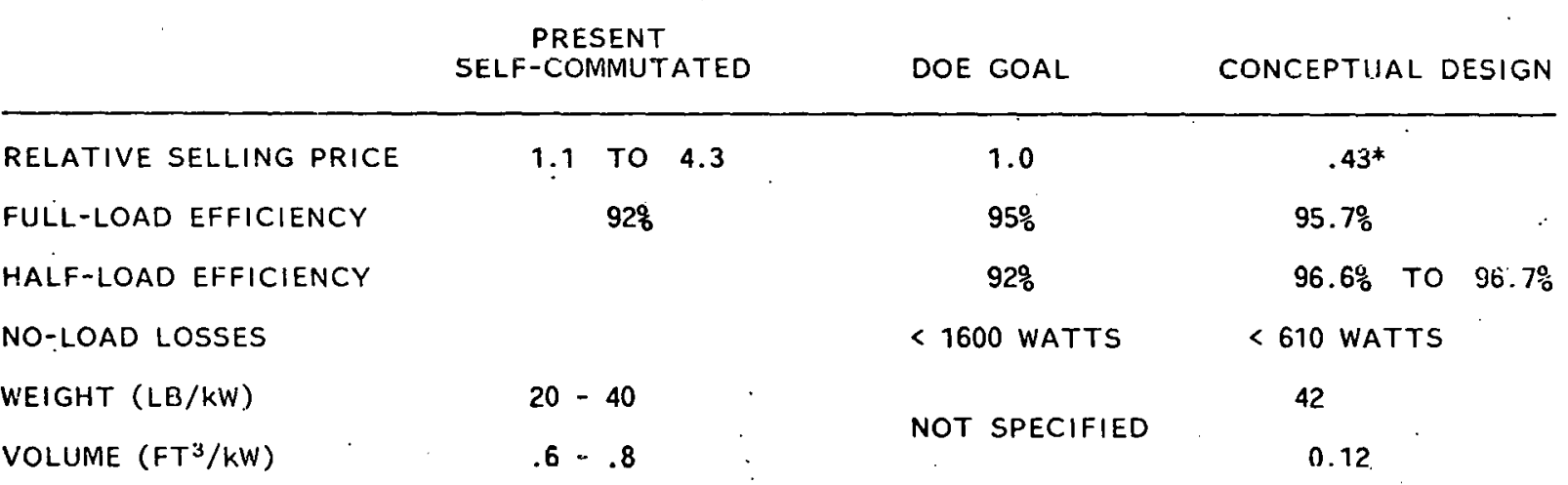

* not including sWitchgear, estimated for 1000 unit/year volume 


\section{INVESTIGATION OF A FAMILY OF POWER CONDITIONERS INTEGRATED INTO THE UTILITY GRID \\ Thomas P. Prouty \\ The Garrett Corporation \\ Torrance, Ca. 90509}

Solar energy may be indirectly stored by transferring it to a utility grid, thereby displacing the need for fossil or other fuels. This transfer process requires that power conversion units having suitable characteristics.be available at reasonable cost. The work performed under this study addresses this need by first studying the characteristics of the $A C$ and $D C$ interfaces and then selecting suitable power circuit configurations for low and intermediate power level applications. Finally, two conceptual designs were developed and their performance and costs were predicted.

The AC interface study was performed by PSEGG Research Corporation and was divided into two parts: a residential part at $120 / 240$ volts single phase and an intermediate part at $277 / 480$ volts three phase. Both steady state and transient properties of each interface were quantified. The interfaces were also defined as to the characteristics of the items delivered to the power conditioners as well as their tolerance to disturbances produced by the power conditioner. In many cases actual test data was available but in others, industry standards, tariff regulations, or consensus opinions were used.

The DC interface characteristics were obtained from previous studies and photovoltaic cell manufacturer's data. The DC voltage range was found to extend from 0.81 P.U. at $+45^{\circ} \mathrm{C}$. Wi th no wind to 1.64 P.U. at $-10^{\circ} \mathrm{C}$. wi th a $10 \mathrm{~m} / \mathrm{s}$ wind and no load. The no load condition must be considered in power conditioner design since the utility may not always be receptive.

For residential service, a power rating of $8 \mathrm{KW}$ was selected based on typical roof area and cell efficiency. At this rating transistors are readily available which inherently offer the advantages of -self commutation and fast response to fault conditions. A voltage fed approach was therefore selected with high frequency pulse modulated switching for low order harmonic suppression. A $3 \mathrm{KHz}$ basic frequency is used. Higher order harmonics are suppressed by means of a small low pass filter terminated by a shunt capacitor; the utility is tolerant to the presence of this capacitor (60 mfd.) without the need for additional switches. Because of the high speed capability of a transistor based design, the inverter can operate satisfactorily in parallel with the utility with only a small amount of series inductance; this inductance is provided by the leakage reactance of the coupling tranformer.

The conceptual design operates at rated load with an efficiency of $90 \%$. The overall dimensions are $14 \mathrm{w} \times 11 \mathrm{~d} \times 60 \mathrm{~h}$ with a weight of 311 pounds. Cooling is by natural convection. The MTBF, computed per MIL-HDBK $217 \mathrm{C}$, Notice 1 , at $55^{\circ} \mathrm{C}$. is 28,483 hours. Large quantity production prices are estimated to be approximately $\$ 2000$ per unit (June 1981 dollars).

For load center service, a rating of $200 \mathrm{KW}$ was selected to optimize the specific cost of the power conditioner. At this rating thyristors are the most economical switching element. Rather than use forced commutation with its cost and efficiency penalties, a line commutated approach was used with current feed limit the rate of rise of fault currents and thereby obviate the necessity for fast switching. Harmonics are controlled by an output filter with a large shunt capacitor. Reactive power is controlled by a parallel connected VAR generator. Harmonic voltage distortion is under $3 \%$.

The conceptual load center design operates at rated load with an efficiency of $94 \%$. Forced air cooling is employed. The overall dimensions are $120 \mathrm{w} \times 33.5 \mathrm{~d} \times 107 \mathrm{~h}$ (including air outlets). The weight is 8433 pounds. The MTBF, computed as above, is 9870 hours. In 1981 dollars, a price of $\$ 47,700$ per unit is expected. 

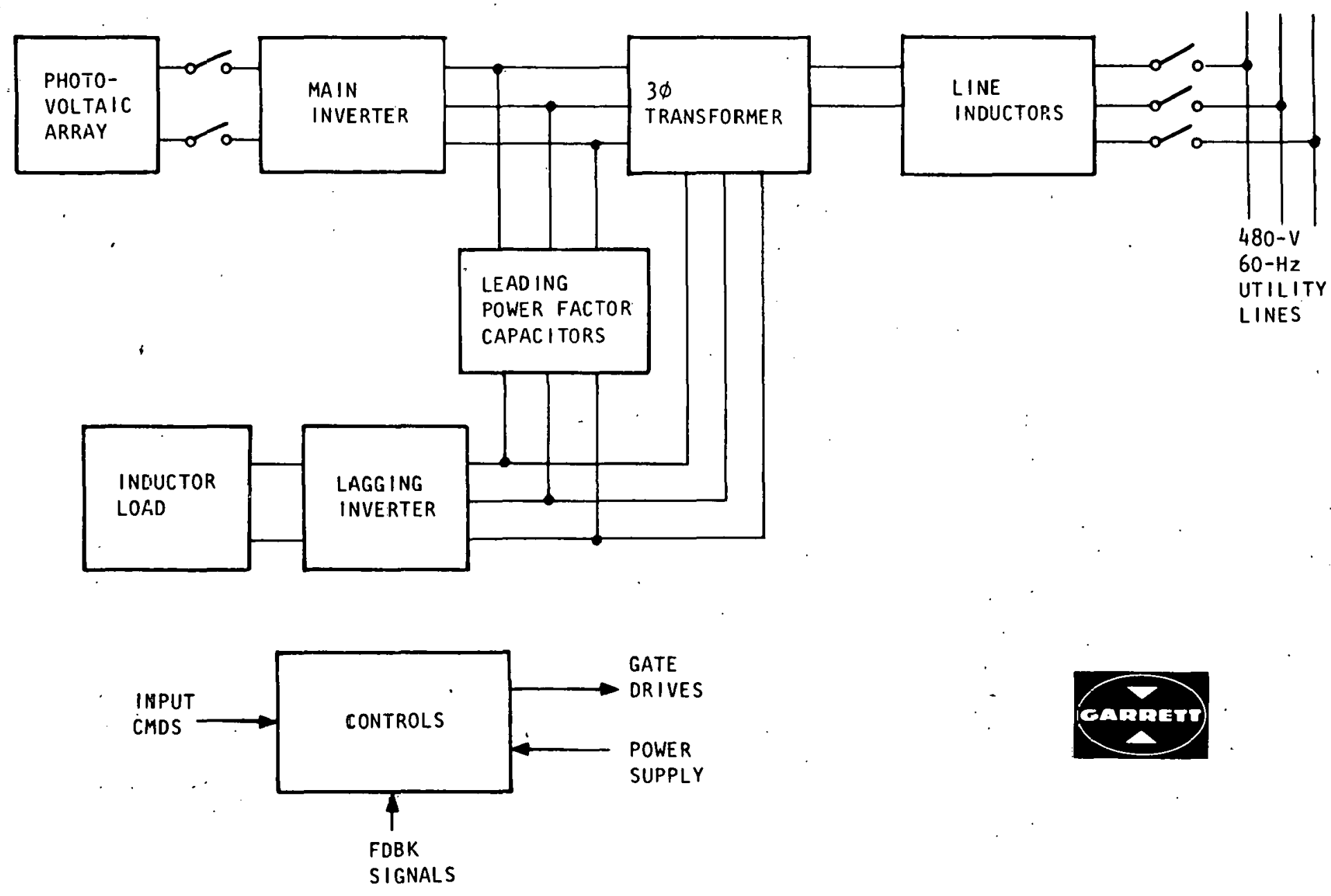

Conceptual Block Diagram

FIGURE 1 


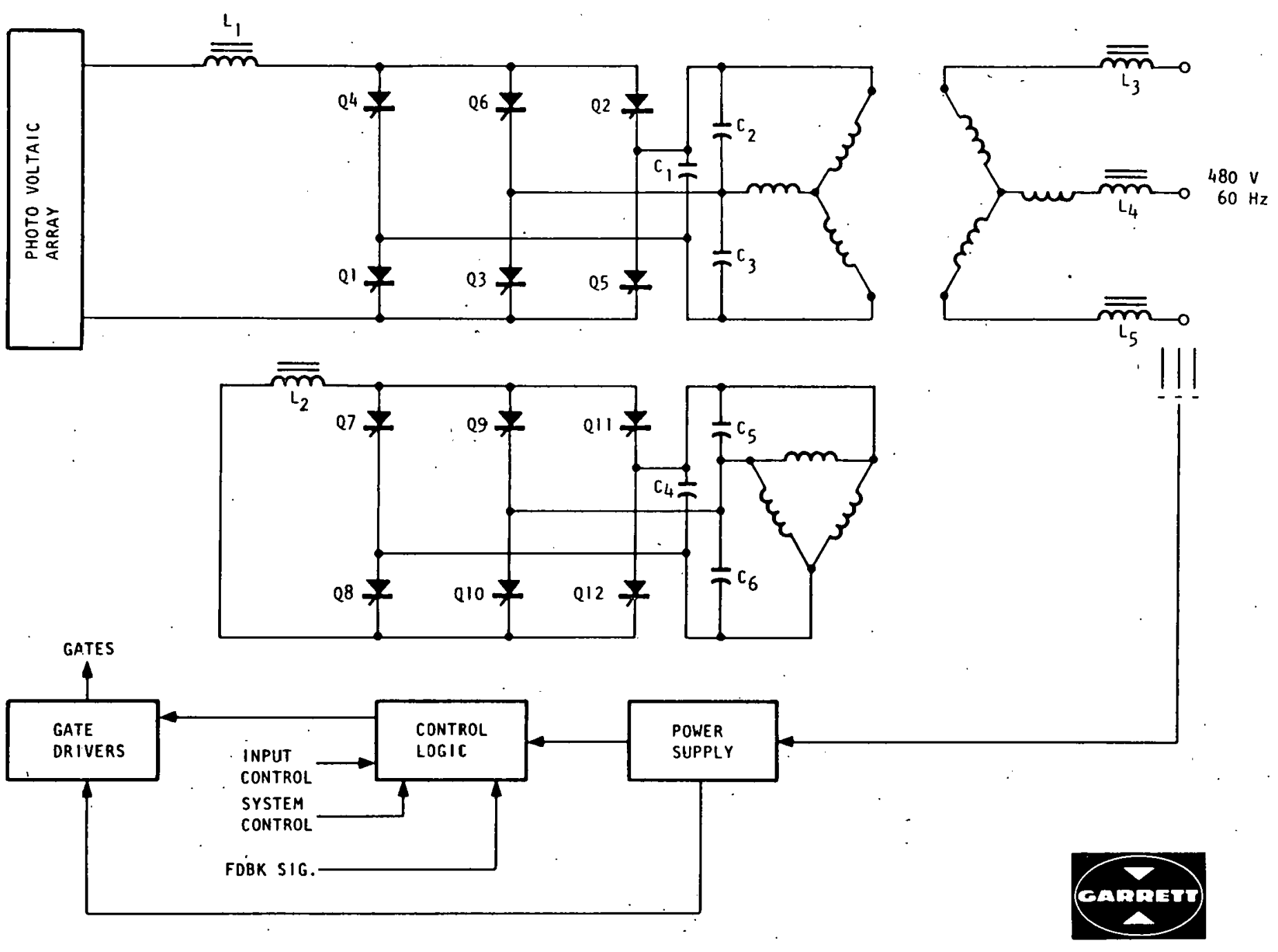

Basic Power Circuit

FIGURE 2 


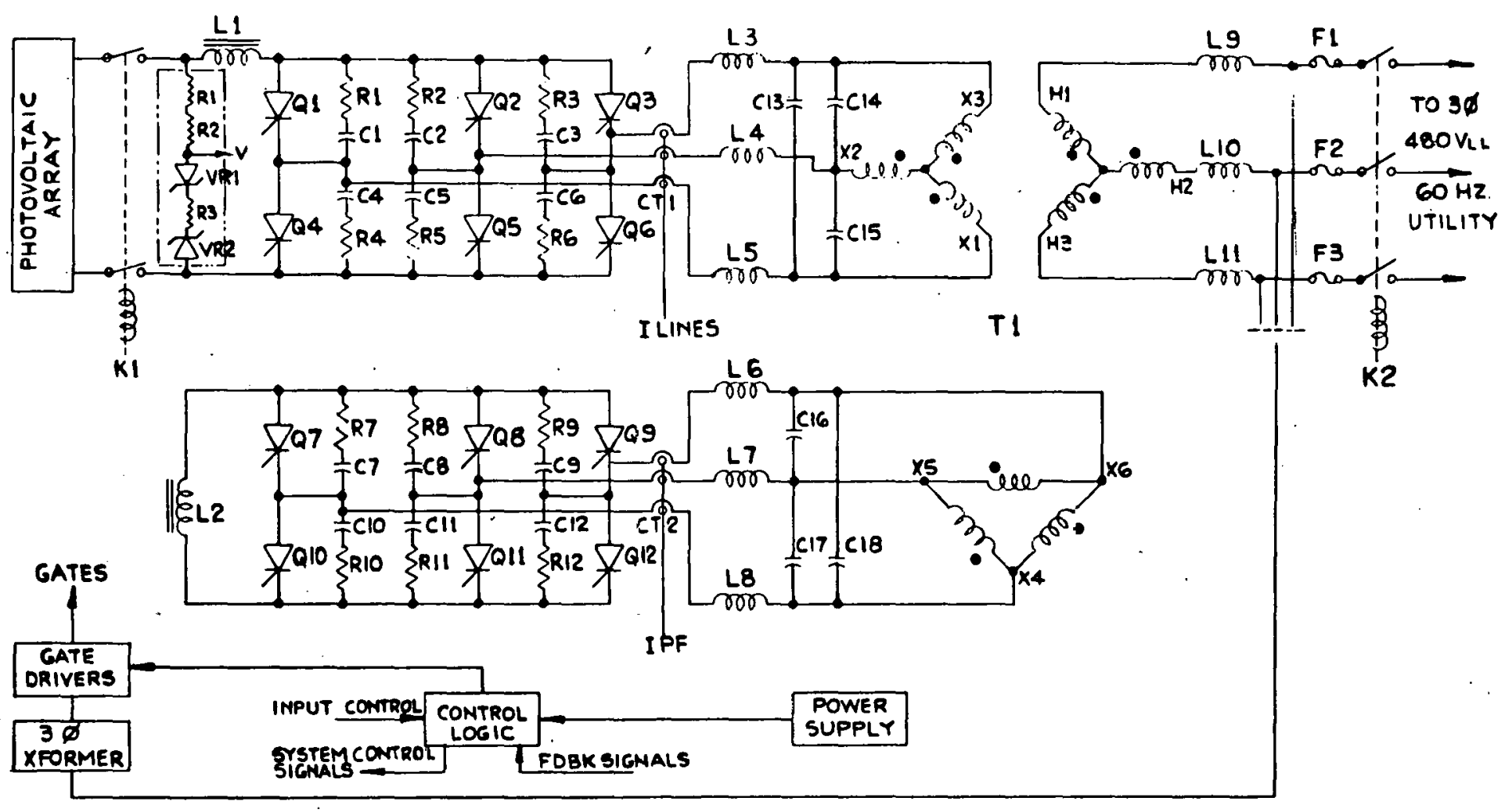

SCHEMATIC DIAGRAM; 200 INA CONCEPTUAL INNERTER

FIGURE 3 


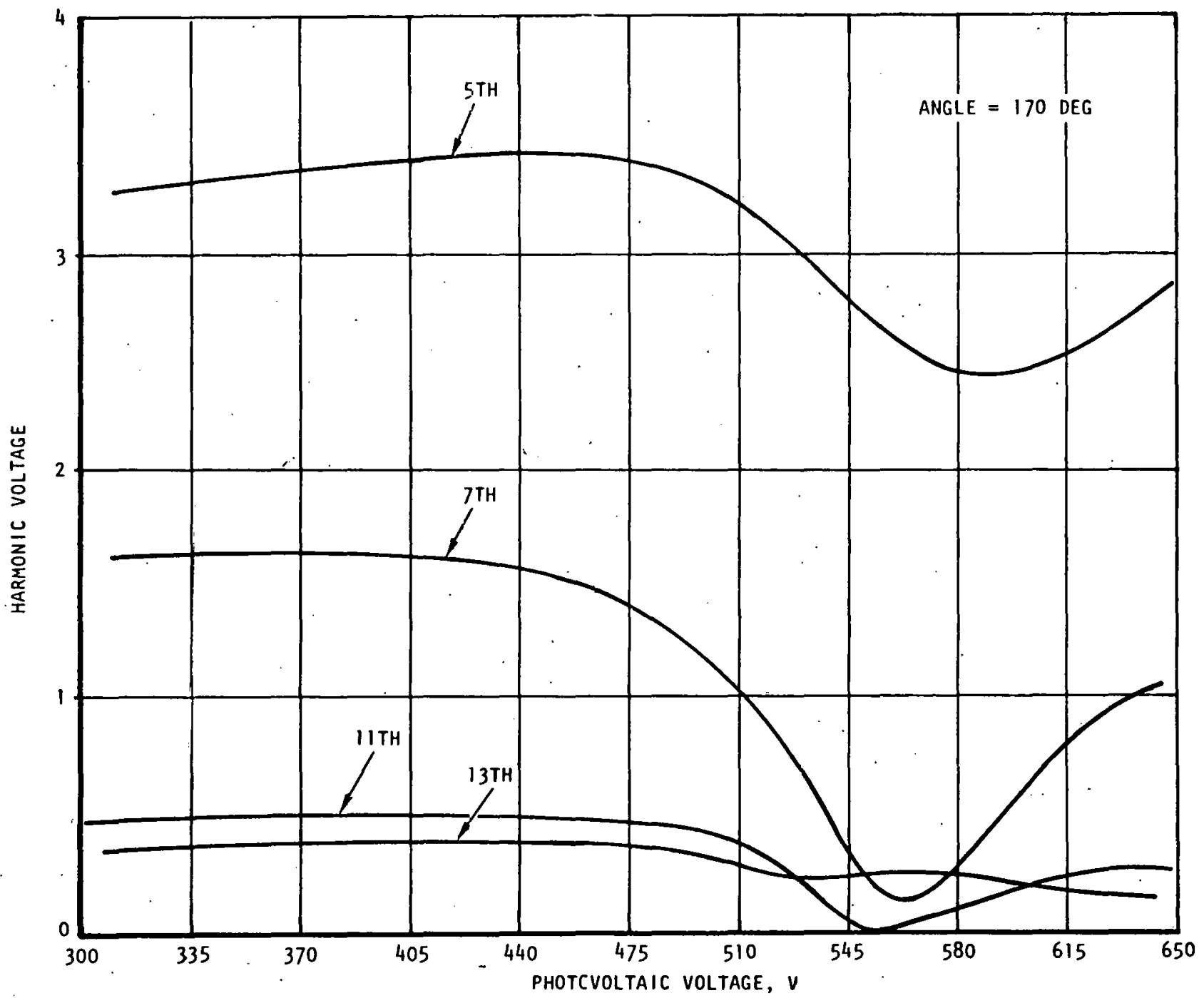

Harmonics 5, 7, 11 and 13 at Inverter Output Voltage $=291 V_{L N}$ FIGURE 4 


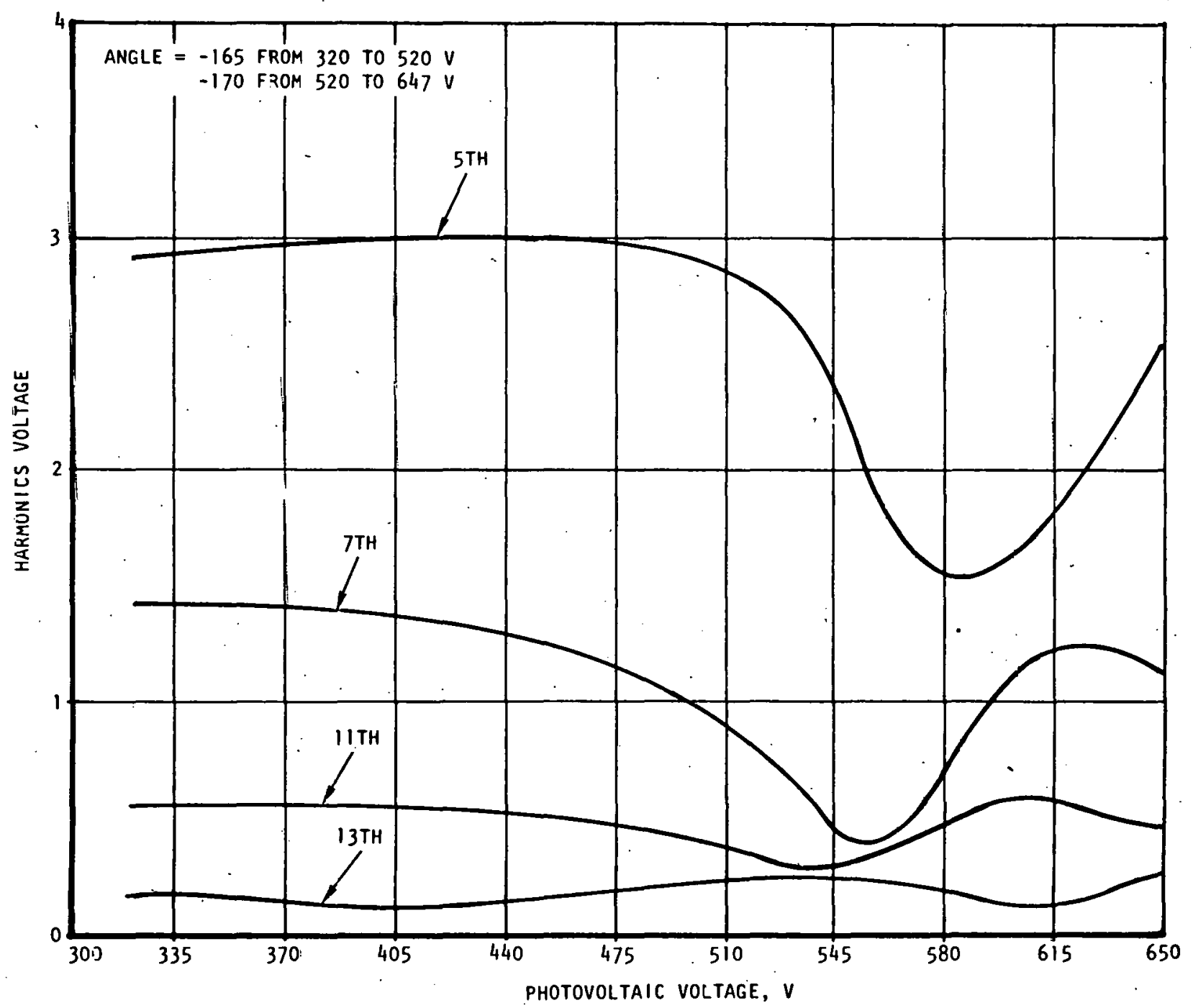

Harmonics 5, 7, 11, and 13 at

Inverter Output voltage $=263 V_{L N}$

FIGURE 5 


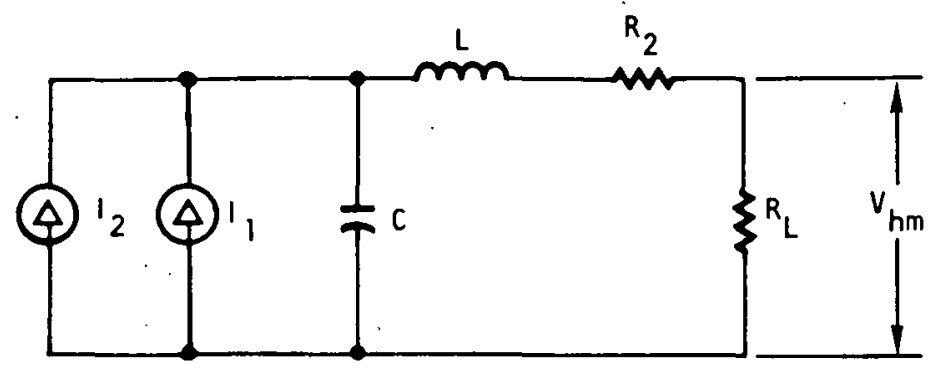

Equivalent Circuit of Output Filter

FIGURE 6

FAILURE RATE SUMMARY FOR CONCEPTUAL INVERTER

\begin{tabular}{|c|c|c|c|c|}
\hline Item & Part or Assembly & Quantity & $\begin{array}{l}\text { Part Fail ure } \\
\text { Rate Per } 10^{6} \mathrm{Hr}\end{array}$ & $\begin{array}{l}\text { Total Failure } \\
\text { Rate Per } 10^{6} \mathrm{Hr}\end{array}$ \\
\hline 1 & Inductor & 11 & 0.027 & 0.30 \\
\hline 2 & Capacitor & 14 & 0.66 & 9.24 \\
\hline 3 & Transformer & -7 & 0.10 & 0.70 \\
\hline 4 & Contactor & 3 & 2.0 & 6.00 \\
\hline 5 & Fuse & 3 & 0.1 & 0.3 \\
\hline 6 & Thyristor & 12 & 0.7 & 8.4 \\
\hline 7 & Resistor (wire wound) & 14. & 0.12 & 1.68 \\
\hline 8 & Gate driver assembly & 12 & 2.64 & 31.68 \\
\hline 9 & Control logic assembly & 5 & 2.42 & 12.11 \\
\hline 10 & Blower assembly & 2 & 12.0 & 24.0 \\
\hline \multirow[t]{2}{*}{11} & \multirow[t]{2}{*}{ Power supply assembly } & \multirow[t]{2}{*}{1} & 6.9 & 6.9 \\
\hline & & & \multicolumn{2}{|r|}{$\begin{array}{l}101.31 \times 10^{-6} \\
9870 \mathrm{hr}\end{array}$} \\
\hline
\end{tabular}

FIGURE 7 

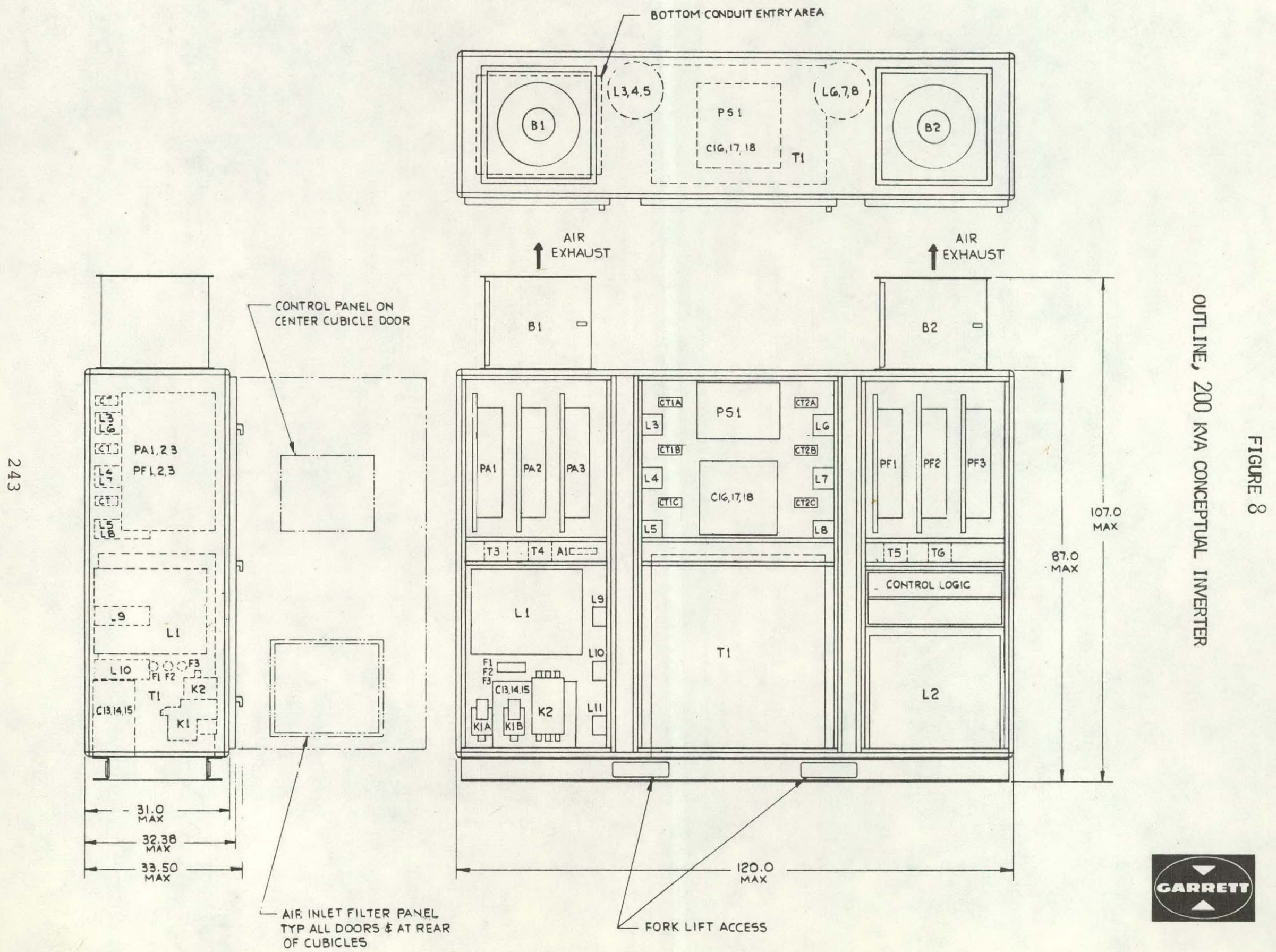

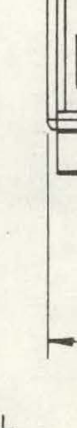

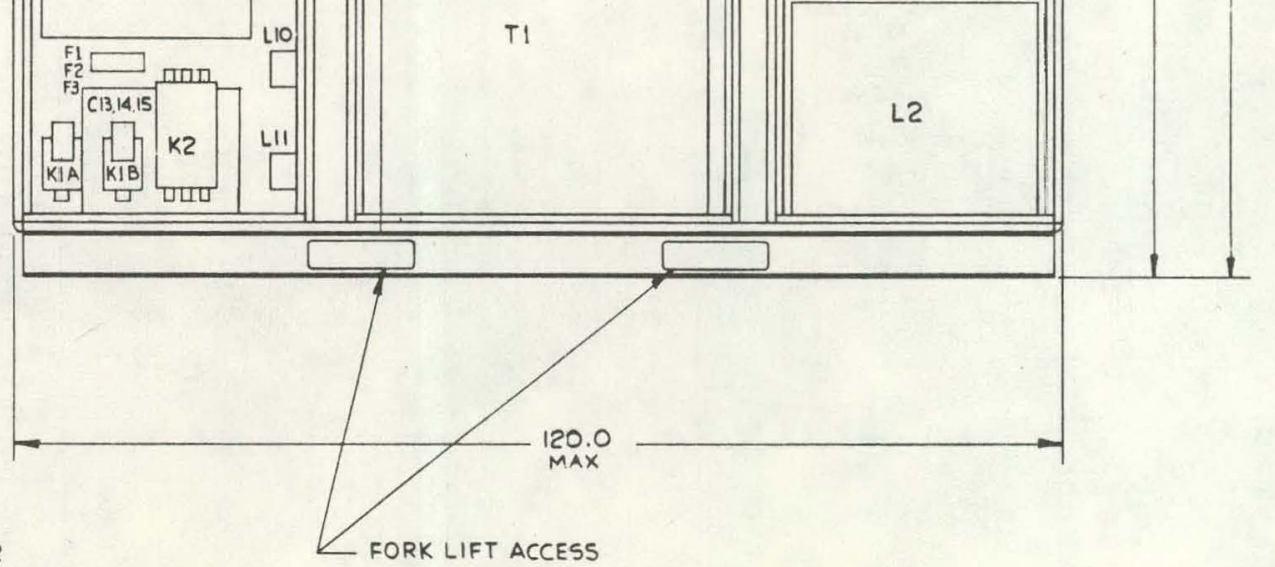


CONTRACT STATUS SUMMARIES 


\author{
DESIGN MODIFICATION \\ ANE \\ PRODUCTION ENGINEERING \\ FOR THE \\ ABACUS SUNVERTER
}

\author{
Aharus Controls Tnr. \\ Somerville, New Jersey 08876 \\ Principal Investigator: George A. O'Sullivan \\ (201) 526-6010 \\ Contract No.: $68-1406$ \\ Contract Amount: $\quad \$ 129,228$ \\ Contract Duration: November 1981 to \\ January 1983
}

\title{
Project Description
}

The existing sunverter product line meets or exceeds the technical requirements established by Sandia National Laboratories for residential applications. This contract is intended to simplify the design where possible and to develop a low-cost, high quantity. production design from a custom built product family.

\section{Current Status}

Recently introduced low-cost Darlington power transistors have been selected to reduce both the complexity and the cost of the power stages. The complexity of switching circuits and relay circuits has been reduced with the introduction of more solid-state analog switch devices.

A 4KVA single bridge breadboard is under construction. Each of the simplification and cost reduction techniques will be introduced one at a time and evaluated.

\section{$\underline{\text { Plans }}$}

The primary objective of the project is to reduce the cost of the sunverter family. This will be accomplished by introducing circuit simplification, less costly components, and a simpler mechanical design for reductions in the materials cost. Labor costs will be reduced by replacing hard wiring with printed circuits, by redesigning the printed circuit cards for automated assembly and automatic test equipment, and by streamlining the mechanical design to allow for modular subassemblies and single plane design.

The equipment to be delivered under the contract includes two single bridge $4 \mathrm{KW}$ Sunverters and one dual bridge $8 \mathrm{KW}$ Sunverter for residential service in the utility intertie mode. Automatic wake-up, 
max power tracking, and automatic evening turn-off are included. Operation is at unity power factor; maximum harmonic current is $4 \%$; and efficiency is $90 \%$ to $92 \%$.

In addition, a $4 \mathrm{KW}$ Sunverter and a battery interface module are being delivered. for use in residential applications in which the photovoltaic energy will be stored in the battery for the hours of peak electrical use. 


\author{
DESIGN AND CONSTRUCTION \\ OF 3 . \\ 75KW PHOTOVOLTAIC ARRAY SIMULATOR
}

\author{
Abacus Controls Inc. \\ Somerville, New Jersey 08876 \\ Principal Investigator: Steve Krsna \\ (201) 526-6010 \\ Contract No.: $46-0150$ \\ Contract Amount: $\$ 98,788$ \\ Contract Duration: January 1980 to \\ January 1982
}

Project Description

The contract requires the design, construction, and testing of a $75 \mathrm{KW}$ photovoltaic array simulator. The simulator must duplicate the I-V characteristics of photovoltaic arrays, and it must be operable in both a manual control mode and an automatic control mode.

1

\title{
Current Status
}

The $75 \mathrm{KW}$ photovoltaic array simulator has been designed, built, and tested to the Sandia specifications. The simulator is now in final clean-up prior to final testing and delivery.

\section{Key Results}

The test results on the simulator demonstrate that a wide range of I-V curves can be generated between near zero and $75 \mathrm{KW}$ to duplicate the characteristics of photovoltaic arrays. Open circuit voltage can be adjusted from 5OVDC to 400VDC. Short circuit current can be adjusted from almost zero to 250A. The fill factor is adjustable both manually and remotely between .48 and .76 .

The simulator was, tested with one of the Abacus Model 763-4-200 Sunverters rated at $6 \mathrm{KW}$. The sunverter max power tracker demonstrated the same stabilitity of operation as it. has in the southwest and Northeast Residential Projects.

In the manual mode of operation, the simulator is controlled with four precision 10-turn potentiometers that adjust open circuit voltage; short circuit current, which is proportional to insolation; the current slope, which sets the distance between the short circuit current and the max power current; and the voltage slope, which sets the distance between the open circuit voltage and the max power voltage. 
In the automatic mode of operation, the short circuit current adjust is replaced by a 0-5VDC signal. The open circuit voltage adjust, current slope adjust, and voltage slope adjust are replaced with binary resistor networks that are computer controlled with serial TTL compatible signals. 
DESIGN AND CONSTRUCTION OF A CONCENTRATING PHOTOVOLTAIC

TOTAL ENERGY SYSTEM IN HAWAII

\author{
by \\ Acurex Corporation \\ 485 Clyde Avenue \\ Mountain View, California 94042
Principal Investigator: Bob Spencer
(415) 964-3200 ext. 3532
Project Manager: Dariush Rafinejad
(415) $964-3200 \mathrm{cxt} .3531$
Contract Number: DE-AC04-79ET20623
Contract Amount: $\$ 2,234,677$
Contract Duration: 2 years construction, 2 years operation

Design and construction of Hawaij's largest solar energy system are described.. The project was sponsored by the U.S. Department of Energy (DOE) and the State of Hawai $i$ and was designed and constructed by Acurex Corporation. Wilcox Hospital is located on the island of Kauai and, like many other energy users in Hawaii, is totally dependent on expensive imported oil. The system generates $35 \mathrm{~kW}$ of $\mathrm{DC}$ power at $1,000 \mathrm{~W} / \mathrm{m}^{2}$ insolation. The major subsystems are the collector field, thermal energy subsystem, and electrical power generation. The photovoltaic (PV) collector field consists of $4,800 \mathrm{ft}^{2}$ of parabolic linear focus concentrators. The linear receiver is populated with PV cells and is actively cooled. The project construction is complete and the system is currently being commissioned. 
PHOTOVOLTAIC OFF-FARM AGRICULTURAL APPLICATIONS

Advanced Technology, Inc. McLean, Virginia 22102

Principal Investigator:

William F. Adolfson

Contract Number:

Contract Amount:

Contract Duration:

(703) $442-4647$

62-6590

$\$ 241,858$

October 1980 - December 1981

Project Description: The project objective was to assess the feasibility of near-term photovoltaic technology in the off-farm agricultural industry, which includes food processing, agricultural chemicals, tobacco, and alcohol fuels industries. Task objectives were to:

- Characterize appropriate off-farm agricultural applications having potential for conversion to photovoltaics.

- Describe the design of photovoltaic systems having significant potential to cut energy requirements economically.

- Estimate the value of photovoltaics in terms of life-cycle costs in contributing to energy supply in this sector.

- Recommend research and development activities having the greatest potential for near-term technical and economic viability in this sector.

Key Results: The off-farm agricultural industry uses the largest share of energy in the United States food industry to keep in operation the business of processing threefourths of the $\$ 290$ billion of food products before being shipped to market. Processing and agricultural chemicals industries use direct heat, process steam, feedstocks, and electricity to help improve food quality and palatability, extend edible shelf life, increase convenience, create new ingredients and foods, and produce high yields. Today, energy averages 9 percent of the consumer food dollar, and is as high as 17 percent in some industries.

Photovoltaics in appropriate off-farm agricultural applications can cut energy costs by supplementing conventional energy sources and producing energy at reduced cost per energy unit on a life-cycle cost basis.

- There is a large, technically feasible market potential for photovoltaics in the off-farm agricultural industry--about 0.3 quadrillion Btu's per year.

- High potential applications for near-term utilization will be for mechanical power and refrigeration in industries such as fertilizer manufacturing, meat packing, frozen fruits and vegetables, and ice cream industries; and electric and hot water use in the coffee industry. Areas in the West, Southwest, Northeast and Central regions are attractive for early adoption. 
- Of the technologies available in 1986, concentrating photovoltaic/thermal designs are most economic in areas having high direct insolation; although simple flat plate systems are generally cost-effective throughout the United States, under baseline financial conditions. Breakeven energy costs range from 2 to 5.5 cents per kilowatt hour compared to utility-generated electricity.

- The economic advantage of photovoltaics compared to conventional energy sources is significantly improved if lowered first costs, tax incentives, and smaller downpayments are present.

- Systems that are sized to deliver all their, output to the processing plant are more attractive.

Some markets are attractive, but early market penetration is impeded by major barriers:

- High degree of risk due to lack of experience in a production environment

- Lack of economic advantage and uncertain long-term benefits to investors under present conditions due to high costs of photovoltiacs and low cost of energy as a percent of sales

- Lack of discretionary capital

- Uncertain Government energy pricing and tax policies.

- A Federal program in technology research and development and incentive could be a principal factor in mitigating those constraints. 
PHOENIX SKY HARBOR AIRPORT

PHOTOVOLTAIC CONCENTRATOR PROJECT

\author{
BY \\ Arizona Public Service Company \\ Phoen i.x, Arizona 85036
}

Project Manager:

W. Joseph McGuirk

(602) $271-2431$

Contract No:

DE-ACO4-80ET20624

Contract Amount:

$\$ 6,501,000$

Contract Duration:

March 1980 to Jure 1982

Project Description: This project supports 'DOE'S PRDA-35 program with a Fresnel, point-focus design. Its purpose is to assemble, install, and check-out at the Phoenix Sky Harbor a photovoltaic system consisting of an 80 array subsystem with a nominal rating of 225 peak $\mathrm{kW}$. Two axis tracking, pedestal mounted arrays, each containing 272 lens-cell combinations and similar to those delivered to the SOLERAS $350 \mathrm{~kW}$ project, feed power to an inverter which in turn supplies the APS grid.

Current Status: All major components have been delivered to the site, and most have been installed. Array foundations are in place, the field wiring has been installed and checked out, and the facilities building is complete. The inverter has passed its factory acceptance test. Remaining critical activities prior to start of the 30-day system performance run include completion of assembly and check-out of individual arrays, installation and check-out of the inverter, and integration of the system control and display panel with the array field, inverter, and on-site data acquisition system. The 30-day run is targeted to begin March 15, 1982 .

Key Results: The project has provided a critical evaluation of alternative concentrator designs which incorporate the point focus Fresnel lens. The conclusion reached is that the smaller area lens-cell combination (module) when mounted onto a single pedestal tracker appears to offer greater potential to meet DOE's cost goals than does a larger module mounted onto a turntable tracker.

The array performance is expected to be improved by as much as $15 \%$ versus the Saudi arrays by the substitution of thermal grease for RTV at the interface between the cell/substrate and the heat sink. 


\title{
STUDY OF PHOTOVOLTAIC INTERMEDIATE SECTOR RETROFITS
}

\author{
by \\ Battelle-Columbus Laboratories \\ 505 King Averue \\ Columbus, Ohio 43201
}

\author{
Contract No.: $\quad 62-1259$ \\ Program Manager: 'Gerald T. Noel, (614) 424-7481 \\ Contract Amount: $\$ 209,578$ \\ Contract Duration: August 12, 1980 to December 31, 1981
}

OBJECTIVE - The overall objective of this program was to assess the technical and cconomic feasibility of retrofitting a significant portion of the new (1980) and existing (pre-1980) intermediate sector building/application inventory with photovoltaic (PV) systems. Specific tasks included:

(1) Assess inventory, characterize buildings/applications, and determine allowable life-cycle costs

(2) Select typical viable applications/buildings and adapt. or develop appropriate PV systems designs

(3) Identify detailed retrofitting techniques and hardware, develop and cost retrofit designs, and develop market assessment and cost scenarios

(4) Assess tcchnique and hardware development needs for retrofitting of buildings.

The scope of the study included flat-panel and concentrator photovoltaic systems and electrical and combined electrical-thermal loads.

STATUS - All task activities have been cumpleted, and a draft final report has been prepared for review. Inventories of buildings and building characteristics related to PV systems have been compiled for commercial, industrial, and institutional applications. Potential applications have been ranked, and representative promising applications were identified. Eleven retrofit system designs were developed, which address specific rcpresentative retrofit situations and application load characteristics as identified in the initial tasks of the study. Architectural and engineering drawings for these designs have been compiled into a drawing package which accompanies the final report. Cartoon-type drawings illustrating retrofit array-field installation concepts have been included in the drawing package. Detailed cost estimates were developed for eacli system, and provided the basis for regional life-cycle-energy cost analyses. Intermediate-sector retrofit market assessments were made for ground-mounted and for roof-mounted installations. The national intermediate-sector retrofit market was estimated to be of the order of 200 to 400 gigawatts.

The major barriers to a substantial retrofit PV system market are initial costs of major components and potential institutional factors. Recommended actions to accelerate penetration of the retrofit market include:

- Wide-spread dissemination of information on market/application attributes and appropriate systems designs to potential users and to system/component suppliers 
- Legislation which provides a favorable economic and institutional climate for retrofit PV installations

- Standardization and modularization of retrofit PV system component designs and standardization of installation techniques for maximum cost effectiveness

- Development of a local maintenance and repair force which provides small- to mediumsize users with confidence that system maintenance and repair requirements can be met in a timely fashion and at reasonable cost

- Continued documentation and publicizing of reliability and performance experience with existing PV installations to establish the credibility of the technology in the minds of a wide range of potential users.

The final version of the report will be issued upon Sandia approval. 


\title{
PHOTOVOLTAIC FLAT-PANEL ARRAY FIELD OPTIMIZATION AND MODULARITY STUDY
}

\author{
Contract No.: $\quad 62-9182$ \\ Program Manager: Donald C. Carmichael, (614) 424-6582 \\ Contract Amount: $\$ 498,084$ \\ Contract Duration: January 1981 to January 1982
}

Experience with the application experiments and other photovoltaic field installations to date has demonstrated that array-field balance-of-system (BOS) and engineering costs must be substantially reduced before photovoltaic power systems can be cost effective for grid-connected applications. Based on actual cost data for a representative application experiment (a 100-kW-peak flat-panel, ground-mounted installation), the array-field BOS costs were $\sim \$ 400 / \mathrm{m}^{2}$ and engineering costs were $\sim \$ 550 / \mathrm{m}^{2}$ of collector area. These costs are far too expensive for widespread commercial interest, regardless of the cost of photovoltaic modules. 'Ihis study was conducted by Battelle and its subcontractors to develop an optimized, modular array-field design to reduce significantly these costs for ground-mounted flat-panel photovoltaic array fields.

The specific objectives of the study were (1) to develop innovative and integrated designs for the structural and electrical array-field subsystems and (2) to incorporate these designs in a standardized, modular building block which can be used to construct various sizes of photovoltaic array fields at minimum lifecycle energy cost. The subsystem areas investigated included the support structure, foundation, site preparation, field wiring, module wiring, grounding, lightning protection, and EMI-suppression considerations.

The modular array-field design developed is applicable for near-term (1982-1983) implementation and reduces the array-field balance-of-system initial costs to a fraction of those previously experienced. The design also incorporates improved reliability relative to comparable existing installations and minimizes maintenance requirements and costs. No major capital investment in plant or equipment is required to implement the design. A detailed Project Manual and Construction Specifications and a complete engineering Drawing Package have been prepared for the developed building block design.

For the array-field design, a field operating voltage of 400 VDC was specified. The Nominal Operating Conditions (NOC) specified for rating purposes were $80 \mathrm{~mW} / \mathrm{cm}^{2}$ and $A M 1.5$ with the cell at Nominal Operating Cell Temperature. The goal that the design should have immediate impact on reducing the costs of array field installations dictated that the design must use presently available or readily developed components and that it must not require an automated factory or equipment involving large capital investment and long lead time. A module size of $2 \times 4 \mathrm{ft}$ was used as the basis for the design, since this is the largest size readily available at present; however, the design is applicable to other sizes. Key characteristics of the developed design are:

- PV Module - 5 VDC Output; Minimum of 5 Parallel-Connected Cell Strings; Integral Diodes

- Foundation - Steel Hat-Section Stakes and $4 \times 4$ in. Wolmanized Wood Beams

- Structure - Lightweight Steel Angle and Tubing; Two-Modulc Pancl $(4 \times 4 \mathrm{ft})$

- Branch Circuit - Peak Output $10 \mathrm{~kW}$ at NOC with 10\% Efficient Module; 400 VDC; Two Modules in Parallel, 82 Pairs in Series

- Intermodule Wiring - Crimp-Spliced Pigtails with Insulating Pad

- Field Wiring - Direct Burial Feeder Cables 
- Building Block Size - Approximately $10 \mathrm{~kW}$ Peak (One Branch Circuit); Two Rows of Structure; Area $\sim 165 \mathrm{ft}$ (East-West) by $18 \mathrm{ft}$ (North-South) Including Aisleways

- Cost - Array-Field BOS Installed Price of $\sim \$ 52 / \mathrm{m}^{2}$ (1980 dollars).

Included in array-field BOS costs are site preparation and fence, all structure and foundation components and installation, and all electrical materials and labor for field wiring, grounding, and lightning protection. Power conditioning equipment and modules are not included. The cost estimate is based on a production quantity of $1 \mathrm{MW} / \mathrm{yr}$ and contractor and supplier quotations in 1981 dollars, converted to 1980 dollars using a factor of 0.92 .

The structure/foundation design has the following features: fabricated at minimum cost using simple and available components; accommodates sites with some uneveness of terrain with little site preparation requirements; adapts eàsily to various latitudes and site conditions; easily grounded; built entirely of components that can be handled by one person; easily accessible for cleaning; lends itself to simple automation of assembly with minimum capital investment. Key characteristics of the electrical design are: high degree of cell series-parallel interconnection; high bypass diode density; simple low-cost module interconnection; and lightning protection against induced current surges but not direct-strike interception. The major advantages of the electrical design are that it: minimizes the impact of cell failures on the power output, thus permitting low maintenance and. low life-cycle energy cost; has low module interconnection and wiring costs; uses structural components to simplify module and structure grounding; has minimum lightningprotection costs; and has in-field provision for isolation and testing of individual branch circuits. 


\title{
PHOTOVOLTAIC CONCENTRATOR ARRAY FIELD OPTIMIZATION AND MODULARITY STUDY
}

by

\author{
Battelle-Columbus Laboratories \\ 505 King Avenue \\ Columbus, Ohio 43201
}

\section{Contract No.: $\quad 68-1517$}

Program Manager: Donald C. Carmichael, (614) 424-6582

Contract Amount: $\$ 196,876$

Contract Duration: August 5, 1981 to March 31, 1982

The ovcrall objective of this study is to develop modularized photovoltaic (PV) concentrator array-field building block designs which minimize the field installation and wiring costs for two concentrator collector designs specified by Sandia. The building block designs will be suitable for use in multiples to construct lowcost medium-size and large-size array fields. Array field layouts for medium-size fields of 20-, 100-, and 500-kW peak are to be prepared using the developed building blocks.

This study is directed to the incorporation of existing PV concentrator collectors into minimum cost array-field systems, rather than to the development of new PV concentrator module or array designs. Two specific concentrator designs have been selected for this study based on their long-range potential for low cost: (1) a point-focus Fresnel-lens concéntrator array using a center-post mount and (2) a line-focus Fresnel-lens concentrator module mounted in a center and end-supported frame. Both systems are passively cooled and use two-axis tracking.

Specific objectives of the study are:

- To develop a modularized building block size/design which is applicable for use in installing array fields of nominally $20-k W$ peak and larger, for each of two existing and specified PV coricentrator collectors

- To design nominal 20-, 100-, and 500-kW array field layouts using the developed building blocks for the two specified PV sonnsentratnrs

- To develop and deliver working drawings, specifications, and cost estimates for each of the modularized array-field designs including site layout and requirements, field wiring, and controls, utilizing the specified collectors.

Recommended building block sizes have been established for both the E-Systems (line-focus Fresnellens concentrator) and the Martin-Marietta (point-focus Fresnel-lens concentrator) second-generation array designs. The building block sizes are based on considerations of desired array field operating voltage, compatibility with specified array field sizes, array performance characteristics, and other factors. The recommended building block configurations and their characteristics are:

\section{E-Systems}

- Number of Modules - 28

- Number of Arrays (4 modules/array) - 7

- Configuration - 2 parallel strings of 14 series-connected modules per string 
- Power Output at NOC $-8.1 \mathrm{~kW}$

- Nominal Operating Voltage (NOV) - 420 VDC

- Current at NOV - $19.3 \mathrm{~A}$

- Bypass Diodes - 1 for every group of 9 series-connected cells

Martin-Marietta

- Number of Modules - 180

- Number of Arrays (60 modules/array) - 3

- Configuration - 3 parallel-connected arrays

- Power Output at NOC - $11.1 \mathrm{~kW}$

- Nominal Operating Voltage -420 VDC

- Current at NOV - 26.4 A

- Bypass Diodes -1 for every group of 14 series-connected cells.

Alternative array wiring configurations were analyzed but were found either to yield insignificant life cycle cost advantages or to be incompatible with array field constraints. The recommended configurations are compatible with lifetime, performance, and maintenance objectives.

Shading analyses using computerized models are being performed to define appropriate inter-array spacings for the two array designs. Recommendations of spacings for a baseline case of $35^{\circ}$ north latitude (Albuquerque) and for a range of other latitudes representative of the continental United States are being developed with the assistance of E-Systems and Martin-Marietta. Present baseline case concepts include an inter-row spacing of approximately $13 \mathrm{ft}$ for the E-Systems design and a closest center-to-center pedestal spacing of approximately $58 \mathrm{ft}$ for the Martin-Marietta design.

Both of the array designs being considered use post-type foundations. Data on the structural designs, their capabilities (i.e., withstanding forces), and appropriate site conditions and requirements have becn collected. These will be tabulated for use in assessing specific site situations.

Control system requirements which are compatible with the modularized building block concept have been determined. In-depth analyses of E-Systems' and Martin-Marietta's control schemes have been performed to assess their adaptability to the modularized approach. The Martin-Marietta system appears to be directly applicable in this respect. The E-systems control system requires modification to provide the most economical configuration for implementing large array fields. Data on several alternative array field control systems have been collected and are being evaluated.

Designs for 20-, 100-, and 500-kW array field sizes are being developed for each of the two concentrator module/array designs using the modular building blocks as a basis. Sets of spccifications and detailed site and electrical drawings (including control and power wiring drawings) will be prepared for each design. Cost estimates, using the manufacturers' cost projections for the module/array itself, will be developed for the modular array field installations. 


\title{
DEVELOPMENT OF A PHOTOVOLTAIC SYSTEMS \\ RELIABILITY ANALYSIS METHODOLOGY AND \\ RELIABILITY-ECONOMICS ASSESSMENT
}

by

\author{
Battelle-Columbus Laboratories \\ 505 King Avenue \\ Columbus, Ohio 43201
}

\author{
Contract No.: $\quad 62-8278$ \\ Project Manager:: Larry Stember (614) 424-5810 \\ Contract Amount: $\$ 216,619$ \\ Contract Duration: December 18, 1980-February 17, 1982
}

OBJECTIVE - This program has the objective of developing and demonstrating a methodology to model PV system reliability and to integrate the parameters of reliability and maintenance costs into the life-cycle energy cost model. The results of this program will aid systems design and development by influencing decisions on alternative subsystems or design configurations toward those whose reliability/maintainability parameters will lower the system's life-cycle energy costs. Specific tasks in the study are:

(1) Categorize PV systems/subsystems design and failure modes; (2) determine and exercise the best methodology for reliability analysis; (3) apply the methodology to three PRDA Phase II designs; (4) develop a maintenance cost model; (5) interface the reliability model and the maintenance cost model with the system life-cycle energy cost model to include these factors in system design decisions.

STATUS - The first four tasks of the study have been completed and a comprehensive interim report has been provided to Sandia. Effort is now being directed to completing the integration of the availability (reliability and maintainability) methodology with the life-cycle energy cost model.

Two approaches, a state space model and a simulation model, were used to represent the system availability of three PRDA Phase II system designs. The PV systems modeled were: the Lea County Electric Flat-Panel PV System, the Arizona Public Service Concentrator PV System, and the BDM Actively Cooled Concentrator PV System. All were modeled using actual system functional design and estimated reliability and maintenance cost data in advance of the availability of actual field data. A typical output from the simulation model is shown in Figure 1. This presents the estimated present value of annual maintenance cost for a $565 \mathrm{kWp}$ generic, passively cooled concentrator system over a 30-year period. This form of output is convenient as input to the life-cycle energy cost model. Additional cost inputs to this model will, uf cuurse, be required. Other useful outputs are produced such as: listings of annual failures per subsystem/component, cumulative energy produced annually, and system availability.

Life-cycle energy cost (LEC) may be estimated by combining the maintenance cost outputs from the availability model with other costs. These include initial capital costs, operating costs, and assumed financial parameters such as discount rate, etc. The levelized value of LEC may then be used as an objective function in system optimization studies to guide decisions regarding adjustments to system design, reliability, maintenance strategy, and other design alternatives. 


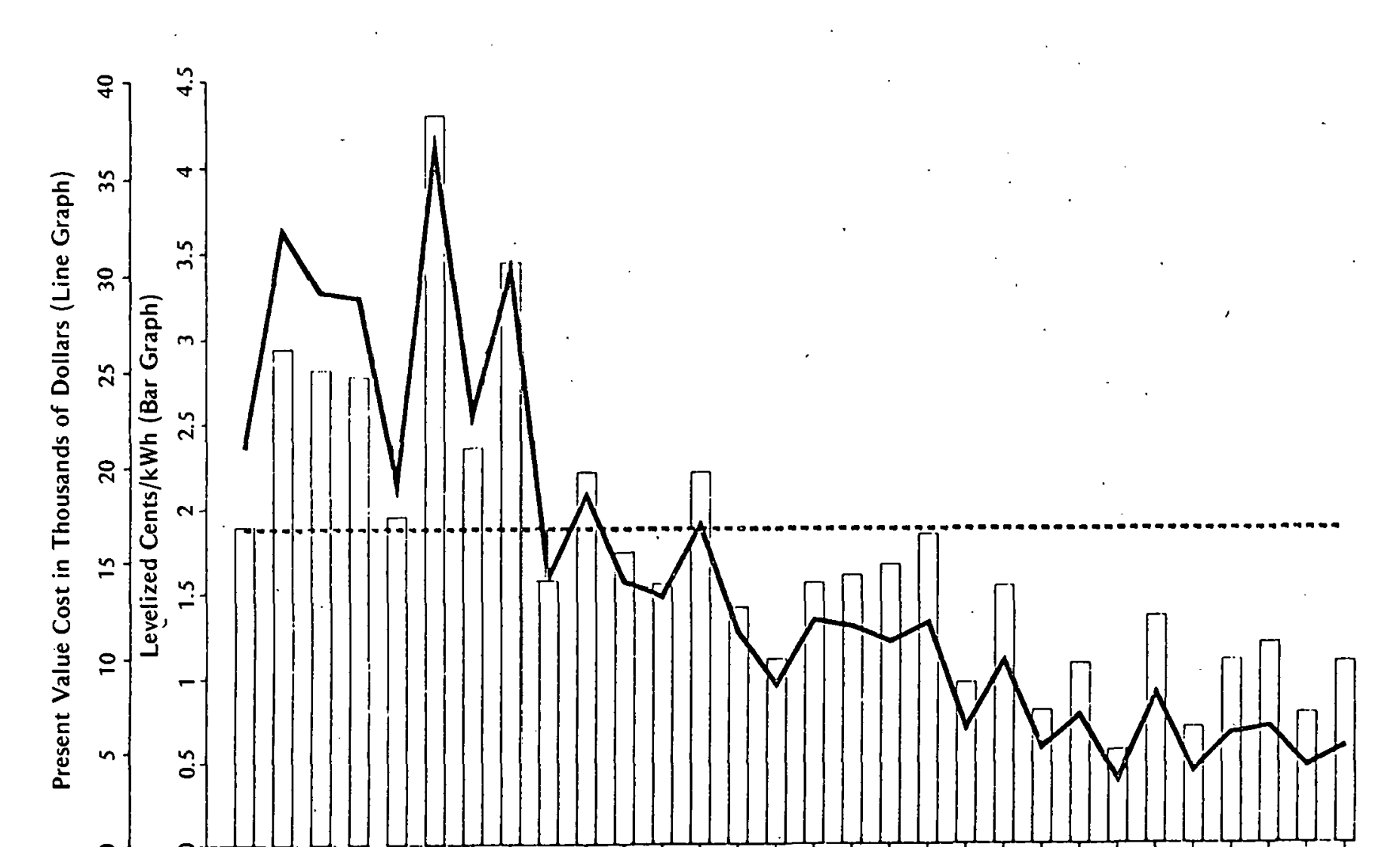




\author{
DETAILED RESIDENTIAL ELECTRIC LOAD \\ DETERMINATION \\ by \\ The BDM Corporation \\ Albuquerque, NM 87106 \\ $\begin{aligned} \text { Principal Investigator: } & \text { George J. Collaros } \\ \text { Contract No.: } & 62-39778-5320 \\ \text { Contract Amount: } & \$ 255,000 \\ \text { Contract Duration: } & \text { October } 1980 \text { to } \\ & \text { February } 1982\end{aligned}$
}

ABSTRACT

The BDM Corporation (BDM) is conducting a direct measurement program of residential electric loads to develop a statistical model of residential electric load patterns which describes "instantaneous" load behavior from time-averaged data. The objective of the program is to determine the effect of transient loads on the net annual output of residential photovoltaic (PV) systems and to obtain residential load data at sample periods lower than 15 minutes to support different PV test programs. The work is being performed by BDM under contract with Sandia National Laboratories.

The Residential Load Project is divided into five phases directed at defining and acquiring instantaneous load data from residences and utilities and then using these data in PV system performance models. A comprehensive survey of utilities and related sources has shown that there is a lack of representative load data collected in intervals of less than 15 minutes. A direct measurement program has been initiated for three regions of the United States that will provide high resolution residential load data at intervals of 5 seconds. Powerline waveform quality measurements were taken on two residences and on a selection of inverters to determine the current and voltage waveform in both the time domain and frequency domain. A preliminary statistica model has been developed which can use time-averaged data typically collected by utilities to generate a set of higher frequency and amplitude instantaneous-like electrical load transients.

\title{
1. DIRECT MEASUREMENT
}

For the direct measurement portion of the program, typical residences in the northeast, southeast, and southwest regions of the country were sampled in cooperation with utility companies preseritiy monitoring data at 15-minute intervals. For the instantaneous data required, BDM has selected a hardware package capable of measuring loads at intervals of approximately 5 seconds.

A comprehensive survey was completed of the two largest utilities in each state of the regions concerned. A total of 51 utilities were contacted to determine the extent of residential load monitoring programs, sample size, and sampling interval. The utility survey revealed that the majority of utilities have instituted residential load monitoring programs but at time-averaged intervals of 15 to 30 minutes. No sources of "instantaneous" load data were identified from utilities, utility organizations, or government research projects. 
A direct measurement program was then initiated to develop a sample of "instantaneous" residential electric loads on typical residences in the northeast, southeast, and southwest regions of the country. The Public Service Company of New Mexico, Georgia Power and Light, and the Public Service Electric and Gas Company of Newark, New Jersey were selected for participation in the program. Residences were selected by the utility from their current residential monitoring program on the basis of electrical consumption which approximates the sample mean from utility data base. Four residences were instrumented, two in Albuquerque and one each in Atlanta and Newark.

For the "instantaneous" load data collection, BDM has selected a hardware package capable of measuring loads at intervals of approximately 5 seconds. The data acquisition hardware consists of two major sections, (1) the measurement equipment, and (2) the computer controller. Measurement equipment is located at each of the four houses being monitored. A weatherproof box built to NEMA specifications houses a complete measurement system. Two-ten ampere toroidal current 10op transformers are connected to a Scientific Columbus JEM (Joule Electronic Meter) where data is measured in units of KVAH. After digitization within the JEM, the accumulated data is collected at regular intervals by the computer/controller via telephone lines. Both the JEM and the computer/controller are connected to the phone lines via Tek-com 300 baud modems. The computer/controller is an HP-85 desktop computer chosen for both its data collection and analysis capabilities. Data accumulated in the HP-85 is stored on five inch floppy disks. Twenty-four hours of data collected every five seconds will easily fit on one disk.

Data collection software was written in HP-85 Basic and includes data acquisition, analysis, and transfer programs. The data acquisition, program queries the JEM meter every five seconds, then reads and processes the returned data. Every minute, the accumulated data are sent to the floppy disk for permanent storage. An analysis program plots the data on the HP-85's CRT and a hardcopy may be obtained from a built in thermal plotter. In addition, a data transfer program transfers the data to the SNLA computer network where statistical packages such as BMDP may be used for further analysis.

Continuous data was collected on site for ten days each in July, 1981 at the Atlanta and Newark homes. Each of the two Albuquerque homes was continuously monitored for two weeks in September 1981. The summer data base consists of 48 days of continupus data collected at 5 second intervals, or approximately 830,000 data points. A winter data base of one week of data per house is currently being collected. All data collected has been reformatted into an easy-to-analyze form amenable to distribution to interested parties.

Powerline waveform quality measurements were conducted using a Spectral Dynamics FFT computing spectrum analyzer and high frequency current probes. A special buffer amplifier was constructed to compensate for the frequency response of the current transformers and correct for gain and phase variations with frequency for the time domain data. Data was collected in both the time and frequency domain. Sufficient data was taken to determine the waveform produced by various appliances, waveforms generated during normal household activities and to examine switching transients.

\section{LOAD MODEL}

Since utilities have a large amount of residential electric load data at 15 minute intervals, the fundamental objective of the statistical model is to predict instantaneous profiles as a function of at least the 15 minute average. Other factors; such as geographical region, season, and house characteristics; will be incorporated if found to be significant from the data sample. Originally, the model was planned to take the form of a multiple linear regression prediction equation. However, analysis has shown that the instantaneous profiles are driven by particular appliances. Since a large sample of instantaneous appliance loads would be required to 
adequately model their input to the load profile (much larger than feasible for this project), an alternative modeling methodology was developed.

Each 15 minute interval wili be characterized by periodic regression analysis (sums of sine and cosine curves). The coefficients of these regression equations characterize the 15 minute profiles and will be used to classify and distinguish between the significantly different profiles. Prediction of the different profiles will be accomplished by probabilities based on frequency of occurrence, or by discriminant analysis combined with a time series approach if enough explanatory information exists in the somewhat inadequate data base.

The statistical model will be structured into an algorithm which will predict the type of instantaneous profile to use based on the 15 minute time-average load. This alogorithm will be incorporated in to the SOLCEL photovoltaics analysis computer code, which uses a full year of weather and 15 minute load data and performs economic and performance analyses. The model will be exercised to determine the effect of instantaneous loads versus time-average loads on the economic and performance outcomes. 


\section{ANALYSIS OF CONCENTRATING PV/T SYSTEMS FOR THE}

COMMERCIAL/INDUSTRIAL SECTOR

\section{by}

The BOM Corporation

1801 Randolph Rd., S.E.

Albuquerque, New Mexico 87106

Principal Investigator:

William E. Schwinkendorf (505) 848-5318

Contract Number:

Contract Amount:

Contract Duration:

Project Description: The purpose of this program is to develop feasibility assessments, design procedures, and reference designs for total photovoltaic/thermal (PV/T) ener.gy systems that utilize actively cooled concentrating photovoltaic collectors. The design procedures will be for comiercial and industrial applications with thermal and electrical loads that can be partly or totally displaced by the PV/T system in a potentially more cost-effective manner than a strictly photovoltaic and/or solar thermal system. The program has been divided into four tasks:

Task 1: Review previous systems studies and designs to identify the current state-ofthe-art PV/T technology. Select and rank a preliminary set of 10 industrial and conmercial application/site pairs.

Task 2: Based on the review and analysis of Task 1, the major technical and design issues associated with PV/T technology will be identified. Appropriate design guidance will be developed to economically resolve these issues or lessen their impact.

Task 3: A detailed reference design will be developed for an optimally sized concentrating PV/T system for three applications: one commercial, one industrial, and a third from either sector.

Task 4: Perform design trade-offs on the detailed designs developed in Task 3.

Current Status: Documents pertaining to the analysis and ranking of solar thermai, solar total energy, photovoltaic, and $P V / T$ systems for application to the commercial and industrial sectors have been obtained and are being reviewed. Load profile data in the open literature for the industrial sector has been found lacking; however, a data base for the industriai sector has been developed and is available from General Energy Associates (GEA). Design and operational data for existing corcentrating $P V / T$ systems is being reviewed in order to characterize. the state of the art. 
INTEGRATED STRUCTURE DESIGNS FOR PHOTOVOLTAIC ARRAYS

by

H. A. FRANKL IN

Bechtel Group, Inc.

50 Beale Street

San Francisco, California 94105

\author{
Principal Investigator: H. A. Franklin \\ (415) $-768-8778$ \\ Contract No.: 62-9877 \\ Contract Amount: $\$ 428,436$ \\ Contract Duration: January 1981 - March 1982
}

Project Description: The major purpose of this work is to develop low-cost, integrated design concepts for flat panel support structures and then to fabricate and install a small, dummy prototype array field as a proof-of-concept demonstration.

Current Status: Work began by reviewing available array support concepts and proposing new ones for further cost reductions. Two candidate support concepts were selected which showed the most promise of achieving low cost. Structural design criteria was developed which included an effort to reduce conservatisms which were excessive for these applications. Wind design criteria was based on a series of wind-tunnel tests directed by Bechtel at the Colorado State University test facility. Dynamic effects due to fluctuating winds were estimated. Span lengths of the support structures were varied to achieve optimized designs.

Final array designs were optimized and construction work is being planned for the installation of a small, non-working array field using the selected designs. This installation is planned for Albuquerque in early 1982. The final report for this study is being drafted.

Key Results: Wind forces on the interior of a large array field can be $63 \%$ Tower than those forces on the perimeter arrays. Even though the use of fences reduces wind loadings on the perimeter arrays, cost estimates showed the ir use were not cost effective.

Final array designs consisted of a $8^{\prime} \times 36^{\prime}$ steel panel frame supported at both ends by either wood pole or concrete caisson foundations. Installed direct costs in mid - 1981 dollars based on a $10 \mathrm{MW}$ array field size were $\$ 34.80 / \mathrm{m}^{2}$ for the wood pole design and $\$ 34.00 / \mathrm{m}^{2}$ for the concrete caisson design. 


\author{
THE DATA REDUCTION CENTER \\ FOR \\ PHOTOVOLTAIC APPLICATIONS EXPERIMENTS
}

\author{
Boeing Computer Services \\ Tukwila, WA 98188
Principal Manager: Joseph T. Muldoon
(206) $575-5155$
Contract No.: 13-8019
Contract Amount: $\$ 1,551,712$
Contract Duration: 1 February 1980 to
1 February 1982

Project Description: The prime function of this project is to collect, archive, and provide summary analyses from the intermediate photovoltaic System Application Experiments. The Center acquires, interprets, stores and provides data reports on the site performances for use by the contractors, governmental, academic and private concerns interested in the actual state-of-the-art efficiency and behavior of the various and diverse photovoltaic site configurations.

Current Status: The system is currently collecting data from five operating sites, with seven more sites due for inclusion in 1982. The center is successfully getting data from the on-site data acquisition instrumentation; processing it through a front-end minicomputer providing transmission protocol, verification and range-checking; analyzing and archiving raw and processed data; and producing and disseminating site performance reports. The original system is continuously being upgraded to improve efficiencies and to adapt for site-specific idiosyncrasies. The ongoing effort is collecting required noninstrumented data as well as coordinating computer interfaces for new sites as they become activated.

Key Results: Currently data are being collected from 5 sites with an average of 25 data elements collected per site at intervals as frequent as 10 minutes. A 25 page data report is prepared monthly for each site.

As individual sites have been added to the system, the data conter has and is detecting and correcting discrepancies between site configurations and requisite reportable performance measures by providing feedback to the sites. Further, it is providing a generically feasible center capable of addressing the data base needs of distinct photovoltaic systems and operational modes, with the capacity for responding to yet different types and sizes.

Data collection, reduction, and reporting has become largely standardized and routine for sites which have established steady state data collection. The timeliness and efficiency of these operations is constantiy improving and is providing the performance evaluating community with unbiased and accurate inf ormation. 


\author{
INVESTIGATION OF LOAD MANAGEMENT STRATEGIES \\ FOR RESIDENTIAL PHOTOVOLTAIC SYSTEMS \\ by \\ Department of Electrical and Computer Engineering \\ Clemson University, Clemson, SC 29631 \\ Principal Investigator: Jay W. Lathrop \\ (803) $656-3370$ \\ Contract No.: $62-9162$ \\ Contract Amount: 47,766 \\ Contract Duration: September 1980 to \\ December 1981
}

\begin{abstract}
Project Description: The purpose of this program is to develop a methodology for evaluating the effect of various load management strategies applicable to residential photovoltaic systems.

Current Status: A simulator has been developed and is running on the Clemson computer which simulates the electrical demand of an all-electric single family residence as well as the power output of a PV system with battery storage. Possible load management strategies irvolving the dryer operation, thermal storage (water and house), battery charging, and minimm inverter output have been incorporated. Economic analyses involving system life cycle cost will be performed on a sunbelt and a non sunbelt location.
\end{abstract}

Key Results: The residential demand model is based on the instantaneous use of energy rather than the hour-by-hour averages used in previous models. This results in a significant reduction in the direct use fraction, i.e. the fraction of the PV output which can be used directly by the residence, and makes the economics of PV more dependent than previously thought on storage availability, sell back ratios, and load management strategies. 


\author{
INVESTIGATION OF A FAMILY OF POWER CONDITIONERS \\ INTEGRATED INTO THE UTILITY GRID \\ THE GARRETT CORPORATION \\ TORRANCE, CA 90509 \\ Principal Investigator: Thomas $P$. Prouty \\ (213) $512-4091$ \\ Contract No.: DE-ACO2-80ET29311 \\ Cantract Amount: $\$ 179,560$ \\ Contract Duration: May 1980 to December 1981
}

Project Description: The purpose of this program is to investigate and characterize the electrical interfaces, particularly the utility interface; to design optimum power converters in both the residential class of 5 to $30 \mathrm{KW}$ as well as the load center class of 30 to $200 \mathrm{KW}$; to quantify and present the performance characteristics of both power converters; to present the results in a final report.

Current status: All work has been completed and the final report has been written, reviewed, and a final version submitted.

Key Results: The AC interfaces were studied by Public Service Electric and Gas of New Jersey and a detailed characterization has been developed for both single phase residential service and three phase industrial service. The interface voltage selected for residential service is 240 volts nominal. Since the optimum designs for this size inverter required a relatively large capacitive output filter, a survey was made to determine the maximum allowable capacitance across such a circuit. The required 60 microfarads was found to be permissible.

For residential applications, a rating of $8 \mathrm{~kW}$ was selected. The final design utilizes biploar transistors operating at a switching frequency of approximately $3 \mathrm{KHz}$ and using pulse width modulation to produce a low frequency fundamental output. Efficiency at rated load is $90 \%$. Weight is estimated to be 311 pounds and the size is $14 \mathrm{w} \times 11 \mathrm{~d} X$ $60 \mathrm{~h}$. Cooling is by natural convection. The computed MTBF per MIL-HDBK $217 \mathrm{C}$ Notice 1 at $55^{\circ} \mathrm{C}$. is 28,483 hours. Large quantity production prices are estimated to be $\$ 2000$ per unit (June 1981 dollars).

The load center rating was selected to be $200 \mathrm{KW}$. A unique arrangement of thyristors in a line commutated current fed inverter operating in parallel (at the $A C$ port) with a thyristor reactive power generator provides nearly perfect power factor, under $3 \%$ harmonic voltage distortion and a full load efficiency of $94 \%$. Weight is estimated to be 8433 pounds and the size is $1201 \times 33.5 \mathrm{~d} \times 107 \mathrm{~h}$ over the air ducts outlets. Cooling is 2 fans. The computed MTBF is 9870 hours. Large quantity production prices are estimated to be approximately $\$ 47,700$ per unit (June 1981 dollars). 


\title{
INITIAL DETAILED DESIGNS FOR INTERMEDIATE PV SYSTEMS
}

BY

GENERAL ELECTRIC COMPANY

ADVANCED ENERGY PROCRAMS DEPARTMENT

P. 0. BOX 527

KING OF PRUSSIA, PA 19406

\author{
Yrogram Manager: J. Herz \\ (215) $962-5826$ \\ Contract No: 74-0800 \\ Contract Amount: $\$ 340,953$ \\ Contract Duration: January 1981 - May 1982 .
}

Project Description: The primary objective of this study is to develop four PV system designs, beyond the conceptual level, for intermediate sector applications in the peak power range of 20-500 kW. These designs can then be used as reference designs for future applications. The work is organized into the following tasks: selection of the four application/site pairs, system descriptions, installation details and specifications, and design generalizations including performance and economic tradeoffs.

Current Status: All four designs have been completed and are being documented. The first report on a $6 \mathrm{~kW}$ direct mount system has been issued as SANDIA81-7178, and the second report on a $41 \mathrm{~kW}$ passive, point focus system is under review at Sandia. The remaining reports on a $128 \mathrm{~kW}$ flat plate system and $155 \mathrm{~kW}$ PV-Thermal system are underway and will be completed by the end of February 1982.

Additional work on a design of a structure that leans against the side of a building, and summary of design guidelines and lessons learned has been initiated.

Key Results: A design basis for many applications has been established with the four diverse designs presented. An economic assessment of these applications indicates that PV-Thermal applications are very attractive relative to $\mathrm{PV}$ only applications, $70 \mathrm{c} / \mathrm{Wp}$ module price goals are necessary for significant penetration of the intermediate sector, and that the life cycle cost of land for the private sector is very significant thus making roof-top applications desirable for many applirations. In general two and occasionally three of the following four key factors must be favorable for grid connected system viability:

1. System price of approximately $\$ 2.40 / \mathrm{Wp}$ corresponding to module price gnals of $\$ 0.70 / \mathrm{Wp}$ with current performance.

2. Combined investment plus solar tax credits totalling $25 \%$.

3. Electricity price escalation rate of at least $2 \%$ above inflation.

4. Peak period electricity pricing that more equitably passes utility generation costs to consumers. 
ANALYSIS OF SMALL COMAERCIAL PV APPLICATIONS

BY

GENERAL ELECTRIC CCITPANY

ADVANCED ENERGY PROGRAMS DEPAPTMENT

P. O. BOX 527

KING OF PRUSSIA, PA 19406

Program Manager: J. Herz

(215) $962-5826$

Contract No: $62-7317$ ।

Contract Amount: $\$ 347,925$

Contract Duration: October 1980 - January 1982

Project Description: The objective of this study is to determine the more promising applications for small commercial photovoltaic installations in the peak power range of 20-300 kW, for specific geographical regions. The work consists of two tasks: identification and initial evaluation of potential candidate applications, and detailed performance and economic analysis of select applications.

Current Status: All basic work has been completed and a draft final report is being reviewed by Sandia. A brief analysis of modular system design optimization is underway.

Key Results: The two dominating influences in the comparison of various applications vere geographic location and availability of a significant year-round, low temperature thermal load. Higher savings in PV-Thermal applications directly translate to better system economics which is the key factor in application ranking. Geographic location affects system savings potential in two ways: PV system output is a direct function of regional solar insolation levels, with system savings additionally relying on regional energy prices. Additional differences between applications include financial factors, load size and profile, and roof/ground space availability. The existing $25 \%$ total tax credit applicable to solar Installations brings system financing costs (fixed charges) for taxable applications down into the range of that for tax-free institutions. Banks and government office applications provide the most favorable economic factors, with supermarkets and non-profit hospitals the least favorable among the applications considered. The difference in PV system value, or equivalently allowable price is about $30 \%$ over the range of application-specific financial parameters assumed for the various applications.

Land carrying charges are substantially higher for the taxable applications due to several factors, including:

1. Land cannot be depreciated for tax purposes.

2. Property taxes, although assumed to be waived for the PV system, are applicable to the J.and it sits on.

3. Land appreciation is taxable.

The net result is to make ground mounted PV systems much less attractive in taxable applications as compared to government or tax-free institution applications.

Life cycie break-even module values for various applications/regions/economfc scenarlos are provided. From these it is evident that at least two and, more often threc of the rollowing four key factors must be favorable to achieve viability:

1. System price of approximately $\$ 2.40 / \mathrm{Wp}$ corresponding to module price goals of $\$ 0.70 \% \mathrm{Wp}$ with current performance.

2. Combined investment plus solar tax credits totalling $25 \%$.

3. Electricity price escalation rate of at least $2 \%$ above inflation.

4. Peak period electricity pricing that more equitably passes utility generation costs to consumer:s. 
DETAILED RESIDENTIAL PHOTOVOLTAIC PREFERRED DESIGNS

BY

\author{
General Electric Company \\ Advanced Energy Programs Department \\ P. 0. Box 527 \\ King of Prussia, PA 19406
}

\author{
Program Manager: E. M. Mehailck (215) 962-5842 \\ Contract No.: $13-8779$ \\ Contract Ainoune: $\$ 499,491$ \\ Contract Duration: August 1979 - December 1981
}

\begin{abstract}
Project Description: The objective of the Detailed Residential Photovoltaic System Preferred Design Program is to develop regionally appropriate detailed Photovolcaic system designs covering the major system options for the 1987 time frame in habitable residences. The designs are being prepared for four regions of the country, the Southwest, the Northeast; the Southeast and a temperate climate. The designs consider various hardware options for the major subsystems. The output from the program includes for each design a separate report with a complete system description including design requirements, functional characteristics and site characteristics; a block diagram; full scale electrical line drawing; thermal drawings; pictorial layouts; summary of performance characteristics and - tradeoffs; and subsystem and component specifications. The designs developed can be used as reference designs for typical equipment requirements, system performance estimates, installation details and system cost estimates.
\end{abstract}

Current Status: Six designs have been completed and reports written. These designs include:

1. An all PV system for a Southwest residence

2. A side-by-side PV/thermal system for a Northeast residence

3. A PV system with battery storage for the Southwest

4. An all PV system for a passive house design for the Northeast

5. An integral mounted array for a Southeast residence

6. A standoff and integral mounted array for a temperate climate.

A final progran report has also been completed.

Key Results: The all PV system with feedback to the utility remains the simplest system to Implement. Systems with battery storage present additional design concerns with respect to iocation of the batteries within the house. The designs provide detailed drawings for Installation of direct mounted modules (PV shingle and batten types), standoff mounted modules and integral mounted modules.

New construction house designs were developed for cach application. Floor areas ranged from $142 \mathrm{~m}^{2}$ to $161 \mathrm{~m}^{2}$ with south facing roof areas ranging from $44 \mathrm{~m}^{2}$ to $104 \mathrm{~m}^{2}$. The PV system slzes ranged from $4 \mathrm{~kW}$ to $8 \mathrm{~kW}$. 
PHOTOVOLTAIC ARRAY FIELD

OPTIMIZATION AND MODULARITY STUDY

HUGHES AIRCRAFT CO.

P.0. BOX 90515

LOS ANGELES, CA. 90009

\author{
PRINCIPAL INVESTIGATOR: John A. Castle \\ CONTRACT NO.: 62-9188 \\ (213) 670-1515, ext. 3606 \\ CONTRACT AMOUNT: 485,691 \\ CONTRACT DURATION: January 1981 TO \\ January 1982
}

Project Description: The purpose of this program was to first develop fully integrated PV flat panel array fields designed for optimally low life cycle costs (LCC) for the intermediate size application sector. Secondly to devise and implement modularization strategies that allow a building block approach to array field design that reflect minimal incremental cost increase over the LCC of the optimal designs.

Current Status: The designs of optimum and modularized of 20, 100, and $500 \mathrm{KW}$ array fields have been completed. A draft final report is presently being prepared.

Key Results: A low cost array field modular building block has been developed. This design represents a modularized array field increment that can without additional engineering effort be used to implement larger array fields. Desired safety, maintenance, and operational features are provided by this expandable design concept with minimum cost penalty.

$A \pm 200$ volt bipolar system was selected in lieu of a higher voltage monopolar system. This allowed the use of lower cost power components such as switch gear, MOVs, blocking diodes etc., and provides for convenient power districution, enhanced safety and sectionalization features. Results of circuit performance studies showed that use of 5 volt modules in iieu of higher voltage modules reduced life time power loss. This is a result of having additional parallel circuits of solar cells protected by a by-pass diode.

The merits of wiring PV modules in parallel horizontal rows were verified and adopted. This geometrical orientation reduces energy loss due to row to row shading and variations in diffuse radiation along the slant height of the panels. A module wiring concept was adopted where the circuits run in horizontal rows and fold back on themselves so that all input-output leads terminate in a common junction box at one end of a subarray structure. This approach eliminated the need for a return cable and minimized cable power losses. Several module to module wiring methodologies were studies. The approach finally selected uses a quick disconnect cable assembly manufactured by Amp Inc. Primary advantages are reduced installation costs while minimizing safety hazards during installation and facilitates module diagnostics and replacement. 


\title{
c. H. $\operatorname{cox}$, III
}

\author{
Massachusetts Institute of Technology \\ Lincoln Laboratory \\ Lexington, Massachusetts 02173
}

\section{ABSTRACT}

The inspections to be made, the conditions for measurement, the vartables to be measured and the analysis to be performed in order to characterize the operation of a power-conditioning subsystem (PCS) are described. Of primary concern are utility-interactive PCSs in the 2-10 kW power range intended for installation in a residential photovoltalc system and to feed a single-phase $120 / 240$ volt line.

Investigation covers four majn tasks: first and second, to identify tests and procedures for characterizing PCS technical performance. Tests in the first task are constructed and conducted under conditions near the center of the range of conditions the PCS wi.11 encounter in actual usage. The second task covers testing in the extremes of conditions, i.e., the tests and conditions are possible, though not probable. Both include tests for determining the values of parameters as well as the effectiveness of control algorithms. The principle parareters to be measured include active power flow, reactive power flow, waveform analysis, electromagnetic and acoustic noise. In the control area, tests will focus on array loading control, principle operation control and auxiliary control. The dc and ac interfaces also will be tested to characterize the effects of the PCS on them.

The third task presents procedures for estimating the probability that the PCS will meet the DOE goal: 30 years of servicable operation. Since much work remains to be done to determine just what constitutes an effective procedure for establisiling such probabilities, the material in this task is only outlined.

The fourth tasks covers a thorough examination and analysis of the PCS design, primartly in the power and control sections. The goals of this task are twofold: to uncover areas of the PCS where the design is marginal and to provide a crosscheck between predicted values and the measured values of selected parameters. Any significant descrepancies will be used to uncover areas of the PCS that rely for their operation more heavily on incidental than intentional effects.

In order to assure uniformity and to expedite measurements, tests will be conducted with the PCS connected betwicen array and utility simulators. Although the salient features of both the array and the utflity will be duplicated by the simulators, some aspects of cach will go unduplicated. Thus the final tests will operate the PCS between an actual array and utility. This will serve both as a final check on PCS performance and as a completeness check on the falthfulness of the simulacors.

The results of these tests w1ll serve several purposes. Most 1mportant, they will stand as an objective assessment of PCS performance under the full range of conditions 11 kely to be experfenced in an nctual application. As these conditions are not generally well known and require extenslve facilities to produce, most iCSs will not have been tested by thelr manufacturer. The test results will also provide the data base from which various figures of meter (FOM) can be calculated. These foNs will permit meaningful conparisons to be made between pCSs that offer different features.

\footnotetext{
"Th1s work was sponsored by the U. S. Department of Energy.

** the U. S. lovernment nssumes no responsibliley for the work presented.

+Submitted to the Third lhotovoltalc Systems and Applfentions Profect Integration Meeting,

9-11 tebruncy 2082 , N1huquerque, NM.
} 


\title{
ELECTRICAL OVERSTRESS DAMAGE IN SILICON SOLAR CELLS
}

\section{by}

MISSION RESEARCH CORPORATION

1400 San Mateo Boulevard, S.E.

Albuquerque, New Mexico 87108

\author{
Principal Investigators: Dr. V. A. J. van Lint (714) 454-3046 \\ Contract No. $\quad$ R. L. P2. Pes \\ Contract Amount: $\quad \$ 91,000$ \\ Contract Duration: October 7, 1980 - December 31, 1981
}

Project Description: In this program the effect of a simulated lightning strike near a photovoltaic array is investigated in terms of the electrical overstress damage on the silicon solar cells. A model is developed to predict the pulsed current failure level for concentrator and flat plate cells. The model predicts threshold failure current versus pulse width for a square pulse in terms of the geometrical and physical parameters of the cell. Experimental results of threshold failure current are measured for three types of concentrator cells using a double exponential pulser with a decay time of $10 \mu \mathrm{s}$. One flat plate solar cell is investigated using a square wave pulser with variable pulse width up to 100 us.

Current Status: The technical portion of the program is complete. A model for predicting threshold failure current has been developed and applied to three types of concentrator solar cells and one type of flat plate cell. Experimental measurements have been completed and comparisons made to the predicted results. Good agreement was obtained between measured and calculated results for the three concentrator cells. However, the flat plate cell exhibited an anomolously low threshold failure current. The final data analysis is being completed in preparation for writing the final report.

Key Results: Electrical overstress damage can occur in semiconductor devices as a result of a metallization melt or a silicon melt across a pn junction region. Heating from a transient current pulse occurs in the metal due to the metal resistivity and in the silicon due to the voltage drop across the junction and the bulk silicon resistivity. For the cells investigated in this study the maximum temperature rise in the silicon junction is due to heat generated in the metal fingers being conducted to the junction. The portion of the metallization pattern which undergoes the maximum temperature increase is the longest finger at a point near the bus. In order to deterinine the maximum current aensity in lite finger a comploto analysis of the pulsed current distribution had to be performed. Experimental measurements were conducted on selected concentrator cells to verify the calculations of the current distribution. Measurements were made using two microprobes, one placed on the bus and the other at various distances down the fingers. The measurements of the voltage drop down the finger agreed very well with the calculated results. Coupling the current distribution analysis with a thermal analysis of the metal fingers, a formula was developed for calculating the threshold failure current for the pn junction, assuming that the threshold failure is reached when the silicon is heated to the resistivity turnover temperature. The results for the threshold failure current are:

$$
\begin{array}{ll}
I_{T} \sim \frac{\left(A_{F T}+A_{B}\right)}{A_{F}}\left[\frac{\Delta T A_{m} C_{s} W_{f} \sqrt{D}}{\rho_{m} \sqrt{\tau}}\right]^{1 / 2} & \text { for } \sqrt{D_{T} \leq W_{f}} \\
I_{T} \sim \frac{.47\left(A_{F T}+A_{B}\right)}{A_{F}}\left[\frac{\pi \Delta T A_{m} C_{s} D}{\rho_{m} \ln \left(\frac{\sqrt{D_{T}}}{W_{f} / 2}\right)}\right]^{1 / 2} & \text { for } \sqrt{D_{T}}>W_{f}
\end{array}
$$


where $A_{F}$ is the total effective area of current flow from the fingers, AB the bus area, Af the effective area of current flow from one finger, Am the finger. cross sectional area, $\mathrm{Pm}_{\mathrm{m}}$ the silver resistivity, $C_{s}$ the silicon heat capacity, D the silicon thermal diffusivity, Wf the finger width, and $\tau$ the pulse width of the current pulse. Using these equations the threshold failure current was calculated for each of 4 cell types as a function of pulse width in the range of 1 us to $1 \mathrm{~ms}$.

The three concentrator cells that were modeled and experimentally measured for overstress failure were a $2 \mathrm{~cm} \times 2 \mathrm{~cm}$ ASEC cell, a $2 \mathrm{~cm} \times 2 \mathrm{~cm}$ Sandia Labs cell and a $2.5 \mathrm{~cm} \times 6 \mathrm{~cm}$ Solarex cell. All concentrator cells were .3-.4 $\Omega-c m$ base silicon and used silver metallization. The failure testing was performed with a Maxwell Labs $150 \mathrm{kV}, 50 \Omega$ pulser which was transformer coupled to . $1 \Omega$. The transformer, built by the Air Force Weapons Laboratory, weighed over one ton when completed. With the transformer, the pulser was capable of delivering a double exponential pulse with a decay tine of $10 \mu \mathrm{s}$ and a short circuit current in excess of 30,000 A. The results of the reverse biased thresliold failure tests are given in Table I along with results predicted for a $10 \mu \mathrm{s}$ square wave from the equation given above.

Table I. Comparison of Predicted and Measured Reverse Biased Threshold Failure Current at 10 us for Three Concentrator Cells.

Cell Type

Sample size

Measured threshold failure current

(ave. \pm 1 o)

Predicted threshold failure current

Ratio (ave. measured to predicted)

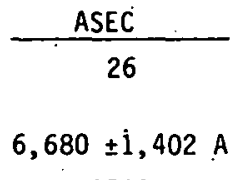

$3700 \mathrm{~A}$

1.81

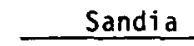

14

$$
3,235 \pm 853 \mathrm{~A}
$$

$3500 \mathrm{~A}$

.92

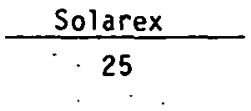

$18 ; 400 \pm 5,660 \mathrm{~A}$

$12,800 \mathrm{~A}$

1.44

The model, based solely on physical parameters, predicts the failure threshold within a factor of two. The measured results for forward biased threshold failure current were from $25 \%$ to $100 \%$ higher than the reversed biased results.

The one flat plate cell tested was a $10 \Omega-\mathrm{cm}$ cell, $2 \mathrm{~cm} \times 2 \mathrm{~cm}$ obtained from Photowatt. This cell was measured for overstress failure using a Velonix 360 pulser with a $12 \Omega$ transformer. At $100 \mu \mathrm{s}$ the failure current for reverse bias was 3-5 A. This compares to a predicted failure current of $175 \mathrm{~A}$. The forward biased failure current was $820 \pm 80 \mathrm{~A}$ at $10 \mu \mathrm{s}$ and $400 \pm 50 \mathrm{~A}$ at $100 \mu \mathrm{s}$. This anomolously low failure current for a reversed biased high resistivity pn junction has been observed in rectifiers.

The reason for the low failure current is presently not known. Such low failure currents in high resistivity celis could have a major impact for lightning effects in large arrays. A recommended program to investigate this phenomena should include a modeling effort to understand the anomolous behavior. 
DOE PHOTOVOLTAIC GRANT PROJECTS

Mississippi County Community College
Blytheville, Arkansas 72315
Northwest Mississippi Junior College
Senatobia, Mississippi 38668

Georgetown University

Washington, D.C. 20007

\author{
Technical Assistance Coordinator: Stephen I. Kaplan \\ Oak Ridge National Laboratory \\ (615) $574-5819$
}

Contract Data: not applicable

Project Description: These grants were awarded to provide advanced, primarily photovoltaic (PV) solar energy systems that would explore problems especially pertinent to institutions of higher education, and would provide erection and operating experience useful to other emerging solar PV system concepts.

Current Status: The Mississippi County Community College (MCCC) system is presently undergoing post-startup testing. The Northwest Mississippi Junior College system is partially erected and the project is currently suspended. Georgetown University has erected the building that will support its rooftop PV system and has issued a RFP to design and install the system.

Key Results: MCCC is now at a stage where pertinent and valuable results are emerging concerning system design and applications. Structural stability of reflector components and maintenance of high reflectivity are key design requirements. 


\title{
ANALYSIS OF LOW ENERGY DENSITY PHOTOVOLTAIC APPLICATIONS
}

\author{
by \\ Research Triangle Institute \\ Research Triangle Park, \\ North Carolina 27709
}

Contract No. :

Principal Investigator:

Contract Amount:

Contract Duration:
$62-8255$

C. D. Parker

$\$ 176,190$

December 8, 1980

March 31, 1982

The purpose of this project is to identify and rank low energy density photovoltaic applications and to do detailed analyses and tradeoff studies of the best applications. Low energy density applications are those with peak demands of about $60 \mathrm{~W}_{\mathrm{p}} / \mathrm{m}^{2}$. The approach has been to use available energy-use and building inventory data bases to rank potential low energy density applications. From this ranking, four building types were selected and a detailed analysis and trade-off study of these applications is currently underway.

Building types selected for further analysis and their estimated average daily demand densities are a distributor warehouse $\left(12 \mathrm{w}_{\mathrm{p}} / \mathrm{m}^{2}\right)$, an auto repair center $\left(15 w_{p} / m^{2}\right)$, a day care center $\left(42 w_{p} / m^{2}\right)$, and a branch bank $\left(63 w_{p} / m^{2}\right)$. Estimated average annual energy densities for these buildings are 50, 75, 124, and $188 \mathrm{kWh} / \mathrm{m}^{2}$, respectively. Each of these building types is being analyzed in four locations, i.e., Madison, WI (NE); Charleston, SC (SE); Phoenix, AZ (SW); and Salt Lake City, UT (NW).

To accomplish the analysis, representative buildings have been designed and simulated using the DOE-2.1 computer program. These simulations and TRY weather data have been used to generate the hourly energy demand for. the 16 applications/site pairs. The TRY data has also been used to generate compatible ilisulatioii dala.

SOLCEL II has been modified to accommodate both seasonal and time-of-day energy rates and is currently being used to analyze the 16 application/site pairs. Inputs to the SOLCEL II program include the hourly loads data and solar insolation data generated with DOE-2.1. The analysis issues include flat plate and concentrator arrays, PV system component costs, energy storage, and rate structures. 
135 KW PHOTOVOLTAIC SYSTEM

FOR THE OKLAHOMA CENTER FOR SCIENCE \& ARTS

\title{
BY
}

\author{
SCIENCE APPLICATIONS, INC. \\ 1710 GOODRIDGE DRIVE \\ MCLEAN, VIRGINIA 22102
}

\author{
PROJECT MANAGER: DR. YUDI P. GUPTA \\ (703) 827-4783 \\ CONTRACT NUMBER: DE-ACO4-79ET20630 \\ CONTRACT AMOUNT: 2.9 MILLION \\ CONTRACT DURATION: 30 SEPTEMBER 1980 TO \\ 01 MARCH 1982
}

Project Description: The system includes a fixed, flat plate array with reflector augmentation interfaced to the facility bus thru a PCU with a $480 \mathrm{~V} 30$ output. The array is mounted on an essentially flat roof. The modules are unique; they are $9 \mathrm{ft} .2$, and have a 12 -series by 6 parallel configuration of $10 \times 10 \mathrm{~cm}$ square polycrystalline silicon cells. There is $100 \%$ parallelism in the cell interconnections to maintain efficiency during the periods when the reflector illimination is non-uniform. This feature also greatly reduces the adverse effects of single cell failures. There are 18 branch circuits, each with 84 modules in series. A total of 1512 modules are installed. The reflectors are laminated glass minors. The reflector panels extend beyond the module rows to minimize end effects during morning and evening. The PCU is a Windworks inverter with a $420 \mathrm{~V} A C$ output and a step-up transformer which also provides DC isolation from the facility $480 \mathrm{~V}$ AC bus.

Current Status: Installation was completed in January 1982 and the system is undergoing test and evaluation. At this time of year there is no reflector augmentation and peak power output is limited to the $107 \mathrm{KW}$ produced by the bare modules. During the summer months the output will increase to $135 \mathrm{KWp}$. The facility 'is on the fringe of a high intensity hail area. The module superstrates are $3 / 16^{\prime \prime}(4.8 \mathrm{~mm})$ high strength tempered glass. During installation, the modules surrived a severe hailstorm with stones up to $1 \frac{1}{2}$ " (38mm) diameter.

Key results: It currently appear.s that all objectives will be met. Verification of performance under non-uniform reflector augmentation must await an increase in the solar declination. 


\title{
A 100 KILOWATT SOLAR PHOTOVOLTAIC FLAT PANEL POWER SYSTEM FOR THE BEVERLY HIGH SCHOOL, BEVERLY, MASSACHUSETTS
}

by

Solar Power Corporation Woburn, MA 01801

\author{
Program Manager: R.R. Addiss, Jr. \\ (617) $935-4600$ \\ Contract No.: DE-AC04-79ET20631 \\ Contract Amount: $\$ 3,146,429$ \\ Contract Duration: October 1979 to \\ December 1983
}

\begin{abstract}
Project Description: The purpose of this project is to install; and operate and evaluate for a two year period, a $100 \mathrm{~kW}$ solar electric generating station at the Beverly High School. The array is located on a hillside behind the school, and supplies power directly to the school by interconnection with the $4160 \mathrm{~V}$ main utility feed line in the school. Any excess energy produced is sold to the utility. The array field is divided into two independent $50 \mathrm{~kW}$ subfields, each having its own $60 \mathrm{~kW}$ inverter. The project is a cooperative effort between Solar Power Corporation, Stone \& Webster Engineering Corporation, the New England Electri.c. System, and the Beverly Public School System.
\end{abstract}

Current Status: System installation was completed in February, 1981, when the system was first energized. Following a two month period of checkout and debugging, and a one month period to verify operation, the system became operational. All tasks associated with this phase of the project have been completed except for finishing the Operation and Maintenance Manual and writing the final report. The final phạsc, a two year pertod of operation and evaluation, began on December 1 , 1981 and is presently on schedule.

Key Results: Except for a defective circuit which developed early in one of the two $60 \mathrm{~kW}$ inverters, resulting in an outage of one subfield unt11 repairs could be effected, the system has operated up to design expectations. Total AC energy produced was $53.44 \mathrm{MWh}$ as of December $14 \mathrm{th}$, of which $2.40 \mathrm{MWh}$ was sold to the utility. Analysis of system performance to date shows that total output is below expectations only because total operating hours are low. This in turn has result.ed from ground fault tripouts of the inverters caused by spurious ground current pulses of unknown origin rather than by true ground leakage currents. As a safety feature, the inverters are designed to shut down automatically when ground leakage currents exceed a preset level (presently $18 \mathrm{~mA}$ ). Manual reset is required; and several days may go by before site personnel become aware that a tripout has occurred. This loss of system operation cannot be tolerated, and changes in trip circuit operation to circumvent tripouts from spurious pulses are under investigation.

A similar problem has plagued the collection of data by the computer controlled on-site data acquisition system (ODAS). Errors in execution of computer commands 
have occurred, causing the ODAS to hang up until manual restart is effected. Again, many days may pass before the problem is noticed and corrected. During this time no data is being collected. This problem improved dramatically after hardware repairs were made and software modifications were introduced in october. 


\title{
PHOTOVOLTAIC POWER PROCESSING UNIT FOR \\ LINE INTERFACE USING $20 \mathrm{kHz}$ PWM TECHNIQUES
}

\author{
by \\ TESLACo - Optimum Power Conversion \\ 490 S. Rosemead Blvd., Suite 6 \\ Pasadena, CA 91107 \\ Principal Investigators: Slobodan Cuk \\ Alan Cocconi \\ (213) 795-1699 \\ Contract No.: 74-5898 \\ Contract Amount: $\$ 162,000$ \\ Contract Duration: July 1, 1981 to \\ July 1,1982
}

Project Description: To design and build a prototype photovoltaic power conditioning unit (PCV) at a suitable modular power level for residential size (7.5kWp) which interfaces to a utility grid.

Status of Development: The optimum size of the PCV was determined to be at the high power level of $4 \mathrm{~kW}$. Scaling laws of magnetics design lead to more efficient and cost effective designs at higher power level. Size and weight consideration (with ultimate cost benefits) prompted a choice of $20 \mathrm{kHz}$ PWM (pulse width modulated) techniques. The cost consideration led to a choice of the simplest possible topology which would still include high-frequency $\mathrm{dc}$ isolation. A single quadrant dc isolated push-pull buck converter switching at $20 \mathrm{kHz}$ is used to generate a full wave rectified sine wave which is subsequently unfolded by a low speed four transistor bridge to result in $60 \mathrm{~Hz}$ sine wave power output.

The breadboard is now operational at the full power objective of $4 \mathrm{~kW}$ ( $\mathrm{rms}$ ).

A control strategy has been developed which allows direct interface to the utility grid. It has already been tested at $30 \%$ of the full power. The maximum power tracking circuitry has yet to be developed and protection features tested under all possible fault conditions.

Key Results: It has been demonstrated that this approach leads to a simple and effective Tine interface. Both the low cost and small size/weight are the important benefits of this approach. The crossover distortion resulting from the unfolding stage occurs at zero or low current levels, with negligible consequences for the power output to utility interrace. 


\section{PHOTOVOLTAIC RESIDENTIAL RETROFITS}

by

Total Environmental Action, Inc.

7 Church $\mathrm{Hill}$

Harrisville, New Hampshire 03450

$\begin{array}{ll}\text { Contract No. } & 62-0229 \\ \text { Principal Investigator } & \begin{array}{l}\text { D.E. Mahone } \\ (603) 827-3374\end{array} \\ \text { Subcontractor: } & \text { Tri-Solar Corp. } \\ & \text { A.R. Millner } \\ & (617) 275-1200 \\ \text { Contract Amount: } & \$ 239,440 \\ \text { Contract Duration: } & \text { August, } 1980 \\ & \text { January, } 1982\end{array}$

Project objective: One of the largest potential markets for photovoltaic power systems is the retrofit market for residences. It is also one of the most difficult to characterize, because of the diversity of housing types, construction techniques, and site conditions. In addition, many PV system design and installation details for retrofit applications must be studied and solved. The goal of this study is to provide a comprehensive analysis of the potentials and problems of retrofitting PV power systems into the American housing stock.

Project Description: The first of three Tasks identifies characteristics of typical new and existing residences in the northeast, southeast and southwest regions of the United States. The study uses published data and reports, such as the housing census and energy reviews, to generate gross numbers of different housing types by region, age of building, construction, income group, etc. Summaries of other physizal characteristics, such as building orientation, roof pitch, roofing material, ana availability of utility spaces in buildings are compiled from existing studies and correlated (so far as possible) with the gross numbers. The result of Task $\mathbf{l}$ is an estimate of the total retrofit potential for PV systems in the U.S.

In Task 2, typical, specific housing designs are selected to represent new and existing single and multi-family residences in the three regions under study. The selection of these designs is illfiuenced by information determined in Task 1. 
PV system components are selected for these buildings, including collector arrays, mounting hardware, power conditioning equipment, and system wiring. Components are selected and developed as generic designs from among available or nearly available (by 1986), state-of-the-art products.

In Task 3, system design and installation details are worked out for the typical building retrofits to provide detailed and accurate estimates of installation costs. Constraints imposed by building and electrical codes, construction practices, and levels of trade:skills are acknowledged. Knowing the number of potential rooftops and the size, cost, and potential electrical output from residential PV installations, the market penetration potential is assessed, and the economic feasibility of residential PV systems is analyzed. Costs over the life-cycle of the PV system are compared, to the electrical costs without photovoltaic power. Using this method, a Iife-cycle cost ratio (LCCR) is calculated using the range of estimated systen costs and the economic conditions from 10 Solar Economic Regions of the U.S. The assessment of power production potential uses roof area and weather data from these regions. As a final activity, potential barriers to residential pV retrofits and possible incentive programs for encouraging widespread acceptance of PV retrofits are discussed.

Current Status: Technical work on the project was completed in November, 1981. The draft final report is under review, and the final document will be published in early spring, 1982 .

Key Results: 1) There are approximately 60 million residential structures in the U.S. Of these, $35 \%$ (21. million) are candidates for photovoltaic retrofits.

2) The national potential for cost effective residential PV retro-

fits is enormous: $o^{-}$There are 9.47 billion square feet $\left(879.8 \times 10^{6} \mathrm{~m}^{2}\right)$ of suitable rooftop.

- This area could accept $92.2 \times 10^{6}$ peak kilowatts of installed PV capacity.

- This could produce $142.5 \times 10^{6}$ megawatthours per year of electricity.

- This is equal to nearly $20 \%$ of the electricity used for residential purposes in 1980 .

3) The recommended residential module will be approximately $4^{\prime} \times 6^{\prime}$, and will be entirely series wired internally. to produce a nominal 100 volt cutput.

4) Residential retrofit arrays will be in the 4-8 $\mathrm{kW}_{\mathrm{p}}$ size range. Assuming the recommended 4' $4^{\prime} 6^{\prime}$ module, each array will employ between 8-16 modules.

5) Total system costs will range from $\$ 2.00$ - $\$ 2.81$ per peak watt.

6) Mounting systems for rooftop arrays must be very well designed to achleve market acceptance. Mounting system costs will account for 15\%-35\% of total system cost. 
7) Cost estimates for a $4 \mathrm{~kW}_{\mathrm{p}}$ retrofit array indicate a range of $\$ 8300$ - $\$ 11,300$ for total installed cost. The least experisive is a simple Standoff design, the most is a Rack mount.

8) The major present barrier to acceptance of photovoltaics for residential applications remains the high cost of systems. If the DOE 1986 Cost Goals are met, however, the systems will become cost effective (on a life-cycle cost basis) in many regions of the country. With a $20 \%$ tax credit, they will be cost-effective everywhere but the Northwest. The high first cost of the systems requires acceptable financing mechanisms for the homeowner. 


\title{
INVESTIGATION OF A FAMILY OF POWER CONDITIONERS \\ INTEGRATED INTO THE UTILITY GRID
}

\author{
by \\ UNITED TECHNOLOGIES CORPORATION \\ South Windsor, Connecticut 06074 \\ Principal Investigators: F. J. Kornbrust \\ J. R. Vivirito \\ J. M. King, (203) 727-2210 \\ Contract No.: $\quad$ DE-AC02-79ET29355 \\ Contract Amount: $\$ 288,953$ \\ Contract Duration: September 1, 1979 to \\ A.pril 30,1981
}

Project Description: The objective of the contract was to define advanced power conditioners for residential and intermediate-size applications which provide improved interface and economic characteristics for use with solar photovoltaic and other advanced $d c$ sources.

Current Status: The contract is complete. A topical report on the $10 \mathrm{~kW}$ unit for residential has been issued by Sandia (SAND81-7016). A final report manuscript has been provided to Sandia.

Key Results: Conceptual designs were prepared for $10 \mathrm{~kW}$ and $80 \mathrm{~kW}$ power conditioners. Both designs utilize' transistors as switching elements and a pulse-width modulated switching pattern to meet output power quality requirements. The control logic for each unit is based on 8-bit microcomputers. Both dc and ac switchgear and sensing equipment is located within the power conditioner enclosure.

Commonality of the power circuit and logic between the units reduces development and product support requirements. Both units meet or better DOE goals for efficiency and mature production cost and are estimated to provide significant reductions in the power conditioner contribution to solar photovoltaic power cost compared to currently available equipment. 
PHOTOVOLTAIC ENERGY SCENARIO STUDY

by

General Electric Company

1 River Road

Schenectady, New York 12345

$\begin{array}{ll}\text { Contract No. } & 13-9482 . \\ \text { Principal Investigator: } & \text { G.J. Bonk } \\ & (518) 385-4097 \\ \text { Contract Amount: } & \$ 401,640 \\ \text { Contract Duration: } & \text { April 7, 1980- } \\ & \text { July 15, 1981 }\end{array}$

The main object of this study was to show the essential economic information upon which potential residential, commercial or industrial users of solar photovoltaic electrical generating equipment might base investment decisions. T The users were generalized on a geographic region basis and were not considered as individuals. A major aspect of this work was centered on the "What If?" impacts on the results due to various potential changes in the assumed study conditions.

The work which was broken into three major areas, is now technically complete. $\%$

\section{Task I Candidate PV Systems}

After searching, defining, and screening of a large selection of potential systems, four PV systems wère sélected:

a. Residential - A roof mounted, fixed tilt, flat plate device; "Direct Mount".

b. Intermediate 1 - Fixed tilt, flat plate; "Flat Plate".

c. Intermediate 2 - Parabolic trough, actively cooled on carousel structure; "Line Focus".

d. Intermediate 3 - Fresnel, passively cooled on a pedestal structure; "Point Focus".

Each system has been fully characterized, in terms of operational variables, such that it can be utilized in the Optimized Generation Planning (OGP) computer program.

\section{Task II Utility Energy Scenarios}

General Electric's OGP program has been used to model nine regions of the US for PV impact on Electrical Generating Systems operation and investment costs. After defining a baseline or reference set of conditions for each region (and thus the whole country), the reference case OGP calculation was performed. Issues concerning capacity displacement and unit maintenance effects were met and resolved.

With the agreement of the study review board, a set of alternate scenario definitions was prepared. This determined the input values to be used during the. Utility Economics part of Task III. 
Task III Interrelationship of PV Systems and Energy Scenarios

Before the main body of OGP calculations were made, an integration of the PV performance model adaptation work with the PV systems characterization data was made. Utility savings were converted to PV user savings using a unique Utility Rate structure model and fed to the User Economics model. The Results Interrelationship sub-task was accomplished using original graphic representations.

Results

1. Displacement of utility load by PV devices leads to higher value potential in regions with initial heavy oil usage, low load growth rate, and high insolation level. WSCC-south is the region with the most attractive utility economics.

2. The most important Energy Supply scenario effects come from changes in assumptions concerning oil prices and oil usage.

3. Utility "avoided cost" values must be fed through the utility rate structure as user incremental cost rates to make user owned PV systems economic. Utility "average cost" feed through is not sufficient.

Current Status

A draft report has been submitted and is now in the review and final re-draft process. 
DISTRIBUTION :

SERI, Library (2)

1536 Colle Blvd. Bldg. \#4

Golden, CO 80401

M. Prince (6)

Chief, Photovoltaics Branch

Department of Energy

Room 5B066 Forrestal Building

1000 Independence Avenue SW

Washington, DC 20585

J. A. Morley

Director, Solar Energy Division

Albuquerque Operations Office

Department of Energy

Albuquerque, NM . 87115

4723 G. J. Jones (250)

3141 T. L. Werne.r (5)

3151 W. L. Garner (3)

For DOE/TIC (Unlimited Release)

8266 E. A. Aas

DOE/TIC . (25)

(3154-3 R. P. Campbell)

b 
-

(
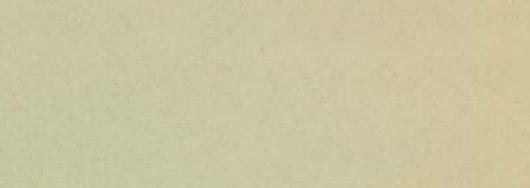

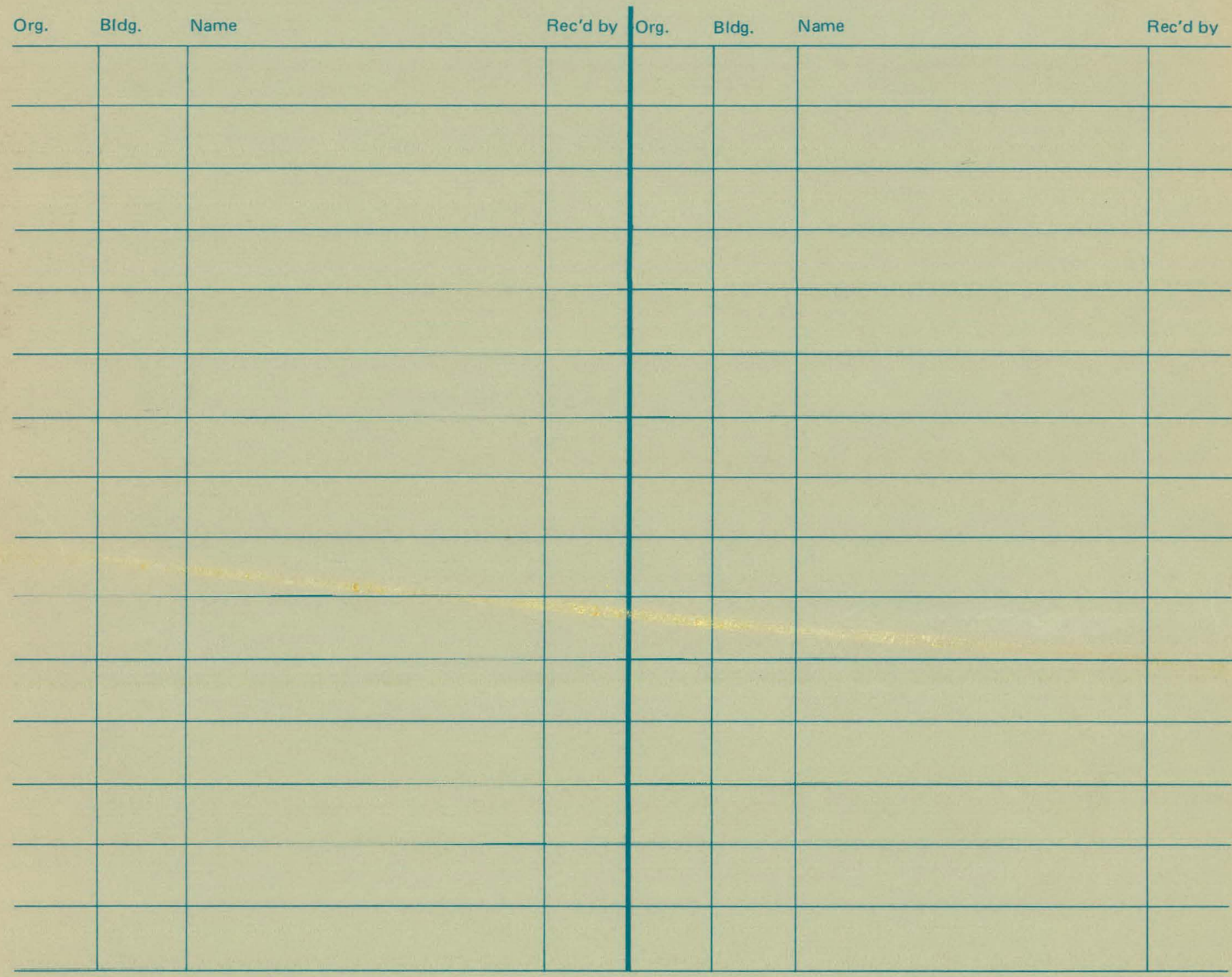

